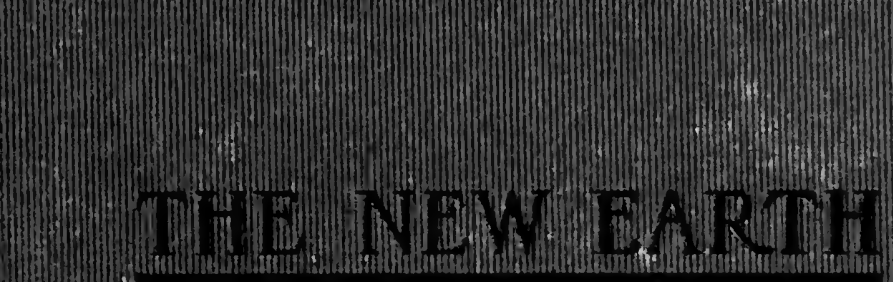

3. 5 HARWoOd

in

singin's

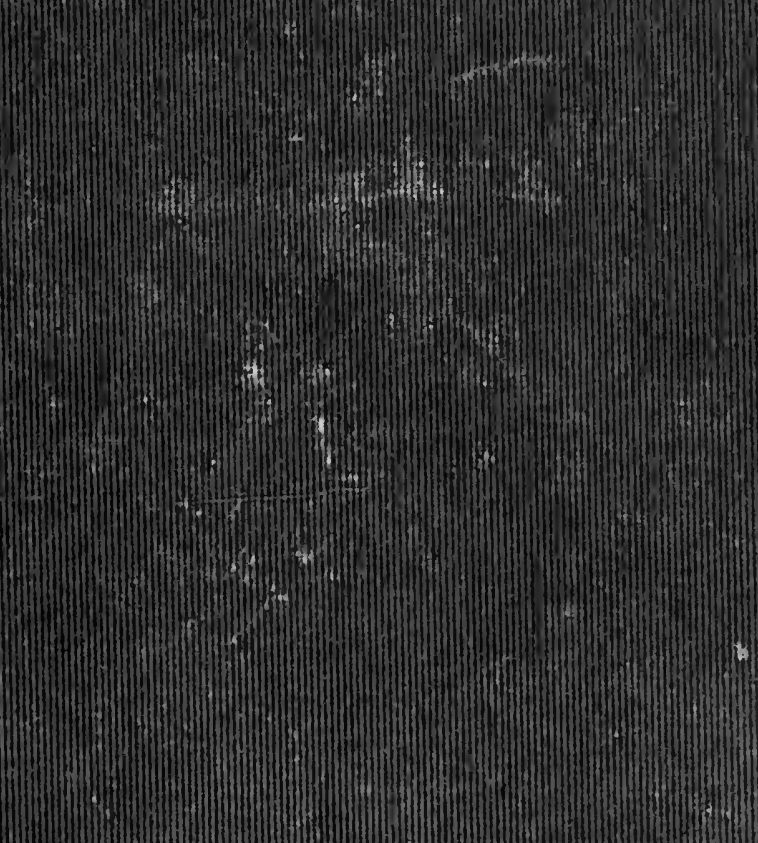




\section{Digitized by the Internet Archive in 2007 with funding from Microsoft Corporation}




\section{USIVERSTTY of CALIFORNL AT \\ LOS ANCELES \\ LIBR.ARY}




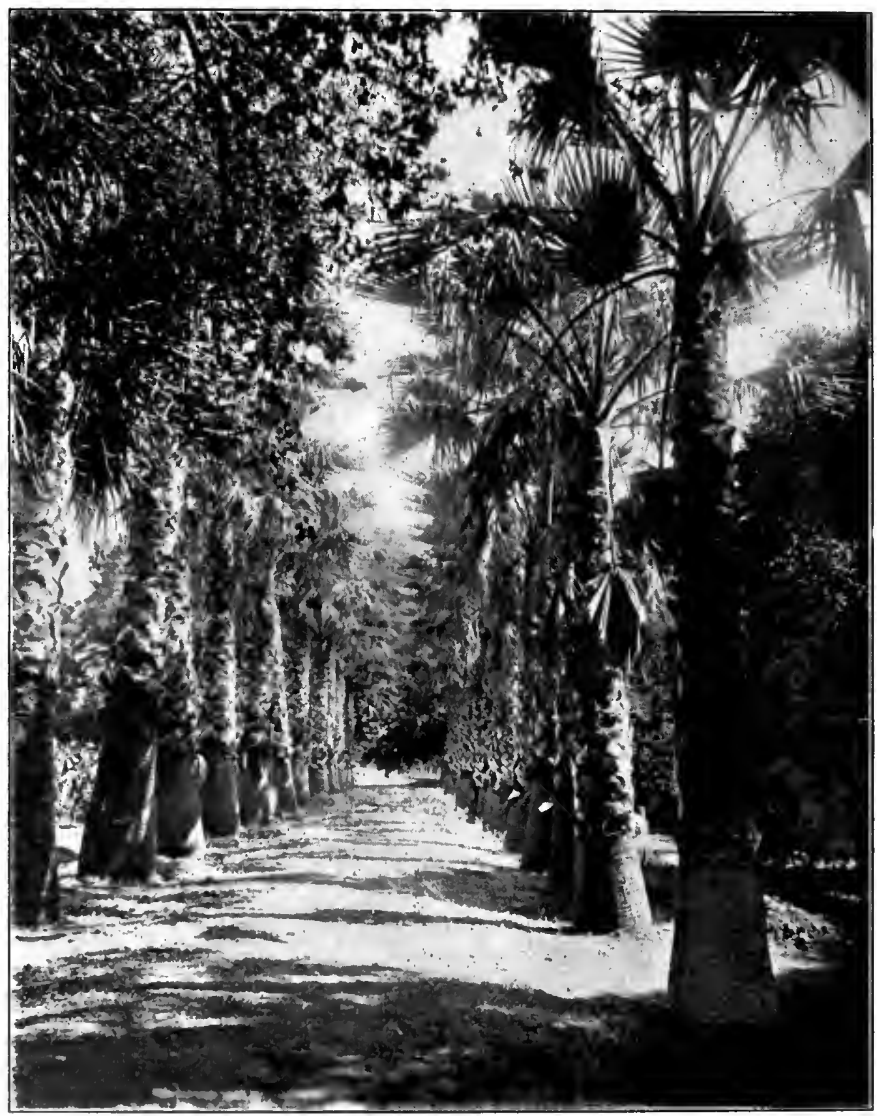

In the land of the palms, a California scene 


\title{
THE NEW EARTH
}

A RECITAL OF THE

'TRIUMPHS OF MODERN AGRICULTURE

IN AMERICA

\author{
BY \\ W. S. HAR WOOD
}

AUTHOR OF " NEW CREATIONS IN PIANT LIFE"

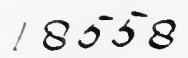

WITII MANY ILLUSTRATIONS

Inetw 具ork

THE MACMILLAN COMPANY

LONDON: MACMILLAN \& CO., LTD.

1906

All rights reserved
10558
Sept. 1909 


\section{Copyright, 1906 \\ By The Macmillan Company}

Set up and electrotyped. Published, May, 1900

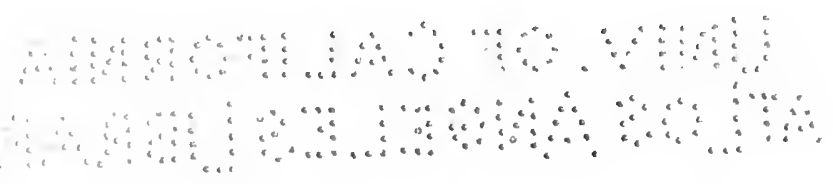

mount Pleasant Press

J. Horace McFarland Company

Harrisburg, Pa. 


\section{$S_{521}$ \\ $\mathrm{H} 26 x$ cop.z}

\section{PREFACE}

NOW and then, out of those explorations 1 which scientific men of the severer type make into the realm of the unknown, there may come something of direct practical aid to the race, something that makes the world move a little more easily in its grooves; though very many of the discoveries are of scientific value alone, of interest chiefly to isolated circles of great specialists.

There is another class of scientists, not large but steadily growing, whose work in the rarious bureaus of the Department of Agriculture in Washington, and, preëminently on the staffs of the Experiment Stations of the United States, is not only admirably scientific in character and scope, but of commanding economic importance. In the preparation of this volume, the writer has been under obligation to this 


\section{PREFACE}

latter class of men, both in the way of information derived from their publications and in the way of verification of facts. 'These men are not only bringing distinction to their states, and, through their discoveries, adding enormously to the national wealth, but they are conspicuous examples of a fine and rich unselfishness.

'The New Earth is not a fanciful, unreal place; for, though it has many curious mysteries, some yet far from solution, and though it is now and then shrouded in fascinating mists, it is a tremendously practical realm, in many ways, as I hope may develop in the pages to follow, the most commanding in its practical influence of any realm or any era in history.

W. S. H. 


\section{TABLE OF CONTENTS}

I. The Old and the New . . . 1

II. The Brain of the Earth . . . 7

III. Soil Inoculation . . . . . 27

IV. Breeding New Grains . . . 48

V. Plant Development . . . . 65

VI. 'The Enemies of Plant-life . . 83

VII. The Weeds of the Earth . . . 103

VIII. Luther Burbank . . . . 117

IX. Horticultural Progress . . . 129

X. Modern Forestry . . . . 143

XI. Modern Dairving . . . . 182

XII. Animal Husbandry . . . . . 20\%

XIII. Reclaiming the Earth . . . 232

XIV. The Foods of the New Earth . . 252

XV. Coöperation . . . . . . 285 


\section{TABLE OF CONTENTS}

CHAPTER

PAGE

XVI. The Selling of the Surplus . . 298

XVII. The Experiment Stations . . . 319

XVIII. Agricultural Education . . . 335

XIX. National Aid . . . . . . . 351

XX. The Importance of the Farm . . 365 


\section{LIST OF ILLUSTRATIONS}

In the land of the palms, a California scene Frontispiece

Five acres of one of the famous new wheats produced at the Minnesota Station, the yield being much above that of the old wheats . . . . . . 5

Microscopic photograph of soil of great fertility . . 12

Microscopic photograph of a soil having no fertility, abso-

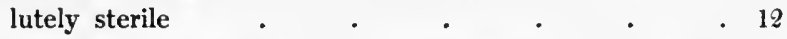

A striking illustration of soil inoculation. The pots contain clover. The first one, at the left, has not been treated in any way; the next has no nitrogen; the next no nitrogen, but inoculated with bacteria; the next no phosphorus; the next no potassium; the last has been fed nothing. . . . . . 21

Showing length of head of a new wheat. It has been bred not only for size but for disease-resistance and

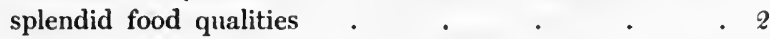

Planting-machine for seeds, so made that absolute accuracy is secured . . . . . . . 37

The group of wheat to the left shows one hundred average heads from a sample bought for experiment. To the right, the same number of heads grown from large kernels from medium heads

To the left, wheat grown from large kernels. small heads; to the right, wheat grown from large kernels from large heads, illustrating selection . $\quad . \quad$. 53 


\section{LIST OF ILLUSTRATIONS}

Fertilizing tests with lettuce. No. 1, no fertilizer; No. 2, with potash; No. 3, potash and nitrogen; No. 4, potash and phosphoric acid; No. 5, potash, nitrogen and phosphoric acid $\quad . \quad 6 \quad . \quad 60$

Field of corn bred to produce a high percentage of fat, or oil . 69

Covering new wheats in the nursery to protect them from sparrows and the weather. $\quad . \quad . \quad .76$

Potato spraying experiments at the Cornell, New York, Station. Gain due to spraying, 233 bushels per acre .85

Planting new wheats by hand, a kernel at a time, in their earlier years when but very few kernels exist . . 92

Prof. W. M. Hays, now Assistant Secretary of Agriculture, lecturing on weeds to a class at the Minnesota State School of Agriculture

Making field notes on a new wheat. Every incident in the life-history of the new wheat is recorded with the utmost eare

Sieves used in testing and cleaning new wheats, with scales and record book

Chateau on the Vilmorin estate, near Paris, home of a long line of famous seedsmen . $\quad . \quad$. $\quad . \quad$. 124

Searching for the peach root-borer . . . . 133

$\Lambda$ lesson in winter pruning . . . . . 140

Date-palm tree, $6 \frac{1}{2}$ years old, at Tueson. It was grown from a sucker. It is bearing its third crop of fruit, about 100 pounds . . . . . . 149

When the plums are ripe in California . . 156

When the California vineyards are heavy with the harvest. 16.5

Windbreak and hedge of soft maples in a prairie region where forestry is being taken up 


\section{LIST OF ILLUSTRATIONS}

A feature of the coastwise trade of the Pacific-rafting logs by sea

Shelter-belt of young Norway pine in North Dakota, illustrating practical forestry in a prairie region

Grove of the Sequoia gigantea grown in California to show that this noble tree is worthy of cultivation. The progenitors of these trees, now growing in California, are over five thousand years old

At a beet-sugar factory in Minnesota $\quad . \quad \because 204$

Dr. S. M. Babcock, inventor of the Babcock test . 213

Winter school in stock-judging at Iowa Agricultural College 220

Cutting sugar-cane in Louisiana, near New Orleans

Prime steers raised at the Louisiana Station. They were immunized from Texas fever and fed on black molasses, rice bran, cottonseed meal and lespedeza hay. They topped the Chicago market on sale . $\quad$. 236

Lambs fattened at the Wyoming Station on alfalfa and native hay. Students are also given object-lessons in dressing animals in an attractive manner

This wheat, in California, is growing upon soil crusted with white alkali, originally a barren desert, but reclaimed by a proper cultivation of the soil

Showing root system of the Australian salt-bush plant, a fine stock food. It grows on desert lands, the roots boring down through the hard-pan frequently five feet for moisture

Distribution flume of a Montana irrigation system .

Opening a branch of the Truckee-Carson system in the national irrigation project, June 17, 1905 


\section{LIST OF ILLUSTRATIONS}

Respiration calorimeter at the Storrs, Connecticut, Station.

The man undergoing test as to food values lives in the respiration chamber, the square box to the left of the chair, from five to eight days . $\quad . \quad$. $\quad .284$

Grinding corn under test at the Illinois Station preparatory to laboratory tests to show the exact food value of the corn

Illustrating the chief constituents of 100 ounces of ordinary corn. The smallest bottle contains the ash, 1.45 per cent; next the oil, 1.70; next fiber, 2.60 ; next protein, 10.92; next carbohydrates, 80.35 ; last the entire corn

In the library of the first coöperative society in the worldthe Pioneer, of Rochdale, England

Corn-harvesting in Tennessee. . 316

Looking down Market street in San Francisco toward the bay-the docks lie to the right and left of the ferry building at the end of the street.

Loading flour at Seattle for shipment to Chinese ports . 332 Flour on the Atlantic seaboard awaiting foreign shipment . 341

Along the docks in New Orleans when the cotton is moving 348 Dock scene in San Francisco.

Looking down upon an extensive series of experiments at the Cornell, New York, Station .

General scheme of a California substation, with irrigation reservoir in the foreground 


\section{THE NEW EARTH}

CHAP'TER I

18558

THE OLD AND THE NEW

D

UST-BLOWN and blizzard-swept, with a lean, weed-grown soil on which scrawny kine and stunted crops were raised, the old Earth was far from paradise. The cheerless, desolate home, often untidy and usually cursed with food unfit to eat, the ever-growing mountain of debt, the deadening isolation, the lack of opportunity for cultivation, the steadily growing dislike of it all, not infrequently deepening into hate,- - these were the things of the Old Earth.

The New Earth is rising out of the Old, -a fine sane resurrection. Broad acres, well kept and well stocked; splendidly equipped buildings; a modern home with its good cheer, its books, its music, its culture; a close touch with progress; a balance in the bank; the pride of strong men and sensible women 


\section{THE NEW EARTH}

in a calling as old as the human race, but never until now come into its own,- - these are the tokens of the New Earth.

Very many of the details of the progress of the New Eaith, as well as many of the underlying principies of this progress, are seen by those most vitally concerned through vague mists, while the millions of the nations, whose very existence is dependent upon the tiller of the soil, know next to nothing of all the marvelous doings of the generation just closed. It is to set forth some of the great changes which have been wrought that this volume has been undertaken.

In a sense more vital to the race than he himself knows, the tiller of the soil has become the protector of the nation-the one who, in a very near and positive way, keeps the nation in the physical poise essential to the best thought and fiber of the race. Not only does he feed and clothe the race, but he maintains the arable globe in a condition of constant service: without his hand, the earth were given over to the wilderness and its beasts. It is a colossal undertaking which is ever before him,- the care of the nations. 


\section{THE OLD AND THE NEW}

It calls for his noblest efforts. It enlists the highest and best of his nature. It has not infrequently reacted upon himself, leaving him poor in purse and lean in hope. $\mathrm{He}$ is the feeder of the race, and, if he fails to do his full duty, the race deteriorates.

It should naturally follow that so important a person should not only have the friendship of the race, but all that fine and constant sympathy which true friendship assures. Quite the contrary has been the case. Until these later days he was frequently of all men most miserable; neglected, looked down upon; servant where he should have been master; poor and becoming poorer; the prey of sharpers; the disconsolate follower of a calling which, seen in its true perspective, is outranked by no other in power, scope, or service to mankind.

In the midst of this sad predicament science came to his help,- - that sensible science of our advancing day, which has for its ultimate end not merely discovery, but application; which is not so delighted with the formulating of a new law as it is ovcrjoyed at the lifting of a burden.

Then began that remarkable series of agricultural demonstrations which are among the 


\section{THE NEW EARTH}

signal achievements of the last quarter of the century which has just closed; a series, indeed, the limit of whose influence is beyond the scope of the imagination. Greater practical progress in all departments of life dependent upon the soil has been made in fifty years than in fifty previous centuries.

Today the advanced farmer, gardener, dairyman, horticulturist or stock-breeder,-with that steadily increasing number of men of means who are turning back to the earth as the source, after all, of the highest happiness,-is looking more and more eagerly for the aid which practical science offers in the solution of the problems of the New Earth. The old-time farmer still exists, often clinging to the past, often knowing no higher law than that of chance, planting, rearing and gathering his crops under the leadership of luck, ignorant of much that he could have for the asking, and, in his ignorance, committing the fatal mistake of entailing ignorance upon his children. But, in the clearer light, even this man is becoming broader in his cultivation, while the advanced farmer, keen to take advantage of the signs of the times, quick to adapt his wares to the market and becoming 



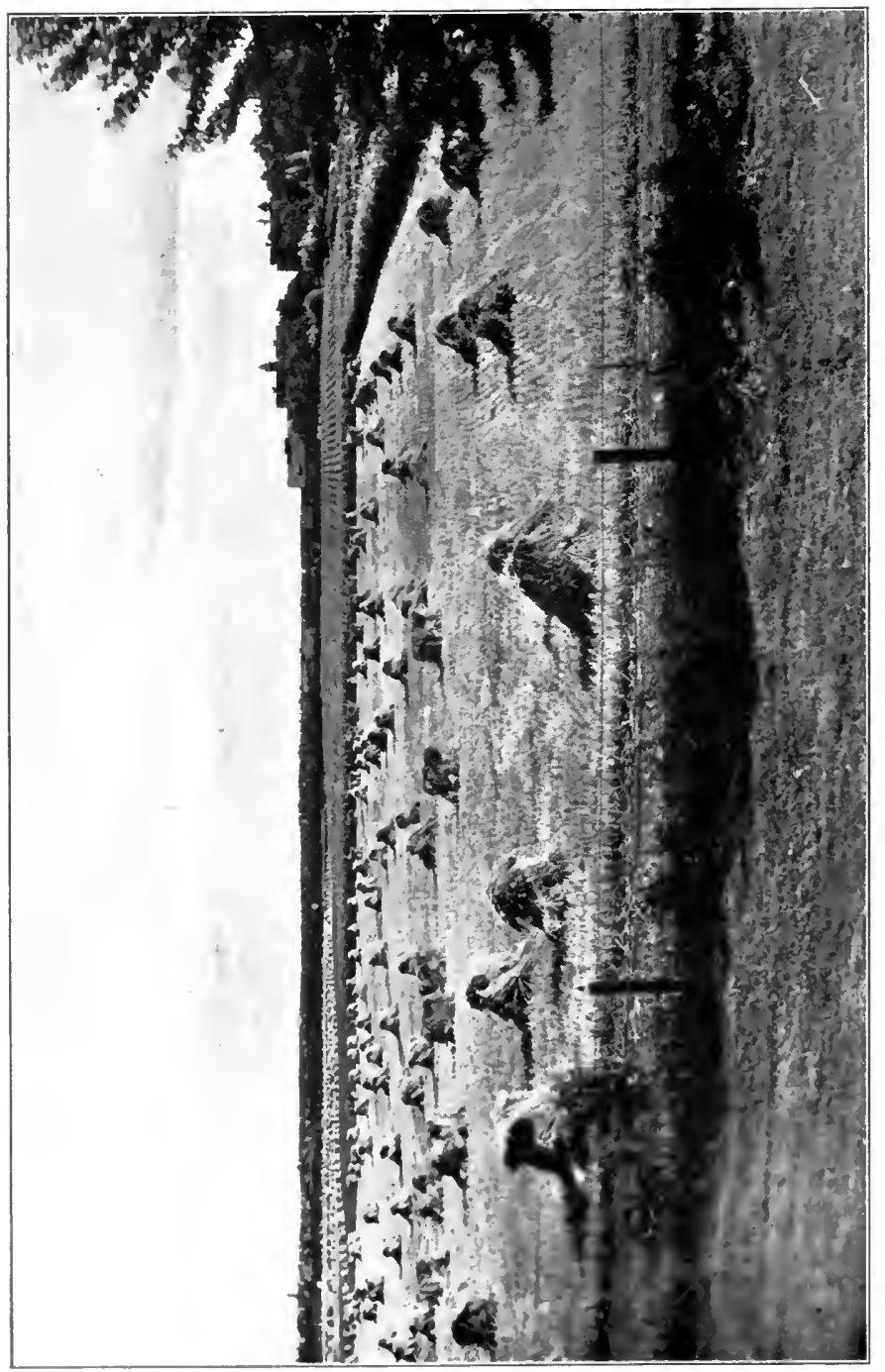

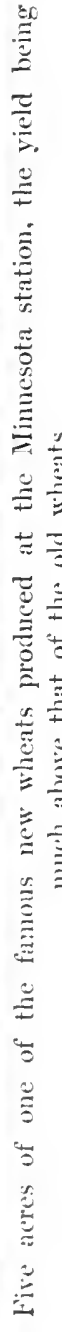


more strenuous in his efforts to protect that market, is coming clearly into his own. He is heartily interested in the work of his sons and daughters, as they come back to the farm from the agricultural colleges, brimful of the things he is anxious to know more about and of which in his day of meager schooling even his teachers were unaware. He is alert, up to date, a commanding figure in his community.

A generation ago many a young man went into farming because his father was a farmer before him, or because it was the one occupation among men which did not need any preliminary training. He reaped what he sowed. Each succeeding year saw the granary heaped fuller of disappointments. Each year opened with an intenser dread of the future. Each year closed with his, wife, his children, saddest of all, with the man himself, more completely given over to an intense, abiding hatred of the farm.

But today the advanced tiller of the soil must come up to his calling as fully equipped for service as the lawyer, the editor, the doctor, the captain of industry; for the curious fact has developed that the calling in which the un- 


\section{THE NEW EARTH}

lettered and untrained man was once supposed to have as good a chance as the educated one, is now the calling in which wide and varied knowledge is as imperative as in almost any other known among men.

It will be seen, as we go onward, that many a strange and curious event has lately come to pass in the realm of the New Earth. The period of the New Earth is more than a renaissance, a revival; - it is an era of creation, the most remarkable in history. 


\section{CHAPTER II}

\section{THE BRAIN OF THE EARTH}

W HEN the grass is wet with dew and the sun is coming up over the wide reaches of prairie and hill, and there is a song in the throat of every bird, the farmer of the Old Earth gives scant thought to the soil beneath his feet, the most wonderful factor in the production and sustaining of the life of the world. Its strange functions, the activities of the teeming life shut up in its dark chambers, the life history of the myriads of workmen in its silent factories preparing food for his wheat or his barley or his corn,--all this is to him a sealed volume. To him it is merely the soil his forebears plowed, the same soil the moccasined feet of the Indians softly pressed not many years gone by,-a little more shopworn, so to speak, than when he took it from his father, but the same prosaic, uninteresting earth which he has disliked from boyhood, from which he wrests sometimes a generous but more often a scant 
living, to which he is bound by the chains of debt.

If he would only look a little deeper, if he could only realize that it is no longer the old world of his forebears but a new, vital, marvelously interesting earth, how easily might all be changed, how might his interest be heightened, and, in the newer light, how easily may he break his chains and set himself up a free man. Instead of the ancient earth, timeworn and rapidly growing infertile, it is now a rich, productive earth, adaptable to all needs; not merely a thing to dig and plow and curse, but a noble field, throbbing with life and fraught with vast possibilities.

But we need not too sharply lament the ignorance of the farmer of the Old Earth, for it is only within a generation or two that even those who have studied it most closely have begun to realize,- and even now but dimly,its character and its possibilities; while to many of the millions bred to the ways of the town it is, in truth, far more deeply a terra incognita than to the farmer of the ancient days. The great German chemist Liebig in the century just closed, recognizing from his vantage 
ground somewhat of the possibilities of an occupation then in its infancy so far as knowledge went, set forth this principle: "Perfect agriculture is the true foundation of trade and industry; it is the foundation of the riches of states."

In a still more definite and practical way this is appreciated today by those who are giving their lives to the service of the New Earth. Most important of all this service is the study of the soil, the fundamental factor in all the varied lines of life that branch out from the main trunk of agriculture. How to conserve this soil, how to feed it, how to restore it to life when dead, what it is composed of, how it is formed, how to interpret it, so to speak, so that any man may understand it,- - these have been, and still are, among the problems presented.

And so arose the study of soils, enlisting the closest attention of the chemist. the bacteriologist, the geologist, the agronomist, all that relatively small but powerful coterie of men who are the investigators and interpreters of modern agriculture.

Such a man as one of these meets the farmer 
of the Old Earth a-field in the soft spring sunshine, and from different parts of his field takes up samples of the soil he is plowing, mixes them well together, and finally takes out of the mixture a tiny amount, not more than would fill a child's small thimble. He does not need to look for this or that ancient and superstitious sign of the soil. He does not need to ask what were the implements used to cultivate the crops of former years. He needs only to take this tiny composite sample and put it through the processes of physical and chemical analysis: - when he has finished he can tell the farmer whether or not he is planting what he ought to plant in order to bring the best results. He can tell him what to do, or what not to do,if he is planting unwisely,-in order to bring his broad acres up to their highest productivity. Oftentimes his soil is unbalanced in its makeup. It may contain too much, or too little alkaline matter instead of valuable humus.

Is he a truck-farmer, planting for the early and profitable city market? 'Then the soil for his lettuce and peas and beans and onions and radishes must be of a certain, well-defined structure,-it must have at least one billion, 
nine hundred and fifty millions of particles in a cylinder one-fourth of an inch in diameter and half an inch long,-the little child's thimble, the approximate measure of a gram. Is he going in for ordinary summer and autumn vegetables,-corn and cabbage and potatoes and squash and eggplant and the delicious small fruits that may fill in many a spare spot and line many a vacant compartment in his pocketbook? 'Then there must be at least two billion additional particles in each gram of his soil, or good results will fail to come. If he is a wheat planter, he may be sure the crop will be lean and weak if there are not at least ten billion, two hundred millions of particles; while, for wheat and grass lands combined, full fourteen billion, seven hundred millions of separate particles must be found in the little thimble.

If the farmer has but just settled upon his new land, ignorant of its measure of productivity, he may as well move onward to some other region if the soil beneath his feet does not have at least one billion, seven hundred million of particles per single gram. 'These minute particles must also contain all of the elements of fertility in a well-balanced form. 


\section{THE NEW EARTH}

The particles in a single cubic foot of average farm soil for general use, usually roundish in shape, expose to the roots of plants an area of surface three acres in extent. To show how very small these particles are, it should be noted that fully one-half of the cubic foot of soil is air-space, so that if it were not for the air it would contain twice as many particles. If sixty thousand particles of a coarse clay soil were placed side by side in a line, it would be but twelve inches long, while the line itself would be only the two ten-thousandths of an inch in width.

It is in the searching study of the soils of the earth that such facts as these are developed, interesting in a sense because of their novelty, but immensely more interesting because of their practical value. In some of the western agricultural states, for example, hundreds of farmers send samples of their soils to the chemists of the agricultural colleges of the states in order that they may test the soils and find out whether or not the farmers are using them to the best advantage. In some instances the soils are unproductive because of excess of strong alkaline matter; or, again, the 


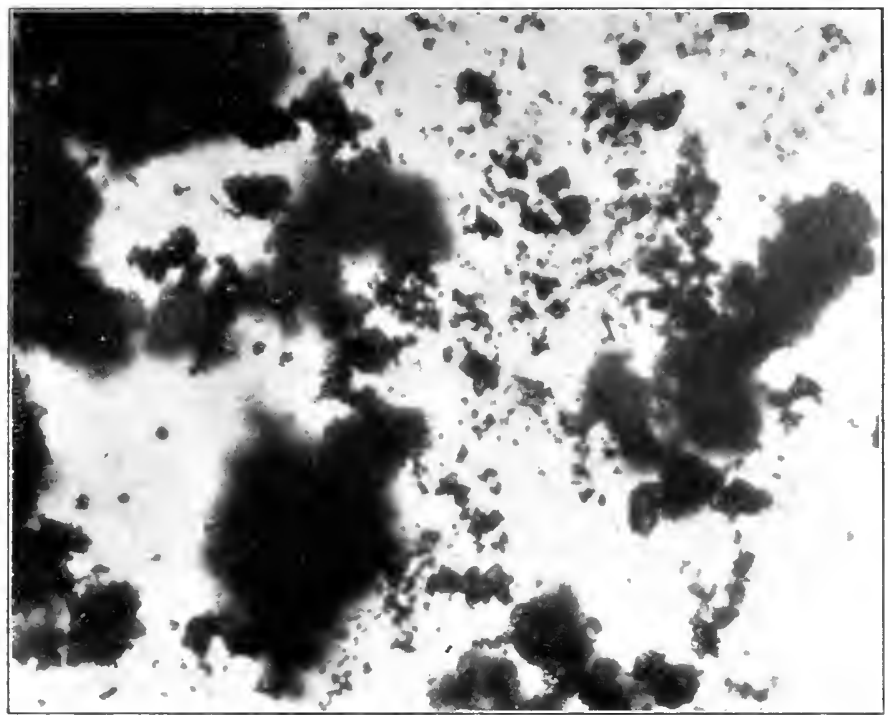

Microscopic photograph of soil ot ereat fertility

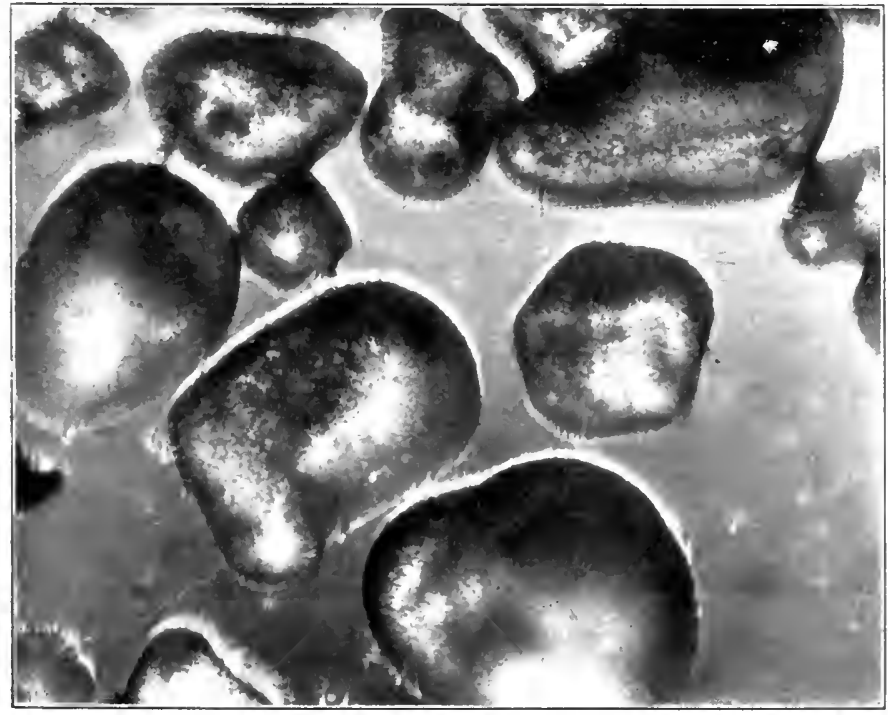

Microscopic photograph of a soil having no fertility. absolutely sterike 

soils may contain an excess of injurious acid material. In each case the soil requires a different treatment. The chemists and soil experts, in turn, tell the farmer what changes are advisable, or, in case the soil has never been cultivated, indicate to the prospective settler just what crop the soil is best suited for.

'The difference between soils and the importance of understanding this difference was brought closely to the writer's attention in preparing a series of microscopic photographs to illustrate rich and lean soils.

'Taking a pinch of earth from one of the richest wheat lands on the globe, it was placed on a slide under the microscope. A knock from the finger and the thickest portion was removed, leaving only a faint dust upon the slide. But, faint as this dust was, it was yet too dense for photography, so it was necessary to blow hard upon the glass in order to remove every loose particle and leave only an almost imperceptible film. And yet, so marvelously rich was this soil in vegetable-mold, so near together the billions of particles in a gram, it was only by the utmost care that a photograph could even then be made. 
Sifting down upon another slide some particles from a sterile soil, in which there was no trace of fertility save in those infinitesimal spaces between the particles in which might still be found some vagrant phantoms of humus and mineral salts, and blowing likewise upon the glass, a thin coating remained from which another photograph was made. Looking through the microscope as the light came up from the reflector below, the particles of the sterile soil, unlike those of the richer soil, were far separated from each other, standing out like huge boulders of quartz or granite, their many facets sparkling like brilliants.

In the one case, the particles, standing inconceivably close to one another, formed the rich soil, the billionaire soil one might call it, fertile, enduring, abounding in wealth for the individual and the nation; in the other case, the particles were of poor quality and far separated, the soil was practically worthless, needing constant supplies of artificial fertilizing material in order to make it even fairly productive. In one case, the enormous number of particles, held close together, were enabled to hold moisture an indefinite period, like the surface of a 
close-meshed silken cloth; while, in the other case, the moisture would run down between the particles like a stream of water pumped through a coarse sieve, leaving nothing behind it. The rich soil would conserve the moisture, the poor soil would waste it.

The water of the most refreshing rain will rapidly disappear in a coarse, loose soil like the one photographed. And, even where the soil has considerable food supplies, the water would be of little value, swiftly disappearing and leaving nothing stored up for a day of drought. Putting it somewhat contradictorily, the coarse soil puts by nothing for a rainy day.

And water is all-essential for these soils. Investigation has shown that, to produce an average acre of clover or potatoes, at least four hundred tons of water are needed for the season; for an acre of peas, wheat or oats, three hundred and seventy-five tons; for an acre of corn, three hundred tons, while, to bring an acre of sunflowers to maturity, at least six thousand tons of water are needed, twelve millions of pounds of moisture.

One English investigator holds that at least six hundred and fifteen tons of water is taken 


\section{THE NEW EARTH}

up in producing two and one-half tons of grain. Ordinary field crops transpire about three hundred pounds of water for each pound of dry matter produced.

This transpiration is a curious act. While much of the water that comes to the fields is lost in the soil through passing down between the loose particles and considerable is dissipated by evaporation, a vast amount is transpired by the plant. That is to say, the plant pumps it up from the earth through its roots and stem, uses what it needs, and sends the rest off into the air through its leaves-transpires it. Hot dry winds may cause crops to wilt merely because the water suddenly lost by transpiration is more than the pumping capacity of the plant.

Just as the wheat and the corn, the rye and the oats of the farmer are of little food value until they have been crushed and ground and made fine and powdery, so the soil of the earth was valueless until the all-wise Ruler put his great ice-mills to grinding, throwing into the mighty hopper boulders and hills of stone, and here and there the huge slice of a hoary mountain. When the mills had finished the grinding 
and had discharged their product over the earth, there appeared the beginnings of the soil of today. Other agents were at work besides the ice-mills before the soil was brought into proper condition for the production of vegetation for the enrichment or the adornment of the earth. Some geologists, who have studied the great frame of the earth, have maintained that its surface was once a massive, unyielding shell of rock, barren, without sign of life, fit haunt for Death. Out of this rock came our soils, rich or lean, ground by the great glaciers, the ice-mills of God; broken up by the alternate swellings and shrinkings of heat and cold; dissolved by the restless waters through the eons of pre-historic times, the water wearing off particles and transporting them in solution to be deposited on level plains or along lake and waterways; disintegrated by certain early, low forms of vegetable life, which left deposits of decayed matter in among the grindings of the great ice-mills,-a mighty, age-long process, resulting at last in the soil of the earth of today, fully furnished and prepared for the use of man.

Here and there, owing to an uneven dis- 
tribution of the bran of the ice-mills-the coarser refuse of the great grindings of the glacial days - appear the unfruitful soils, those which contain less than their allotted one billion, seven hundred million particles to the gram,--soils that today are worthless as they stand, but which the scientific agriculturists of the future may yet bring under the plow, as thousands of acres of barren soil, fertile by nature but unproductive because of the lack of moisture, are being reclaimed in the arid regions of the $W$ est.

But there is still another important avenue from which to approach the soil of the New Earth,- that which leads through the mysteries of agricultural chemistry. The physical character of the soil, its material form and composition, is of great importance, and the immense labor already performed is probably little more than a promise of what shall be accomplished. It is the part of the agricultural chemist of today to determine not only how many and what kinds of particles are in a given soil, but what the soil is composed of, whether it is, or is not, by nature fitted for a certain crop; what crop the farmer should substitute 
if he is on the wrong track in his farming; what element in the soil is lacking if the soil is not up to average productiveness; how this missing element may be supplied to the farmer at a maximum of service and a minimum of cost. It is estimated that the farmers of the United States in recent years have paid out at least seventy millions of dollars annually for commercial fertilizers. In a generation, at this rate, the tillers of the soil in this country arc expending over one billion, five hundred millions of dollars for fertilizers. 'The greater portion of this vast sum will be saved to the farmers, amateur and professional, as they come to a closer study of their soils and as they learn how to restore when depleted, how to avoid such depletion in the future.

While the soil, as physically composed, has but comparatively few substances in its makeup, being formed of ground-up rock and decayed vegetable and animal matter, as chemically constituted it has many substances, nearly serenty elements being found in the earth's crust. Only twelve of these, however, are pronounced essential to agriculture, while only four of the twelve-nitrogen, phosphorus, 


\section{THE NEW EARTH}

potassium and calcium - are liable to be lacking in any given soil. When any one of these four is wanting, however, dire results follow. 'They are the fundamental quartette without which there is no harmony in agriculture.

It is a part of the work of the agricultural chemist in these days to make analyses of the soils sent him, in order to determine not only their structure but whether or not any of the chief parts in the general harmony are below pitch or are lacking altogether; or whether the soil contains any injurious materials, as acid or strong alkaline substance. There are scales for the weighing out of small portions of soil, so delicately balanced that they will weigh a pencil-mark upon a slip of tissue paper. Small portions of the soil are thus weighed out and then treated with chemicals, washed, dried, burned, put to every sort of test.

Working in a chemist's laboratory one day, I took a pinch of the rich wheat-land soil of the famous Red River Valley of the North, and placed it on a thin platinum scoop about as large as a silver dollar, holding the scoop over an intense heat, fully $1,000^{\circ}$ Fahrenheit. Swiftly the blue-green flame of the gas turned 



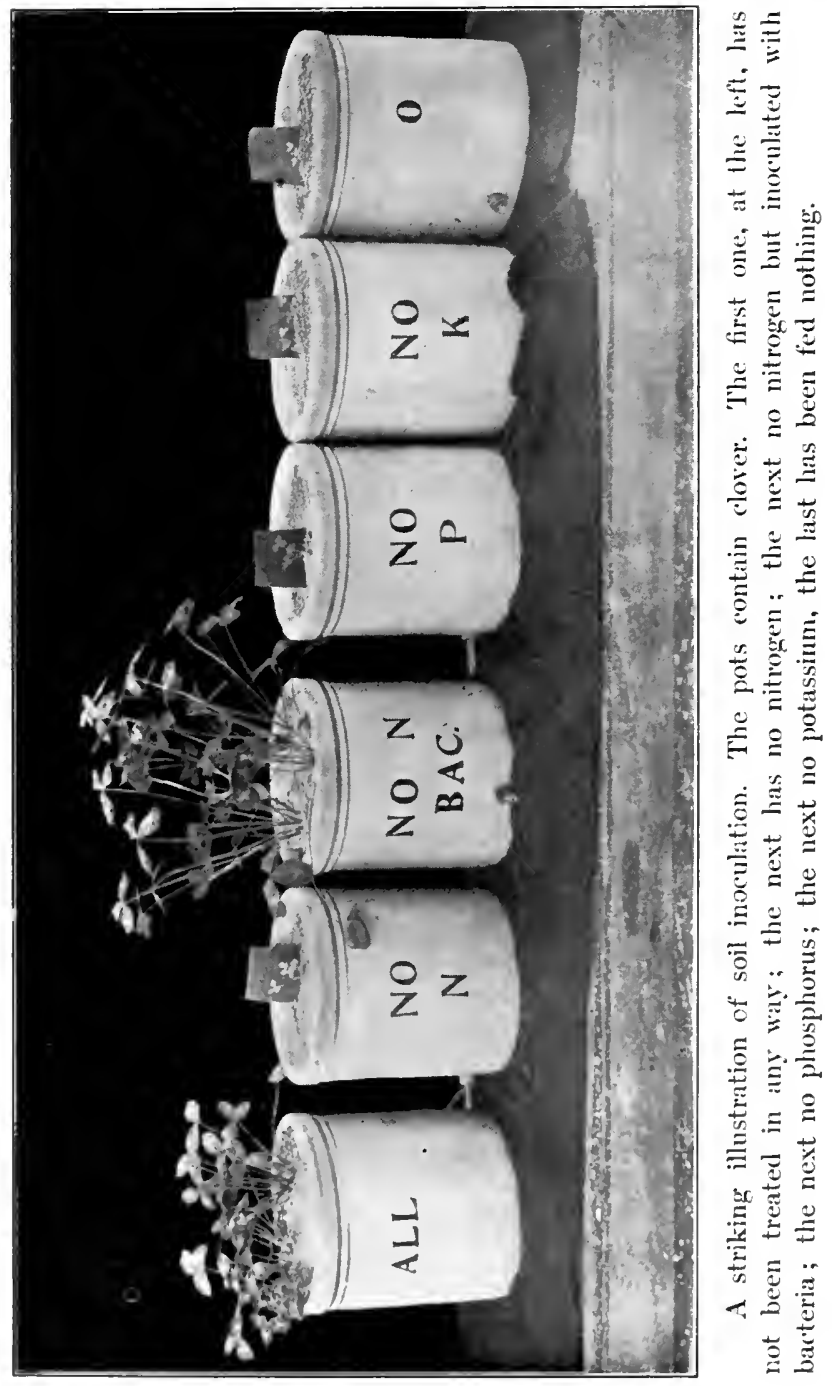


the dense black soil to an ashen gray, then from gray to salmon, and finally to a dull red. Every particle of the life-supporting nitrogenous substances of the soil had been burned to death; there remained on the scoop only a fine red dust. When it was photographed it had only a vague resemblance to the rich black particles which had held in their grasp the marvelous secret of plant life.

The dark vegetable or organic substance in the rich wheat soil which, before burning, was so hard to photograph-the humus as it is called - is one of the main sources of nitrogenous food for the wheat plant, keeping it in health from day to day and furnishing it with strength against a day of disease. There are a dozen main items on the plant's bill of fare, but humus, to supply nitrogen, it must have, whatever else it rejects, and it rapidly loses strength when the nitrogen is low in the larder.

One agricultural chemist, in demonstrating the importance of varying or rotating the crops on a prairie farm, found out that a piece of wheat land under continuous wheat culture lost one hundred and seventy-one pounds of 
one of the elements of fertility, nitrogen, per acre in a period of five years, while, under a system of rotation, each year planting a different crop, the fertility of the soil not only maintained itself but actually increased by sixty-one pounds per acre. When the wheat is grown continuously, as in certain of the western states, notably the state of Iowa a few years since, the humus, which is the binding material of the soil holding the partioles together, rapidly decays and the liberated nitrogen is taken up by the wheat plants, ever hungry for food; the water filters down between the loosened particles; the soil becomes lean; the crop fails. 'Tens of thousands of acres of land in Iowa, and other central-western states, once yielding remarkable wheat crops suddenly began to deterioriate, then failed utterly,- the soil had entered its unanswerable protest. From a single farm of one hundred and sixty acres where exclusive wheat farming is followed, there is an annual waste of fertility equivalent to twenty-eight thousand five hundred pounds of nitrogen, five thousand pounds of potash, three thousand pounds of phosphoric acid. 


\section{THE BRAIN OF THE EARTH}

Not only must the soil be studied and tested as to its chemical and physical properties, but there must be artificial growing of plants in the soils under artificial conditions. After repeated washings, a soil is prepared from which has been taken every particle of nutriment for plant-food. 'To make sterility absolute, the soil is digested in a powerful acid and then the acid is removed. 'The grain to be tested has been sprouted either in water or warm sand, and is then planted in the barren soil.

Naturally it would be but a matter of a few hours before the plant would droop and die under these conditions, but the chemist is ready with supplies of the four primary foods with which to feed the plant in the sterile soil,- now one food, now another, now two in combination, now three; now ceasing from all food, and then, when the plant is at the point of death, restoring it as if by a miracle by a single meal, seized upon by the plant with all the eagerness of one in the last days of starvation. The plant is nourished, over-fed, underfed, or starved at will. There is a strange fascination in these acts of the chemist, as when, for example, he allows a plant to go on for 
four or five days without any lime in its food. Hour by hour the plant, in its blind, insensate, ever-persistent way, searches for the missing food, and hour by hour, baffled in its search, it steadily fails. At last, when five days have passed, a meal of the long-needed lime is served, and, in less than five hours' time, the dying plant is restored to life and soon to normal health.

The soil has been divided into various arbitrary classes according to the size of the particles, among these divisions being medium sand, fine sand, very fine sand, silt, fine silt and clay. Prof. Harry Snyder, in his book on "Soils and Fertilizers," distributes the soil particles for various crops as follows:

"Potato and early garden truck, sixty per cent medium sand, twenty to twenty-five per cent silt, five per cent clay.

"General truck and fruit soils, not more than forty per cent sand, ten to fifteen per cent clay, forty to forty-five per cent silt.

"Corn soils, forty" to forty-five per cent medium and fine sand, fifteen per cent clay, forty per cent silt; the strongest type of corn soils having the proper mechanical composition 
for the production of crops of sorghum, cotton, flax and sugar-beets.

"Medium grass and grain soils, thirty per cent each, fine sand, silt and clay.

"Wheat soils, varying from twenty to thirty per cent of sand, twenty to thirty per cent of clay, fifty to seventy-five per cent of silt."

But the soil is something more than mere earth. It is the home of unthinkable myriads of living beings, vast, uncountable colonies of life. It is low life in its order, to be sure, but it is as truly life as the life of the most highly organized scientist who works amidst its mysteries.

In the burning of the pinch of rich soil upon the platinum scoop I did more than merely to destroy the dark humus, for in a moment's time I put to death more living things than there are human beings upon the globe. In a normal soil, not so rich or full of life as this, more than one billion, six hundred million bacteria have been found in a single gram. They were infinitely minute, but they were throbbing and pulsing with life when they met death in the flames.

These marvelous forms of life at work un- 


\section{THE NEW EARTH}

ceasingly in the soil, the great brain of the world, are in some ways the least understood of all the forces of the earth. 'They must be considered further in dealing with soil inoculation, the restoration of worn-out soils by means of bacteria brought from other soils, one of the most curious developments in the many-sided life of the New Earth. 


\section{CHAP'TER III}

SOIL INOCULATION

THE word bacteria has come to have

a most suspicious appearance. Bacteria have so long been identified with disease and death that it seems difficult to look upon them as of help to the race. And yet they are of enormous importance to every man who raises a flower or a grain of wheat or a tree of rich fruit.

While it has been known for at least two centuries that these bacteria exist, it has only been since the opening of the era of the New Earth that they have been studied with any degree of satisfaction. They exist everywhere, in earth and air and sea. They were believed at one time to have animal life, but they are now almost universally accepted as low forms of vegetable life. Over a thousand different kinds are now known, and the list is being steadily added to as knowledge of them increases.

Some have the singular power of cutting 


\section{THE NEW EARTH}

themselves in two, each divided half in turn subdividing itself; and so they go on and on increasing at a marvelous progression. They are so infinitely small that it is impossible to conceive the rapidity of their increase when they are in the act of multiplying themselves. One of them, according to a bacteriologist who had studied it closely, would, if left to itself, produce seventeen million descendants in twenty-four hours. Another scientist calculates that another particularly rapid multiplier could produce, if it had plenty of food to eat in the meantime, four thousand, seven hundred and seventy-two billion progeny in a single day. In three days' time the reproduction, if unobstructed, would be so great that the mass would weigh seven thousand, five hundred tons.

Some of the bacteria are round, sorne elliptical, some thread-like or spiral, some branching, some rod-like. Each one has a central life point, which the word cell describes as well as any other. When they divide themselves, each half is given a complete life of its own with all the powers and functions of the old. 'They differ from the plants which we see growing 


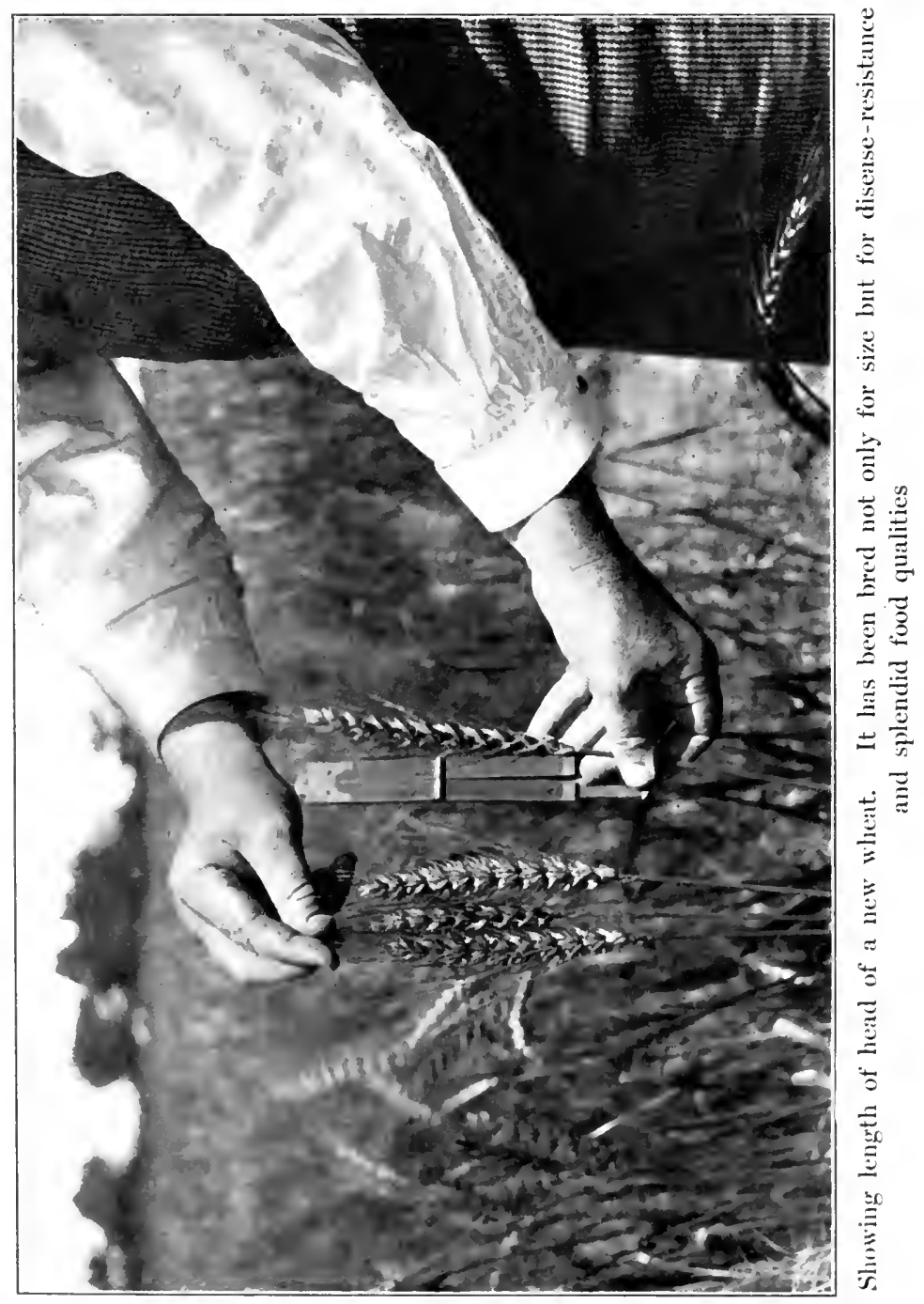



about us in that they have no chlorophylthe green material which gives color to the plants.

At the Kansas Experiment Station, in connection with the State Agricultural College, it was found that there were as many as one billion, six hundred and eighteen million, six hundred and eighty-one thousand, eight hundred and ten bacteria in a gram of soil from a field under examination, while another field had only a few over a million. They rapidly decline in numbers as you go down in the soil, to a point where none is ever found. In a single gram in one soil six hundred and fifty thousand were found at eight inches, five hundred thousand at nineteen inches, five thousand, six hundred at fifty-five inches and none at sixty-five inches. Another test made in Europe showed one million, six hundred and eighty thousand at the surface and four hundred and ten at a distance of six feet below the surface.

Many different families of these bacteria live in the earth, making their homes in the soil. They help to decompose it, thus transforming it into food. They draw vast stores of food 


\section{THE NEW EAR'TH}

supplies from the air. At every point they act as agents in advancing the interests of man.

Four-fifths of the air we breathe is plantfood, nitrogen, one of the most valuable items in the larder of the crops. Some of this nitrogen is available in one form, some in another, but it must all be put into such form that it may pass into the system of the plant and be utilized in the building up of stalk and leaf and ripened seed. Upon every acre of ground there are resting about seventy-five millions of pounds of atmospheric nitrogen, which gives some idea of the vast store of food provided free of all cost.

Now, it is not at all unlikely that the farmer of the Old Earth looks with distrust upon such a thing as the inoculation of the soil, quite as he has looked upon many other new things which, to him, were but theoretical fads, of no practical value. 'To spend the money of the state in bringing native bacteria from the soil of one commonwealth to be put in the depleted soil of another, in order to restore the exhausted soil,-it would be to him as great a waste of money as that spent on the education of farmers' sons and daughters. 
But the newer farmer and gardener and the man of moderate means, who dearly loves to have his garden or a bit of wild land somewhere which he can subdue and bring under cultivation, together with that constantly increasing number of city folk who have abundance of means and who are ennobling America by their splendidly managed estates, - these are dwellers upon the New Earth; to them such a discovery as that of the inoculation of soils must come with a wider sweep of interest than the finding of a star.

I saw in a chemist's laboratory one day a series of pots containing growing plants. 'There was a section of the state in which the land was worn out by injudicious cropping. In one of the pots was some of the depleted soil from this region, in which a few spears of clover were pitifully struggling to grow into what would be, at best, but a lean and starved maturity. The plant was stunted, yellow, thriftless, type of the plants which you may see in any soil which has been cropped until worn out, until it has, in large measure, lost its reproductive powers. The plant was creeping slowly along toward a seedless cnd. 


\section{THE NEW EARTH}

Alongside the same plant was a pot filled with soil of precisely the same character as that used in the first pot, taken from the wornout land. It had not been cunningly fed by the chemist in order to coax it up to thrift. It had been given no advantage, either, in point of moisture, heat or sunshine. Precisely the same kind of seed had been planted in each case. But the plant in the second pot was beautifully green, where the other was a sickly yellow; it was tall and strong, where the other was stunted and weak; it was thrifty and respectable, while the other was lean and shiftless, a very beggar among plants; it was hastening on to a fine harvest, while the other was lagging behind on its way to a withered immaturity.

The only difference between the two was that around the seeds of the one plant, when it was placed in the pot, was sprinkled some earth, plain, simple dirt, brought from another state, slightly different perhaps, in physical characteristics, possibly ground a bit coarser in the ice-mills of the past eons, possibly a trifle darker in hue; but, to all intents and purposes, a bit of similar dirt. 
That which wrought the wonderful change was a colony of bacteria, low in the scale of life, undistinguishable save by a powerful microscope, but living, moving things, as truly alive as the waving trees or the green meadows, or, in a deep and solemn sense, as man himself.

On a much larger scale than was possible in the chemist's laboratory, similar tests have been made at the Kansas Agricultural College referred to. Here soil from another state has been used to inoculate the Kansas soil in field tests. As in the case of the chemist's pots of grain, the only thing done out of the ordinary was to place the soil known to contain the bacteria around the seeds at planting. 'The results on the larger scale were even more wonderful.

The Kansas investigators were working with the soy bean, which is a fine feeding crop. Long ago it was discovered that certain plants, as the beans, clovers, peas, vetch, alfalfa and the like, form upon their roots little bunches, or tubercles, as they are called. Nobody knew what these bunches were good for, and a good many thought they were harmful excrescences which should be cut away. 


\section{THE NEW EARTH}

Science sought out the meaning of these tubercles,-why were they formed on these particular plants, what purpose did they serve, were they essential, or inimical, to the plants? Investigations showed that the growths were not abnormal but were necessary, and that the plants which did not have them were less thrifty than those which did. More than this, it was found that the growths were the home of a tiny organism, a beneficent bacterium which, working in some way, yet shrouded in mystery, induced this enlargement upon the plant roots and made the bunch its home. Still further investigation showed that the billions upon billions of bacteria who dwelt in this little round home on the root of the plant, were actively at work for man. They performed their work, it was found, with the utmost skill and accuracy, leaving nothing to chance or luck, but doing all under a systematic, judicious law.

The task of these bacteria is to take the nitrogen from the mighty reservoir of the air, this four-fifths portion of the entire atmosphere, and, down in their tiny laboratories in their homes beneath the surface of the dark 
earth, transform it or adapt it, or whatever may be the process, no one knows what the precise act is,- to change it from the nitrogen of the air into the nitrogen suitable to be taken up by the plant.

The bacteria do not do this work merely to store up supplies of nitrogen for their own uses, as the chattering squirrel lays by his store of nuts for the winter's fare. 'The bacteria take the nitrogen, transform it, and send it through the membranes of the plant into the very life tissue, the nitrogen enriching the plant, and, at the same time, enabling it, through its many tubercles, to become a storehouse of nitrogen as well. Down in the darkness by night and by day, all through the life of the plant from sprouting to harvesting, the tiny bacteria are at work, needing no light and no air from above; for, so great are the atmospheric spaces between the billions of particles of the soil that there is a never-failing source of supply always at hand.

Many details of the life of the bacteria yet remain to be determined, many of the details in this marvelous act of nitrogen conversion, one of the strangest and one of the most mys- 


\section{THE NEW EARTH}

terious in all the strange functions of the earth. But the chief fact of importance in present consideration is that the once-dreaded tubercles are storehouses of food for future plant uses.

It so happens that in certain soils none of these particular bacteria is found. It was so in the case of the Kansas soil. So the attempt was made to take them from the soil where they were, so to speak, native, and transport them.

In this instance the soil transported was from the state of Massachusetts. It was dry, uninteresting dirt, not unlike dust in appearance. For several years soy beans had been planted on the farm at the Kansas College, but no nodules, or tubercles, were found upon the roots, no tiny storehouses of the precious nitrogen. 'This was considered ample proof that no bacteria of this kind were to be found in the soil. When it came time to plant, some of the soil from the eastern state, a twentieth of a pint to a hill, was put around the seeds. Alongside of these beans, but sufficiently apart to insure individuality of action, other beans were planted in the normal soil without the 
1 


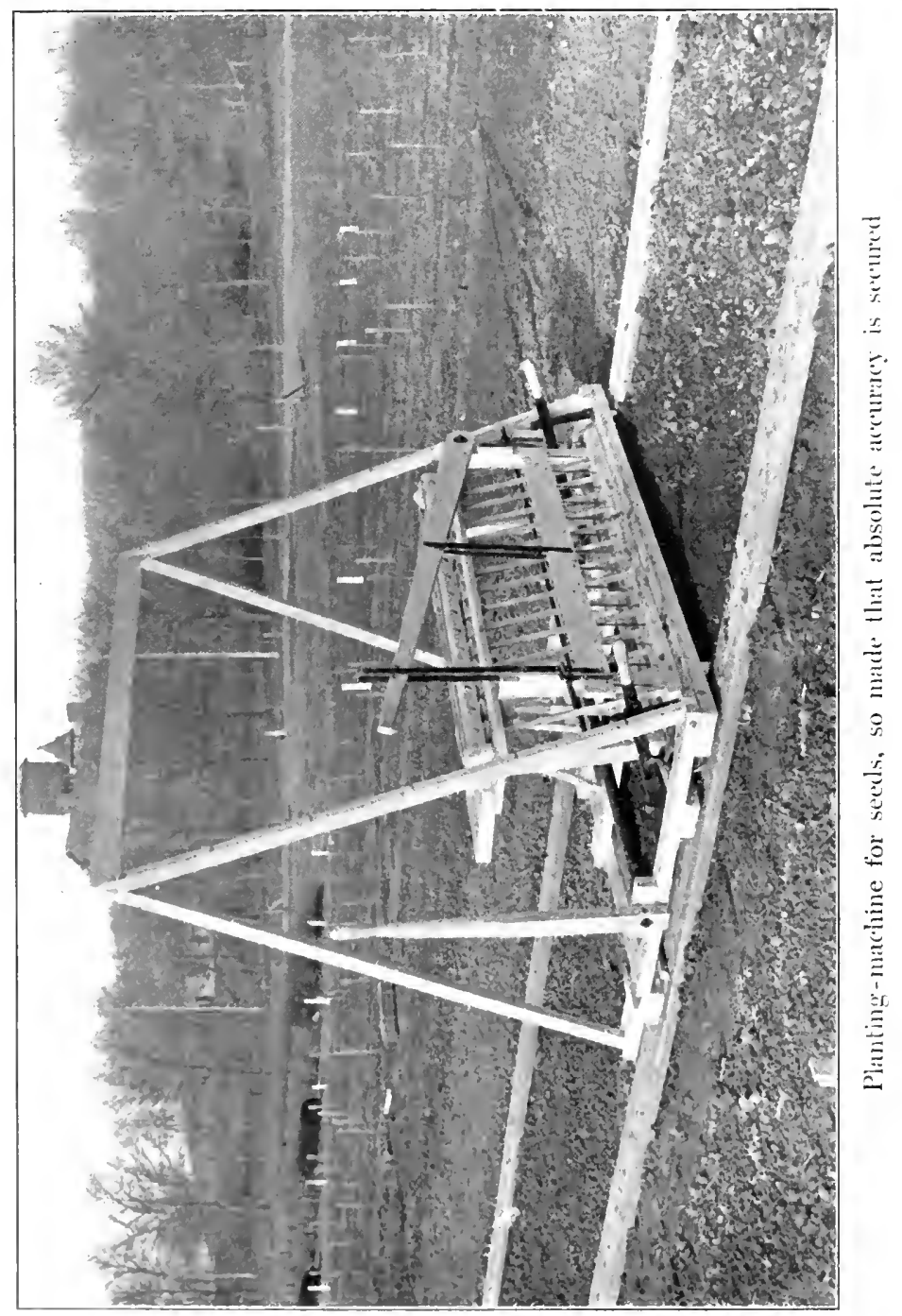


addition of the foreign soil. 'The experiments were carried on in small plots and in larger farm areas as well.

In all cases the results were the same; the beans which were planted in the pinch of Massachusetts soil produced roots abounding in tubercles, while those planted under precisely similar conditions, but without the eastern soil, produced no tubercles. It was found in greenhouse tests that the bacteria began their work of storing up nitrogen very soon after the sprouting of the seed, increasing their activity as the roots began to develop. When the beans were fairly well advanced, some of the hills were dug up, about two cubic feet of soil being taken up with each hill. After a thorough washing, tubercles were found in large numbers upon the plants which had been inoculated, but not one upon the plants which had not been inoculated.

In order to find out whether or not the soil once inoculated would become of itself a medium for further inoculation, experiments were undertaken with the Kansas soil in which the beans had been grown, and proof was soon at hand that the home soil, once inoculated, 
was just as effective as the imported soil. It is probable, also, that the soil once inoculated always remains so.

While the difference in the yield at first was not large, the plants bearing tubercles were superior to those not having them, both in seed and fodder. The plan of scattering the inoculated soil upon the surface of the ground proved an utter failure. The soil containing the bacteria must come in contact with the seeds. Beans planted with one thousand pounds of Massachusetts soil scattered broadcast showed an average of only seven tubercles per twenty plants, while, when the beans were put in with drills, with only three hundred and seventy-five pounds of the infected soil per acre,-the infected soil coming into contact with the seeds, - the tubercles averaged thirtyfive per twenty plants. Where the Massachusetts soil was spread more thickly in the bottom of the drill furrow and the seed dropped upon it, twenty average plants grew five hundred and nine tubercles, a single plant bearing seventy-one and another sixty-nine.

But still more important than all this is the fact that the tubercles upon the roots of the 
plants are soil-restoratives. 'They are fertilizers of the most approved type. They bring nitrogen to the soil and they take no element of fertility from it. When a certain cereal has been planted for a series of years upon a given soil, as in the case of wheat, the nitrogen becomes exhausted because of the exacting demands of the wheat plant and the soil refuses longer to produce a crop; it is worn out. The land is abandoned for wheat culture-possibly it lies fallow for years. It is the part of the beneficent bacteria, abounding in the tubercles on the roots of the peas or beans or clovers, to supply the waste nitrogen to the soil, taking the free nitrogen of the vast reservoir of the air and converting it into the proper form for assimilation by the plant. In the case of the soy bean planting in Kansas, the beans, where there were no tubercles upon the roots, kept on exhausting the soil as any other crop would, but as soon as the bacteria were introduced, inducing the growth of the tubercles, the exhaustion of the soil was checked, the soil became enriched.

In the one case, the farmer of the Old Earth would keep on planting crop after crop, 


\section{THE NEW EARTH}

steadily reducing the yield until, at last, the soil was worn out and ruin stared him in the face. Now it appears feasible for him to restore his soil nitrogen simply by inoculation.

In this connection it is of interest to note that the Department of Agriculture in Washington has begun the work of sending out bacteria for inoculating the soil direct.

Certain plants bearing root-nodules, the leguminous plants, have long been used as green manure, the farmer plowing under the green plants in order that the soil might be enriched through the rich deposits of nitrogenous matter coming from the decaying roots, and stored up by the bacteria from the nitrogen of the atmosphere. But in case the plants have no nodules upon their roots, as in the case of the soy bean in Kansas before inoculation, such plants are of no more value for plowing under as a green manure than any other grain or grass. Curiously enough, it may be noted in passing, the bacteria of the different legumes, as peas and clovers, are different, the bacteria of one plant refusing to make its home upon the roots of another, and vice versa. 
In Alabama, one of the great cotton-producing states, the cow-pea, another legume, is in much favor as a green manure. The danger of soil exhaustion has long been imminent, indeed its disastrous results have been severely felt. At the experiment station, in connection with the state agricultural college, the subject of soil inoculation has been under consideration for several years. It was recognized that cow-peas have the power not granted to wheat, corn, oats and other cereals which must take their supplies from the earth through their roots. It was recognized, also, that, without the nodules upon the roots of the cow-peas they, like the other legumes bearing no tubercles, had no advantage over the near-by cotton, or the grasses or grains. The value of the cow-pea as a renovator of the soil was recognized, but a legume was needed which could be planted in the winter, which would not only add nitrogen to the soil when plowed under in the spring, but would prevent the winter rains of the South from washing the soil and leaching out nutriment.

Another of the legumes is called hairy vetch, a vine-like plant valuable for fodder, 
for hay and pasturage, and for plowing under for green manure to restore the soil. It was found that satisfactory results could not be obtained because of the absence from the soil of the bacteria which make their home upon the vetch. So, from a garden in which had once been grown the common vetch which had had the nodules upon its roots, a supply of earth was taken, mixed up with water and allowed to settle. Seed of the hairy vetch was then dipped in the water and planted.

The result of this liquid inoculation was remarkable. 'Two plots were planted, one with inoculated seed, one with uninoculated. In January the plants which had been treated were standing strong and thrifty, a rich green in color, while the plot not inoculated was sere and brown. The roots of the inoculated plants were well supplied with nodules, while the non-inoculated plants bore not a single tubercle. In the latter part of May, at harvest time, the inoculated plot was so heavy in its growth that it had to be cut with a scythe, while the other was so short that a sickle was used. On the plots inoculated with the bacteria from the garden soil, not only were 
there numerous nodules upon the roots, but the upper part of the plants above ground averaged about three feet in height; few branches of the non-inoculated plants were as long as eight inches. 'The two soils, aside from the inoculation, were treated in precisely the same way. In green forage, the inoculated plot yielded nine thousand, one hundred and thirtysix pounds per acre; the one not inoculated, nine hundred pounds. In cured hay, the inoculated yielded two thousand, five hundred and forty pounds; the other, two hundred and. thirty-two pounds. 'The increased yield of hay was nine hundred and ninety-five per cent, due to inoculation. Other tests, taking soils from different parts of the state and submitting them to laboratory growing, abundantly proved the wonderful advantage of inoculation. Pot experiments were carried on with crimson clover, also a plant which had largely failed in Alabama. On thirty farms the clover had been tried with unsatisfactory results, and, in the majority of cases, the roots examined showed a total absence of tubercles. A few specimens showed a very few quite small tubercles. The crimson clover on the farm of 
the agricultural college was a complete failure and no tubercles appeared upon the roots. The failure was pronounced a case of nitrogenhunger. Inoculation was then tried, and the results were wholly satisfactory. On soil from a cotton field which had been cleared twenty years the gain was seventy-one per cent; soil five years cleared, seventy-four per cent; woodland, three hundred and twenty-six per cent. The average of all the soils showed an increase due to inoculation of one hundred and fifty-eight per cent in tops and one hundred and twenty-eight per cent in roots.

Extensive tests have for several years been under way in Illinois at the state experiment station as to the importance of bacteria in producing the plant-food. Experiments were made with various legumes, among them cowpeas, soy beans, red clover, alfalfa and sweet clover. Emphasis was laid in these tests upon the fact that these plants, and others of their class which are known to restore fertility to soils, do not take their nitrogen from the air but are given it by the bacteria, which take it from the air and convert it into food for the plants. With the inexhaustible supply of ni- 


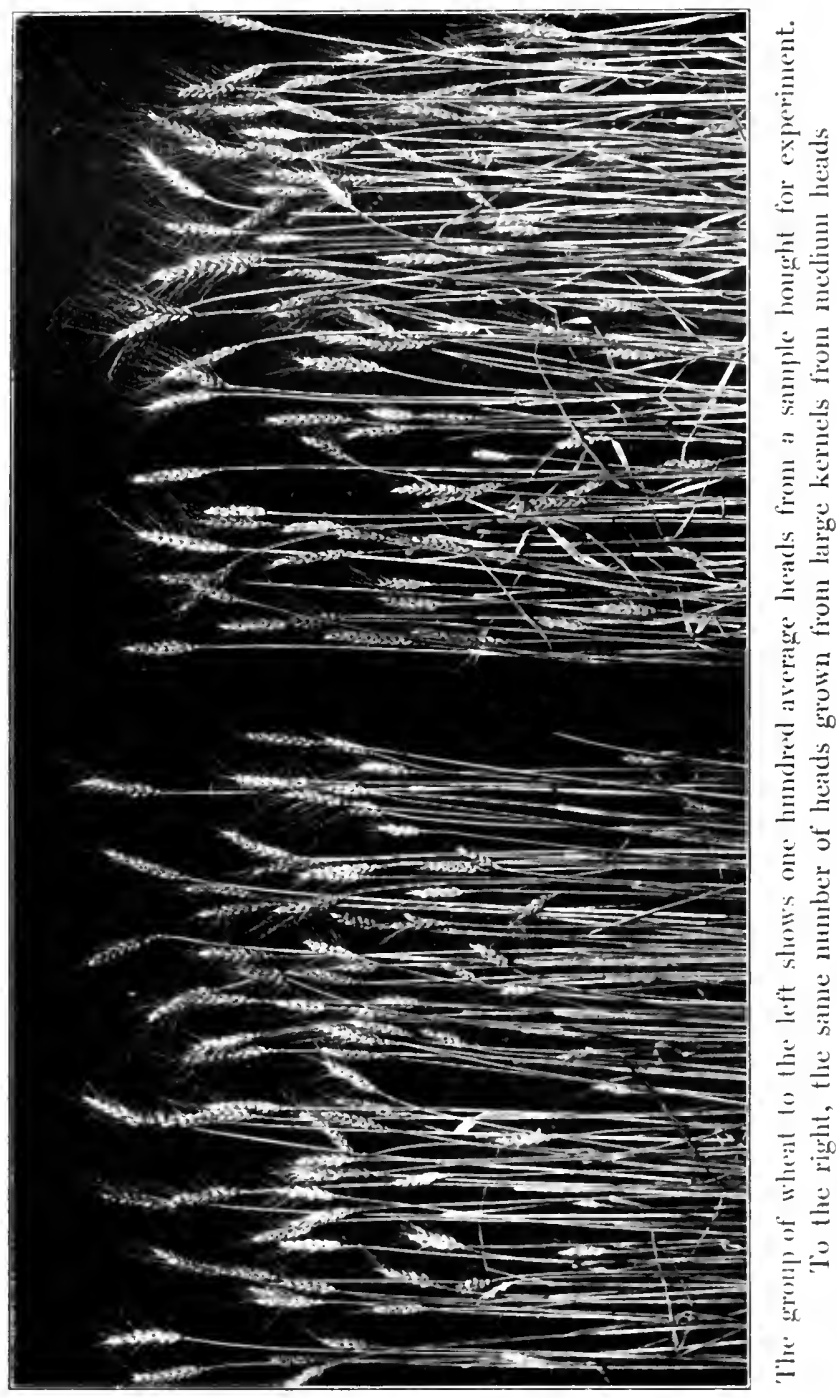



trogen in the air and with the bacteria ready at hand to take it up and feed it to the plants, man has a service without cost as significant in value as it is wonderful in character. 'The work done in Illinois has been remarkably successful. It has been a practical demonstration of the value of this new discovery in the realm of the New Earth. 'These conclusions, among many others, have been reached in Illinois; they illustrate the comprehensiveness of the work which is being carried on:

Soil nitrogen cannot be used by plants until it is changed to the form of nitrate nitrogen by the nitrifying bacteria.

Atmospheric nitrogen cannot be used by any agricultural plants, excepting legumes, and even leguminous plants have no power to obtain nitrogen from the air unless they are provided with the proper nitrogen-gathering bacteria.

As a rule, each important agricultural legume must have its own particular species of bacteria.

In general agriculture in Illinois, whether it be grain-farming or ordinary live-stock farming, the growing of legumes is absolutely 


\section{THE NEW EARTH}

essential as a part of any economic system which shall maintain the fertility of the soil; and for the successful growing of legumes the presence and assistance of the proper species of nitrogen-gathering bacteria are also absolutely essential."

While other methods of restoring depleted soils may not at once be abandoned, and while sensible rotation of crops will still be followed, yet enough has already been demonstrated to show that soil inoculation is preëminently practical, although before successful inoculation can be secured all other essential conditions of the soil must be supplied. Soils, like gold mines, are liable to become exhausted after long working. For a number of years, like the mines, they may yield a large income, for several years longer they may pay expenses, but there comes a year when the farmer, like the gold miner, cannot make both ends meet out of the profits of his investment. Here, however, the likeness ends,- the farmer, unlike the miner, may put back the gold into his acres.

Artificial nitrogenous fertilization in a sense is like the miner's restoration of his mine 


\section{SOIL INOCULATION}

by means of other gold-at the best, a makeshift. Restoration of nitrogen through bacterial agency is simpler than fertilization, more sensible, natural, wholly feasible, immeasurably cheaper. It is one of the most significant contributions the New Earth has made to man.

While it is a wonderful act, this creation of a soil to fit a plant, it is a still more wonderful thing to create a plant to fit a soil. 


\section{CHAPTER IV}

\section{BREEDING NEW GRAINS}

THERE is something distinctly alarming 1 in the thought of a period of world starvation slowly but surely and relentlessly approaching, when the earth will not be able to support the race. Some who have noted the steady wasting of the soils where cereals are grown each succeeding year in a new country, resulting in a gradual reduction in the yield of these crops from the first year's yield upon the virgin soil, have predicted this period, not so very far distant, either,- a time when there would not be enough bread to go around. Some of these predictions have come from high authorities.

While enough has been developed in the restoration of worn-out soils to show that such a period as this must be so long postponed as to remove it from the need of serious consideration, still more has been demonstrated in the creation of new wheats and corns to take the 
place of old and unsatisfactory ones. 'The creation of new and better cereals, one of the master acts of the men of the New Earth. has not been effected primarily for the overthrowing of the arguments of the alarmists, but such creation does, nevertheless, to a great extent refute their arguments. 'These improved cereals have been successfully made; they are now in actual service. They show us that we are still in the minimum stage of the development of our resources, that the earth has not yet reached the shadow of its maximum of food production.

The creation of a new wheat or corn having greater nutritive powers than the old established varieties, capable of better withstanding drought and disease and insect pest, bred to produce a larger yield per acre than the thriftiest rival in the fields, - such an act as this is alone sufficient to overthrow an army of alarmists. Such an act as this, even if confined only to the limits of the chemist's laboratory and greenhouse, would, by its immense suggestive powers, be sufficient.

But this work has not been so restricted. It has been carried forward into the actual field of farm operations. New wheats have been 
created not only showing larger yields and as great nutrition in experimental plots; but in the thousand-acre farm of the advanced American agriculturist as well. More than this, wheats have been bred to fit a climate, redeeming vast areas of abandoned land supposed to be wholly unfitted for wheat production.

New corns have been created, far richer in food values, far larger in yield, than the best known types of the past. More than this, corns have been created at the command of man for any one of a series of specific purposes,- to be rich in one element and lean in another, to be suitable for food of man or food of beast. They are, in a word, as much the creation of man as the beautiful vase in the hand of the potter.

All this has not been accomplished in a day. It has not been effected without large outlay of time and energy, It has been accomplished after many and crushing disappointments. To create a new wheat, bringing into life a plant before unknown to the world is a primal act. Select from a race of food-providers two factors unable in themselves, or through the aid of nature, to produce other than a certain progeny; then, setting aside the customs, indeed the laws, 


\section{BREEDING NEW GRAINS}

of nature, compel these two to become the head of a new race,- - does it not suggest something of the mystery of the miracle-makers? For years the wheat crop in the great cerealproducing regions of America has steadily declined in yield, and, where it has not declined, it has steadily fluctuated. Gradually, as civilization has pressed westward, wheat-raising as a chief factor in farm life has been abandoned, until today the vast areas of western Canada are looked to as the last source of wheat supply upon the continent. Even here the virgin soil soon begins to fall away from its huge initial yields. While lack of intelligent farming has had something to do with this, and while the depletion of a once rich soil has been responsible for its share of the loss, yet to these alone cannot be given all the blame.

The wheat is a self-fertilizing plant, preserving its identity through the centuries, never changing to a new form, never reverting to an old type, but reproducing itself from age to age. But it may change in character, the wheat of one season from the same kind of seed may be inferior to that of another season, there may be a gradual loss of food-strength and general 


\section{THE NEW EARTH}

stamina. Just so races deteriorate left long to themselves with no inflow of foreign blood. People who intermarry notoriously within the families of blood, must count on a deficient progeny. Diversity, change, admixture - all have their part to play in the preservation of a powerful people.

'The wheat, however, has no power of choice. It cannot cross itself with another and stronger life. It has no recourse to artificial means by which it may start out fresh upon a dominant career. The wheat flower opens in the dull gray dawn while the world is asleep, drops its pollen upon its own stigma, fertilizes itself, goes on forever reproducing itself while the centuries last. It has been claimed, though the claim has been disputed by scientists, that wheat preserved in a mummy's tomb three thousand years will, when planted, produce splendid grain, and that kernels from the same wheat planted a thousand years from now must ripen the same. However this may be, a wheat in harvest from the dawn of Christianity until this 'present day, would never of its own initiative have changed in type.

But man enters; the wheat is transformed; 



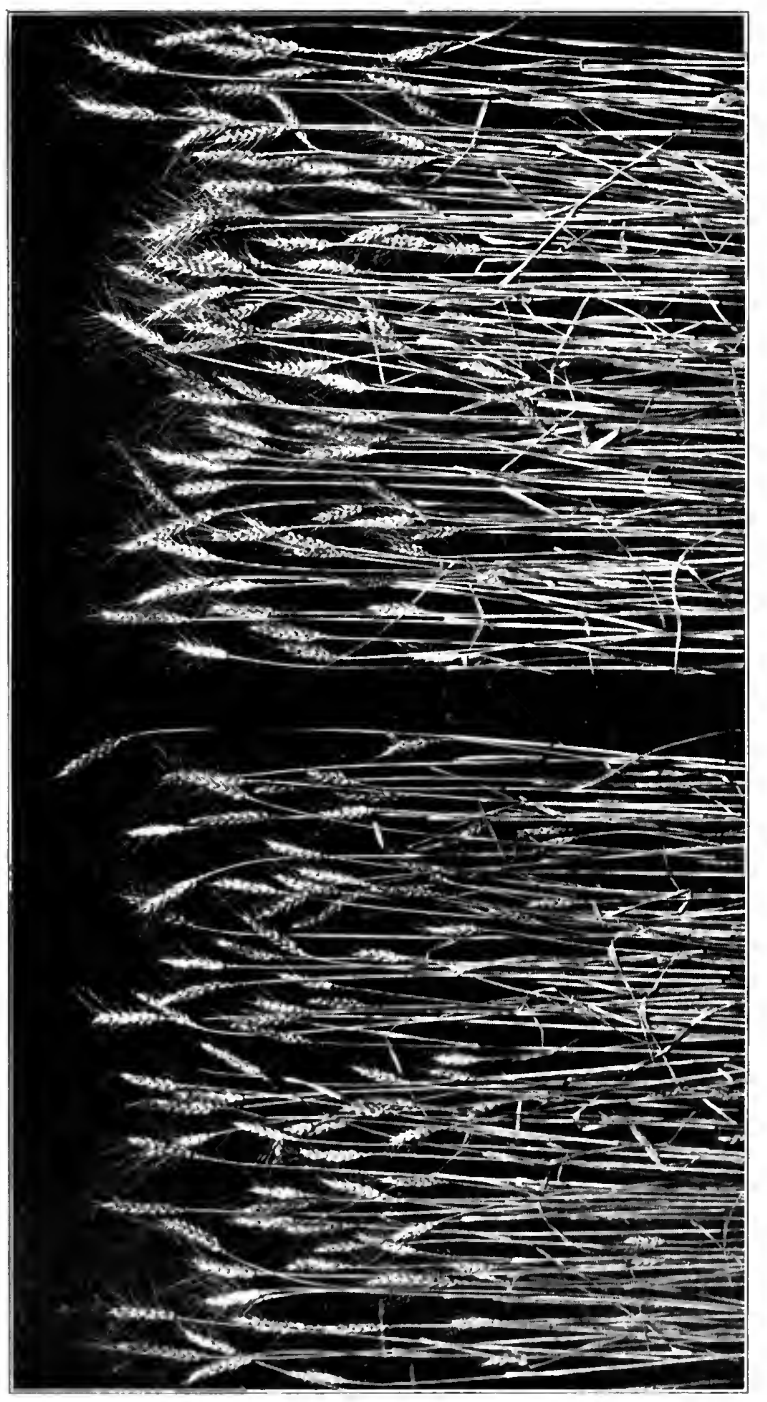

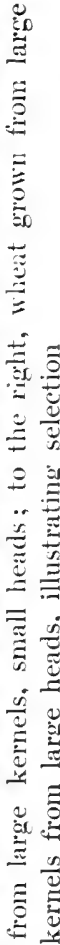


a new and powerful factor comes into the life of the world, - it is the working of a modern miracle, the creation of a new grain, one of the marvels of the life of the New Earth.

'There are two chief factors in the work,breeding and selection. In the early dawn the pollen is taken from the flower of one kind of wheat and placed upon the stigma of another wheat; from them, judged by their past history, a stronger life than either parent should come. It may not so turn out, however, for, out of hundreds of wheats created, by far the larger number are destroyed as not being better than their forebears. When the operator has successfully sprinkled the pollen upon the stigma, he ties up the head in a hood of tissue paper to ward off pilfering birds and insects; the flower itself, as day comes on, closes up and holds fast within itself its precious secret. From the union of the two wheats may come a third of commanding power, one which shall revolutionize the wheat-growing of a continent and become a significant factor in the commerce, no less than the dietary, of the world.

This work of breeding new wheats began long years ago in Europe. 'Thousands of 


\section{THE NEW EAR'TH}

wheats have been made since the first successful test. One seedsman in the city of Paris has produced over three thousand wheats, and I have seen hundreds upon hundreds of these wheats in great cases in the laboratory of this seedsman upon his estate near Paris, not one of them of any value to the world save as it is a record, a proof that no good wheat will be likely to come from the parents from which it descended. For, out of the thousands of wheats which have been created, few have ever been found better than their parents,-thousands have been worse.

It is these few, these individual instances, the one new wheat of ten thousand, which is worth all the years of labor. This new wheat, larger in yield than its predecessors, as rich (or richer) in food, as strong (or stronger) to resist disease, will go on reproducing itself indefinitely, to the end of time; it will not be changed save at the decree of man.

But it is so slow, so very slow in reaching the period when anything definite can be said about it as to its relative value alongside of the older wheats. A new race of wheat begins with a single kernel. 'The first year this kernel 


\section{BREEDING NEW GRAINS}

will produce but a few grains. 'These must be gathered from the single hill with the utmost care and only the best ones kept for future tests. All through the life of the succeeding kernels from the parent wheat it is a constant succession of selections. Another year must elapse before the tiny harvest of this one kernel of wheat may be garnered,-it is still a fairy's harvest. But year by year it grows until at last it passes out of the realm of the fairy,-it has become the get of a giant. Perhaps at the end of ten years there will be enough of the new wheat to plant the twentieth of an acre; then the progression beconies far more rapid, the results more tangible.

But, before this period is reached, it is far more than likely that the experimenter has found out that the new wheat is no better than the old, no larger in yield, no stronger to withstand disease, no richer in food than the parents from which it sprang. Indeed, more than this, he may find that the new wheat is far inferior to the old, and all the years of patient study and care have gone for naught.

Other wheats, however, at the same time, have been traveling the same road up through 


\section{THE NEW EARTH}

the decade, and possibly, out of them all, one will be found better than the old. It is this one which is so eagerly sought, for which no sacrifice of time and patience is too great. All through the years, the life-history of the wheat is noted with the utmost care. Each wheat, and its progeny, is kept separate from all others. Every event in its life is recorded in a specially prepared book. Its yield, figured out with mathematical precision in acre measures, its weight, its color, the character of the food stored up in its brown kernel, the height of the stalk, the depth of the root, the manner in which it has withstood, or yielded to, the attacks of disease,- - all these points and others must be recorded with infinite pains; at no place may there be a missing link in its history.

Breeding and selecting go hand in hand in the work. The selection consists in preserving only the best,- -it is a rigid system of exclusion, by which the poorer wheats are constantly eliminated. It begins with the kernels, only those of the choicest types being preserved. It continues all through the growing of the wheat into the harvesting, so that at the end of a given test the wheat comes forth a fine 


\section{BREEDING NEW GRAINS}

example of the survival of the fittest by means of man's direction. The utmost care is taken to make the wheat strong at all points. Not only must it be better than its ancestors in point of resistance to disease and in increase of yield, but it must run the gauntlet of the sererest chemical and milling tests in order that its food value may be determined. If it fails here, it is discarded, no matter how much it may be otherwise better than its forebears.

From the investigations and tests which have already been made, it appears evident that the wheat yield of the entire world is to be increased enormously, in the aggregate, by this creation of new wheats. In many cases, when the new wheats bred for the hard wheat regions of the Northwest have been given actual field tests, the results have shown gains of from two to five bushels per acre; often the yield has been much greater. In instances, the new wheats have averaged as high as fortyseven bushels per acre, while the average yield of the old wheats alongside them and throughout the states of Minnesota, and North and South Dakota has been from twelve to fifteen bushels per acre. In the days when the soil of 


\section{THE NEW EARTH}

the northwestern states was virgin, before exhausted by successive wheat cropping, the average yield was frequently close to the highest now shown by the new wheats. One of the new wheats, which has for years been under test in the State Experiment Station of Minnesota, where very important work has been done in this line, has now, 1906, been distributed so thoroughly as to cover at least a million of acres, another wheat covers nearly a million acres, and still another, all bred at this station, approaches a half-million acres. It is estimated that these new wheats, together with new and improved varieties of oats, barley and flax bred at this station, will, ere long, cover nearly or quite twenty millions of acres, adding several dollars per acre to the yield of the crops. 'Two thousand new hybrid wheats are now under test at the Minnesota station.

If the wheat crop of the United States alone should be increased by but three bushels per acre, at least one hundred millions of dollars per year would be added to the national wealth, while the world at large would be richer by about five hundred and sixty millions of dollars per year with the same increase. 


\section{BREEDING NEW GRAINS}

The actual demonstrations upon farms where the new wheats have been raised take the matter out of the realm of conjecture and theory.

In some ways, still more wonderful than this has been the breeding of a wheat to fit a climate. In portions of the South there are large areas which have been held to be unfit for wheat production. They were wheat-lands to all intents and purposes, but they had sadly deteriorated. In the state of Tennessee the wheat production had fallen in 1900 to about eight millions of bushels on something like a million of acres of land which ought to have been yielding wheat. 'The trouble was there was no wheat which would grow upon this soil and produce good results.

At the experiment station of the university of the state it was determined to breed a wheat which should fit the climate and soil. After years of study into climatic and general weather conditions, after years of testing, breeding and selection, a wheat was produced which, instead of the usual average of eight or ten bushels per acre upon the supposed-to-be infertile soil, has produced as high as forty- 


\section{THE NEW EARTH}

eight and one-half bushels per acre, while maintaining an average of over thirty-seven bushels for a period of four or five years. The influence of such a factor as this upon the agricultural life of the commonwealth, as well as upon other states having similar stretches of long-idle soil, is very great. It points the way to a reclamation of large areas of abandoned wheat-land, thus adding enormously to the state.

Turning to corn, the greatest cereal in point of value of annual production in the United States, the results achieved are fully as significant. In corn the work has been carried on mainly through breeding by selection. 'The corn is not a self-fertilizing plant, like the wheat, but is pollinated by the wind and insects bearing the enriching pollen from plant to plant. 'The results which have been here reached are hard by the border-land of miracles.

'The object sought in breeding new corns was not only to produce corn with a heavier yield, but to change the character of the corn itself. Corn for human food should be rich in one element Corn for manufacture into any 


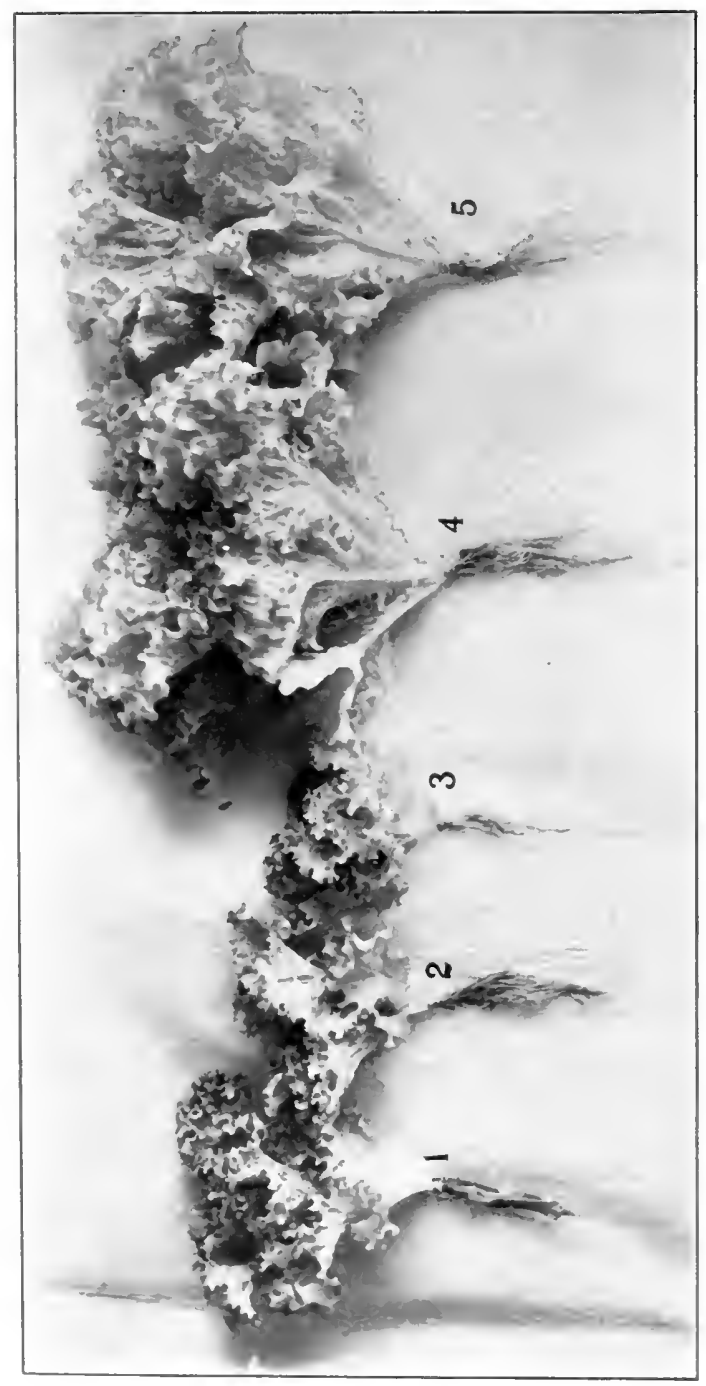

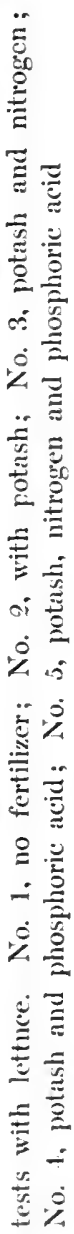

恼 



\section{BREEDING NEW GRAINS}

of the various products which are now made from it should be rich in certain other elements. So the corn kernel was studied in order to find out precisely what it was made of; then by breeding it should be changed. By taking kernels from a series of ears known to be rich in one particular element, and breeding from these ears year in and year out, carefully selecting for future seed only the richest and best kernels and only those approaching the ideal established,- - so, little by little, with infinite pains and patience, new corns have been built up, having an entirely new chemical composition, or, better put, having a different ratio between elements.

A manufacturer would like a corn made for his uses. He would be making, we will say, corn-oil, now one of the most valuable products of the corn plant. It is in large demand among the olive-oil manufacturers of Europe; and while it is not comforting to think that the integrity of so common a food as imported salad-oil should thus be brought into question, it is yet satisfying to know that so large an amount of the imported article may have been in America before as corn-oil, pronounced by 
those interested a wholesome vegetable oil. The oil comes from the fat in the tiny germ of the corn, and the larger the germ, the greater the supply of oil. Quite a number of other avenues are open to the corn-oil, and it appears to be but at the beginning of its commercial life. In the course of a few years, after having first made a searching study into the life of the corn, Prof. C. G. Hopkins, of the Illinois Agricultural College, bred a new corn which was relatively much richer in oil than any which had preceded it. He produced a corn having six and ninety-six hundredths per cent of oil, while the oil in the corn of the crop with which he started six years before contained only four and seven-tenths per cent of oil. To some manufacturers the fat of the germ is not essential, so, to accommodate these, he reversed the process and bred a corn low in fat, or oil, reaching two and ninety-nine hundredths per cent. As every per cent of fat in corn will increase the value of the corn for those manufacturing the oil by at least five cents per bushel, the immediate commercial importance of the new corn is apparent.

'The clement of the corn which is most valu- 


\section{BREEDING NEW GRAINS}

able for strengthening food, the protein, as it is called, which is the muscle-building material of all food, has also been increased at will, and, where it could make way for some other element suitable for some other purpose, it has been decreased. All this has been accomplished by selective breeding. Corn has been produced having sixteen and eleven hundredths per cent of protein, - a remarkably large amount,- while the protein has been reduced to six and sixty-six hundredths per cent, a difference in protein of nearly ten per cent. Corn is also bred for a large amount of starch and similarly successful results follow. The corn in the hands of the scientific man becomes a miracle plant.

Along with these changes to suit the demands of man has come a large increase in the yield of the corn. It is likely that this increase will be fully ten bushels per acre,- - an increase which would add to the national wealth more than four hundred millions of dollars per year.

Perhaps in no department of the New Earth have the practical and the theoretical been so intimately interwoven as in the production of 


\section{THE NEW EARTH}

new wheats and corns. These two cereals upon which the world depends for so much of its food, food for man and food for beast, come into very intimate relations with life itself. Whatever lifts them, whatever strengthens them, whatever surrounds them with safeguards, is of practical value to the race; whatever increases their productivity and at the same time maintains their food value, adds enormously to the welfare of the race.

Much concerning their development is still shrouded in mystery. Much yet remains to be done. Even those who come into closest touch with those grains in this their wonderful service to the race are baffled when they contemplate the possibilities of plant life in the mass. The greatest mystery of all is life itself, but we shall find in the sweep of the influences of the New Earth that the life of the plant world is more understandable now, more easily handled, so to speak, than it has ever been before since the world began. The development of the plant through all its varied history from sprouting time to harvest is of surpassing interest. 


\section{CHAP'TER V}

\section{PLANT DEVELOPMENT}

Flower in the crannied wall,

I pluck you out of the crannies;

I hold you here, root and all, in my hand,

Little flower-but if I could understand

What you are, root and all, and all in all,

I should know what God and man is.

-Tennyson.

IN passing from a consideration of the crea1 tion of a plant to fit a soil, it will be of interest to note the recent developments of, and additions to, the world's knowledge of plant life itself, and to indicate something of the store of knowledge to which the tiller of the soil of the New Earth may now go for assistance in carrying forward his work. In comparison with some other of his activities, man has been painfully halting and backward through the centuries in his investigations in the realm of plant life. Indeed, even now, when the life of the New Earth is bursting into blossom, the layman is constantly surprised at the differences in opinion expressed 


\section{THE NEW EARTH}

by those who should be united on all essentials, and at the rapid proving and disproving of laws and theories. While there is a whole literature on plants and plant life, one is not at all certain today what may happen before tomorrow morning. Science to the layman is, after all, a good many times a misnomer; very much of so-called science is only empiricism, a process of testing, a very interesting and honest and absolute quackery. To know today should be absolute, but to know today very often is to deny tomorrow, and to try and humbly forget the day after. There has ever been on the part of some who have sought honestly to add to the world's knowledge a painful facility in jumping at conclusions and then abandoning them. Not that a mall should not admit errors and hasten to change,-that goes without saying; but when he adopts science as his patron saint he must bear well in mind that science implies, nay, demands, to know.

And yet, while much that has been developed has been abandoned soon after birth, vast progress has been made. 'The plant life of the world is unfolding its secrets as never 
before; or, better put, man is rapidly coming to a sensible knowledge of these secrets and is setting them out in orderly array.

One day, in a long, sunny room overlooking a beautiful bay and a seacoast town with the lavender mountains beyond, I looked down through a microscope upon one of the most marvelous sights the human eye may ever hope to see,- the actual creation or reproduction of a life. But a few moments before, one of the laboratory workers had called me to see a low form of minute life which had been brought up from the abyssal depths of the sea. While I looked, the cell life became animate with motion,-a tiny globular mass, moving now here, now there. The inner protoplasmic life, if you so wish to call it, was vibrant with a coming change,-the eternal triumph of creation. The greatest act in all the universe was being performed, for, even as I looked, a sharp, distinct line cut its way down through the quivering egg-shaped mass; it left two living things where there was but one before; a new life had come to the world. It was not only a marvelous thing thus to see life in the act of creating other 


\section{THE NEW EARTH}

life, but it was a vantage ground from which I, a layman, might get some view at least of the commanding outlook of the true modern science. It was made possible that I should see this wonderful thing solely because of the men of science who have been giving their lives to the study of the phenomena of life. Here it was biology that was uppermost; and all around the globe where the seas give up their great secrets men are at work searching for new facts and old truths. Other men, a growing host, are searching for the secrets of the plants on which man depends for his protection, for his sustenance, for his very life. Both these groups of men, and others in diverse but still allied lines, are hastening the day of a completer knowledge of the New Earth.

It was not so many years ago, as the centuries move, since the plant life of the world was hidden behind an apparently impenetrable veil. Beyond this lay a region of darkness largely unexplored and unmapped,--a region toward which man had sometimes moved in some crude attempt at exploration, but from which he had always returned with but little 



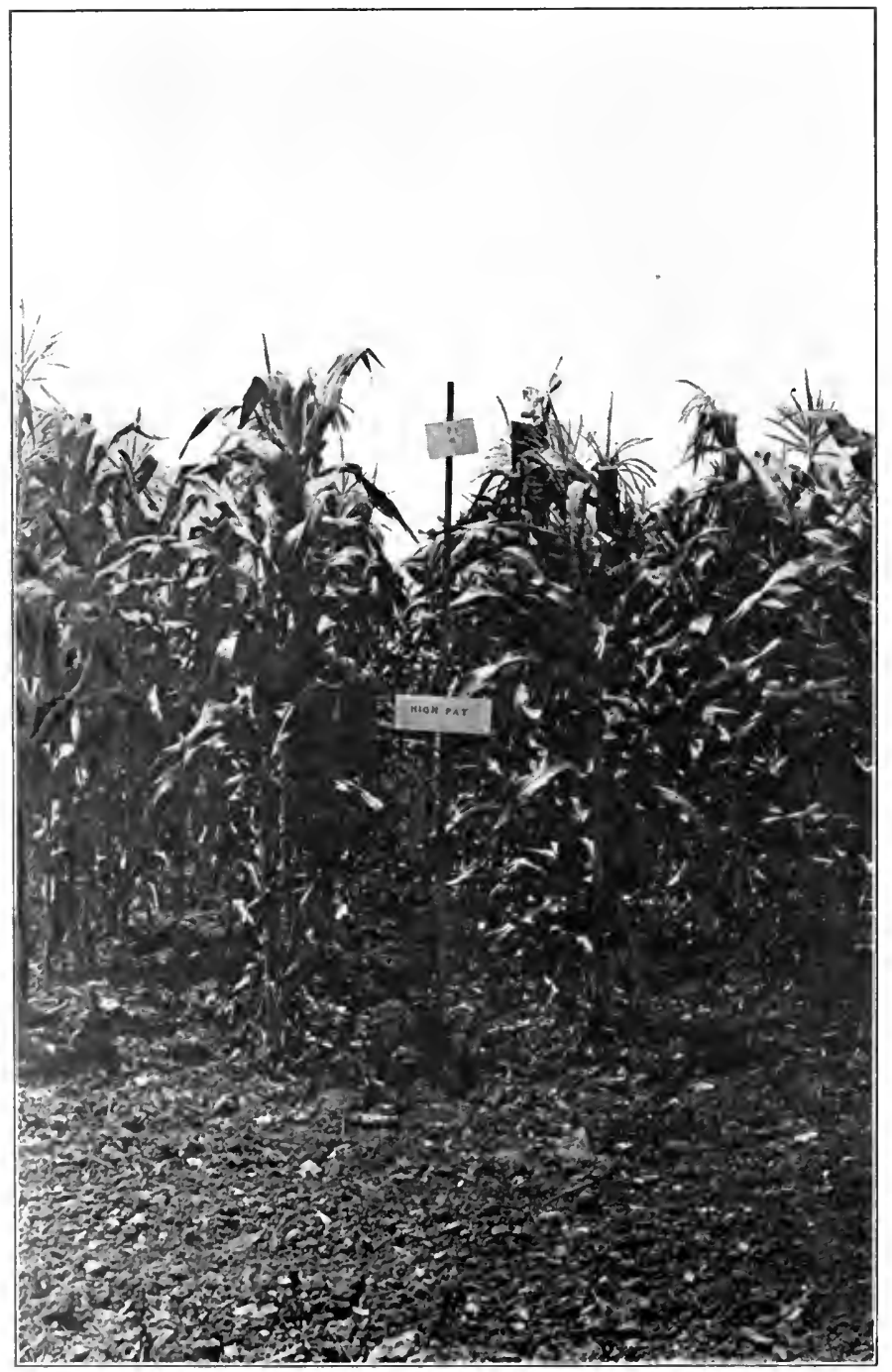

Field of corn bred to produce a high percentuge of fit, or oil 


\section{PLANT DEVELOPMENT}

to show for his pains. When the literature and art of Greece and Rome were at their height, something like five hundred species of plants were known and described. When the revival in learning set in, in the Middle Ages, this number had only been doubled; while in 1583, when Shakespeare had nearly reached his majority, only fifteen hundred and twenty plants were known, divided into some fifteen classes. In 1700, under the great impetus of Linnæus, father of modern botany, the number had increased to eight thousand, while today more than two hundred thousand plants are known, named, described and classified. There are fully fifty thousand species of cultivated plants alone, embracing thousands of varieties. Even as late as the sixteenth century, most plants were valued chiefly for their known or supposed medicinal qualities. The shape or color of a plant often determined its supposed curative value, as in the case of the hepatica or liverwort, the resemblance to the liver found in its leaves marking it in the mind of the doctors of that day as peculiarly helpful for liver complaints.

Under the light which has developed in the 
study of the New Earth, the tiller of the soil may come into closer relationship with nature than ever before since the creation of the world. Not only may he know more of the secrets of the earth and their bearing upon his life and work, but he can, at the same time, measurably add to his own wealth by taking note of what these discoveries suggest.

Today he may know that the plant which he rears is not merely a blade of grass, or a stalk of wheat, or a succulent vegetable, or a protecting tree, but that it is an intricate and subtle organism, not so highly constituted nor so diverse in its powers as his own, but still possessed of a most delicately established individuality. He may look at a wheat plant, for example, and, seeing upon it certain yellowish spots, know that it is lacking in lime and that lime must be fed to it. If he follows the experiments of some of the scientific men, and keeps his pigeons on food that is scant in mineral matter, he will see them die on his hands; while if he feeds his dog on meat long macerated in water, so that the mineral portions are leached out, it is more than probable he will find the animal some morning rapidly 


\section{PLAN'T DEVELOPMEN'T}

developing strange nervous symptoms, and finally, unless supplied with food which contains mineral support, dying with spasms and suffocation. All manner of minerals go to the manufacture of plants,-lime, magnesium, potassium, sulphur, iron, salts, aluminum, even copper, lead, antimony, zinc and arsenic. Some plants, indeed, thrive in soil which is rich in lead and zinc, while certain pine trees which had their roots in a copper soil were found to have taken up so much copper that it made up one per cent of the whole dry weight of the tree. It will be found, too, if he can carry his investigations into various lines, that silica lies in the leaves of the plants, just as it lies in the quartz of the mountains or in the deep lustrous depths of the opal. He will find that when the summer is waning a strange procession is in progress in the trees, as the substances which have been keeping the leaves green and fresh begin their backward journey to the body and roots of the tree, there to be stored up for the next season's service. Indeed, as one writer has shown, this removal of the food supplies of the leaves begins while the fruit is ripening, the 
starch and sugar as well as the life principle itself, the protoplasm, traveling backward to give their enrichment to the fruit,- color and texture and food value. Little by little, too, the tree is forcing its leaves to die. It forms rings of separation tissue, so to call them, layers of cells in reality, at the base of the leaf, at last so nearly cutting it off that it falls of its own weight or is blown off and sent scurrying along the dry ground by the swirling autumn winds. A German writer, Kerner, discussing the subject and noting the withdrawal of the protoplasm, starch, sugar, and so on, from the leaf-blades says:

"In this way the plant suffers only the slightest loss in the material manufactured by it in the preceding vegetative period; for the leaves, from which everything useful has been transported into the stem structure, now form nothing more than a dead framework, and their cell chambers contain only small yellow granules, together with crystals and calcium oxalatc, which cannot be employed further and are of no more use. 'The shining yellow granules which are found in the cells of fallen leaves, and to which is due the yellow coloring of the 
autumn foliage, are to be regarded as the ultimate useless residue after the withdrawal of the transformed cholorophyl corpuscles."

He calls attention to a coloring material in the leaves named anthocyanin which serves a very curious purpose, keeping itself between the food particles that are traveling back to their winter home in the trunk and roots of the trees, thus forming a screen or awning, as he calls it, between the foods and the sun, a protective agent against injurious light rays. Certain acids combined with this coloring material produce the various colors of the autumn leaves, the coloring material appearing in great abundance when the leaves have about ended their life.

The green color of the foliage, which is caused by the chlorophyl he refers to, takes on a new and vital interest in the light of modern days. It comes to the farmer with a strange sense of unreality,- - this thought that the green of the splendid sweep of the waving corn is practically that which keeps his own lungs in action, for it is from the iron compounds that the chlorophyl is in part produced, the green of the fields and forests, just as it is 


\section{THE NEW EARTH}

the iron that in a certain form produces the part of the red blood which carries the molecular oxygen to the remotest part of the body and keeps life in poise. So, between the blood in his veins and the green of his fields there comes a close and strange intimacy.

And how insistent are the plants that they be fed on minerals! An acre of wheat, it has been shown, will use up ten pounds of lime in coming to maturity; an acre of sugar-beets, thirty-three pounds; ordinary grasses, fifty pounds ; clover, one hundred pounds; while an acre of tobacco is not satisfied and best adapted for the solace of the pipes of man until it has consumed at least one hundred and thirty pounds. A wheat plant was once kept alive in a chemist's laboratory for several weeks without being fed any lime. It had all the other foods, but it slowly sank in the scale. Little by little it used up all the stored-up lime in its body, and then, when the end seemed near and it promised to die of lime starvation, the long-withheld food was administered to it and in a little more than five hours, so great the miracle of plant growth, it began putting forth buds. 
But it is not only in the vital essence of his body, the blood, that the farmer may find likeness between himself and his plants, be they flowers or fruits or waving grains. 'The searchers for the secrets of the New Earth have disclosed to him that the bones of his own body and the framework of his plants are both dependent upon the same substance, the lime which gives skeleton to both. For the cells of the plant in which go on the wonderful processes of plant growth demand lime, in addition to other substances, for their construction and maintenance, just as man demands it for his own frame,-without it both collapse.

More and more as the man comes to study the plant, he discovers strange likenesses between himself and it. He wishes much for something,-it may be a wider education for his children than he has himself had, it may be that beautifully lying piece of meadow-land beyond his borders, which he has longed for these many years - he wishes, but he does more, he acts, and acts with prolonged persistence until he reaches the end sought. In a humbler, but not less persistent way, the roots of a plant follow in the same path. 'The tip of the root is 
supplied with a cap, or sheath, for service in pushing out into the earth region around, in search of water and nutriment, and yet so delicately supplied with what we might call nerves that it instantly detects an obstacle it cannot penetrate and goes around it. It has power as well as persistence, too, and a single tiny root end forcing its way through the earth exerts a power equal to three hundred pounds pressure per square inch. Like the man, it does not give up until it reaches its desired end.

'The root-system of the plant has been called very fittingly its anchorage, since it not only is constantly being extended as the plant seeks more food, but serves as an anchor to hold the plant in place upon the earth. It also serves as a storage place for food for the plant, laid up for future use. The ramifications of the roots of plants naturally vary, but a single squash seed has developed a plant having roots several thousand feet in length. Instinctively the roots turn away from the light. 'Their work, like that of the bacteria in the nodules of the clover, can best be carried on in utter darkness. 'The value of a root as a storage reservoir cannot well be better shown than in 


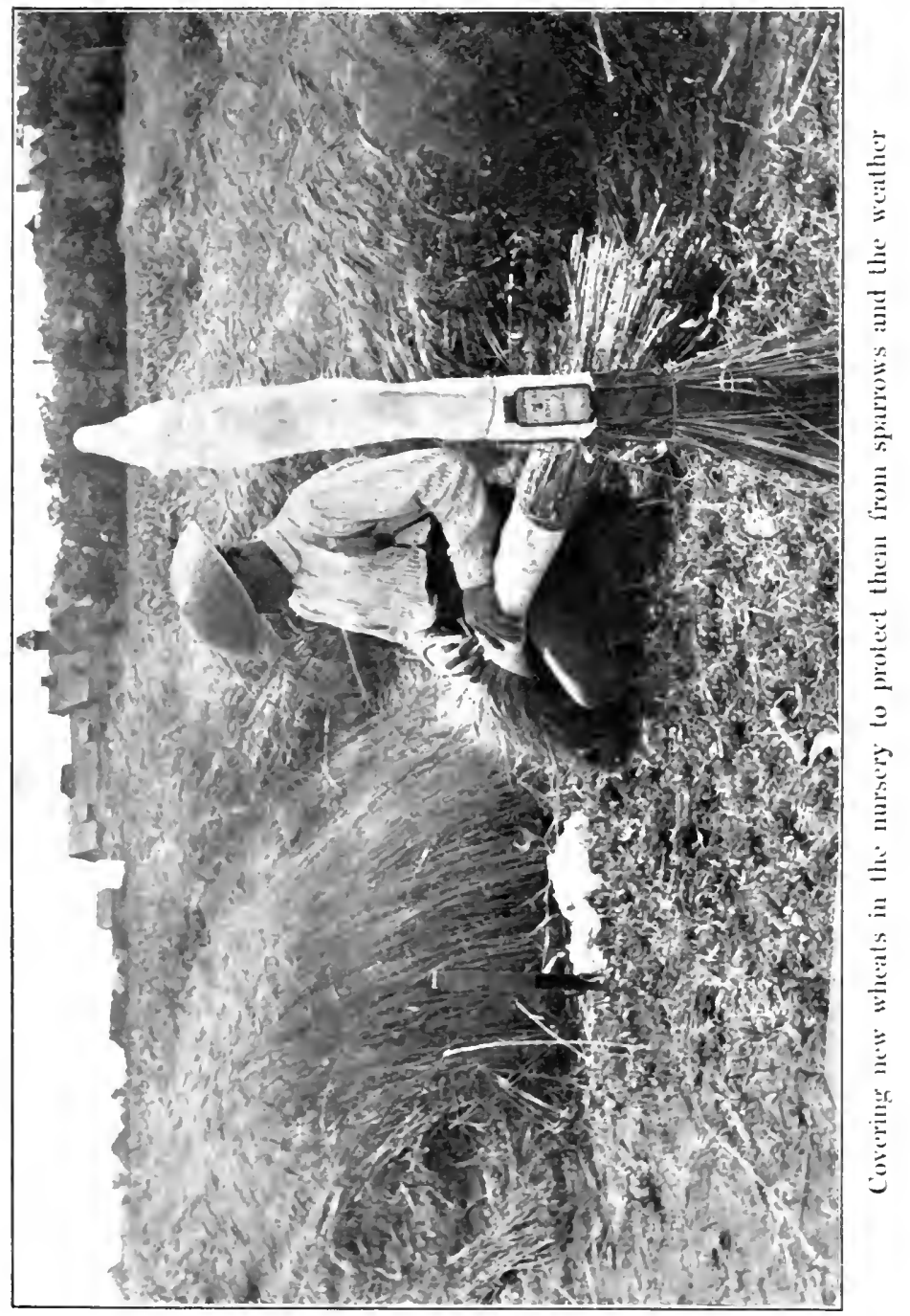



the case of the sugar-beet, which contains from eight to twenty per cent of sugar, besides other solids in smaller quantities.

And here, again, as he looks at the structure of the plant, the New Earth man finds constant similarity to himself. As his body stores up food against which he may draw in days of sickness, so the plant stores up food for its own uses. While the man is able to take the initial steps toward supplying himself with food, an act of the will, if you please, yet the plant is not so far behind the man after all, for it also takes constant care that its food supply does not run low in the larder. Man is as dependent, too, upon favoring conditions of soil, climate, sunshine, air and rain, as the plant is; without them the plant dies, and when the plants of the world die, man dies.

Above the roots of the plant the great work of food manufacture and assimilation goes on, day following day adding to the plant's strength and day following day adding to its stature until, like man, it reaches a stage of maturity and passes on to old age and final dissolution. But just as man in these later days is studying how he may prolong life, and 


\section{THE NEW EARTH}

doing it, too, by means of better foods, improved methods of living, better sanitation, and so on, so nature is on the lookout for longevity as one of her attributes. The great trees of California, oldest of living things upon the earth, more than two thousand years old when came the dawn of Christianity, - these gigantic plants of immortality, are attesting through the centuries that life may be prolonged far beyond the so-called natural span.

One of the foods upon which the plant depends for its strength is, per contra, a poison to man. It is a gas, carbon dioxide as it is called, or, in commoner phrase, carbonic acid gas. It exists in the atmosphere in the relation of one part to every twenty-five thousand. While it is harmless as an aërating agent, giving a certain pleasant pungency to various drinks, it is poisonous when taken into the lungs. It is that which makes rooms illy ventilated so dangerous, for the gas is constantly given off from the lungs and, in a closed room, is breathed over and over again, a slow but persistent poisoning.

'The plant has a better, or at least a diffërent way of doing things. By day it takes up 


\section{PLANT DEVELOPMENT}

the carbonic acid gas from the atmosphere, separates the carbon and oxygen which compose it, utilizes the carbon for its own food, and sets free the greater part of the oxygen. $A$ beneficent friend to the plant, the gas is an enemy to man. Owing to its weight it easily settles down in low places, and, when formed in large quantities, makes the deadly blackdamp or choke-damp of mines and caves. It is estimated that a single person throws off two pounds of this gas a day.

It has been feared by some that, under certain conditions, a great danger might come to the race through the supply of this gas, which even under normal conditions is given off in the air about us in enormous quantities. Scientific investigation has shown that though the whole human race, together with the lower plants and animals, give out six thousand million pounds of carbon dioxide every twentyfour hours, the plants of the vegetable kingdom consume each day more than twice as much as this, while giving out to the air twice as much oxygen as they consume.

In a peculiarly fitting manner the plant may be termed a pump, as well as a highly organ- 
ized individual, for by means of its root system it draws up from the earth large quantities of water, uses it for its own purposes, and sends it off again through the air by transpiration. A single poplar tree of normal size and in good health sends off through the air every day a barrel of water. It has been found that gas in trees plays a most important part in this act of pumping. Maple-sugar trees, for example, have been carefully tested by the specialists in the Vermont Experiment Station by means of pressure gages. It was shown that the gas in the tree is at times in a state of suction through being highly rarefied. This draws up the sap from the roots-it is not forced up from the roots, as had long been believed. There is root pressure, however, and the man of science comes forward with the information that the dew which makes the grass brilliant as with many diamonds when the sun is coming up is not dew at all as we commonly call it, a product of condensation, but water which has been drawn up from the roots in the night and, there being no sun or warmth to dry or evaporate it, it has formed in drops upon the grass-blades. 


\section{PLANT DEVELOPMENT}

But in and through all the life of the plant, whether it be the tiniest flower that blossoms but for a day or the vast pine that outlives civilizations, there runs the influence of another power, the highest attribute of its life, its protoplasm, its very life itself. Different substances enter into this protoplasm, and it has an exceedingly complex chemical composition, though, roughly speaking, it is about eighty to eighty-five per cent water and fifteen to twenty per cent solids, with small quantities of fat and mineral salts. It is maintained in a cell,-from it comes life itself; when it dies the plant dies. It has the power of combining the food elements and producing all of the organic compounds of the plant. The word is Greek, in its origin meaning the first creation, or the first creature or thing made. In plant or animal it is the basis, the source of and continuity of all life.

It may be analyzed and described; but there man's sight ends, there his hand is stayed. What gives it its life lies beyond his vision in the realm of the infinite. In his own life he can understand his physical powers and forces in large measure, he can care for his body as 


\section{THE NEW EARTH}

he cares for his grains and his fruits, he can nurture and control and educate his higher faculties, just as he can, by exhaustive breeding and selection and combination, lead the plant life about him to higher planes, augment it, ennoble it, improve it, enormously multiply it. But beyond all this, beyond his life, lies his life. He stands before his life as he does before the protoplasm cell which he may see under the microscope, or as he stands before the life which has been brought up from the abyssal depths of the sea, and watches it as it reproduces itself; but between this protoplasm and between this act of re-creation and life itself lies a gulf as wide as eternity,-a gulf upon which no man may even so much as raise anchor while earth life lasts, but which, through all the centuries since man and the plants came upon earth, he has been crossing under the white sails of an immortal hope. 


\section{CHAPTER VI}

\section{THE ENEMIES OF PLANT LIFE}

THE fact that Nature generally preserves 1 a strict balance in the administration of the affairs of her many types of life has had an important bearing on one of the vital activities of the New Earth. Nature believes in legitimate competition. She believes, too, in the survival of the fittest; but under normal conditions she preserves a splendid neutrality, urging only that each factor, plant, or planet, or man shall do their full duty. It is not Nature's way to permit maleficent monopoly, though she encourages legitimate organization and looks favorably upon competition. It is her way to see that no one factor gets the upper hand. We need not follow this line into the realm of the theorists who see in wars and the plague a necessary, and sometimes insufficient, bar to over-population; for here there must, of necessity, be indefiniteness and speculation. If there is any one thing that 
distinguishes the New Earth from the Old more than another it is preciseness; the New is not speculative, but demonstrable and intensely practical. While it is at times spectacular, or even dramatic, it never departs from the bounds of common sense.

'The balance of nature is in no way more interestingly shown than in the disposition of insect pests. Nature not always goes to the full limit of service unaided; she frequently must have man's help. Sometimes she is sore beset by enemies; so sharp and bitter their attack, she seems unable to withstand. 'This, now and then, is shown in the sudden uprising of insect pests, sweeping all before them, as in the case of the locusts, and, for the time being, rendering even man helpless before the fury of their attack. No one who has ever lived in the path of the grasshopper, when he comes with his myriads of cohorts to defoliate the world, need be told how terrible is his progress: he is to the green earth what the Plague is to man. 'To hear the roar of uncountable wings, to note the looks of apprehension in the faces of the elders, to see the whole earth stripped of its green,- - tree and 



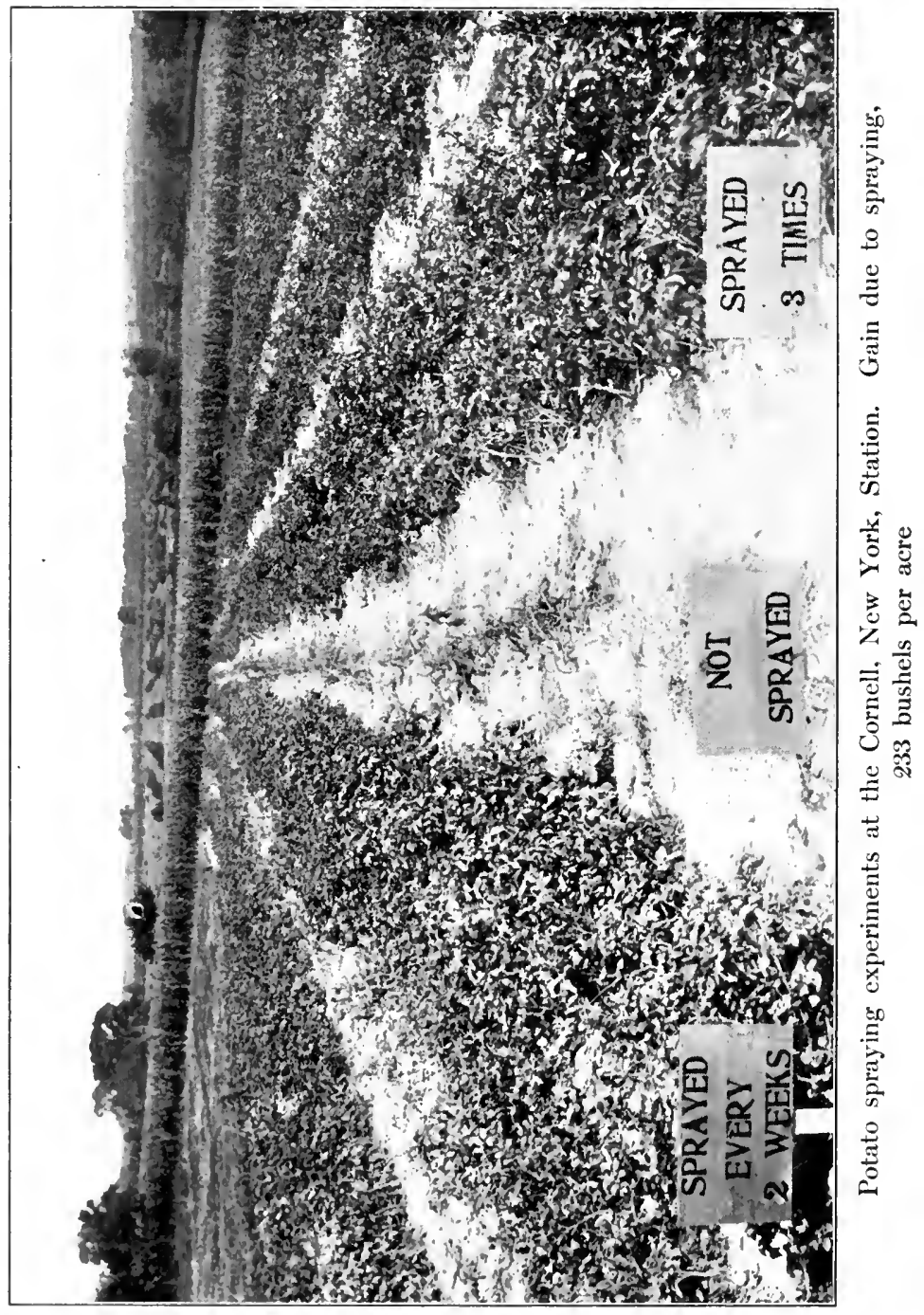




\section{THE ENEMIES OF PLANT LIFE}

shrub and fields of waving grain,- to realize that the grasshopper means death to the crops and death oftentimes to hope,-it is an experience not easily to be forgotten.

In general, the insect pests which now and then upset the wholesome balance of nature are of two kinds, - those which make their home in the plant itself, the plant acting as the unwilling host of the pest, and the exterior ones, so to call them, the insects which prey upon the plant from without. Most of these pests are true animal life-flies, mites, caterpillars, and so on. There are, too, pests of another type which now and then arise which are vegetable in character, low forms of plant life - the rusts, mildew, bunt, smut, molds, and the like, diseases, rather than pests, which thrive on decaying vegetation and which sometimes do irreparable damage to growing crops. They are fungous in their growth, rapidly multiplying and carrying decay and disintegration wherever they go. But, for present consideration, we may turn to the insect pests as of peculiar interest, for in their control we have one of the most significant and important advance steps yet taken by those who are 


\section{THE NEW EARTH}

giving their lives to the development of the New Earth.

If the nation were compelled to pay out, say, as a war indemnity, or for some loan incurred through national extravagance or unthrift, a sum equal to the loss now sustained by insect pests, it would arouse universal revolt; and should it be known that the enormous sum was a matter of annual payment, to be indefinitely extended, apprehension of a deep and vital type must take hold on the public. For the losses in the United States in the past ten years through insect pests, without con sidering indirect losses, in themselves vast, have been seven billions of dollars, - an amount more than three times the national debt, a colossal sum even in a wealthy nation accustomed to large figures. And the loss is progressing at the rate of seven hundred millions of dollars a year,-enough to pay all the expenses of the nation, including the pension roll and the maintenance of the army and navy.

'To combat these pests which annually do such vast harm, the ingenuity of man has been taxed to the utmost. Science has come forward with her formulæ and methods. Inven- 
tion has done its uttermost. Millions of dollars have been, and are being, expended. Costly apparatus and large numbers of workmen have made up this expense, to say nothing of millions of dollars lost through ruined crops and orchards. In the state of Massachusetts alone it is estimated that eight millions of dollars have been spent in unsuccessfully combating a caterpillar. The whole gamut of chemistry and invention has been run, and while good has resulted from some of the many washes, sprays, fumigators, insecticides, and so on, they must all be counted as makeshifts at the best-they alleviate but do not prevent.

I quite well remember conversations with one of the best known of the older practical entomologists of the country, Dr. Otto Lugger, since deceased, who had for many years been making a deep study of the subject of insect control. In fact, many years before any public announcement of the prevention of fevers in tropic countries by the exclusion of mosquitos, he had demonstrated the truth underlying while engaged in natural history researches in Central America. He had been 
studying the chinch-bug at length, an insect which for years has done great damage to grains in the Northwest. At last he hit upon a plan which, while not altogether successful in his lifetime, because, for one reason, of the lack of successful coöperation on the part of farmers, contained a vital principle of large significance. He determined to let the bugs kill the bugs, a simple economic advance which is now in a different form going into practical effect. He knew that there was a disease which in certain seasons attacked the chinch-bugs and carried them off with commendable alacrity. He secured this disease in its original form, a low fungous or bacterial growth, multiplied it with great rapidity by laboratory cultivation, sprinkled it in a fine white powder upon the backs of healthy chinch-bugs and set them loose among their fellows, with the result that they at once spread the disease among the other healthy bugs. The disease was then cultivated and sent out in tubes to the farmers with instructions for its distribution. The entomologist died before his work was completed. I do not know that it could have been successfully 
completed, but there was in it the germ of a tremendous force.

In California a modification of this principle is being applied with marked success,- - the destruction of injurious insects by other insects, aiding Nature, when her balance has been disturbed, to restore it to its normal poise, doing that which neither man nor nature could do alone. At intervals, the great fruit industry of California has been threatened through the ravages of some insect. Now and then total extinction of a fruit has seemed imminent. Losses have been very heavy. Artificial protection through sprays, washes, fumigations, and the like, have entailed large expense. Having direct ocean communication with foreign countries where fruits grow in abundance, exceptional opportunities are provided for the introduction of pests by importation. For example, it happened one day that a fruitgrower imported a certain kind of lemon tree which he thought would be an improvement on the local stock, but it proved to be the home of a tiny insect, a scale, very minute but capable of marvelously rapid reproduction. Its mission was to destroy foliage, blossoms 


\section{THE NEW EARTH}

and fruit. The stock was sold to others without knowledge that the scale was on it, and in a comparatively short time, so incredibly rapid was the spread of the pest, the whole citrus fruit industry of Southern California was threatened with extinction. While orange shipments were not then as large as under later development, they were yet steadily increasing so that for the year before the scale was introduced about eight thousand car-loads were shipped. When the scale got fairly at work, the shipments dropped to six hundred cars in a year. Nothing availed. Fumigations and washes were useless. Sprays were ineffectual. Digging up infected orchards and burning the trees, quite as buildings in the path of a tremendous conflagration are dynamited to stay the flames, had no effect, for the pest had now spread to all vegetation and was rapidly turning the country back into the desert from which it had originally been wrested.

At this critical juncture help camc from an unexpected source. A tiny insect, a beautiful little thing, brilliant red in color, not more than the sixteenth of an inch in diameter, one 


\section{THE ENEMIES OF PLANT LIFE}

of the family of ladybirds, became the salvation of the fruit industry of a great state. 'The horticultural commission of the state learned that such an insect lived in Australia and that, where it abounded, this scale was some way held in check. Through the coöperation of Thomas F. Bayard, then secretary of state, a few of the eggs of the insects were secured, brought to the United States, and hatched out. As swiftly as possible the insects were liberated in the infected regions. They proved to be fully as rapid in their reproductive powers as the scale. Instantly upon being released near an infected tree the tiny ladybird searched out the scale and began its work of destruction. It throve on the service, too, multiplying with almost inconceivable rapidity when once the rate of progression was established. It would feed on nothing else but the scale. It was Nature's method of dealing with any factor which threatened permanently to disturb her balance. As it rose to its work the orchards began putting on new life and the fruit industry was saved; millions of dollars' worth of property, present and prospective, owed its existence to the tiny foe of the 
pest. 'The Vedalia cardinalis, as it was called, had won the day, and the ravages of the cottony cushion scale were at an end.

So began one of the most remarkable developments in the many-sided life of the New Earth. The preservation of the balance of nature-it was this which was at the foundation of it all. In Australia the scale and the ladybird were in check, in balance. Neither one superabounded. The moment the balance was disturbed, the scale getting by ever so little the upper hand, that moment the ladybird began its work, keeping at it until foe and pest were in balance. It has been shown that if the eggs of a single codfish should all mature and the eggs of the thousands of new fish should likewise mature and the progression proceed, it would be a matter of a relatively short time before the whole universe from planet to planet and out beyond the farthest star would be a universe of codfish, so rapid and vast the progression. But nature allows but a very few of the eggs to come to maturity - the balance is preserved. It is upon this principle of a preservation of this balance that this California Commission has worked. 


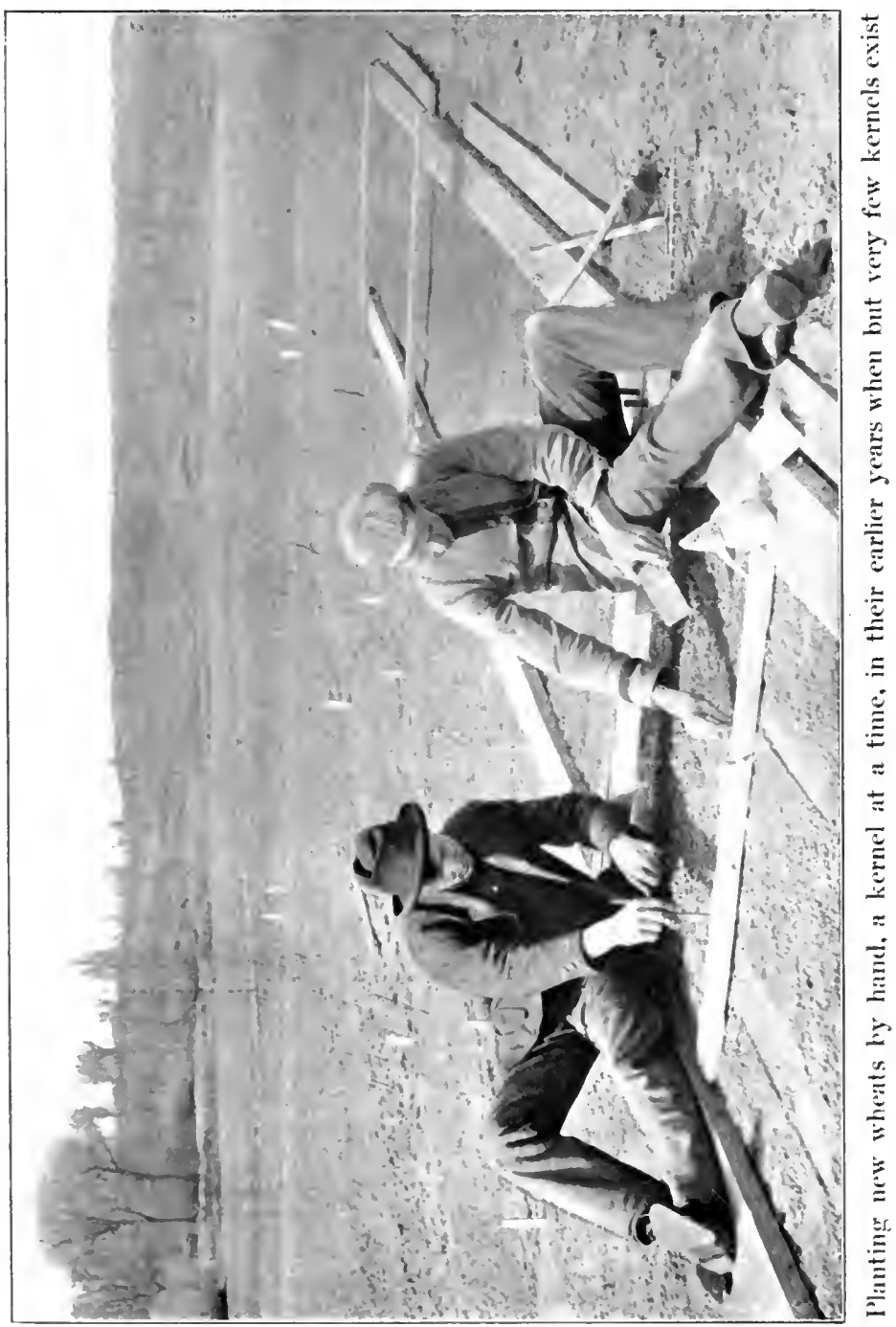





\section{THE ENEMIES OF PLAN'T LIFE}

A skilled man is traveling over the world, jointly in service with this commission and West Australia authorities, seeking for foes of insect pests. He found one day a place in the interior of Spain where the apples were not disturbed to any appreciable extent by the worm which has done such enormous damage to the apple crop in Europe and the United States, the losses in this country averaging twenty millions of dollars per year. This worm is the product of the codling-moth. The worm was found in the Spanish orchards in small numbers, and this led the investigator to inquire why this was, - why the worm did not abound as elsewhere when other conditions were the same. He found in the orchards a small fly, considerably larger than a house-fly and very much larger than the tiny Australia ladybird, very slender and wasp-like in shape, with two pairs of long, blue-black wings. It had also a long sheath in which it carried a slender powerful stiletto. Investigation showed that it was this fly which kept the true balance of nature in the Spanish orchards. It was its particular mission to kill the codling-moth worm, the natural foe of this dreaded pest. 


\section{THE NEW EARTH}

A small supply of the pupæ of the flies was secured and dispatched to San Francisco. In the insectary of the California Horticultural Commission located in that city, they were hatched out into a small colony of the flies. They were supplied with pieces of branches of apple trees bearing the worms. Instantly on discovering the worms they began their work of destruction. The stiletto is so powerful that it can be driven down into the bark when the worm is under the surface, the insect unerringly locating the worm. It finds the worm, kills it, and then lays a few of its many eggs upon the worm's body. Curiously enough, the natural warmth in the body of the worm is sufficient to hatch out the eggs, the hatching requiring but two hours' time. 'The worm thus serves as the hotel, so to speak, for the young flies. 'They live on and in it until they are ready to take up their life-work. When they have reached forty-two or forty-three days of age, they are ready to begin their actual work of destruction. As each female lays several hundred eggs, the rate of progression, where there is ample material on which to feed, is very great. 


\section{THE ENEMIES OF PLANT LIFE}

As soon as the flies were abundant enough, colonies of them were sent out to different parts of California and at once began searching out the worms and putting them to death. Actual work on a scale large enough to show appreciable results was begun in the season of 1905. Favorable reports began coming in to the commission shortly after the liberation of the initial colonies. Indications at once pointed to a condition of affairs approaching similar to that in Spain, the flies so rapidly destroying the worms that it must be a matter of a comparatively short time before the whole state will be patrolled by these tiny protectors guarding the orchards. The extension of the same plan to other infested regions will apparently eradicate this long-dreaded foe of the American apple orchards.

Another pest, a black scale, made its appearance. It promised to be as disastrous as the cottony cushion scale. Investigation disclosed the natural foe of this pest, another ladybird, living in South Africa, black in color and somewhat larger than the tiny red ladybird. From Cape Town branches of oleander bearing the eggs of the foe were sent to San Fran- 


\section{THE NEW EARTH}

cisco. But few of the eggs were hatched out, seventeen all told, and of these only four were females. One of these latter was killed by a spider which had been hidden in a curled-up leaf in the case, leaving but three tiny insects to do battle against a host unnumbered. But the three were equal to the emergency. Each one hatched out many eggs, the greater portion of these eggs in turn hatched out other flies, and soon there were quite a number of colonies ready to be liberated. They began their work in the season of 1905 , wherever the scale was found, and at once the scale began to disappear.

The apricots of the fruit regions of California have been subject to a brown scale which not only destroys the young fruit and foliage, but which forms such thick incrustations upon the trunk and branches as to imperil the life of the tree itself. Other trees, particularly plums and prunes, are subject to its attack. To meet this pest whenever it appears in dangerous quantities, the commission keeps on hand a supply of brown flies, very small in size, smaller indeed than the tiny ladybird, almost microscopic - the foe of the scale. On 


\section{THE ENEMIES OF PLANT LIFE}

report from any region of the state that this pest is appearing, a colony is sent out by the first mail, and soon the balance is restored. Supplies of the infested twigs and branches are gathered along in May. 'This foe is different from the ladybird in its method of attack, eating its way into the parasite or pest instead of killing it from the outside. The twigs are placed in wooden boxes, in the sides of which are glass vials. 'The foe at last emerges from the insect in the box and goes out into the vial. As soon as twenty-five, or more, have crawled out into the vials, the mouths of the vials are closed up with cotton, to prevent the escape of the flies and yet give them air, the vials are placed in stout pasteboard tubes, and thus are mailed to the orchard growers where the pest appears. Colony after colony is thus secured. 'Tens of thousands of them are sent out, and they do their work swiftly and well.

'These foe insects do not in themselves do harm. 'Their chief object is to find their natural enemy, which is the enemy of the fruits. The pest may never be wholly destroyed in a given region, but, by the introduction of its foe and the consequent preservation of the 


\section{THE NEW EARTH}

balance of nature, the danger is eliminated and the foe and the pest go on living together in safety.

'These are illustrations of the work which this commission is doing. Other pests are being subjugated in the same way. When a foe to a given pest is found while the pest is not sufficiently active to warrant operations, the eggs may be kept indefinitely in cold storage ready for hatching when needed. In the insectary of the commission I saw a little orange tree one day about to set out upon a journey which illustrates the scope of the work done and suggests its possibilities. The little tree was possessed of a scale insect which promised serious damage. It had but begun to show itself in California, but it was known to be dangerous. It was learned that in an interior Chinese province the foe to this pest and the pest thrive together with no harm to the fruits, - a complete balance. 'The tree was about to be sent to Hong Kong, where it would meet the agent of the commission who would take it on its long journey into China, place it where it would accumulate on its leaves a supply of the eggs of the foe and 
would then ship it back again, the eggs to be hatched out in San Francisco and the foe liberated wherever the pest appeared.

Strangely enough, so far as now known, each foe must have its particular parasite or pest to feed upon. It is said, for example, that the tiny ladybird that saved the orange and lemon orchards by destroying the cottony cushion scale will starve to death on any other food than the scale;-it would seem that it has been specially prepared for this particular act of destruction.

In order to prevent further introduction of pests, the state of California has established a rigid quarantine against foreign ports in order that no new pests may be introduced. Among the pests which are common, and which the commission is preparing for by keeping up a constant search for their natural foes, are the following: Plant-lice, prune-aphis, woolly aphis, black peach-aphis, cabbage-louse, grapelouse, pear-scale, red scale, peach-root borer, peach - moth, canker - worm, tent-caterpillar, cherry-slug, Harlequin cabbage-bug, box elder plant-bug, Fuller's rose-beetle, various types of thrips, red spiders and mites of various 


\section{THE NEW EARTH}

kinds. It is believed that the foes of all these, as well as of all other dangerous pests, may be found.

The California commission does not advise the abandoning of the use of artificial protection wherever there is no foe at hand or wherever the foe does not as yet do its full service, but it points out that all these sprays, washes, fumigators and so on, are but makeshifts, that they are expensive, and that they cannot be relied upon to give permanent relief. Nature has somewhere a good bug to kill the bad bug; it is man's part to find the first and liberate him where he can destroy the second.

The attention of other states is being called to this remarkable work, with the probability of its indefinite expansion. There appears to be no reason why it may not be made to include practically all the insect pests. The national government has recently been at work along the same line, seeking to locate foes of the various pests affecting cereals, cotton and fruits.

The subjoined statement somewhat in detail of the damage of insect pests in the United States in a single year, prepared in the 



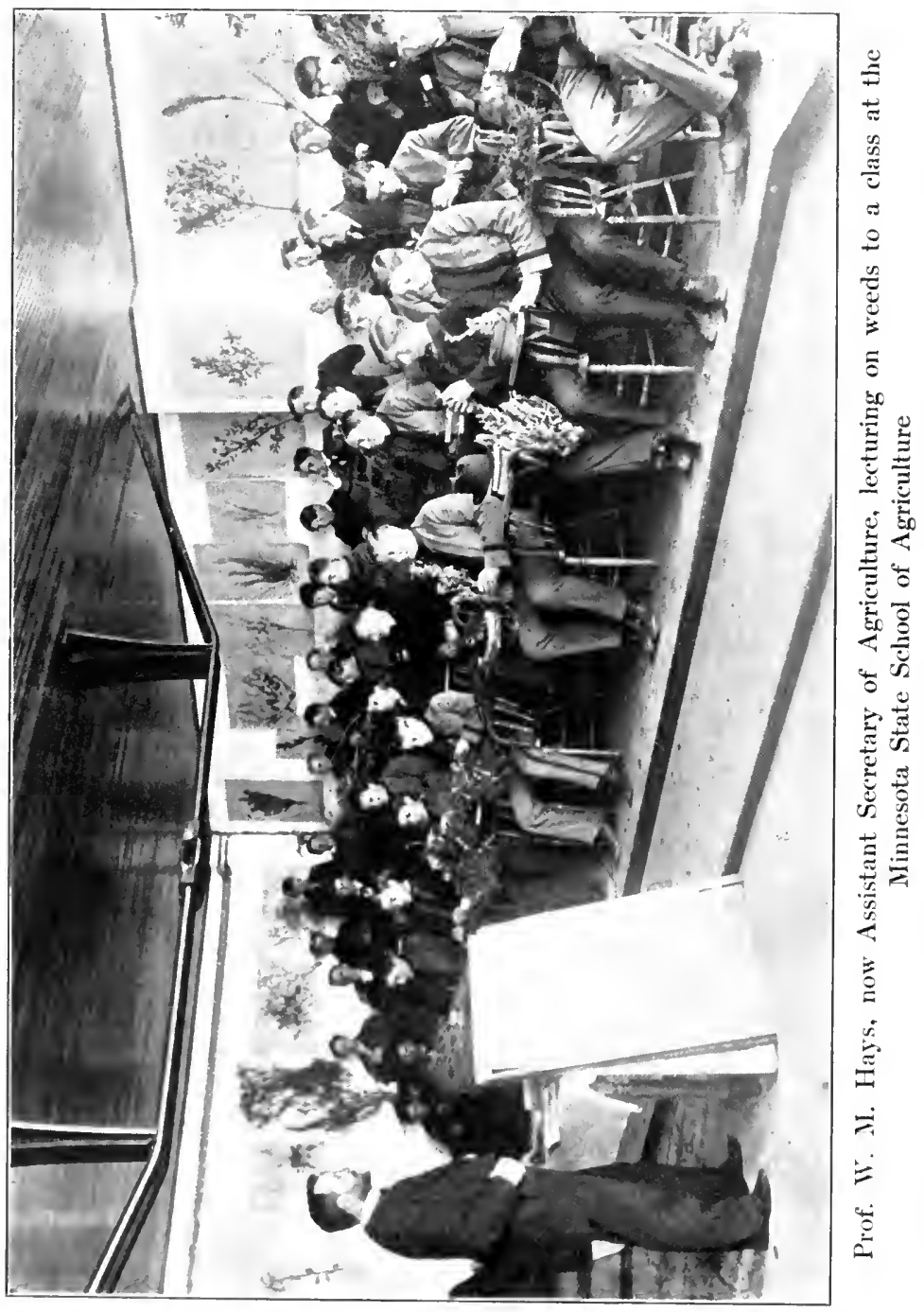




\section{THE ENEMIES OF PLANT LIFE}

Department of Agriculture in Washington, illustrates the need of some radical action. The California fruit-growers, driven to the last ditch and unable longer to cope with the pests by artificial means, appear to be able now to supply the remedy and prevent to a large extent this enormous annual national waste, which is apportioned by the government as follows: Cereals, $\$ 200,000,000$; hay, $\$ 53,000$,000 ; cotton, $\$ 60,000,000$; tobacco, $\$ 5,300,000$; truck crops, $\$ 53,000,000$; sugars, $\$ 5,000,000$; fruits, $\$ 27,000,000$; farm forests, $\$ 11,000,000$; miscellaneous crops, $\$ 5,800,000$; animal products, $\$ 175,000,000$; natural forests and forest products, $\$ 100,000,000$; a total direct damage by all insect pests per year in the United States of $\$ 795,100,000$.

'The annual value of the products in these

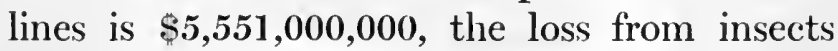
running from ten to fifty per cent. 'This does not take into account the indirect loss in the way of employees' wages, cost of attempted protection, injury to enterprises, and the like, in itself a large and growing sum.

It is one of the most significant steps in the progress of the New Earth, this destruction of 


\section{THE NEW EARTH}

one of the world's greatest foes by means provided by nature and carried out by man. A problem which has not only baffled the skill of the world since man first came upon it, but in whose solution fortunes have been sunk, appears now to have been solved, as many another problem has been solved, by the simplest of factors; - the remedy has been at hand all the centuries; it has only needed application. 


\section{CHAPTER VII}

THE WEEDS OF THE EARTH

TWHE affairs of the New Earth do not 1 always move smoothly. 'There are breaks and interruptions, obstacles are interposed; indeed, far and beyond these in injury are the robbers, persistently, systematically, ruthlessly stealing, and, when balked, not hesitating to press forward into cruelty. These robbers are reinforced in their activities, and re-supplied with strength, from the very sources out of which their victims derive their own life, and thus are doubly dangerous. It is quite as though the burglar who enters your house by night was also your son, living upon that which you have yourself accumulated.

Or it may be that to some the untoward situation which is presented suggests rather an organized internecine strife, a war between members of the same blood though differing in inclination and tastes. Looked at from this point of view, the strife is like that between 
national factions, the tide of battle now turning this way, now that, but a strife in which one or the other of the two must eventually conquer, there can be no compromise. Just as two practically independent nations with individual characteristics positively defined cannot forever live under the same flag, so these factors must stand apart. Once let them come into collision, extermination must be the portion of one or the other.

Or still differently looked at, this untoward situation in nature may suggest the survival of the fittest, - that age-long process depicted by the scientists in which the weaker is ever giving way to the stronger and the stronger ever giving place to the still stronger, and all slowly moving onward to a perfected whole.

But from whichever point of view you look, be it robbery or war or the survival of the fittest, the weeds of the earth constitute one of the most formidable agents ever established for man's overthrow. It is only as he conquers them that he rises. 'To whatever measure he yields to them, to that measure he is held in bondage. And, after all is said and done, man, in the physical sense, is but at best a weakling. 
He can kill other men, he can, in a measure, subdue nature, he can build up cities and tear them down. But in the presence of the tornado, when the sudden rush of the mighty locusts is in the air, when the lightning bolt falls, or the earthquake sends forth its tremors, or the hurricane sweeps his open boat in the sea, indeed, even with all his progress, when the great White Plague is at the door, he is powerless.

And when he lets Nature, in the amplitude of her vegetative powers, overtake him, he is well-nigh as helpless. The weeds of the earth, vagabonds that they sometimes seem, outlaws and outcasts, have a power not to be looked upon lightly. 'Their onslaughts are not matters of centuries or decades, but of seasons, even of months or weeks. By some sinister provision they are marvelously fecund. Under drought and neglect they thrive. When man ignores them, they rise to the height of their powers.

All sorts of definitions of weeds have come with their close study under the men of the New Earth. One scientist says a weed is : "Any useless or troublesome plant." Others say: 


\section{THE NEW EARTH}

"Every plant which grows in a field other than that of which the seed has been (intentionally) sown by the husbandman is a weed."

"Any plant which obtrusively occupies cultivated or dressed ground to the exclusion of some particular crop intended to be grown. 'Thus even the most useful plants may become weeds if they appear out of their proper place. The term is sometimes applied to any insignificant-looking or unprofitable plants which grow profusely in a state of nature; also to any noxious or useless plant."

"Weeds are plants which tend to take prevalent possession of soil used for man's purposes irrespective of his will and, in accordance with usage, we may restrict the term to herbs. Any herb whatever when successfully aggressive becomes a weed."

"A weed, so far as the farmer is concerned, is any plant whose growth interferes with that of the crops to which the soil is for the time being devoted. 'The idea of uselessness is always present in the mind when weeds are spoken of."

"Any unsightly or troublesome herbaceous plant that is at the same time useless, or com- 
paratively so, as a burdock or a dandelion: especially such a plant as is positively noxious or injurious to crops; also any herbacecus plant out of place, as a poppy in a wheat field or a stalk of wheat in a flower garden."

"Any one of those herbaceous plants which are useless and without special beauty, or especially which are positively troublesome. The application of this general term is somewhat relative. Handsome but pernicious plants, as the ox-eye daisy, the corn-flower, and the purple cow-wheat of Europe, are weeds to the agriculturist, flowers to the esthetic. So also plants that are cultivated for use or beauty, as grasses, hemp, carrot, parsnip, morning-glory, become weeds when they spring up where they are not wanted. The exotics of cold countries are sometimes weeds in the tropics."

"The general name of any plant that is useless or troublesome. The word, therefore, has no definite application to any particular plant or species of plants, but is applied generally to such plants as grow where they are not wanted and are either of no use to man or injurious to crops."

As man through the centuries has drawn 


\section{THE NEW EARTH}

distinctions between the tame and the wild plants, he has been ascribing all manner of curious characteristics to those which have been outside the pale of civilization. Certain peculiar qualities which the form or odor or size of the weed in some way suggested were applied by people with more or less vivid imaginations and have clung desperately to the weeds themselves. As the newer knowledge has advanced, the absurdity of many of the names, in so far as signifying any real quality is concerned, has become apparent. The manner by which these outcasts were given their names has in it such peculiar interest that a volume might be prepared upon them. The list of curiously named weeds is long-but a few of them will illustrate the point: Consumptive's-weed, otherwise known as bear'sweed, cancer-weed, asthma-weed, salt-rheumweed, Guinea-hen-weed, turpentine-weed, joyweed, rattlesnake-weed, soldier's-weed, bindweed, bishop's-weed, mermaid-weed, dyer'sweed, breast-weed, knot-weed, butter-weed, lake-weed, licorice-weed, carpet-weed, ragweed, trumpet-weed, mat-weed, mug-weed, neck-weed, ore-weed, morass-weed, tumble- 


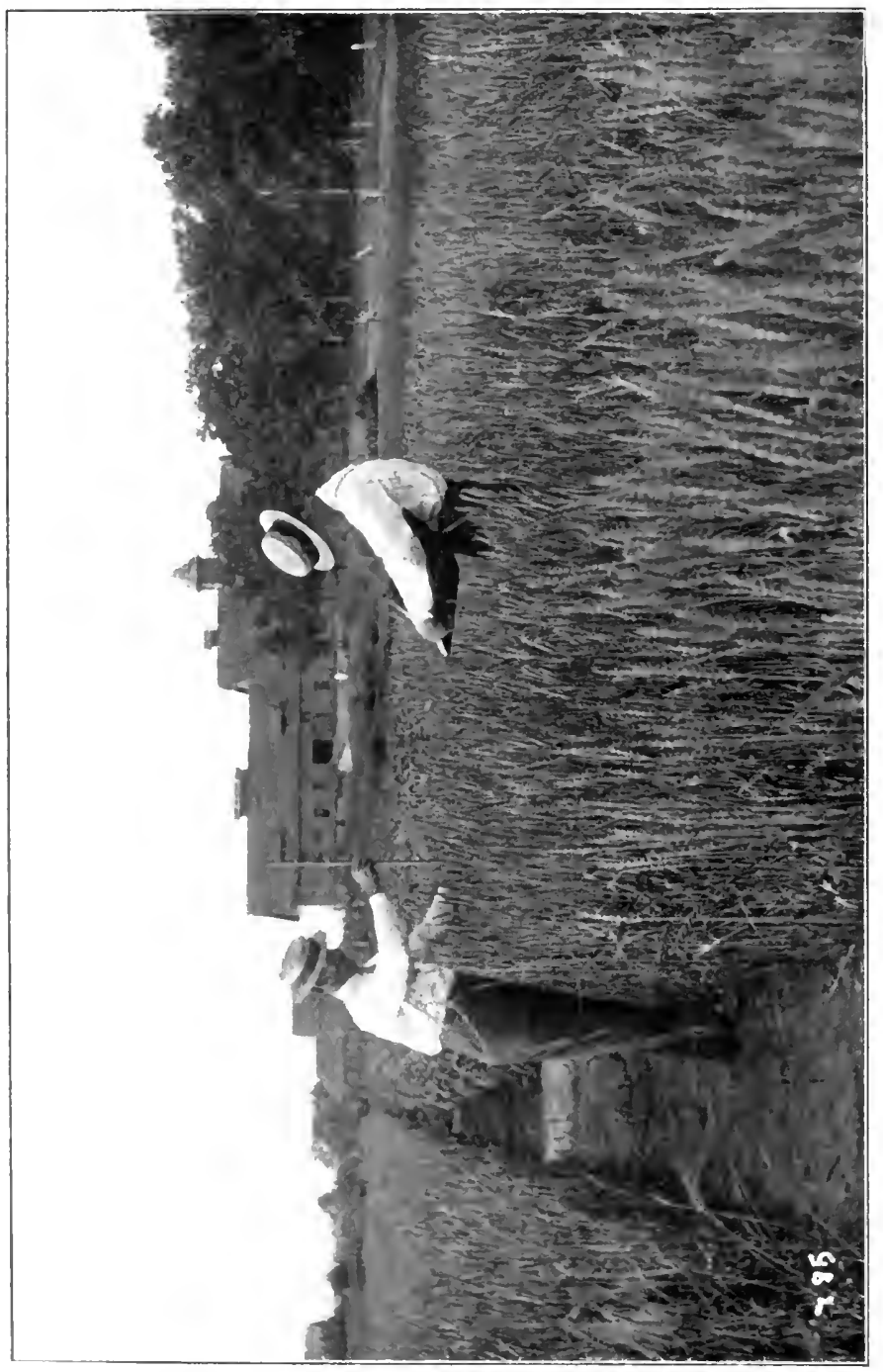

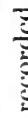

$\therefore$

$\Xi$

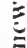

$\Xi$

5

完

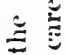

.

$\exists \equiv$

ت

છ

焉

i

$\stackrel{ت}{\underline{E}}$

茪

ㄱ

三

$\stackrel{3}{3}$

$\Xi$

丞 



\section{THE WEEDS OF THE EARTH}

weed, winter-weed, milk-weed, cross-weed, crazy-weed, emetic-weed, chicken-weed, cowweed, bird-weed, ague-weed,- - the list is indeed long and curious.

'The more one studies the character of these important factors in nature, the more one comes to comprehend their power. 'They not only compel man to make enormous sacrifice of time in cultivation and of money in the buying of implements to subdue them, but they stand ready, if he make one false neglectful step, to ruin him. They do not yield at a single attack, either, for beyond almost all other plants they have the qualities of hardiness and persistence. The part they have played, too, all unintentionally, in the development of man's own self-reliance is not small. As no gain worth the having ever comes without struggle, so no step forward on the part of man in his development of the earth can be made without meeting and vanquishing these bitter foes, thus adding measurably to his own strength. As the knowledge of the New Earth has broadened, men have learned that the weeds which were so often neglected in past years must have most serious and earnest 


\section{THE NEW EARTH}

attention. So, in the schools where agriculture is now taught, no closer attention is paid to any one subject than to that of the weeds of the earth. 'The students are taught how to tell the weeds on sight, all about their botanical construction, their life-history, how powerfully they work to take nutriment away from the soil. Weeds of every kind in the locality are brought to the class. Not only are they studied with as great care as the beneficent plants of the garden, the hothouse and the field, but the student must be able accurately to name and designate them merely by their seeds, branches or leaves. Given a handful of leaves, or branches, or seeds, scores of kinds among them, he must be able to construct from them the entire list of plants, much as a paleontologist reconstructs a pre-historic animal from a broken tooth embedded in the rocks for numberless ages. Much is learned, too, about the practical side of the question, based upon scientific exactness. 'The students are shown on due authority that the weeds in a given crop may easily reduce the yield of the crop by fifty per cent simply by taking from the soil the nutriment the crop is entitled to and 
absorbing the moisture which belongs by right to the crop. Not only do the weeds take up useful space, throw the crop into the shade and prevent the access of the sun, but the necessary heat is kept out and the requisite amount of air is withheld. When the weeds are analyzed they frequently show, as has been demonstrated by Prof. John Percival, of the Agricultural College of Wye, England, high percentages of potash and phosphates. Again, in spite of the utmost care, weeds are often harvested with the seeds of the crop proper, reducing largely the market value of the crop, and injuring, in the case of wheat, the quality of the flour made, unless the utmost care is exercised in cleaning before milling. The student learns of all this; of parasitic weeds that grow upon reputable plants and sap their life; that weeds harbor and give food to insect pests; that many weeds are poisonous to stock and that others not poisonous yet give disagreeable tastes and odors to the milk of the cattle who feed upon them. Nature is lavish in her gifts to the weeds. She gives the most of them marvelous fecundity, so that a single seed will produce as many as three hundred 


\section{THE NEW EARTH}

other seeds, and each of these three hundred, three hundred more apiece, the increase being at a rate too enormous for comprehension. A single seed may thus in three generationsprobably, under favoring conditions, less than a year to a generation-become the parent of twenty-seven million offspring.

And every one of these millions is of the robber brood, each one taking for his own worthless purposes that which should go to the enrichment of the earth. Some of the weeds are not only powerful in their attacks upon the storehouse of the soil by reason of the new plants constantly developing from the seeds, but they add to their robber equipment an underground system of attack. They send out stolons or rootlets, so to call them, which at intervals send roots downward and new plants upward, doing all far out of the sight of man. Others persistently send out runners above ground, which also at frequent intervals take root and form thrifty new plants. Various devices for the preservation and extension of their sway are put to use. Mechanical contrivances are common by which, when the time has come for the liberation of the ripe seed, it 
is thrown out with much force so that it and its fellows, flying at different angles, will cover the widest possible territory. Many are so prepared with wings or their substitutes that they are wafted hither or thither on the lightest breeze. Some bear a stout hook which, when the seed has been blown upon cattle or sheep, fastens the seed down into the hair or wool, to be loosened later by the animals as they rub them out of their long coats, thus scattering the weeds far and wide. There is something distinctly marauding in the sight of a long procession of the hateful Russian thistles bowling along across a fertile prairie in the autumn wind, scattering their evil selves over vast reaches of country and doing untold damage unless peremptorily challenged.

The student learns that there is only one word that applies to weed treatment if the farmer is to maintain his indcpendence,-extermination. 'The life-history of the weed must be studied,-its structure, its inclination, its habits, its peculiarities, its underground life fully as much as that above ground; but, above all, the best methods of extermination must be clearly learned in each individual case. The 
soil best adapted to their predatory wants must be considered, also, in order that the farmer may be forearmed for their destruction should they be reported on the way. Strange migrations of weeds are noted. It appears that they have stood most persistently in the way of glaciers, refusing to yield until crushed, and that as soon as the ice age passed and the warm zone rose, they persistently made their way back again to the place from which they had been driven. So they will migrate when cultivation has apparently exterminated them, leaving the haunts of man for more hospitable, wilder places. But once let man's vigilance cease to be eternal, back again they troop, a ragged, robbing horde, taking possession of the earth and converting the beautiful fields into wretched regions, fit only for the haunts of the wild.

'The weed is the clearest type of the savage. It may in time be tamed, it may become even highly civilized by the introduction of gentler blood into its veins, it may even be utilized to give tone and strength to an overdone and effeminate race of civilized plants, but it is essentially and forever savage if left to itself. 
And even if it come under the influence of civilization it will break away on the slightest provocation, and, if not held in check, will rapidly go back to its old wild, wandering ways.

I have always had a strong admiration for those powerful hordes who swept down across the face of Europe in the early centuries of the Christian era and threw themselves in all their savage fury upon the civilization of the great South. And one cannot but admire, in a certain contradictory sense, the tremendous power that nature has given to these vegetation savages as they sweep resistlessly across the earth, unless checked, and held in check, by the concerted efforts of succeeding civilizations. If but during this one generation of the New Earth, in which man in the mass has learned more about these enemies than he had ever known before, there should have been a universal abandonment of this concerted effort to keep down the weeds of the globe, the gaunt figure of Famine, arm in arm with Disease, and both overshadowed by Death, would today stalk unmolested across the earth, and man would rapidly approach the 


\section{THE NEW EARTH}

same extermination he now must wage against this tireless foe of the race.

While man through all the centuries, in a more or less successful way, has been combatting these enemies, and while, in America alone, he has spent hundreds of millions of dollars for fighting armament in the form of countless machines combining weed destruction with cultivation, he has yet been compelled to go further than this wholly individual effort and turn his attention to legislative action. Not all men who gain their living from the earth have taken note of the danger; few indeed, even of those who have studied most closely have ever come to any adequate comprehension of its magnitude, though, as knowledge has broadened, there have been many who have come to a realization of the imperative necessity of concerted action. So, to safeguard the many from the neglect of the few, laws have been enacted, stringently enforced, for the prevention and eradication of these foes. It would be of interest, did space permit, to show how widespread has been legislative action against weeds by the individual states during the last fifteen years. 



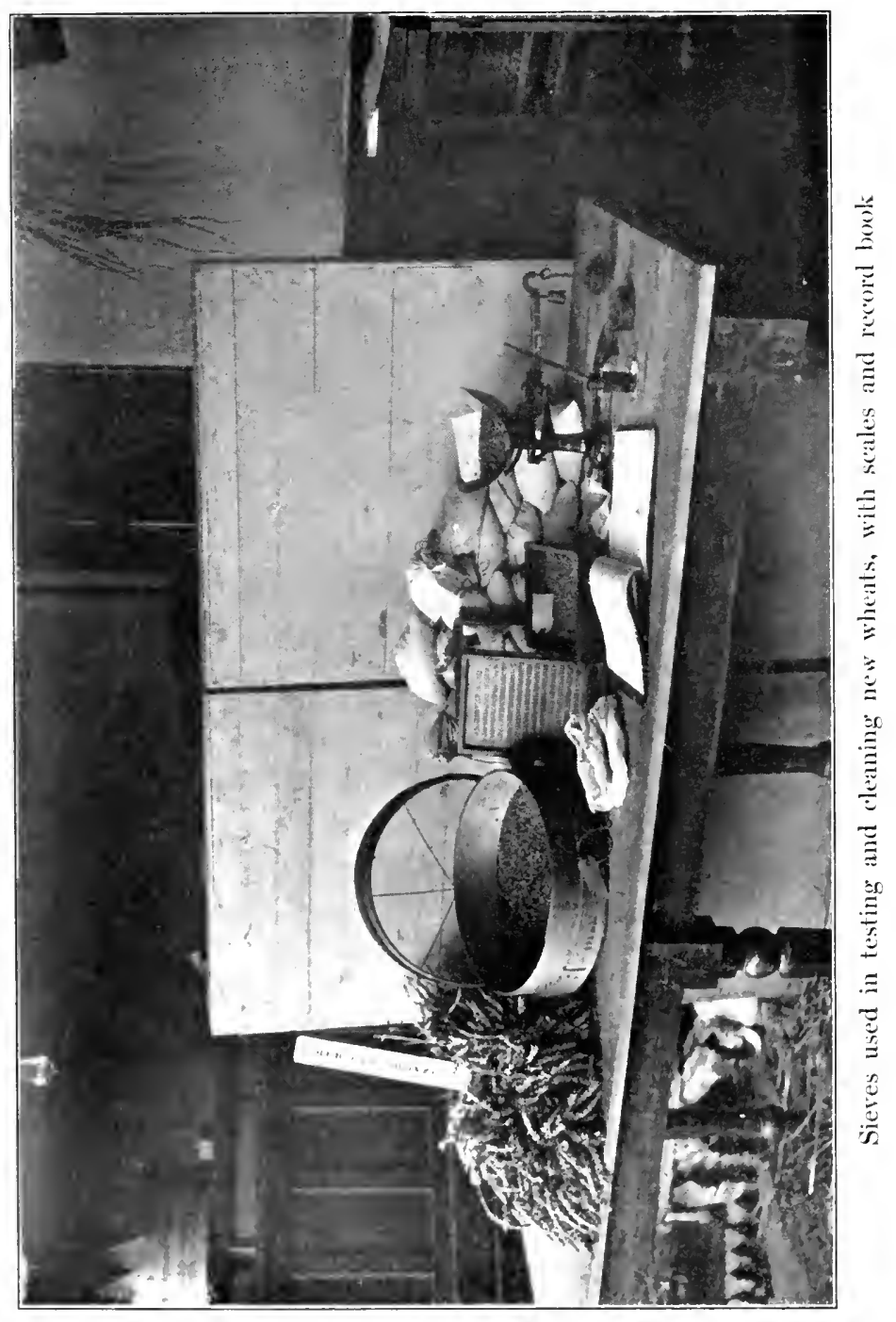




\section{CHAP'TER VIII}

\section{LUTHER BURBANK}

T $\mathrm{N}$ any consideration of the dominant forces 1 manifested in this regeneration of the earth, we may not overlook the powerful influence of the greatest of all plant-breeders, Luther Burbank. As the study of new conditions involves the earth and its products as well, we may turn briefly to the work of Mr. Burbank as particularly suggestive of great and novel events.

The New Earth abounds in surprises. It has apparently discarded its older prosaic self, partly because it has become so much more a source of happiness for man, partly because so many strange, and, indeed, spectacular, changes have been effected. It has been a rare alchemy which has been wrought in the alembic of the agriculturists, the transmuting of the lead of the commonplace and often the iron of the obnoxious into the gold of delight and the sterling silver of service. 


\section{THE NEW EARTH}

Perhaps more than any other man in the world has Mr. Burbank, though not an agriculturist, taken part in this transformation. $\mathrm{He}$ has worked with vital forces. He has gone out beyond those who have done strange things with electricity and chemicals into a realm where throbbing life abounds. He has dealt with life itself, seen and unseen; he has laid hold on this life, the marvelous life of nature, and molded it to his own patterns.

From him dates a new epoch in the plant development of the world. His greatest work ahead of him, he has yet accomplished more than any plant-breeder in the world in the way of the glorification and enrichment of the earth. This may easily be proven by a glance at his many lines of work, far too many for enumeration here, as they embrace over two thousand five hundred distinct productions brought forth in the midst of exhaustive experiments in every department of plant-life, and by their suggestiveness, especially in the amelioration of the race. He has been constructive from the very start, from the production of the potato which bears his name and which has been of such immense economic 
importance, his first creation, down through the long line that stretches across a third of a century and is still moving outward and upward,-always constructive. He has taken life and, while, apparently, removing something from it in order to reach his aims, has, in reality, only added to it, transforming it by constructive methods solely into a higher form of life than it had ever before possessed. And it is a higher form, too, than unaided nature ever could have attained. Mr. Burbank stands as the most conspicuous aid to Nature in improving plant products for the race, the leader in massing and commanding her forces in this direction; should it so be that others shall arise to carry forward his great work when he shall have laid it down, his influence will be still more difficult to measure in words.

His life-work may be included under a dual aim, so to call it, embracing, first, the recreating or regenerating of old forms of plant-life, wild, neglected or degenerate and the improving of those by many considered satisfactory but in which he sees room for important additions; and, second, the creation of entirely 
new forms of life, to supplant inefficient ones or to stand apart as unique additions to the vegetable kingdom. He has primarily accomplished his work by a series of systematic experiments covering, in each instance, periods of many years; though this is but the outward manifestation of his activities. It speaks nothing of the intense application, the wonderful inventive powers by which he is enabled to make selection of the one best of, say, a hundred thousand plants, the patience, the scientific searching for new truths, the consummate art in the blending of life forces never before united.

Mr. Burbank's life is many-sided, its facets surpassingly brilliant. It is the diamond of a supreme unselfishness. We may throw light from but two of these facets for present purposes, bringing forth, first, that he has never wasted any time in the production of a fruit or a flower merely for the sake of having it said that he had done some unusual thing; and, second, that he has accomplished all he has done by dint of the utmost labor, wearying, many times to the very last degree, often, in his earlier years, in the stress of privation 
and want, with the ultimate end always in view of producing that which should help the world.

In furtherance of this latter, he has sold his new creations with the distinct understanding that there were no restrictions upon them, so that the general public could secure them at the earliest moment, while the money he has received he has devoted to the carrying forward of other tests.

He has had always before him, in the creation of a new fruit, its adaptability to the needs of man, never seeking to make greater varieties of fruits for the mere purpose of showing that it could be done, but having a definite, practical aim before him,- the new fruit must be better than the old, better in point of food, beauty, yield, shipping qualities, adaptable to a wider zone of culture than those that had preceded it.

His ends have been accomplished along the general lines of breeding and selection, crossing two plants to produce a better than either, and then, through a long series of years, steadily selecting the very best of their progeny until, at last, he gets a plant that reaches 


\section{THE NEW EARTH}

the ideal he had set for it from the beginning. Oftentimes strange new traits have developed, and these have been carefully fostered if they seemed to lead to something better; but if they merely seemed to promise something spectacular, they have at once been consigned to the fire. So he has gone forward, making improved flowers, fruits, grasses, nuts, trees and vegetables,-indeed, more than this, creating wholly new ones by combinations hitherto believed impossible. Where he can guide the forces of Nature for the benefit of man, he does so; where he can lead her beyond her usual manifestations, he does so with the utmost reverence for her. If he sees that two widely separated plants may be united to produce a third far better than either, he does not hesitate to do that which Nature unaided could never accomplish in a thousand years,- - he joins them in the most intimate union, merging one life for all time into the other.

In accomplishing all that he has achieved, he has worked along two main lines,- the scitific and the practical,--never losing sight of either. He is the most practical of men in making a new plant or recreating an old one; 
but he is preëminently the man of science, at the same time, continually adding to the total of human knowledge, continually exploring regions before unmapped. He has worked with a million plants if needs be in a single test, so that he has had incomparable opportunities for observation. It was in recognition of this dual character of his work, and of the enormous possibilities stretching out before it in each line, that the Carnegie Institution of Washington offered him a grant of one hundred thousand dollars for the ten-year period beginning with 1905. By means of this grant Mr. Burbank will be enabled to carry on his work on a very much larger scale, both as to its practical character and in the interests of science. The subvention came to him unasked - it was accepted as it was offered in the spirit of service to man.

Among the most important of Mr. Burbank's creations, from the point of view of the New Earth, are a new series of hybrid thornless, edible cacti, by means of which the desert places of the earth are to be reclaimed; the new fast-growing trees which will aid in rapidly re-foresting denuded areas; the long 


\section{THE NEW EARTH}

list of improved fruits; the creation of the primus berry, the phenomenal berry, and the plumcot, absolutely new species produced by the hand of man; new and improved varieties of vegetables; grasses for lawn and forage superior to the old and far more hardy and prolific; new and vastly improved strains of flowers, more beautiful, hardier, larger, in every way enhanced;--these but hint at the creations from his hand, while others promising still more for the world are under way.

World-wide attention has been attracted to the man and his work. Newspaper and magazine comment and descriptions have been widespread in this and foreign countries. He has been given recognition such as few men in private or public life ever receive. But the only result of this universal praise has been to strengthen the determination to do yet more for the world. Mr. Burbank is never unmindful of appreciation, just as he is never in any sense influenced by mere flattery. 'The recognition has come from people in all ranks of life, from the very poor and the very rich, from the daylaborer and from crowned heads in Europe, from scientific men and practical men of 


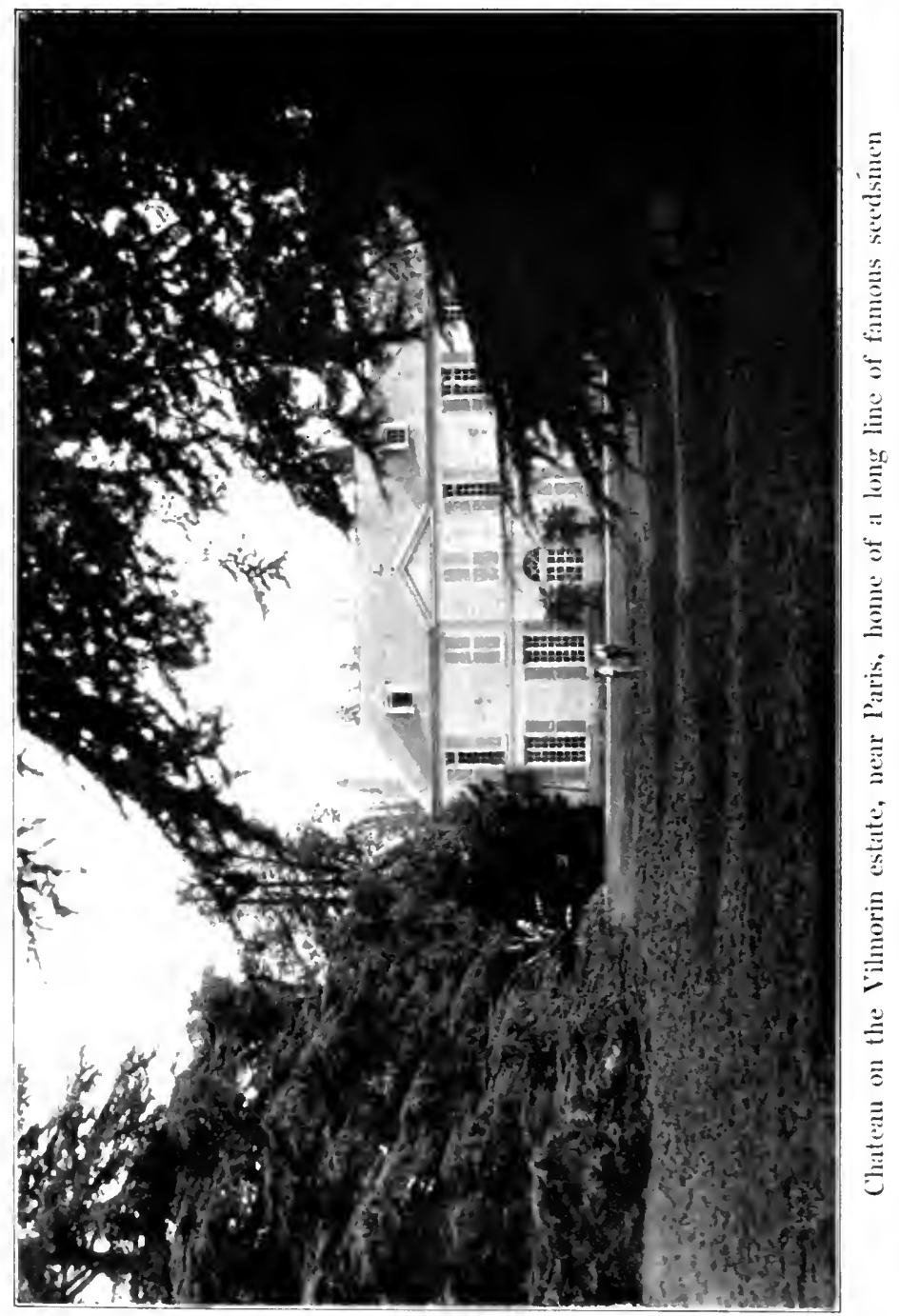



affairs, from learned societies and from institutions of learning.

Thousands of visitors have made the pilgrimage to his home in Santa Rosa, California, every year. The most determined effort has been made on Mr. Burbank's part to lessen the number of these visitors, not because he has anything secret in his work, for it is all as open as the day, not because he holds himself aloof from people, for no man takes a livelier interest in men and affairs; but because his work demands that he be left alone. His grounds at Santa Rosa and Sebastopol, his larger proving place some eight miles from Santa Rosa, are absolutely private. No person has any right to disregard the plainly written signs which have been posted at his gates. Not only do visitors consume much of his time, thus wearing heavily upon his strength, but they interrupt him in the midst of experiments which demand constant supervision. Thus the loss is two-fold, to the man in energy wasted, to the world in new achievements.

Very much of beginning work in the tests commences at Santa Rosa. Here, on the grounds where Mr. Burbank has his home, are 


\section{THE NEW EARTH}

several acres devoted to preliminary tests and, in the case of many flowers, to final tests. At Sebastopol are some seventeen acres of ground where events move on a larger though not more interesting scale. Here hundreds of thousands of fruit trees, vines, shrubs and plants of all descriptions are under test at the same time. In all cases, the chief factors in the work are breeding and selection, and here selection assumes its most important feature; for often the best plant must be chosen by Mr. Burbank out of ten thousand,--indeed, out of a hundred thousand, it may be.

When the new plant has been grown for a sufficient number of generations, so that it will not go backward to some former inferior condition, it is ready for the world. It has received the final test, it has passed the last examination, it is a full-fledged graduate with this exception that, instead of beginning life and learning the ways of the world, it has been completely fitted for its service during the years it has been in training. In order to accomplish all that he has done, Mr. Burbank has drawn heavily upon his physical resources; sometimes, indeed, he has made an overdraft 
that has caused him annoyance; but so absolutely temperate is his life that he has always been able to recuperate when the long strain of some protracted test has ended. He has infinite patience, the rarest intuition, never yielding to discouragements, never led into torpor by the splendid series of triumphs that have attended his course.

The New Earth of today is his debtor beyond words; tomorrow his service shall be of far greater significance, for in all that Mr. Burbank does it is the future that reaps greatest. It has been many years since he created the potato, for instance, which bears his name, and it has been steadily adding millions of dollars to the national wealth. So, with many of his creations, their development comes with the years. It is only about twelve years since, in 1893, he gave up a large and lucrative nursery business in order to devote his entire time to the production of new creations, and to educate the world, so to speak, to its possibilities in this line, and very many of his productions,- - so long the time required to fit a fruit or a flower or a vegetable for the world,- are barely coming into use. 'There are no measure- 


\section{THE NEW EARTH}

ments alongside of which to determine the value of his creations. It is not more difficult to tell how much he has added and will add to the world as his fruits progress, from a commercial and practical point of view, than to tell how much he has added to the world's store of beauty and delight.

Great as have been his achievements, both as a man of the practical and as a man of science, enormous as must be the sum of his benefits to the world, they are still less than that which shines out of his life with a steady, splendid glow in the midst of this day of crass indifference on the part of many to the rights of others - the light of an absolute unselfishness. It is not a light which is, after all, though powerful, of chief value to show the way to him; it is, rather, the one which goes out in every direction wherever he has sent a plant or a seed, forever making new centers of light for others. The world has much to learn of Luther Burbank along the path of knowledge and in the realm of science: it has more to learn from the example of the man himself. 


\section{CHAPTER IX}

\section{HORTICULTURAL PROGRESS}

THE twelfth census of the United States,

1 of the year 1900, was the first one in the history of the country in which an effort was made to obtain definite reports of the value of fruits grown in the United States. During nearly two centuries and a-half fruit-growing had been largely a matter of the individual, never commanding enough, in a commercial way, to warrant national recognition.

The development of the fruit industry, however, in the period of which this book treats, had been so rapid that the government took large pains in this census properly to show the extent and importance of this new factor in national life. Fruits had been grown from the beginning. Indeed, in that far day when Norse Lief, son of Eric, made his memorable voyage to the new world, in the year 1000, it was the abundance of grapes which he found growing wild that caused him to name the region Vine- 


\section{THE NEW EARTH}

land. In 1562, came oranges, planted by the Spaniards where now stands St. Augustine, Florida, and about the same time the Jesuit fathers, in the Great Lakes region, introduced the pear. The first vineyard came in 1610, planted by Lord Delaware, in Maryland, though the native grapes that were found by some of the early explorers in the Virginia region were pronounced fully equal to the best European grapes. The colonists, in New England, found many wild berries and grapes that delighted their hearts. One, William Wood, is quoted as reporting back to England in 1629:

"There is likewise Strawberries in abundance, verie large ones, some being two inches about; one may gather halfe a bushell in a forenoone. In other seasons there be Gooseberries, Bilberries, Resberries, Treacleberries, Hurtleberries, Currants, which, being dried in the Sunne, are little inferior to those that our Grocers sell in England. The Cherrie trees yield great store of Cherries, which grow on clusters like grapes; they be much smaller than our English cherry, nothing near so good if they be not fully ripe; they so furre the mouth that the tongue will cleave to the roofe 


\section{HORTICULTURAL PROGRESS}

and the throat wax hoarse with swallowing those red Bullies (as I may call them), being little better in taste. English ordering may bring them to be an English Cherry, but yet they are as wilde as Indians. The Plummes of the Countrey be better for Plumbs than the Cherries be for Cherries; they be black and yellow, about the bignesse of a Damson, of a reasonable good taste. The white thorne affords hawes as big as an English Cherrie, which is esteemed above a Cherrie for his goodness and pleasantnesse to the taste. Vines afford great store of grapes, which are very bigge both for the grape and Cluster, sweet and good; These be of two sorts, red and white, there is likewise a smaller kinde of grape which groweth in the Islands, which is sooner ripe and more delectable; so that there is no knowne reason why as good wine may not be made in these parts as in Burdenaux, in France, being under the same degree."

John Smith wrote concerning some of the fruit which he found in the new land:

"Plumbs there be of three sorts. The red and white are like our hedge plumbs; but the other which they call Putchamius, grow as 


\section{THE NEW EARTH}

high as Palmeta. The fruit is like a medler; it is first green, then yellow, and red when it is ripe; if it be not ripe it will draw a man's mouth awrie with much torment; but when it is ripe it is as delicious as an apricot."

A pear tree in New York city, planted as early as 1614 was still standing at the corner of Third avenue and Thirteenth street in 1866, and perhaps would have been to this day, nearly three centuries later, if it had not been broken down by a passing dray. Apples came before 1639, for in that year the records show that five hundred barrels of cider were made in New York. It was not until many years later, at least two centuries, that the apple developed to any great extent into a fruit to be eaten out of hand; it was for all the earlier years a cider-producer chiefly.

When the early Roman Catholic priests made their memorable journey up from Mexico through the region of Spanish territory now California, along in the earlier and middle part of the eighteenth century, they brought with them the olive, the pear and the grape, and found a most hospitable home for them. But it was not until the New Earth's period 



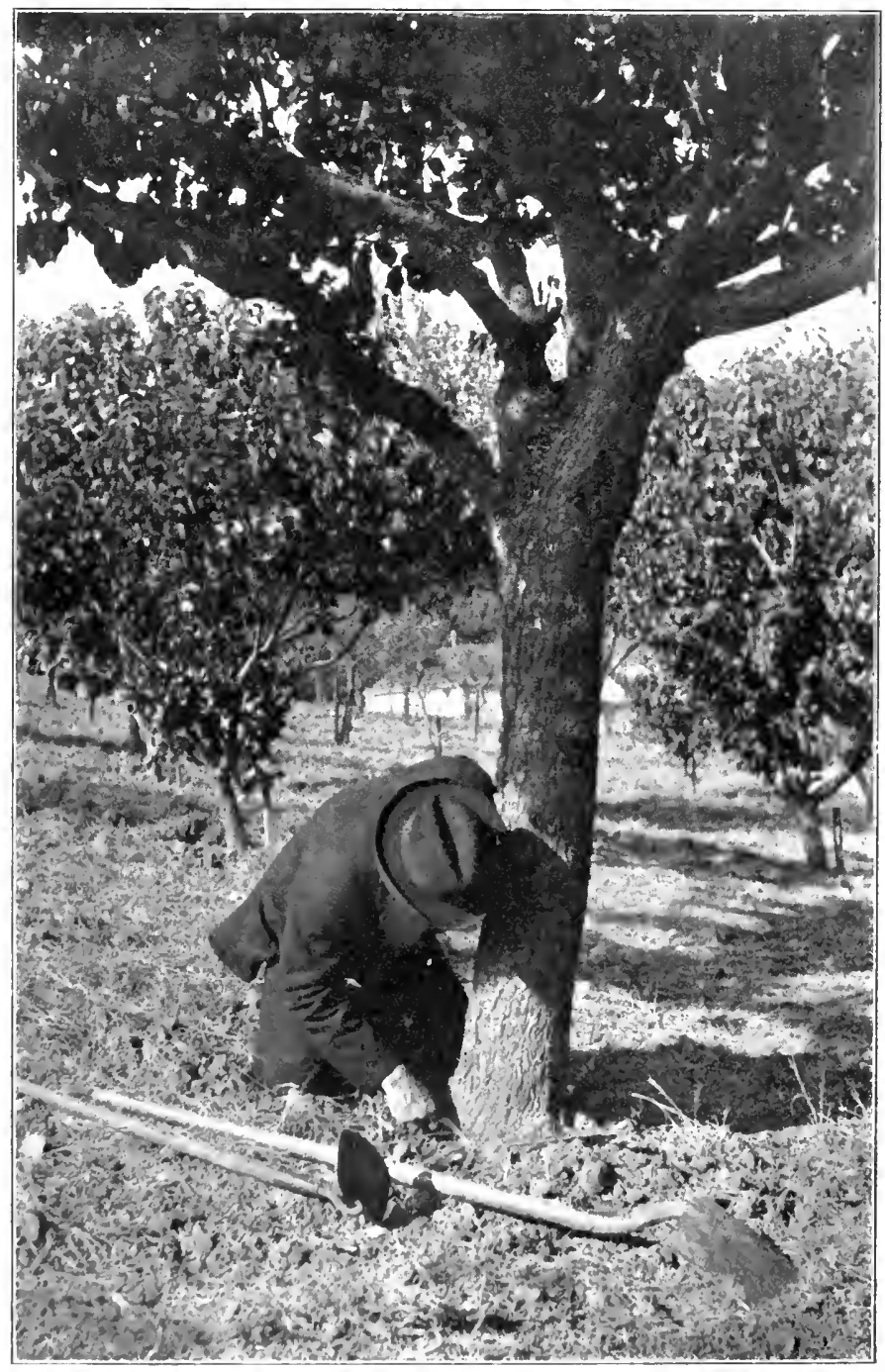

Siearehime for the peach root-borer 
that horticulture began to emerge from individual control into state and national prominence. I uring this period the growth has been so rapid that there are, in 1906, more than three hundred and seventy-five million fruit trees growing in America, an increase in the ten-year period 1890-1900 of nearly two million trees, while, in the same period, the output of fruit increased 1,500,000,000 pounds,-a suggestion of the impetus of the new industry under new conditions.

It was not until 1886 that prune-grafting began, the first grafting being in San .José, California, in the Santa Clara Valley, now the richest prune region in the world. Since that date, in California alone the prune crop is from $150,000,000$ to $190,000,000$ pounds, while large quantities are now raised in the adjoining states of Oregon and Washington. It is of interest to note in this relation that the importation of foreign prunes fell away from nearly $\mathbf{3 5 , 0 0 0 , 0 0 0}$ pounds in 1897 to less than 500,000 pounds in 1904, owing to home production, and a very large proportion of this latter amount, it is said, was first sent abroad from California, treated over again in France, "pro- 


\section{THE NEW EARTH}

cessed" as it is called, repacked, and sent back to the United States as imported French prunes. Some hint of the recent remarkable development in other lines is seen in the fact that, according to the last census, the apple trees of the United States in the ten-year period, 1890-1900, increased in number more than eighty million. Eleven years ago, in 1894, California sent out a little over five thousand car-loads of oranges, something like a million six hundred thousand boxes. The shipment now is about thirty thousand cars a year, over ten million boxes. Raisins, lemons, olives, dried fruits, canned fruits in this, the largest fruit-producing state in the Union, have also remarkably increased in production.

But one of the most interesting of all the horticultural developments of the period of the New Earth has been the production of figs. Figs of an inferior quality had long been grown in the United States. Even in colonial days the fig was introduced, but none of the figs of this or later periods could compete with the Smyrna fig. 'The reason for this lay in the powerful influence of a wasp. In the region round about Smyrna, in Asia Minor, the fig is 
abundant. Alongside the rich fig trees, or in close proximity, are other trees, caprifig trees, so called, which are the resort of a wasp whose chief duty in life is to lay its eggs where they will hatch out upon the early fruit and blossom of the caprifig. Laden with pollen from the caprifig, the young wasps seek other fig trees to lay their eggs, and as there are edible figs in abundance in the region, they deposit the fructifying pollen they have collected upon the edible figs and, as a result, seeds develop in abundance, the figs are greatly enriched and take on a most delightful taste. Without the aid of the wasp, even the edible figs would be of little value. This led long ago in Smyrna to caprification, which consists in suspending a branch of the profichi, or first-crop figs of the caprifig, upon the branches of the edible fig. 'The wasps hatch out on the caprifig, seek other figs, find the edible ones at hand,- the caprifig trees in this instance being grown some distance from the edible ones, - and the result is that the pollination is complete, the wasp has done its work, commerce has been' aided, man has been given a toothsome and healthful food. The wasp has been given a name of formidable 


\section{THE NEW EARTH}

proportion, Blastophaga grossarum, but it goes on about its appointed mission just as nimbly as though it had no such burden to bear.

Under the stimulus of all the activity of the New Earth, which apparently pervades all modern effort, the fig was not left to its miserable estate in the country of its adoption. Everything in the New World was in its favor, climate, soil, demand. So the fig-wasp was induced to come to this country, the edible figs were pollinated, and the same transformation that has all the centuries annually taken place in the home of the fig, in distant Asia Minor, now is wrought in America. While in 1891 the cured fig output of California, where very largely the fig is grown, was only three hundred and sixty thousand pounds, it has now increased to from five to seven millions of pounds per year, and the character of the product is pronounced superior to the Oriental fig both by analysis and by the test of expert opinion, while the domestic fig is far more desirable from the important standpoint of cleanliness.

Before considering the question of horticulture in smaller lines, it may be of interest to note as a suggestion of the really wonderful 
growth of the fruit industry of recent years, that while California leads in fruit production, the value of the product by the last census, being $\$ 28,280,104$, or 21.5 per cent of the whole, New York produced in the same year fruit to the amount of $\$ 15,844,346$; Pennsylvania, $\$ 9,884,809$; Ohio, $\$ 8,901,220$; Michigan, $\$ 5,859,362$, these five states producing 52.3 per cent of all fruit raised in the United States. In the decennial period referred to above, 1890-1900, the greatest relative increase was in plums, 334 per cent; pears following at 246 per cent; apples, 68 per cent.

Along with this rapid development of commercial horticulture has come a marked revival of and expansion of interest in intensive horticulture. Here lies marked opportunity for the man who raises fruits partly because he wishes them fresh for his own table, but more because he has fallen in love with the occupation itself. The revival of interest in outdoor life in the past generation in America has no doubt had an important bearing or individual fruit-growing on a small scale. It not only provides means for considerable increase in revenue through direct sales and, indirectly, through 
supplying the home table, but it affords opportunity for most fascinating experiences, vastly increases knowledge and love of nature, and, at the same time, is of marked value as an aid to health. It is quite remarkable, too, when one comes to consider it, how much may be accomplished in fruit-raising in close quarters. One may see something of this in the remarkable cleverness of the French orchardists in the training of pear trees to grow flat upon walls or trellises, thus materially economizing space. In the cramped back yard of a city house in San Francisco a lover of fruits has over seventy different varieties of pears, peaches, grapes, quinces and cherries growing in rich profusion and yielding abundantly of luscious fruit.

Mr. L. C. Corbett, horticulturist of the Bureau of Plant Industry in Washington, in a contribution to the Year Book of the Department of Agriculture lays out a plan for an orchard in a space of ground sixty by eighty feet in size. 'This comparatively small space will accommodate four hundred and seventytwo fruit bearing plants, arranged as follows: 'Thirty-two grape-vines dispersed at intervals 
of ten feet around the entire garden; three rows each containing six dwarf pear trees, eighteen specimens in all; six species each of peaches, dwarf apples, cherries and plums; twenty blackberry specimens; forty blackcaps; forty red raspberries; three hundred strawberries.

Not only is there opportunity even in cramped quarters for the successful growing of fruits, but there is also a still more interesting and, possibly, profitable allied line, the breeding of new fruits by cross-fertilization and selection. Whoever is able to produce a new type of fruit or so to enhance the value of an old one that it will supplant existing ones, not only performs an act of surpassing interest to himself and friends, not only derives a snug sum from the sale of the new fruit, if he so desires, for wider introduction by some noted nurseryman, but adds markedly to the pleasure and the welfare of the race. It may be, indeed, that large wealth may accrue to the nation and the world through this addition to its food forces. Marked impetus has been given to this in recent days through the fascinating work of the great plant-breeder, Luther Burbank, who, using such methods and such 
implements as are ready at the hand of any one interested, has not only added enormously to the wealth of nations but opened the way to an indefinite expansion of his work on the part of others. Fruit-breeding offers to the amateur horticulturist opportunities rich in possibilities.

But not only has modern horticulture, the horticulture of the New Earth in America particularly, shown rapid development in the way of increased tree and vine planting, and not only has individual interest heightened, both in production and in the breeding of new types, but the fruit-growers of the United States have steadily looked beyond the borders of their own country in their search for a market for their canned and dried goods, and, in lesser measure, due to the time consumed in long shipments, markets for fresh fruit. In 1870 the export of fruits "preserved in cans or otherwise" from the United States to foreign countries amounted in value to $\$ 81,735$. Slowly, as the increase in the area of fruit grown in the country enlarged in this generation, the export trade has increased. 'Ten years later, in 1880, the value of export 


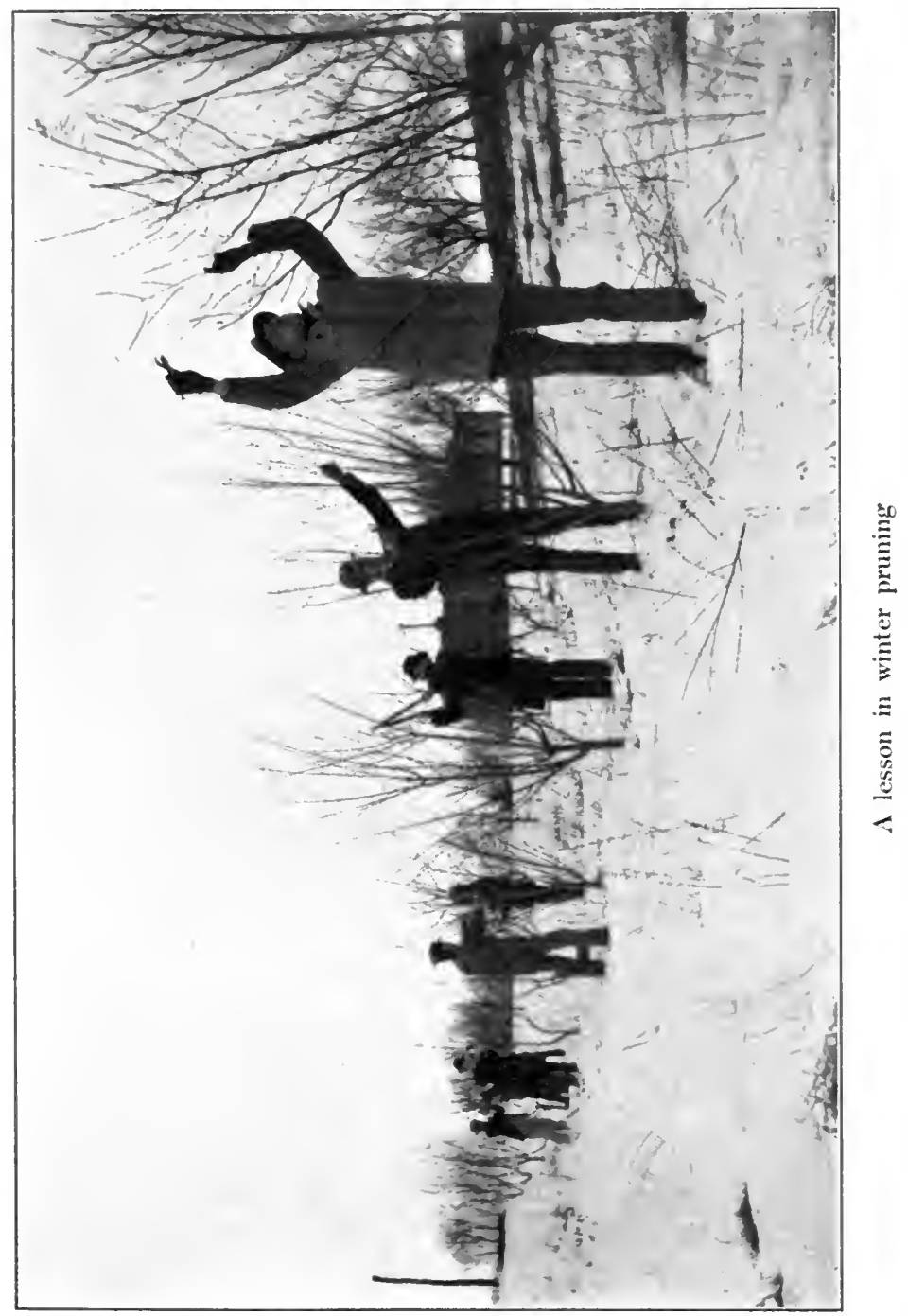



canned fruits had advanced to $\$ 371,118.50$. Ten years more, and it was over six hundred thousand dollars. In the next decade the foreign trade in fruits increased in a still more significant manner, and in 1904 we exported to the amount of $\$ 2,677,002$. The increase in the export of canned fruits and vegetables in the decade from 1890 to 1900 was 350.4 per cent. The dried fruit industry during the period of the New Earth has had remarkable growth. In 1895, when fruit-drying for home and foreign markets was becoming popular, we exported about fourteen millions of pounds of prunes, but in 1904 over seventy-three millions of pounds. Almost sixteen millions of pounds of raisins were imported in 1895 as against $6,800,000$ pounds in 1904, while, along with this import raisin trade under the impetus that has been given to American raisin production, has developed an export trade in raisins amounting now to nearly three hundred thousand dollars annually. The amount of the dried apples exported from the United States in 1895 was a trifle over seven million pounds; in 1904 it was nearly fifty million pounds. A generation ago, in 1870 , the total value of all 


\section{THE NEW EARTH}

fruits and nuts exported was about five hundred thousand dollars, while, in 1904, this had risen to over twenty million, five hundred thousand dollars.

In 1870 we produced fruits to the value of $\$ 5,425,677$; in 1880 , it had increased to $\$ 17$,549,576 ; in $1890, \$ 29,862,416$; in 1900 , $\$ 56$,668,313 , while the increase during the present decade promises to be even larger. There were only ninety-seven establishments for canning and preserving fruits in the United States in 1870, while in 1905 there were over two thousand.

These figures will suggest the advancement in fruit culture during this period from a commercial point of view. It is quite as significant an advance as that shown in individual interest in this most delightful occupation. With a steadily increasing demand, home and foreign, and with a steady widening of the zone of culture, the fruit industry, large as has been its progress during the generation, appears but at its real beginning. 


\section{CHAPTER $\mathrm{X}$}

MODERN FORESTRY

TWO things stand out with peculiar clearness in the recollections of a long journey from the island of Gotland in the lower Baltic, a thousand miles or more to the north, beyond the arctic circle, in Sweden,-one of them the use of the elm trees in the country places of the quaint island to the south, as a source of food supply for the cattle, by trimming the trees of their young leaves and sprouts, in the early summer, to be stored away for winter feeding for the sheep and cattle. The other was the great stretches of pine through which we passed on the day ride by the government railroad north from Stockholm, where the road winds in and out among the mountains through a most picturesque region, the Switzerland of northern Europe. Very much of the pine of the Swedish forests has been preserved simply by means of the same sort of pressure that is now brought to 
bear in the United States. The forests, largely owned by stock companies and individuals, were rapidly going the way of destruction, despite the centuries of testimony on the part of Germany, to the south, that it pays to preserve the forests and harvest them, and the work of preservation and protection was begun by the government just in time. Sweden now has her national school of forestry, and is abreast with modern progress in preserving and extending her forests.

While much has been done within a generation, in our own country, by way of education, to show those most immediately concerned, the lumbermen, and those most vitally concerned, the people, that it pays to keep faith with Nature in her forests no less than in her soils and their products, yet much remains to be done. We shall find, however, that it is only since these years of the awakening of the New Earth that real practical, telling work has been done. In the generation of the New Earth's most rapid growth, forestry in America has been born, or, a better figure, has been galvanized into life. Sporadic, though most earnest attempts were made, all through 
the earlier and middle portion of the century just closed, to arouse interest in forest preservation, but it was not until 1876 that anything like effective national steps were taken, and not until 1881 that the present Bureau of Forestry was established. The work of this Bureau became greatly widened and enhanced in importance through the transference, in 1905, of the management of the forest reserves from the land office of the Department of the Interior to the Forest Service,-a sensible and logical act. In 1898, Mr. Gifford Pinchot was appointed forester, an admirable selection. 'To him great credit is due for the progress of American forestry.

Sixty-three millions, three hundred thousand acres of forest thus came under the care of the Bureau of Forestry, and upon this large, but still all too inadequate tract, practical problems of forestry are being solved upon a large scale. How to conserve these forests; how to harvest out the merchantable timber and provide for regular karvests through coming decades and centuries; how to help those who need forestry service to the best possible advantage, so that their timber-lands may be continuously 
productive; how best to train that increasingly large number of young men who are leaving college life for the calling,--indeed, one might almost say, the profession, of forestry; how to do all the detail work of valuation, forest measurement, record-making, and the like; how to create forests where none now exist,- these and many another question are coming up in these days of the New Earth for settlement. Under the wise administration of affairs, these questions are being settled for the practical good of the present and the future as well; for, after all, the forester is largely the man of tomorrow. Today in forestry is important; tomorrow is all-important.

Before this service stretches unlimited opportunity in the one particular of reforesting the denuded areas. I recall a ride one late winter day through a great pine forest in a northwestern state where, as yet, no axe had struck a blow. It was a magnificent primeval forest, with splendid opportunities for harvesting the trees that were large enough for the mills, and for nourishing the younger pines that were coming up in the open swales and crowding even their nobler brethren in the 
depths of the forest itself. There was need of the axe and saw, for the forest had long been ripe for the harvest. Indeed, it was plain that the trees now growing would have been much larger, and in all ways better, if in some past day approved forestry methods had been in vogue.

A few years later I had occasion to pass through the same region. The whole wretched tale of greed and wastage lay before me. Where the noble forest had stood was only a long reach of barren land, swept by fires-a blackened dismal waste of death. The land was absolutely non-agricultural. It was unfitted for agriculture, both by climate and soil, it was preëminently and absolutely forest land alone. Not a tree had been left standing. Even the little ones, barely more than saplings, had been cut away in the ravenous desire to strip the earth. Not the slightest effort had been made to reforest the region, much less to leave standing the unmerchantable timber. All the conditions most admirably favored the continuance of the forest, and, if ordinary common sense and an ordinary regard for the future had been consulted, the forest would have 
been good for a thousand years. It was a most pitiable exhibition of greed: more than that, it was a distressing commentary on the business sense of the men who stripped it; for the region could have been made a source of perpetual profit instead of an utter loss, by simply following the lead of ordinary common sense.

At a meeting of the American Forest Congress which convened in the city of Washington in January, 1905, President Roosevelt, in addressing the congress, spoke these words, at an earlier date, before the beginnings of the generation of the New Earth, they would have been fit words for laughter or ill-concealed anger on the part of the men who in that day were ravaging the forests:

"You have made, by your coming to this congress, a meeting which is without parallel in the history of forestry. For the first time the great business and the forest interest of the nation have joined together, through delegates altogether worthy of the organizations they represent, to consider their individual and their common interests in the forest. . . . You all know, and especially those of you from the 



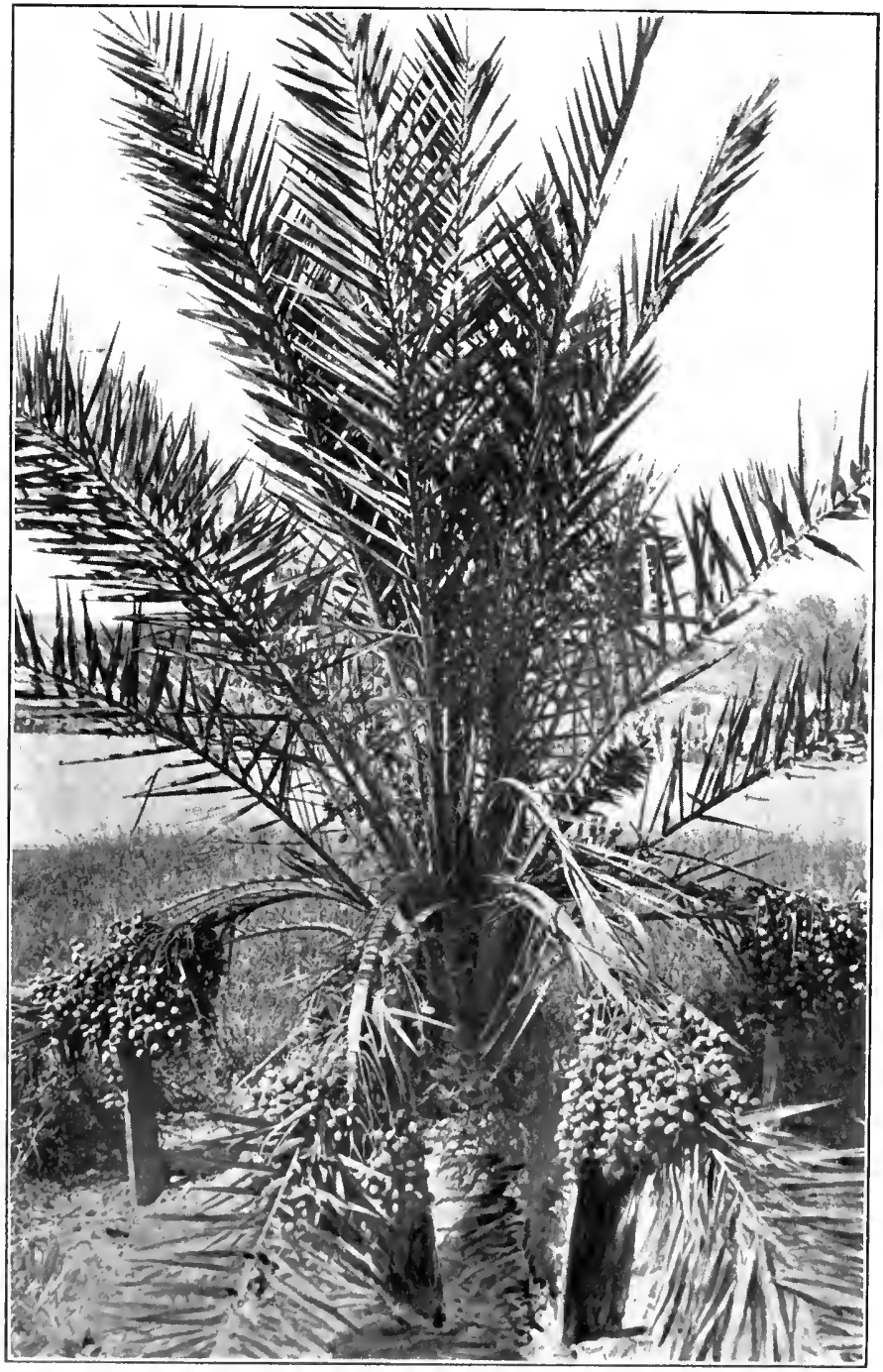

Date-palm tree, 6! years old, at Tucson. It was grown from a sucker. It is bearing its third erop of fruit, about 100 pounds 
West, the individual whose idea of developing the country is to cut every stick of timber off of it, and then leave a barren desert for the homemaker who comes after him. That man is a curse, and not a blessing, to the country.

When wood, dead or alive, is demanded in so many ways, and when this demand will undoubtedly increase, it is a fair question, then, whether the vast demands of the future upon our forests are likely to be met. You are mighty poor Americans if your care for the well-being of this country is limited to hoping that that well-being will last out your own generation. No man here or elsewhere is entitled to call himself a decent citizen if he does not try to do his part toward seeing that our national policies are shaped for the advantage of our children and our children's children. Our country, we have faith to believe, is only at the beginning of its growth. Unless the forests of the United States can be made ready to meet the vast demands which this growth will inevitably bring, commercial disaster, that means disaster to the whole country, is inevitable. . . . If the present rate of forest destruction is allowed to continue, with nothing to offset 


\section{THE NEW EARTH}

it, a timber famine in the future is inevitable. Fire, wasteful and destructive forms of lumbering, and the legitimate use, taken together, are destroying our forest resources far more rapidly than they are being replaced. It is difficult to imagine what such a timber famine would mean to our resources. And the period of recovery from the injuries which a timber famine would entail would be measured by the slow growth of the trees themselves."

While all indications point to a gradual national extension of the views of the President, resulting in checking forest destruction before it is too late, the work of the individual states in the period of the New Earth has itself been significant. Steps are being taken in many states to protect the forests from fire, to provide reserves, and to take advantage of the example of other countries in reforesting cutover areas; but perhaps the most interesting of all the developments is the creation of forests in states where thay have not before existed. I do not know that this can better be illustrated than by selecting the state of Kansas as an example of what is being accomplished, a prairie state beset with heavy winds, needing 
the protection of forest windbreaks and far removed from the timbered regions.

It was thirty-three years ago, in $1872,-$ a date which may not arbitrarily be chosen as the beginning of New Earth activities, as they lap over and interweave from past days, but which, nevertheless, fairly well indicates the beginnings of the new order, - that the experiment station of the Kansas State Agricultural College began the planting of forest trees. It was one of the first experiments of the station, though many species had been planted and propagated before. The experiment, as it has developed through the generation, has been rich in results. Many kinds of trees were planted, some of them with good promise of success, others essentially tentative. Land was selected least adapted to ordinary agriculture, high, gravelly and broken ridges, the object being to show the peculiar adaptability of trees to regions not needed for agriculture proper. Naturally, the growth was not so rapid nor so vigorous as it would have been on lower and richer soil, but the station authorities showed the soundness of their knowledge in making such choice. 


\section{THE NEW EARTH}

European larch, white ash, red ash, green ash, Osage orange, catalpa, ailanthus, black walnut, white hickory, soft maple and willow were first selected. Some of the trees were not successful, notably the European larch, but the others pressed slowly forward. Later came other trees, Norway maple, box-elder, hard maple, honey locust, coffee bean, Russian mulberry, cottonwood, Lombardy poplar, silver poplar, hackberry, plane tree and the sturdy oaks,red, black, bur, pin, shingle, yellow chestnut, swamp white oak and English oak among them. Then came the conifers, and here was shown one of the wisest steps in all the work. 'The station authorities held that "whether studied from the standpoint of the landscape artist, of the promoter who wishes to improve property for the increase in value, or from the standpoint of the stock-feeder who realizes that windbreaks save corn, and corn is money, the evergreens are to be considered as among the most beautiful and useful trees." Austrian and Scotch pine, white, pitch and 'Table mountain pines, cedars and spruces were the principal cone-bearing trees planted.

'The success of the planting of these forest 


\section{MODERN FORESTRY}

trees has been pronounced. Some of the pines have reached a height of over forty feet, being over a foot in diameter at the ground and from six to eight inches at six feet from the ground, while other trees have had equally satisfactory results. It has been demonstrated that even in a prairie state, far removed from mountain regions, the pines and other trees which we naturally associate with those regions may be raised at such a rate of growth as to make them profitable for lumber; while trees for mere ornament, for windbreak or fuel also make comparatively rapid and wholly satisfactory growth. Here, as in the work of the national government in preserving and extending the great standing forests, it is the future that must be looked to. 'The farmer of the New Earth who today begins the planting of trees upon his Kansas farm, in line with the information he may obtain free of cost from his state experiment station, through bulletins issued from time to time as the work has progressed, may not only live to reap handsomely himself from the tree harvesting, but he may be assured that all the generations following him will stand grateful debtors to him. 


\section{THE NEW EARTH}

And so it is going throughout the other states,-everywhere these beginnings of forests, following the splendid stimulations of the scientific men of the New Earth, who have so unselfishly been at work to spread among the people what may be termed practical knowledge, as distinguished from that which is eminently true and sound, but is not so arranged, digested and set forth as to be of real help to the people.

In addition to its own individual work, the Kansas Station has worked in coöperation with the Bureau of Plant Industry of the national government, both in planting trees and in testing tree seeds; the state, as well as the nation, thus reaping doubly from the experiments. Here all manner of problems incident to making prairie forests are worked out. The results are of marked aid to the service.

Kansas has been visited by disastrous floods, and forestry is being called into play to prevent them. In France, a century ago, forestry came to the aid of the people in a somewhat similar way. Along the French coasts, for centuries, the sand had been encroaching upon the fertile regions, converting them into a 
desert. "It was," in the words of Ambassador Jusserand of that country, at the meeting at which the President made the remarks quoted above, "like a death powder covering our land." 'Trees were set out to check the encroachment of the sands, and the country was reclaimed. So in Kansas, the plan of treeplanting along the sandy banks of streams that in high water overflow their boundaries is being followed, and the needed information is circulated among the farmers in the flood regions through the bulletins of the state experiment station. The cottonwood tree, a tree of very rapid growth, seems peculiarly suited for flood prevention. A thicket of cottonwood trees along the banks of the Kansas River grew so rapidly that, in twenty years, some of the largest measured over one hundred feet in height, two feet in diameter at the ground and a foot and a half in diameter twenty feet above ground. The average trees were seventy-five feet in height. Not only may these trees form a protection against floods, but, when harvested properly, afford a considerable revenue; for, though soft of texture, such wood is growing steadily in demand 
for packing-cases and barrels. The average price paid by dealers for this wood, for selected stock, is twenty-two dollars per thousand feet; while, for fuel, the cottonwood is worth three dollars per cord when oak is worth five dollars.

The flood land is generally so low that the roots of the trees find abundant moisture, and all the conditions are favorable to an ultimate and complete water or flood check. The banks once held in place, the water keeps its course, and the surrounding country is saved. In a single year, in 1903, in the Kansas region of the West, more than two million acres of land were covered with water, property was destroyed approximating forty million dollars in value, and nearly one hundred lives were lost. Not only were crops destroyed and vast damage wrought, but many fields had to be permanently abandoned on account of the washing away of their soil; while fertile fields on the lower lands were completely destroyed by the deposit of white sand from the floods, covering the land from a few inches to several feet in depth.

In addition to the value of the trees in preventing escape of water, they serve to break 


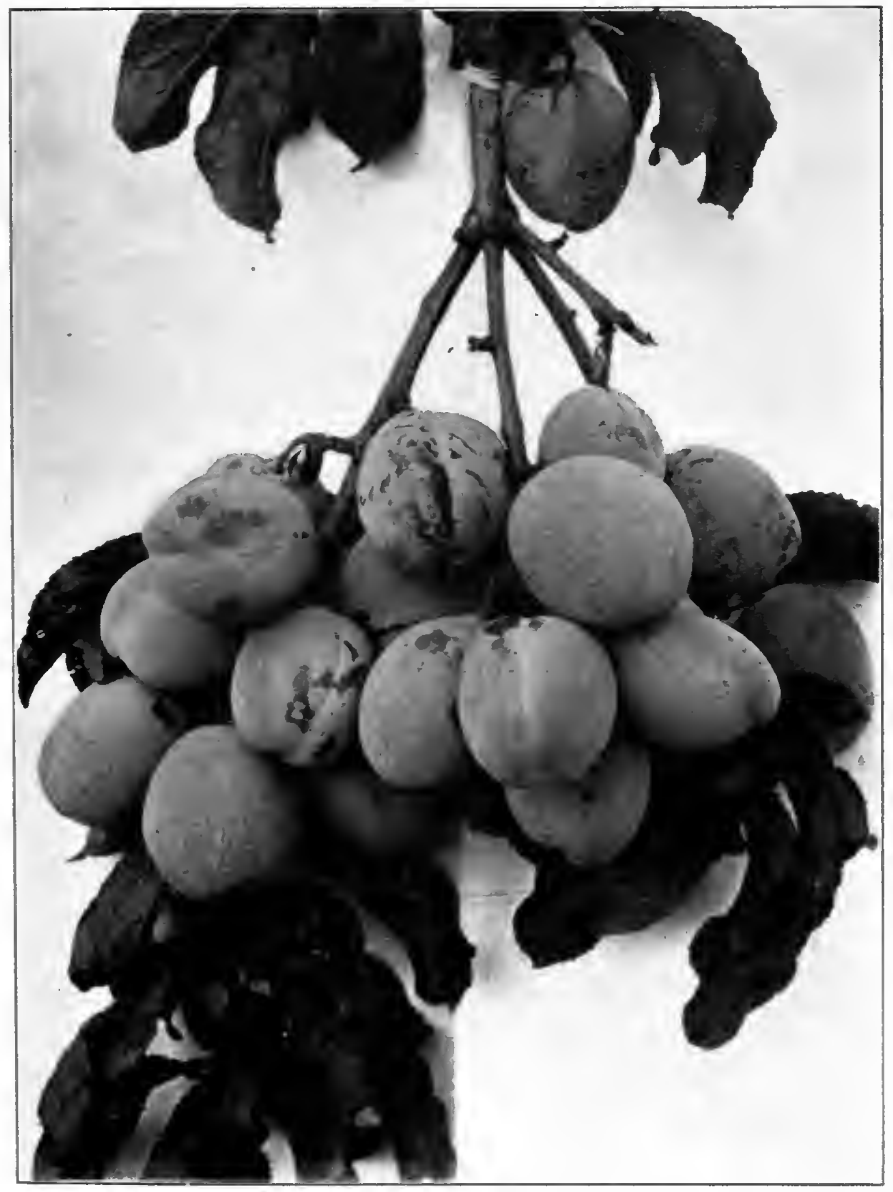

When the plums are ripe in California 

the wind ; and this is a most important factor, as the particles of rich organic matter in the sandy soils are, when dry, so light that heavy and constant winds blow them out of the soil and reduce its fertility.

Individual states, for the most part, have been lamentably slow in taking up the important work of forestry. An unwritten law has prevailed, one would think, providing that the forest must first be destroyed before any steps at preservation could be made. The frontiersman, opening up a new forest region, has seemed to have no conception of the value of the forest, and the greed of the timbermen has swiftly destroyed what the frontiersman left. Gifford Pinchot, in a bulletin issued by the government, calls attention to the fact that the early English settlers of America had been accustomed to a country where timber was already scarce, and where the penalties for its destruction were, severe and rigidly enforced. This bred a regard for the forest which later generations have not known.

In Nebraska, early in the period of the New Earth, Arbor Day was instituted by the Hon. J. Sterling Morton, later Secretary of Agri- 


\section{THE NEW EARTH}

culture. The chief feature of the day, the planting of trees by school children on a date fixed by the governor of the state, has had an important educational bearing. Provisions for the observance of Arbor Day have now been made in every state and territory.

In order to provide definite and recent information as to the efforts now being made in various states to preserve the forests, letters were addressed to the governors of a number of the states, and from their replies, or from replies prepared by departments of forestry, the following résumé of the situation in these states is made:

Colorado, as a state, has done little but pass laws. It has no machinery for their enforcement, no state forester, no office charged with responsibility relating to forests, no forest policy. 'The state experiment station has begun a series of coöperative experiments in tree-planting with landowners in various parts of the state. 'The national government has established forest reserves to the extent of nearly thirteen million acres, with three forest nurseries and a fourth soon to follow. Twenty thousand young pines were planted in 1905 , with very satisfac- 
tory results. A school of forestry has been established by private aid, embracing fifteen thousand acres of land known as Manitou Park, some sixty miles from the city of Denver, while the state agricultural college adds a course in forestry in 1906. The following suggestive words are from a leaflet issued by the Colorado State Forestry Association, an organization in the interests of forest preservation:

"On coming to Colorado, the first settlers found not less than thirty-six thousand square miles of forest area, much of which was heavily wooded with various kinds of valuable pines and spruces, the heritage of centuries, waiting for the miner, the farmer and the builder of cities, with promise of timber in plenty for generations to come. For many years no forestry laws were enacted. The woods were free for all, and at once became the prey of insatiable avarice and waste. By fire and wanton waste, thirty thousand square miles of virgin forests of the state have been destroyed, so experts say. If true, the enormity is unparalleled; for under no sky, in any land, by any people, civilized, or uncivilized, was there ever so much forest waste by a like number of inhabitants in 


\section{THE NEW EAR'TH}

so short a time. As a result of denudation, the snow melts early, the streams are impaired, the summer flow is lessened, farming is made more precarious, and water famines at times are threatened. Where deforestation is most extensive, the streams show the greatest degree of disturbance. All streams on the eastern slope are impaired, particularly Boulder, Clear Creek, Platte River and the Arkansas River. Beyond the range the same condition is rapidly obtaining,-- the Dolores, San Juan and Uncompahgre in a marked degree. Even the Gunnison and Grand are beginning to show the effects of deforestation. 'To every thoughtful mind it must be apparent that we are coming face to face with an alarming situation, demanding immediate and energetic action."

Nebraska has no laws for the purpose of conserving the interests of forestry. It has an Arbor Day, but the observance of this day is not compulsory, although it is strongly urged by precedent and gubernatorial proclamation. This is a prairie state possessing but little natural timber. However, the settlers have been very zealous in the matter of planting trees, and in the eastern half of the state nearly every 


\section{MODERN FORESTRY}

farm has its grove and suitable shade trees. 'The state is gaining in the matter of the number of acres devoted to tree-growing, rather than losing. In many parts of the state small groves are so numerous as to give the country an appearance of possessing much timber resource. There is no state in the Union in which Arbor Day is more faithfully observed than in this state. 'Thousands of trees are planted every year upon that day; but, of course, tree-planting is in no sense confined to that particular day. The people of Nebraska believe that an increase of forest growth has a direct influence upon climatic conditions, and hence the idea of tree-planting has been stimulated. Portions of the state are semi-arid, and if there is anything in the theory that treegrowth is an important factor in increasing humidity, that of itself is sufficient stimulus to promote the general planting of trees.

The General Assembly of Illinois, at its last (1905) session, enacted a law for the creation of forest preserve districts. The act contains a referendum to the people of any county or counties in the state desiring to organize a forest-preserve district under its provisions. For 
any district so organized, six commissioners are to be appointed by the Governor of the state, whose duty it shall be to administer the forest preserve law; and, in pursuance of this duty, the commissioners are empowered to designate by ordinance, streets, roads, avenues, boulevards and highways as public driveways, and may restrain and control the speed of travel on such highways and throughout such forest preserves. Comparatively little attention has been paid in the past either to the preservation or regeneration of forests in Illinois. A very considerable number of individuals have planted groves varying from one to several acres in extent, and some of these have succeeded well. In the aggregate, a very large number of trees have been planted since the settlement of the state began, but these have been mostly in shelter belts and in small areas upon farms, as well as along streets in the cities and the waysides throughout the country. The region of the state which was originally prairie proved to be well adapted to tree-growth, but since this land is desirable for agricultural purposes, no forest planting has been done. The Illinois Central Railroad has made some rather exten- 
sive plantings of the hardy catalpa for the purpose of procuring railroad ties. These were begun some eight or ten years ago and are doing as well as could be reasonably expected. Most of these catalpa groves, however, have been too closely planted for best results, as is very evident now. In the future these trees will not be planted nearer than eight by eight feet. Even then thinnings will have to be made in the somewhat early history of the plantation. Considerable European larch was planted twenty or thirty years ago, and there are now several very fine groves of it, though small in size. The black walnut, too, was similarly planted years ago, but here, again, the trees were set too near together and the development has been much slower than anticipated. This tree can hardly be said to have come into a marketable condition in any of these plantings. It is especially valuable only after it reaches a large size. The black walnut grows well enough in any situation in Illinois, and is esteemed exceedingly valuable for posts and railroad ties; but on the rich black loams, originally prairie, the trunk-boring insects destroy it, while upon the drier clayey or gravelly 
regions it is nearly free from these depredations. The growth in the latter locations is slower, but still it is a valuable tree for the purposes named. There is no reforesting of cut-over areas of any consequence, but something of this ought undoubtedly to be done, especially on the lands subject to overflows, along the Illinois and Mississippi rivers. In the southern part of the state, where the richest forest areas originally prevailed, scarcely anything but the destructive processes are in operation.

The University of Illinois put out, in 1871, -additions having been made during the following three or four years, - about twenty acres in blocks of from a fourth acre to one acre, of a number of different kinds of deciduous and evergreen trees. This was for experimental purposes, and the plantation is now showing some interesting results. The kinds that are now showing best development are hardy catalpa, European larch, white and buroak, green ash and white pine. The last has been somewhat surprising in its development, since it was planted upon a flat, not very welldrained area, having black loamy soil. More 



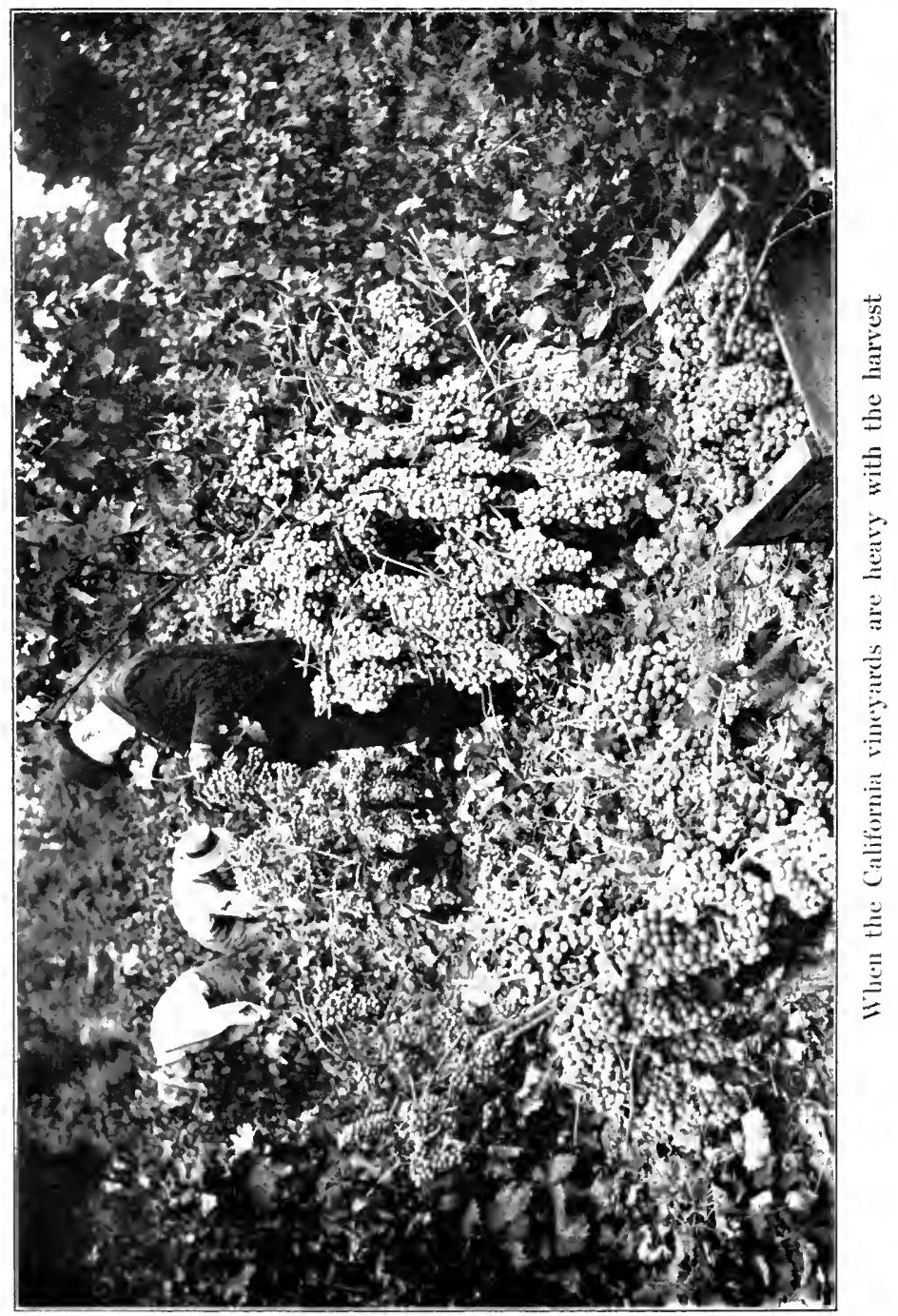


often this tree grows upon sandy soil. So far as commercial results are concerned, it cannot be claimed that there is hope in getting such returns as would have been secured from the usual agricultural crops of the region, but it is probable that ultimately the experiment will prove that such an investment would be considered fairly remunerative.

"The state of Alabama," comes the word from that commonwealth, "is doing nothing in the way of replanting denuded lands. We have still areas of forests, and our people are not as yet sensible of the necessity for re-supplying what is being taken away."

The state of New York, through its Forestry Department, has already undertaken, and is carrying on, extensive operations in the way of reforesting the waste and denuded lands in its forest preserve.

The work was commenced in a small way in 1901, at which time two plantations of white pine were made in the Catskill district. In the following year five hundred thousand young plants-white pine, Scotch pine, Norway spruce and larch-were set out on the burned plains near Saranac Junction, in Frank- 


\section{THE NEW EARTH}

lin county. These plants consisted of twoyear-old seedlings, and also of three- and fouryear-old transplants from the state nurseries. They were spaced five feet apart, the plantation including over seven hundred acres, as there were some swampy places on which no work could be done. 'The work on these fields was very successful and encouraging. Less than one per cent of the entire planted stock died; but these failures were replaced by live plants, and today there is not a blank in the entire plantation. At first these young trees grew very slowly until they recovered from the shock of transplanting; but they are now waist high, and it is expected that from this time on they will put on leaders each year from twenty to twenty-four inches in length. Their growth was very rapid in the summer of 1905, the leaders on most of the plants attaining the height mentioned.

In 1904, the commission made a large plantation of hardwoods on some of the state reservations near the Thousand Islands in the St. Lawrence River.

Last year (1905) still larger plantations were made in various places in the state forest pre- 


\section{MODERN FORESTRY}

serve, over one million plants of different coniferous species being set out. Most of the stock for this work came from nurseries which are maintained by the Forestry Department. But, as this supply was insufficient, the commission imported three hundred and fifty thousand white pine plants from a commercial nursery in Halstenbek, Germany.

It is the intention of the Department to continue this work each year, and increase its reforesting operations so far as the nurseries can supply the young stock. At present the capacity of the nurseries is insufficient for the proposed work; but new ones will be established as soon as appropriations can be obtained for that purpose.

The only thing Texas is doing with respect to its forests is in supporting a brief course of instruction in forestry at the state university, while the head of the school of botany is pursuing investigations into forest resources and various forest questions with relation to Texas, and publishing results of these investigations, with a view to creating general interest in forestry matters. Private interests are more or less taken up in one phase or another of for- 
estry, but receive no aid from the state. The last legislature had a forestry committee which reported in favor of a forestry commission, for the purpose of examining the forests of the state, to report a plan of procedure looking to the state's taking active part in certain forestry plans. This bill passed the House of Representatives, but did not reach the Senate early enough in the session to receive consideration. Doubtless it will come up again in the next legislature.

Oregon is not doing anything in the way or reforesting cut-over areas, or in making new forests, or in farm forestry generally. On a small scale, however, many of the farmers in the irrigated districts in the eastern portion of the state are setting out some trees on small bodies of land, but this is being done on such a small scale that it is hardly worth mentioning.

An act was passed by the last legislature of this state providing for the protection of forests and timber of the state against forest fires, and, to that end, providing for the appointment of fire rangers and defining their duties, stipulating for a closed season and providing for the punishment of persons who set 
out fires which cause, or may cause, injury to forests or timber, and providing penalties for violations of the several sections of the act. Aside from this, practically nothing has been done by legislation or by private enterprise in this state. It must be borne in mind, however, that nearly one-fifth of the area of Oregon is included within forest reservations, by authority of the President acting under laws of Congress.

Some advance along the lines of protection of forests in Ohio has been made, favorable action toward which Governor Herrick recommended in his first message, and will do so again in his message to this legislature, 19051906 , asking them to form a bureau in connection with the Good Roads Commission.

North Dakota is distinctly a prairie state, but efforts have been made to encourage the forestation of treeless areas. 'This work is being done, in a measure, through the State Agricultural College, which is encouraging the planting of trees for shelter about farm homes, and some progress is being made. At the last session of the legislature a tree bounty was provided, of three dollars an acre, to every 


\section{THE NEW EARTH}

person who shall hereafter plant, cultivate and keep in a growing condition one acre, and not more than ten acres, of prairie land with any kind of forest trees, which bounty shall be paid in the way of a reduction of taxes levied against real estate to that extent. Every person planting forest trees suitable for hedges along public highways is entitled to an annual bounty of two dollars for every eighty rods of each row in length. It is hoped that these provisions will, to some extent, encourage the forestation of treeless areas.

In Kentucky, up to this time (1905) no legislation has been made looking to the preservation of the state's forests, except a private organization called the State Forestry Association. At the last session of the legislature a bill was introduced looking to state aid for this association, but it did not pass.

Idaho is a very young state, and its laws are still in process of formation. 'The state owns a great deal of forest lands, and at the last session of the legislature a bill was passed which provides for the perpetuation of the state's forests. Hereafter only merchantable timber will be sold, and the purchaser will be required 
to clear away all stumps and branches, lessening the danger from fire, and placing the forest so that within an appreciably short time the timber value will be renewed.

In 1887, the Kansas legislature enacted a law creating the office of forest commissioner, to encourage the planting and growing of forest trees. 'Two tracts of land were secured, upon which experimental forest stations were established. The law provides especially for such trees as should be particularly adapted to the plains region of the state; the trees grown, when ready for transplanting, being issued at the two stations to all residents of the state applying for them. From fifteen hundred to two thousand five hundred applications have been filed yearly since 1888. Commissioner of Forestry Beaubien says regarding results:

"Where ten years ago there was but the open expanse of sky and grass, until the eye grew weary of the never-ending monotony, today can be heard the song of the mockingbird and the thrush as they nest and rear their young in our artificial forests. This has been accomplished without artificial irrigation."

The state of Pennsylvania now owns and 


\section{THE NEW EAR'TH}

has under forestry control five hundred and sixty thousand acres of timber land, chiefly located in the central portion of the state. As an illustration of the effectiveness of state supervision in the one matter of fires, it is shown that while there were probably three thousand deer-hunters upon the reservations of the state during the month of November, 1904, - the deer-shooting season,- - not a forest fire was reported from this source. A forest academy, under the direction of the state forester, has been established. With all efforts to preserve the forests, the rate of cutting still remains greater than the rate of reproduction. One of the very interesting features of forestry in Pennsylvania is the encouraging of the planting and cultivation of osier willows for use in manufacturing baskets for an indefinite number of purposes,-wicker furniture, carriage and automobile bodies, and so on. With the rise in wood values, boxes made of wood for shipping purposes become more expensive, and the willow baskets admirably take their place. 'The Department of Forestry in Pennsylvania makes note of one hundred and sixty-eight varieties of willows, and suggests 


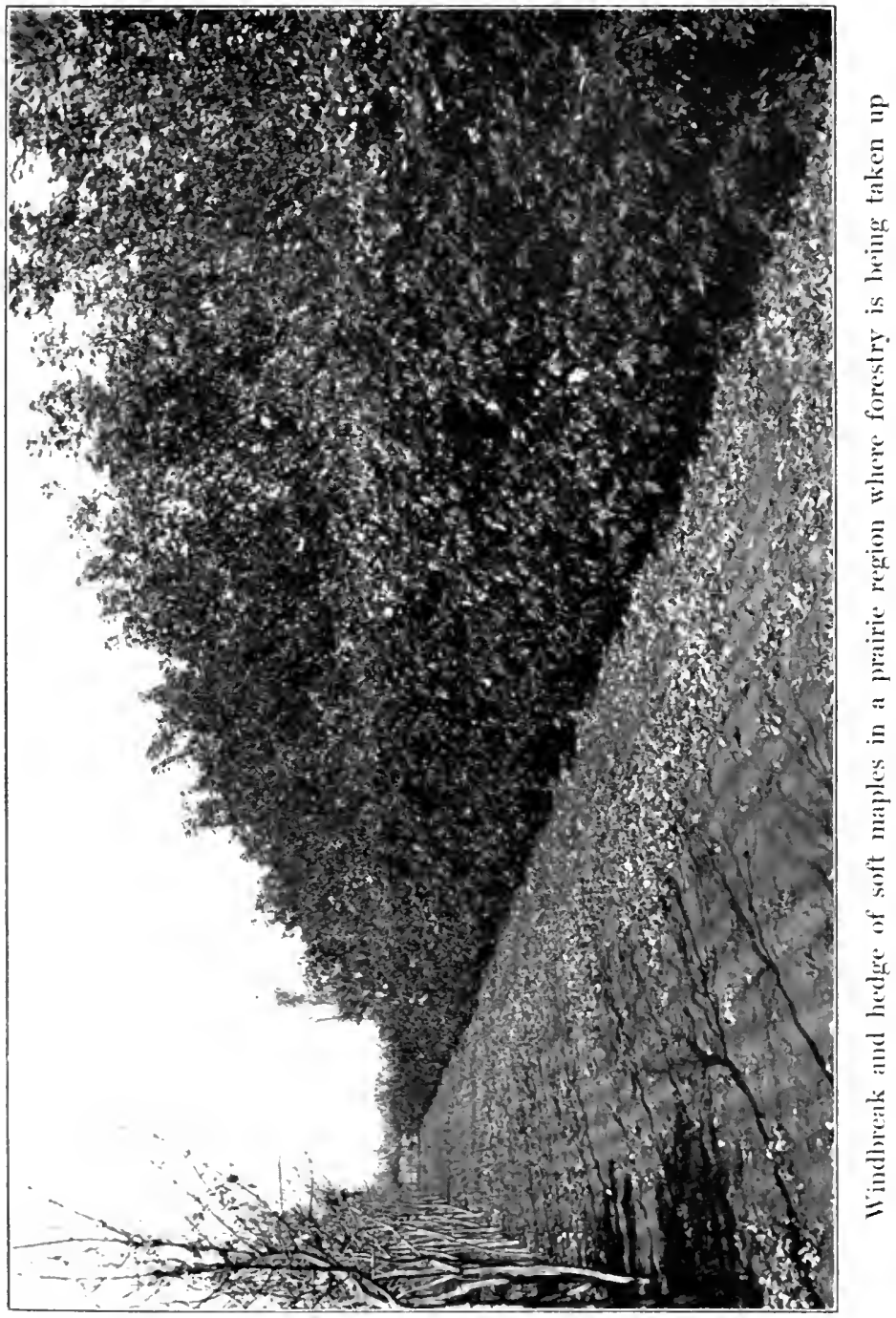





\section{MODERN FORESTRY}

the more important ones which may be planted on vacant and otherwise unproductive land, and be made to yield a good income. Ample directions are given for the planting and care of willow plantations.

In the period of the early history of Indiana, that state was heavily timbered with forests of hard woods. 'The forests rapidly disappeared when the farmers came, and it was not until the year 1900 that forestry became a matter of state concern. 'The almost complete absence of virgin forest in the state and a general timber scarcity were sharply brought home to the people, and a hearty response for forest improvement followed. A State Forestry Board was established in 1901, consisting of five members, one to be chosen frum the State Forestry Association, one from the Retail Lumber Dealers' Association of Indiana, one from the faculty of Purdue University, one from the skilled woodworkers of the state, and one having knowledge of timber culture and of forest preservation,--all, save the last, known as the state forester, to serve without compensation. 'Two years after the establishment of the board, over thirty thousand trees 
nual growth of spruce in the state warrants the cutting of $637,000,000$ feet per year without depleting the supply. 'The pulp mills consume about 275,000,000 feet of spruce per year, leaving for general sawmill purposes $362,000,000$ feet of spruce without encroaching upon the legitimate growth of the forests. It it thus shown that with proper fire protection and with careful harvesting there is ample spruce in the state to supply a large demand indefinitely. Even when the land has been ravaged by the thoughtless lumberman, the undersized trees left standing furnish another crop in a comparatively short time. In 1903-04 the legislature of the state made an appropriation for public instruction in forestry, this instruction taking the form of a forestry course in the University of Maine. The course embraces general forestry, forest botany, including field and laboratory work, forest measurements, lumbering, forest management and the like. There is a major course, which requires four years, leading to the degree of Bachelor of Science in Forestry.

It took fully a quarter of a century in Michigan to develop forestry interest. As President 
Garfield, of the Michigan Forestry Commission, puts it, very little headway was made until the bulk of the forests was practically gone. It was only when the farm wood-lots were reduced to a minimum, when industries dependent upon the forests for raw material began to leave the state, and when the rivers of the state began to wane, that interest in forestry could be aroused. 'Though once one of the leading forest states, it was not until 1899 that a forestry commission was appointed, having little authority and very little funds. Later, forty thousand acres of state lands were set aside for the work of the forestry commission, a forest nursery was established, and a million trees, in 1906, were ready for planting. A department of forestry in the state university and in the state agricultural college has been provided, and courses of lectures on forestry are projected for the state normal schools. About one-third of the area of the state is stripped of timber and burned over, every acre of which, according to the forestry commission, might be reforested. More than six million acres of this region have become state tax titlelands. A most earnest effort is now being 


\section{THE NEW EARTH}

made to arouse general interest in forestry and to redeem the state from the sad condition into which it, with other commonwealths, has fallen by reason of the thoughtlessness and the rapacity of those whose duty lay in providing for the future.

Some three hundred thousand acres of state land in $W$ isconsin are now included within the forest reserve. 'The chief object is to protect the headwaters of the important rivers, and reserve a supply of timber for the industries which are dependent upon the forests for their raw material. State Forester Griffin says, regarding the outlook:

"Until we have secured the necessary land, and in a compact body so that we can build fire lines and protect it from fire, we shall probably not do any planting, except on small tracts where the land is unusually clear from slash. At the next session of the legislature, we shall probably attempt to pass a bill exempting from taxation lands which are planted with forest trees, at least twelve hundred to the acre, so as to encourage reforestation both by lumber companies and farmers. Many of the lumber companies are practicing a more or 
less rough system of forestry, and I think that the interest in the work is increasing throughout the state."

In all of the states where forestry is now being so zealously studied, the question of fire protection and fire prevention is being considered as one of paramount importance.

But important as is all the work of the individual states in the production of forests, one of the most important advances promises to be in the creation of new and fast-growing trees along the lines laid down in the experimental work of Luther Burbank, the great plantbreeder. Mr. Burbank has demonstrated that trees can be bred for any particular quality,for largeness, strength, shape, amount of pitch, tannin, sugar and the like, for rapidity of growth; in fact, that any desirable attribute of a tree may be developed simply by breeding and selecting. He has created walnut trees, by crossing common varieties, that have grown six times as much in thirteen years as their ancestors did in twenty-eight years, preserving, at the same time, the strength, hardness and texture of their forebears. The grain of the wood has been made more beautiful at the 
same time. In twelve years' time, without irrigation, these trees have grown to be eighty feet in height, with a branch spread of seventyfive feet, trunks nearly three feet in diameter at the base and nearly two feet in diameter at fifteen feet from the ground. The trees are fine for fuel and splendidly adapted to furniture manufacture. This demonstration of the possibility of tree-breeding places an entirely different aspect upon forestry the world over. It points the way, too, to the reforesting of the denuded areas of the earth at a pace far more rapid than any ever before known. By constant selection of those seedlings of a certain cross, or of a variety not crossed, which show unusual rapidity of growth, this particular quality of rapidity is attained, the descendants of these seedlings continuing the rapidity of growth as soon as enough time has elapsed to fix them in their course. So in the case of any other attribute, the seedlings, which, as they develop, show in larger measure the attribute sought, are the ones selected for the fixing and preserving of this larger measure of excellence.

While in the generation of the life of the 



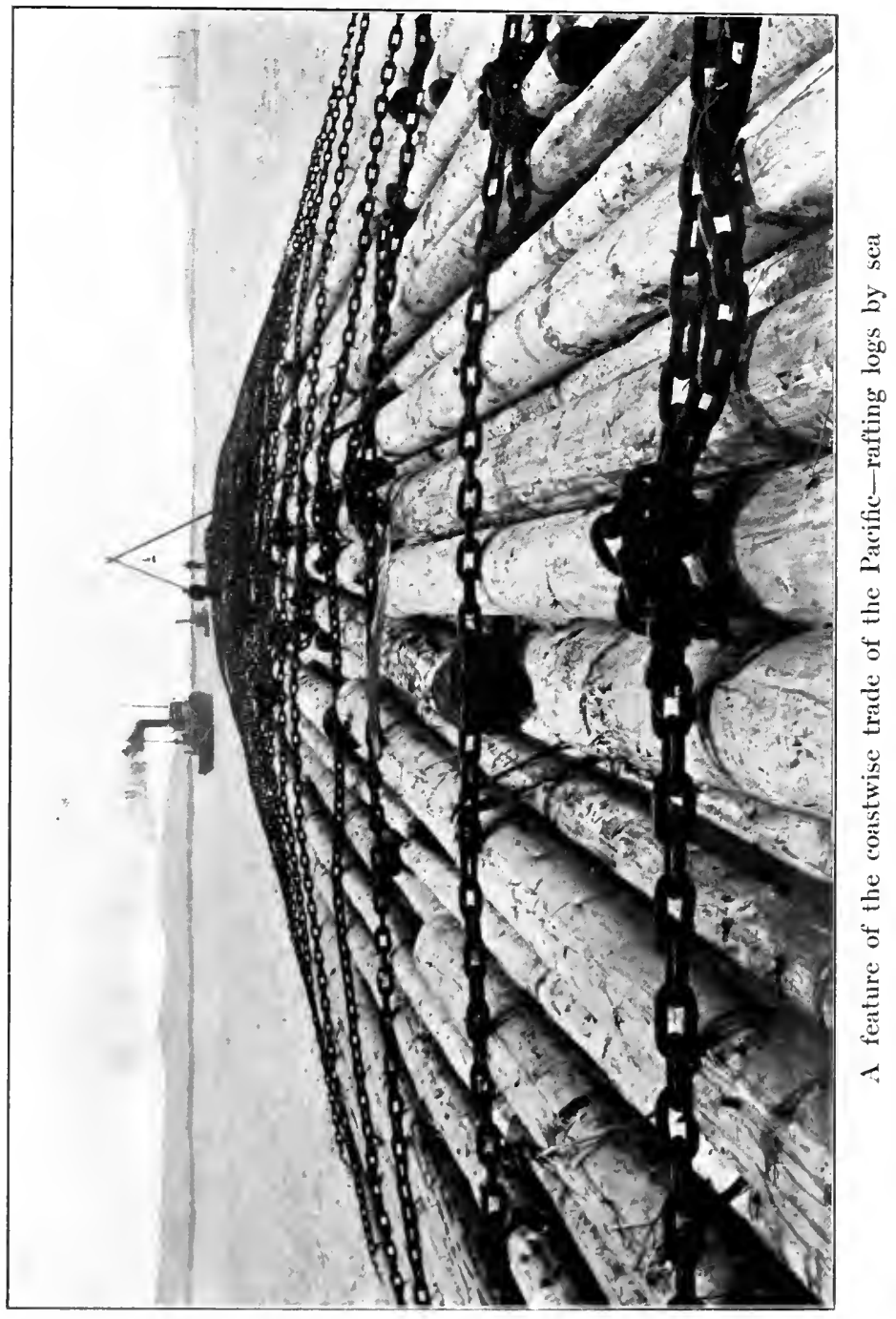




\section{MODERN FORESTRY}

New Earth great progress has been made in forestry, both national and state, the work now under way by the nation and by individual commonwealths, taken in connection with this remarkable demonstration of the power of man to create trees practically at will, makes the future fuller of promise by far than the past. In no one of the various lines of life that take their rise in the earth has there been greater need of earnest and progressive action in this present revival of knowledge, or this creation of knowledge, if you will, than in this one of forestry: in no line has a greater energy been set in motion. 


\section{CHAPTER XI}

\section{MODERN DAIRYING}

BOUT the time that the activities of the A New Earth were set in motion, the staid folk of a picturesque Swedish hamlet, and those along the country roads in the vicinity, used to derive no end of amusement from the visits of a lad from the village who was accustomed to go from house to house asking for the privilege of repairing things, - old watches or clocks, jewelry, and the like. $\mathrm{He}$ was not seeking profit but pleasure, for he had an inborn delight in doing such things. In case there was a broken tool of some kind, a door-knob or knocker out of order, - -anything, in fact, that needed tinkering, - - he begged to be allowed to put it in shape. So the country folk, goodnaturedly, humored him, and the defective articles were soon made whole. The fame of the lad spread, and great things were prophesied of him as an inventor. When a little older, he produced a number of quite impor- 
tant labor-saving devices, among them an automatic cow-milker, which aroused no slight interest among the country folk.

I do not know whether or not it was this latter that turned his attention to the invention which brought him fame and money, but, in any event, he became convinced that the old way of allowing milk to stand until the cream had risen was not the best way. So he set about perfecting a device for the mechanical separation of cream from milk. The invention was a simple one, the act itself so natural, so to say, it was curious that no one had ever hit upon such a thing before. Though simple, it has yet proven one of the wonderful inventions of the age, the de Laval separator. For it was the great Swedish inventor-whose fame rests by no means on this derice alone - who was so greatly admired as a lad by the country folk, when he turned tinker among their disabled household articles and kept the community in repair.

De Laval's invention is one of the most important contributions made to the life of the New Earth. Without it, modern dairying could never have attained its present com- 
manding position. These little machines that take the milk fresh from the cow, whirl it about with great rapidity, separate the milk from the cream, and send the former foaming out through one spout,-the cream, at the same moment, escaping through another spout,- - have exerted an immense economic influence. It would be idle to attempt an estimate of the millions of dollars that have been saved, in time, labor and actual expenditure of money. Not only this, but the saving in material has been great. In an average herd of well-kept, well-bred cattle, the milk will probably average four per cent of fat; that is, there will be four per cent directly convertible into butter. Under the old method of setting the milk in shallow pans for the cream to rise, not all of the cream was obtained, fully one-half of one per cent remaining in the milk, so that one-eighth of all the butter-fat was lost for butter manufacture. Under the new method, a first-class separator should not leave more than one-tenth of one per cent of the cream in the milk, perhaps not so much as that. 'The importance of the invention is still more clearly shown in view of the fact that, under the old order of things, some 


\section{MODERN DAIRYING}

farmers set their milk in deep cans in tanks of ice-water for the cream to rise, losing thereby six to eight per cent of the total amount of fat, practically all saved by means of the separator, using the milk direct from the cow.

It is of interest to note that in the whole of Sweden, where his inventions have placed him in popular estimation among the foremost men of his generation, Gustaf De Laval is held in just as high esteem as he was in the hamlet in those early days when he won the hearts of the good housewives. He is a man with a prodigious capacity for labor, as shown not only by the number of his other inventions, but by his success in the development of great industries. 'Though an inventor, he has shown marked business ability, having amassed a fortune. He is pronounced a man of the most delightful attributes, unspoiled by successes, of great strength of character, of most charming personality.

But while, on one side the Atlantic, one man was developing an invention that was to prove of such great value to the dairy world, another man on this side the sea was perfecting another invention destined to play an even greater part 
in the production of the world's dairy supplies. Indeed, even with the mechanical separation of the butter-fat from the milk, modern dairying could never have reached its present plane had not an American; Dr. S. M. Babcock, of the University of Wisconsin Experiment Station, invented a machine for the determining of the amount of butter in milk, without waiting for the cream to rise or for the milk to be separated from the cream. Dr. Babcock had long been making investigations in the line of the dairy, when he one day hit upon a plan for testing milk for its butter-fat. 'The device which he made for the test, also, like most other important inventions, a very simple affair, was merely a tin receptacle like a pan in shape, with a cover to.it, on the inside of which were compartments to hold several small bottles. By means of a simple crank and wheel, the pan holding the bottles could be made to revolve rapidly.

He placed milk in the little bottles, along with a small portion of sulphuric acid. This acid would dissolve all the solids in the milk save the butter-fat. When the pan was rapidly revolved, the butter-fat was forced upward from the milk into the narrow neck of the bottle, 


\section{MODERN DAIRYING}

upon which there was a graduate to measure the amount of fat lodged there as a result of the rapid whirling. It was easy to read the scale in the neck of the bottle, and from it to compute the amount of butter-fat in the milk from which this was taken as a sample. It was all such a simple thing from one point of view, but it was of tremendous importance, simple though it seemed, judged by its bearing upon one of the world's great industries.

It was quickly apparent, as the news of the invention spread, that a new era had dawned in dairying. Hitherto milk had been sold with no reference to its quality. The rich product of the best herds came in unfair competition with the milk from poorer herds, or with milk which had been diluted with water or otherwise adulterated. Under the new order of things, all milk must sell upon its own individual merits. No matter how many pounds of milk a farmer, for example, might bring to his local creamery, he was not to be paid, any longer, by the quantity but by the quality. It made a complete revolution; like many another revolution, it was an evolution also.

Today the Babcock milk test is adopted by 


\section{THE NEW EARTH}

the dairymen of all nations. It is proving of great value. It is estimated that in his own state, Wisconsin, the saving per year by its use is fully a million of dollars, while a single syndicate, comprising one hundred and thirty creameries, according to the testimony of its manager, saves at least one hundred and fifty thousand dollars a year by means of this test.

'These two men have not only made modern dairying possible, added enormously to the wealth of nations, and been of large service in relieving man of toil, but they have opened the way to an indefinite expansion of the dairy industry, so that they are contributors to the wealth of posterity far more than to that of the generation in which they live.

Without drawing any unfair distinction or casting any discredit upon Dr. De Laval, it may be said that the invention of Dr. Babcock takes on a peculiar interest in view of the fact that, though he might have amassed a colossal fortune had he taken out a patent upon his invention, he yet gave it to the world as the other remarkable results of experiment station work have been given to the world, free of all cost, -a significant and commanding illustration of 


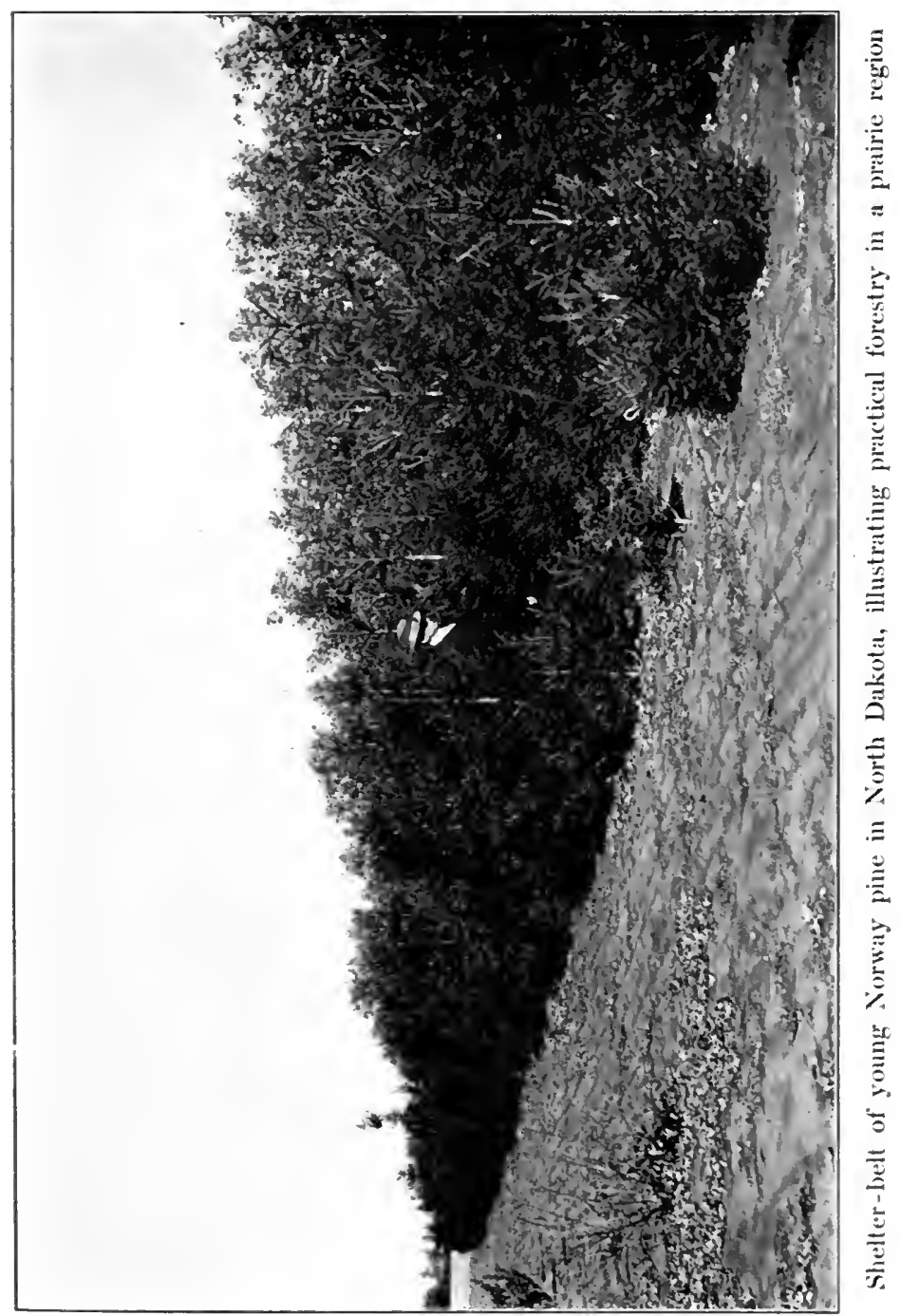



the fact that unselfishness is not yet dead among men.

But Dr. Babcock, like De Laval, has not confined his efforts to one line, though the benefit derived from his other discoveries, like that of the milk test, has been public, not private. He has made exhaustive studies into the composition of milk and other substances, always having in mind the practical bearing of the work. He invented the viscometer, by means of which the viscosity, or the amount of glutinous or sticky substances in oils might be determined; devised a method of analyzing milk which has been accepted as the standard by the official chemists of the United States, and is largely in use in Europe; discovered a method for determining the number and size of the fat-globules in milk, and a method for the mechanical separation of the casein in the milk from the other constituents. In connection with Dr. $\mathrm{H}$. L. Russell, also of the Wisconsin station, he made an important discovery, finding a digestive ferment in milk, an enzyme, resembling the secretions of the pancreatic organ of animals. This ferment has been given the name "galactose." 'The discovery is among the most im- 


\section{THE NEW EARTH}

portant in the history of the New Earth. It was found that to this agent is largely due the ripening of cheese. It was formerly believed that this ripening, or curing, was due to bacteria, and it was also believed that cheese must be ripened at a high temperature. The very opposite has been found to be the case, the cheese cured at low temperature, beginning below freezing and rising somewhat above, being richer in flavor and having less shrinkage in weight. The old-fashioned curing-rooms are thus rendered unnecessary. Several hundreds of dollars may thus be saved in the construction of every cheese factory. 'The two also discovered, or devised, what is known as the Wisconsin Curd 'Test, by means of which impurities, as dirt or bacteria, may at once be determined in milk. The test is of great aid to cheesemakers.

Other practical scientists in this country and Europe have been giving close study to the dairy. In the United States the experiment stations are putting forth many bulletins which, though they have a limited circulation (each station's publication going chiefly to the people in that state, and thus preventing a 


\section{MODERN DAIRYING}

diffusion of bulletins on the same subject from other states), are yet of marked value.

'These bulletins present some curiously interesting information, some of which may be here indicated.

In Iowa, for example, a state with large dairy interests, a recent bulletin shows in entertaining fashion that the dairymen of that state could sell four hundred thousand dollars' worth of water in their butter each year, if they would only conform to the standard the butter-using countries of Europe have established. England, referred to as the greatest butter-using nation, with other European nations, wants butter having sixteen per cent of water. 'Tests made in a single year, 1902, of eight hundred samples in four hundred creameries distributed over eighteen states, developed the fact that there was an average of eleven and eight-tenths per cent of water in American butter. In Iowa alone, the change to sixteen per cent would result in increasing the yield of butter each year about two millions of pounds, "which would mean," in the words of the bulletin, "a financial increase to the dairymen of Iowa of about four hundred thousand dollars, 


\section{THE NEW EARTH}

without the investment or the expenditure of a single dollar."

"It should be distinctly understood," the bulletin continues, "that the writers do not favor an excessive amount of moisture in butter, but since the world's best commercial and scientific butter judges, when viewed by them from the consumer's as well as from the producer's standpoint, have fixed the maximum standard of moisture in good butter to be sixteen per cent, it is a matter of business for the producers to come as near to this standard as possible."

The studies in bacteria as they relate to milk have been exhaustive, and many interesting developments have followed. One investigator, noting the size of the bacteria that appear in milk, says that if they could be increased to the size of baseballs, and a man should be increased in the same proportion, he would stand over fifty miles high.

When the milk lies in the udder of the healthy cow, it is germ-free, but the moment it is exposed to the air there is danger of contamination in a thousand and one ways, for the bacteria abound in air, earth and water. 


\section{MODERN DAIRYING}

For some reason, the milk that is fresh from the cow is particularly susceptible to the bacteria, and their development in milk proceeds with remarkable rapidity. At the Maryland station, many tests have been made. In a single cubic centimeter of milk, say about onefourth of a teaspoonful, in one test where the milk was first set in water standing at sixty degrees Fahrenheit, held for fifteen hours and then cooled until the milk stood at the same temperature, 7,000 bacteria were found in the cubic centimeter of the fresh milk, 2,500,000 at the end of fifteen hours, $69,000,000$ at the end of twenty-four hours, and 300,000,000 at the end of thirty-nine hours, - suggesting their marvelous reproductive powers.

'The effect of the bacteria upon the milk is to cause it to sour, to make it less wholesome for invalids and children, and, often, to impart to it a disagreeable flavor. While there are bacteria known to be beneficent and aidful to man, there can be no question that those which so rapidly develop in milk carry death and disease. If disease does not follow the use of impure milk, it is because the system into which it is taken is strong enough to resist. 


\section{'THE NEW EARTH}

One writer goes so far as to say, "Any milk which shows a sediment on the bottom of a transparent vessel upon standing one hour is not fit for human food."

But reform in methods since the New Earth began, and particularly in the last ten years or less, has done much to safeguard the health of the people. Dirt has been shown to be unprofitable, as well as dangerous to health. The untidy milkman of the old order of things finds himself left behind in the race. All manner of dirt-excluding devices, searching inspection of suspected dairies, with official warnings that cattle must be kept clean and stables clean and utensils as nearly immaculate as soap and water will make them,- - these have all had their bearing. 'The fact that the Illinois State Dairymen's Association, at their meeting held at the agricultural college of that state, sat down not long ago to an elaborate lunch in the cow-stables of the college, at a long table extending down the center of the stables, from which the members could all but touch the stalls from their seats, and all with no offense to sight or smell, suggests how the new order of things is displacing the old. 


\section{MODERN DAIRYING}

Right in line with the necessity for cleanliness in the products of the dairy, particularly milk, is the necessity for standardization of milk. There are over eighteen million cows in the United States. It is estimated that onethird of all the milk they produce is sold for direct consumption. Wilbur J. Fraser, chief of the Dairy Husbandry Department of the Illinois Experiment Station, after seven years experience in conducting a sanitary dairy at the University of Illinois where the milk is bottled and sold for direct consumption. makes these five points: 'The consumer has a right to demand that the milk delivered to him shall be clean; that it shall keep at least twenty-four hours after delivery if held at a temperature of 60 degrees, or below ; that the flavor of the milk be not impaired by improper feeding, careless methods in handling, or by the development of bacteria which cause bad flavors that the milk be not injurious to health-i.e. that it contain no disease-producing germs, or any form of preservative; and, last, that the milk shall have a certain known composition which is uniform from day to day.

The last condition, one of the most impor- 
tant of all, comes under standardization; and this can be absolutely complied with by means of the Babcock test. The producer can tell, if he will, precisely how much butter-fat his milk contains, simply by making a test to that effect, labeling his bottles to correspond. Upon the quality of his milk, not upon its quantity, should depend his price. Every quart of milk' sold in the United States could be brought under this test. If such a thing were done, the producer, no less than the consumer, would be protected; the general health of all adults using milk would be safeguarded, while one of death's easiest avenues of approach to infant life would be effectively blocked.

Another and very interesting phase of the dairy life under the new order of things developed in these stations, is the individual testing of cows. A regular account may now be kept with each cow. She can be compelled to show her precise value. If she does not come up to a certain grade of efficiency as a milk-producing machine, she can be improved by a different ration, or by different care if she has been neglected; or, if she cannot show fitness, she can be discarded from the herd altogether. 


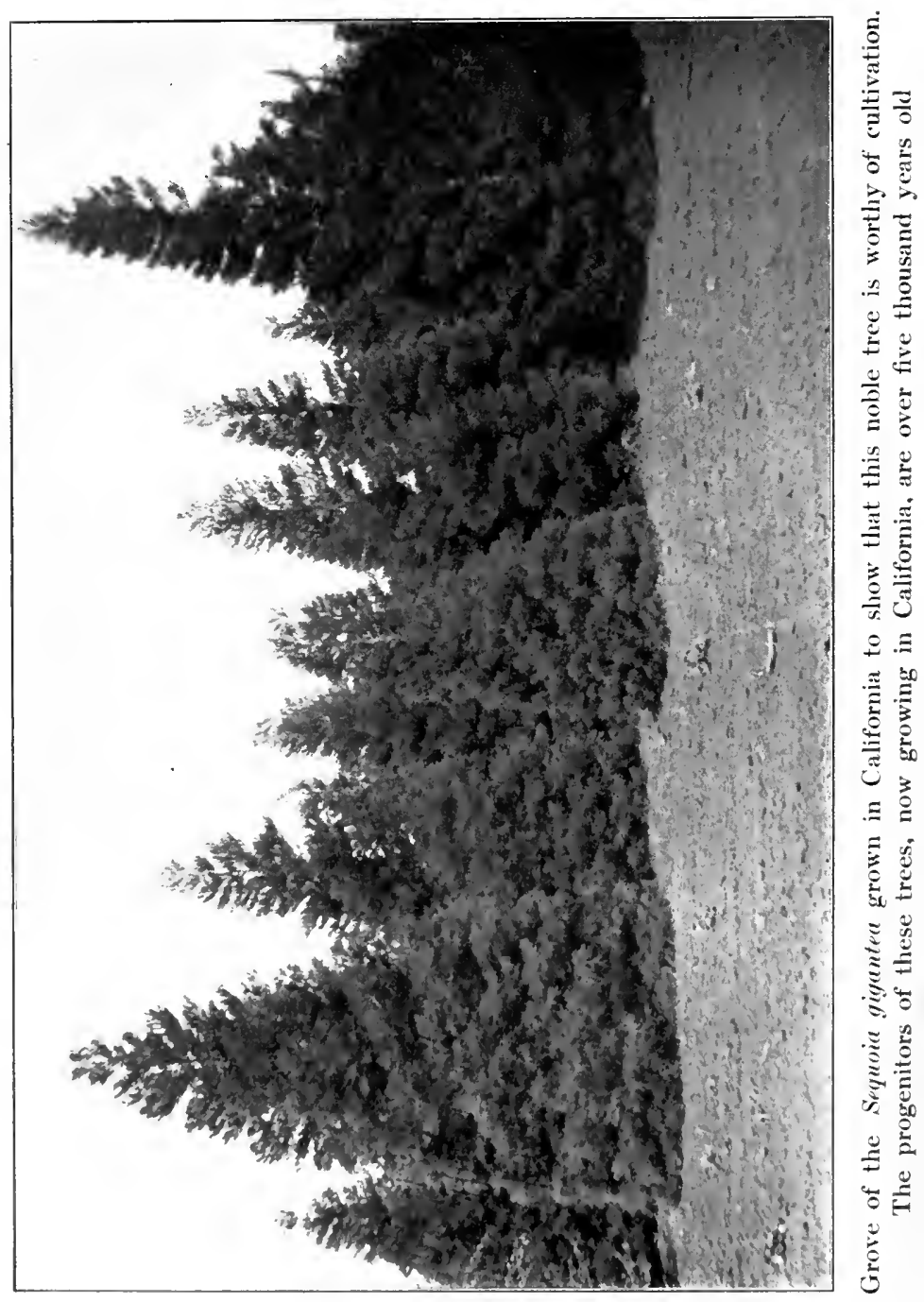


\section{MODERN DAIRYING}

Exhaustive studies are being made at many of these stations into the food of the cow, in order that the best possible results may be obtained at the least possible expenditure of money. So, in a model herd under test an account is opened with each cow. She is charged with what is fed her, credited with what she produces. A careful record is kept, showing her milk product per day and the quality of the milk per day, week and month. At the end of the month, the check sheets in which her name, or number, and her product are recorded, tell precisely what she is doing.

In one station, check was kept upon a series of ten herds of cattle in different parts of the state. In one herd, the best cow gave 8,230 pounds of milk in a year; her per cent of fat in the milk was 5.03 ; she made 483 pounds of butter. The poorest cow in the same herd gave 1,986 pounds of milk; her per cent of fat was 4.78 , and she made only 111 pounds of butter. By means of this elaborate checking the value of a dairy cow can be accurately told-her pedigree and her breed are important, but are less important than her milkand butter-producing powers. 


\section{THE NEW EARTH}

Along with this has gone a diffusion of information as to the care of the herd. At the Storrs Station in Connecticut, tests have been made with a covered pail which admits the milk through wire gauze of fine mesh, to which are added layers of cheese-cloth. Prevention of impurities is thus secured. 'The amount of dirt in the milk from the covered pail was only thirty-seven per cent of that in the open pail; in other words, the cover excluded sixty-three per cent of the dirt. In addition to this, by the use of the covered pail, twenty-nine per cent of the total number of bacteria and fortyone per cent of the acid-producing bacteria were excluded from the fresh milk. Where the milk was drawn from the cow into an open pail and then strained, the results were by no means so satisfactory. In this connection, the filtering of milk as practiced in Europe is worthy of note. In Vienna, the filters are large drums of sand through which the milk passes, either being forced up through the sand from the bottom, running out over the top, or passing down through the sand by gravity. While practically the entire milk supply of the city of Vienna is filtered through 


\section{MODERN DAIRYING}

sand and while fine results are obtained in filtering water through as deep layers of sand as this milk passes through, yet it is pointed out in a bulletin issued by the Maryland Station that such filtering of milk does not by any means give as good results as might be expected. "Milk" as the bulletin puts it, "has a strange affinity for dirt and seems loath to give up that which it holds in suspension. A peculiar exposition of the characteristic of milk was noticed in some work done at this station in trying to remove the garlic odor from milk. The milk was filtered through bone-black, but came out as black as the charcoal through which it had passed. Water, made turbulent by the finest clay, was run through this same filter and came through clear as crystal. It was finally found that charcoal, granulated and washed as free from dirt as possible by agitating in water, would still cause the milk to turn black when run through it. To this same characteristic is very likely due the fact that the best sand filters will not remove all of the dirt from the milk. Filters seem never to have come into use in this country, or there has at least never been 


\section{THE NEW EARTH}

any report of their use as far as could be found. It is very likely that if ever the cities of the country control the handling of the milk sold within their limits, the sand filter will be used as it is in Europe, providing some better means has not by that time been found for purifying milk."

In some ways, the most important change wrought in dairying during this period of the New Earth has been in the freeing of women. If there ever was a distressing white slavery it was that which bound the farmer's wife and daughter to the churn. Before this period, many farmers' wives were expected, in addition to all their other duties, to care for the milk, attend to the skimming of the cream, churn the cream into butter, and laboriously "work" the butter until it was ready for market. Not infrequently the milking of the cows fell to their lot also. The work was heavy and hard. It aggravated ailments to which overworked and underfed women were liable. It made life a burden. It shortened many a woman's life. And, sad fact that it was, the product which she turned out, after the most faithful labor, was often, through lack of 
knowledge, a most wretched product, unpalatable, unwholesome, easily passing into a condition of offensive rancidity.

While it has been economically of large significance, adding great wealth to the nation and playing no inconsiderable part in the prosperity of the United States, the creamery may be said to be most important of all in its freeing of the wives and daughters of the oldtime American farmers. I doubt if any activity which has sprung into life in the period of the New Earth can be mentioned which has had a more beneficent influence upon the women of the farm than the establishment of the creamery.

The first creamery in the United States appears to have been the one established in Orange county, New York, in 1861. Slowly the plan expanded, as the farmers saw the superiority of this method over the old one. It was then the custom to send the whole milk to the creamery, but in $\mathbf{1 8 7 5}$ the farmers began skimming the cream themselves and delivering it, in place of the whole milk. From this the step to the mechanical separation of cream from milk was natural. The magnitude 


\section{THE NEW EARTH}

of the dairy interests of the United States, now that they are assuming in the broader field of the New Earth the position to which they are entitled, is seen in the fact that, by the last census, there were over eighteen millions of dairy cows, ninety-four and six-tenths per cent of which were on farms or elsewhere enclosed.

Over seven billion gallons of milk were produced in the census year 1900, an average per year of four hundred and twenty-four gallons per cow. Somewhat over fifty per cent of all the milk produced came from the states of the north central division, Ohio, Indiana, Illinois, Michigan, Wisconsin, Minnesota, Iowa, North and South Dakota, Missouri, Kansas and Nebraska. During the same year nearly one billion, five hundred millions of pounds of butter were made, together with almost three hundred million pounds of cheese. It gives one an altogether enlarged view of the dairy industry of the United States under this new order of things, to note, in addition to all this, the fact that the value of the dairy interests of the United States is now considerably more than two billions of dollars, on which there is an 


\section{MODERN DAIRYING}

income of over five hundred millions of dollars annually.

The manufacture of cheese, too, on a scale at all commensurate with the possibilities of the country, dates from the beginning of the New Earth; though the first cheese factory was established, also, in New York, in Oneida county, in 1851. By the close of 1869, the number had increased to over one thousand in the United States. The manufacture of cheese was originally altogether confined to the farm; the results were not so satisfactory, however, as in the case of factory manufacture, so that out of the total of three hundred millions of pounds made in 1900, less than seventeen million pounds were made on the farms. Five states-New York, Wisconsin, Ohio, Pennsylvania and Michigan-made eighty and fourtenths per cent of all the cheese manufactured in the country.

The interest in cheese manufacture, and in all the related lines leading up to it, has been not less pronounced on the part of the men of practical science than their interest in the making of butter. 'The possibilities of scientific investigation are far greater in cheese than in 


\section{THE NEW EARTH}

butter. "The making of first-quality cheese," in the words of a bulletin from the New York Agricultural Experiment Station, "is undoubtedly the most interesting and most difficult operation in dairying. It is more interesting than butter-making, since the limits which include 'good butter' are narrow, while 'good cheese' may mean any one of a hundred products. By slight alteration in the process of manufacture, milk, a liquid with a mild sweet taste and characteristic, delicious aroma, may be transformed into cheeses of paste-like consistency, like Camembert, or the hard and stone-like Parmesan, may result in a product as mild-flavored as sweet cream or pungent enough to bite the tongue, as fragrant as perfect Cheddar or as repellant as Limberger. . . . The art of cheese-making has, possibly, touched its highest point in the hands of a few makers and at rare intervals, for occasionally a cheese is met with that the scorers pronounce perfect; but the time is evidently still to come when even a few cheese-makers can produce perfect cheese all of the time, or most makers some of the time. To explain this, we must admit that the science of cheese-making is not abreast with 


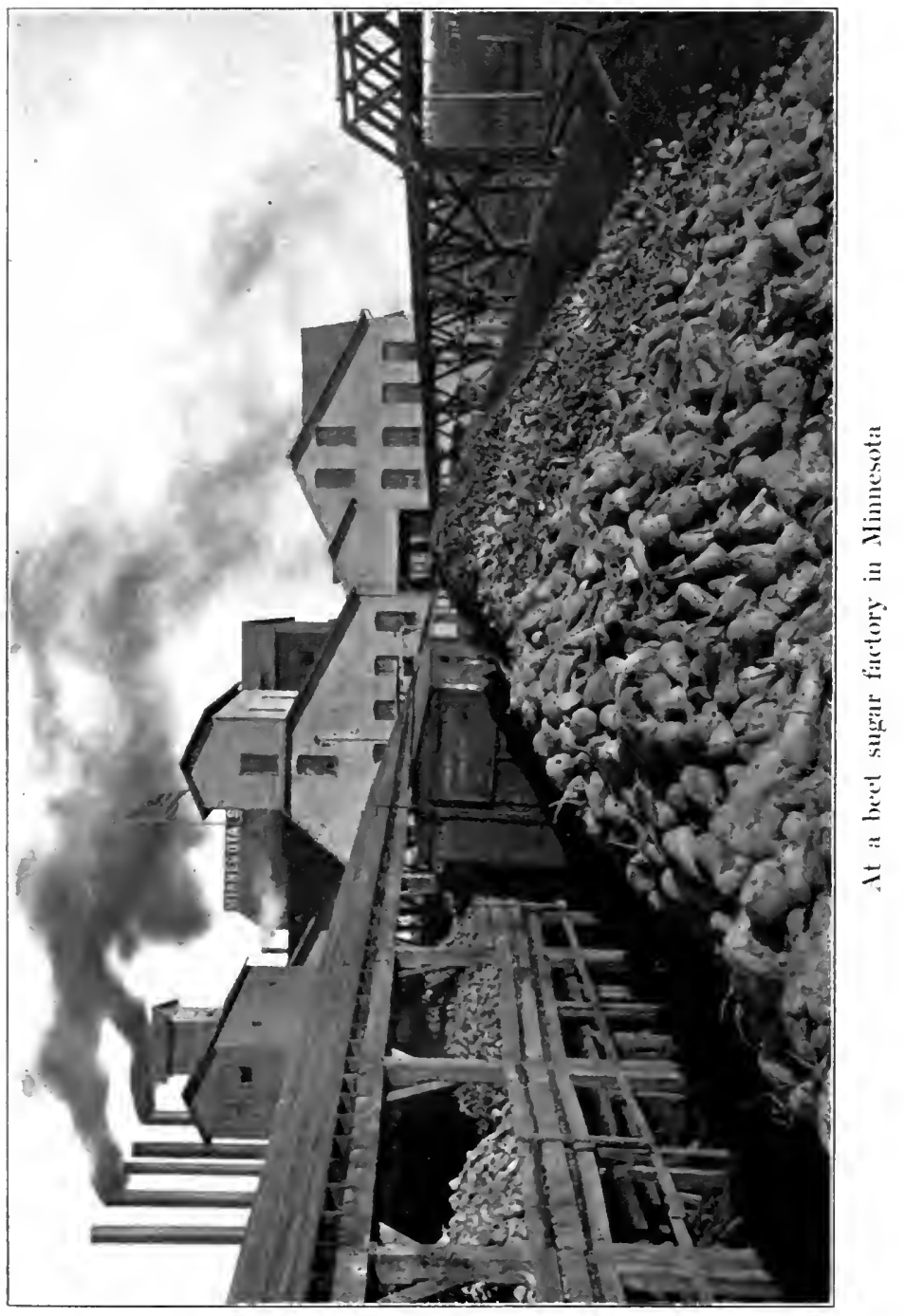



the art, for no maker can tell just why he frequently fails to produce the best of cheese even under most favorable conditions, and no student has yet been able to give the world a logical, correct account of the changes which take place during the history of a cheese, and of the causes which produce those changes. Until such an understanding of the underlying principles has been more perfectly attained, we can hope only for accidental or fortuitous advances in the art; when we have reached such an understanding, it will certainly be possible to raise the general level of cheese quality by teaching all makers better methods and closer control of conditions; and it may be possible to make a better cheese even than the one we now call perfect."

Wide-spread interest in modern methods of butter and cheese manufacture has been aroused and maintained by the establishment of farmers' dairy schools in connection with various agricultural colleges, where the farmers of a given dairy region may meet during the duller winter months for several weeks' study under the direction of trained experts. Many of the farmers have not had the advantages of 


\section{THE NEW EARTH}

college training, and the information imparted to them in these schools is of large practical value. The whole subject of dairying from a practical, as well as from a scientific standpoint, presents many features of peculiar interest. It is one of the most attractive, as well as, rightly conducted, one of the most remunerative of all the many departments of the New Earth. 


\section{CHAPTER XII}

\section{ANIMAL HUSBANDRY}

THERE is, perhaps, no other department 1 among the many branches of the New Earth which has been so beset with dangers, more open to the attacks of enemies, or which may be approached, for good or ill, from so many different avenues, as the one of which this chapter treats. Perhaps in no other line of modern life has there been displayed during this period so much selfishness and so great a determination on the part of unfair capital to take advantage of the necessities of the people; and yet those who provide the supply for the demand, however greatly misused they have been, have not allowed this selfishness to prevent them from advancing. So it happens that in the production of cattle, sheep, swine, horses, and the like, the progress made during the last third of a century has been among the significant factors in American farm life. The progress has been along two main lines, im207 
provement and enlargement,-improvement of native stock by breeding and selection and the constant testing of new strains of blood, to see whether or not they may be introduced from foreign countries with success; enlargement by constantly increasing the number of animals, to meet a demand which has increased more rapidly than the supply.

This picture rises in memory:

Overhead the blue sky, the air crisp with autumn frosts; a crowd of country people thronging the paddock at the county fair, all interest lost, for the moment, in the many fascinating features of the fair; far down the green a proud groom advancing leading an enormous Percheron stallion, a dark mottledgray, be-ribboned in many contests, while behind him come many other grooms, each at the head of a noble animal, each horse in turn seeming more worthy of applause than his predecessor. Out in front of the throng, watching warily every movement of the great animals, stands a white-haired, white-bearded old man, type of the line of southern gentlemen from whence he sprang, receiving, with fine pride in his eye, the tumultuous applause that 
comes up from the throats and hands of the thousands. It was an importation of Percherons from France, put on exhibition by the white-haired old southerner, a pioneer, I think perhaps it would be quite fair to say, the pioneer, in this line of importation; in any event, he was among the first to begin buying in person on French soil. It would be impossible to form any adequate estimate of the influence of this importer's stock upon the native stock of the region. These great draft-horses might be supplemented from time to time by other breeds having distinctive excellencies, but the original blood introduced left a powerful impress. The initial work was all-important, too, in educating the farmer to the possibilities of strengthening his own stock.

And so it has gone all along the lines of animal life in the years of the New Earth,from the lordliest stallion to the most vociferous cockerel that ever proclaimed the blueness of his blood in the midst of an admiring harem,- - a determined effort to improve the domestic animal life of America. So widespread has been the interest during this period, and so keen has been the rivalry, that no end of 
money has been squandered on fancy stock by those whose eyes were blind to everything but the glories of the stud-book and who would content themselves with any sort of a looking brute if only there were an immaculate pedigree behind; while, indeed, there has been no small danger through the introduction of animals over-bred or in-bred to, and beyond, the danger point of disease. Yet, on the whole, the process of toning up what may be called the native stock, has had an influence incalculably powerful upon animal life in the United States.

The greater portion of this so-called native stock dates back for its origin, in the main, either to the Spanish or the English. The first neat cattle came with Columbus, who brought them to the West Indies, from which they spread to Mexico about the year 1525, and thence upward to Spanish territory and to what is now California, New Mexico, Arizona and Texas. Horses came with Columbus, too, and they were put to good service by DeSoto in his western journeyings. Doubtless they were the progenitors of the wild horses of the Southwest, as were his cattle the progenitors of 


\section{ANIMAL HUSBANDRY}

the Texas cattle. Sheep were a part of the Spanish bequest to America also. 'The mission fathers, who made their way north from Mexico to the present state of California, after long hardships, not only rejoiced in vineyards and orchards, but they grew rich upon their flocks, at one time having over a million sheep at their missions, aside from those which belonged upon the ranches.

The English, later, were earnest in their endeavors to increase the animal population of the new world, bringing in cattle to Massachusetts in 1624, while Holland sent cattle to New York in 1627, and Denmark sent them to New Hampshire in 1631. Among the early animals in these states were Devons, Shorthorns, Herefords, Galloways and Alderneys.

Improvement in almost every line of animal life progressed slowly. It seemed to need that wide-spread general revival of interest in farm life which has come in, with the New Earth, to stimulate and broaden animal husbandry. In the earlier years much of the breeding was for show alone. Naturally, with the rapid development of the western country came greater demands for service stock, so that 


\section{THE NEW EARTH}

horses on farms, for example, from 1850 to 1900 , increased very nearly 300 per cent. Notwithstanding the fear of many that the horse would give way before the bicycle, the motorcycle and the automobile, the horses in the United States number at present more than twenty-one millions, while their value by the last census was over a billion dollars. On the Chicago market, horses, from 1899 to 1904, increased in value from ten to thirty-five dollars per head.

It is of interest to note that the national government, under congressional appropriation, has begun the work of establishing an American carriage-horse. A series of breeding experiments is now under way, whose object is to produce an entirely new horse, so to speak,--one which shall be peculiarly adaptable to the needs of Americans. It is intended that this horse shall be the foundation of a race which shall stand entirely independent of foreign breeds.

In every department of animal husbandry, efforts are being put forth to strengthen the older types. It is practically in the period of the New Earth that swine-breeding has reached 



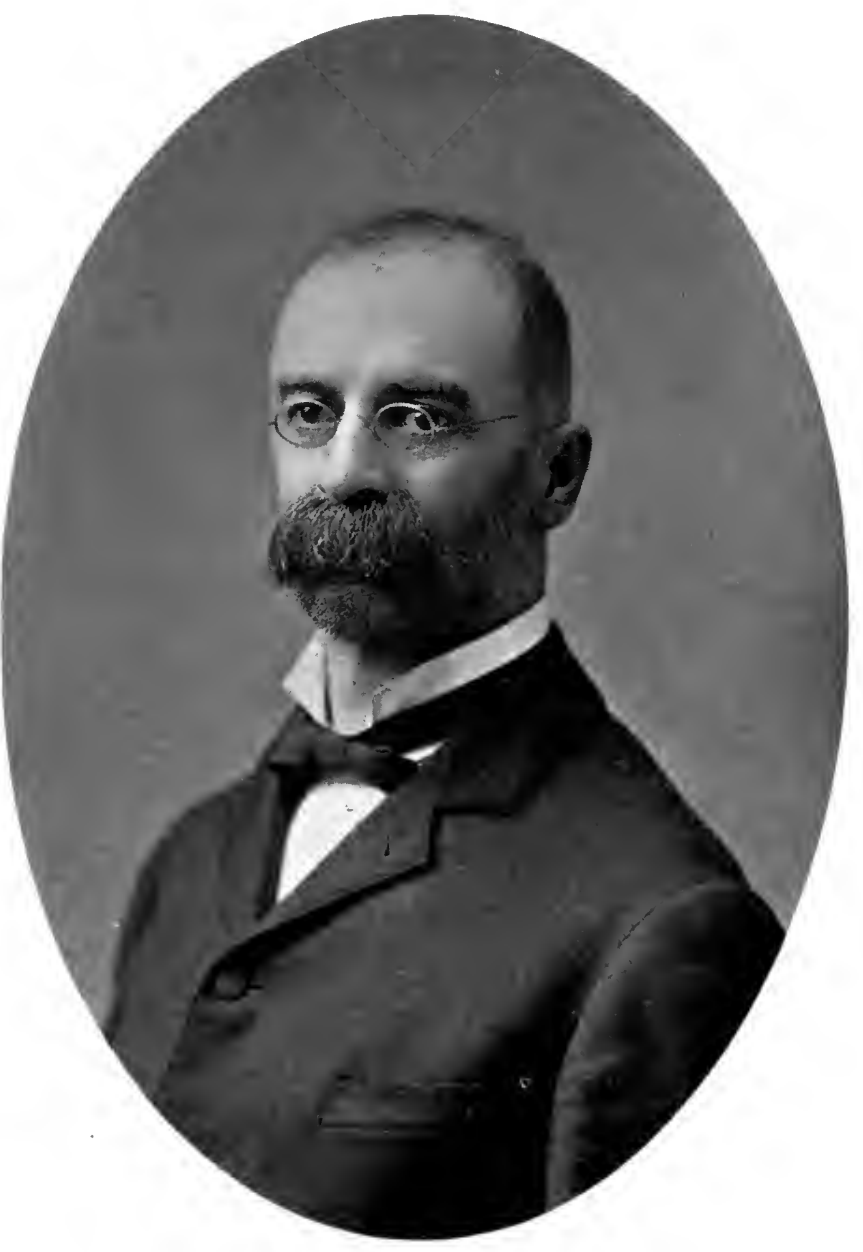

Dr. S. M. Babcock, inventor of the Babcock test 
anything like important results. The years of the first registrations of the different swine breeders' associations are as follows: American Berkshire, 1875; Standard Poland-China, 1877; Central Poland-China, 1879; American Chester White, 1884; American Essex, 1887; American Duroc-Jersey, 1890.

But, while great improvement has been made through the introduction of new blood, perhaps the greatest improvement in the life of domestic animals in America has been that effected through what may be termed animal culture. This includes not only a strengthening of the stock through the most careful selection in breeding, so that new combinations and crosses may be made to produce better cattle, better sheep, better poultry than any that preceded, but the most painstaking and systematic experiments in feeding. Feeding and breeding lie at the base of the progress of animal husbandry in the period of the New Earth. This feeding has been two-fold in object: to produce better animals, stronger, more profitable on the block or on the farm, but to do it at a minimum of cost. Waste, most foolish and extravagant waste, has been 
one of the curses of farming in America. It is one of the objects of these feeding experiments to put a stop to this waste by showing that better results can be reached under new methods by a far less expenditure of money. I know of no way in which the practical value of modern science,-I had almost said modern sensible science, for there is a so-called science which busies itself with things which are only mildly mystical, - can better be shown than in these great animal-feeding tests which have been undertaken in the latter part of this past generation. Take, for example, as an illustration of the scope of the work, the tests under way by the national government in the feeding of horses. Here it has been demonstrated, after exhaustive tests, precisely how much of a given food is assimilated by a horse, how much is wasted, how to combine rations so that this waste may be reduced to a minimum and the horse be fed in the most economical manner. It is shown that only thirty-four per cent of the food consumed by a horse is converted into energy or working power, while the remaining sixty-six per cent is devoted to the running of the horse, so to speak,-to keeping 
up its mechanism. So complete are the tests that it is demonstrated that twenty per cent of the energizing value of the oats fed to a horse is used up in chewing and digestion, while experiments show that by keeping a horse in a stall too cold for him, two pounds of oats per day are necessary to supply the waste caused by the cold. It is shown, too, that while the horse makes use of only thirty-four per cent of its food for working purposes, it is yet much more economical than the steam engine, which, at the best, turns less than twenty per cent of its fuel, or food, into energy. In Paris it is shown that the largest cab company in the city saves two hundred thousand dollars a year by taking advantage of the facts developed in the tests of food values for horses. One important feature is the substitution of corn for oats, the latter proving an excellent food for producing energy.

Years are being spent in some of the experiment stations of the United States upon problems of animal-feeding, with results that are proving of large economic value. How to provide the most satisfactory ration at the lowest possible cost, and so avoid the well-nigh crimi- 
nal waste of former years, is one problem; how to produce a maximum of meat, butter, eggs, or milk at a minimum of cost, is another. It would have been all Greek to a farmer of the Old Earth to tell him of a dual-purpose cow,one that would produce milk and butter profitably for home consumption and at the same time be the mother of calves which, if desired, would make marketable beef. It would have been quite outside his line of vision, too,- - a study recently followed for some years, and successfully, in one of the agricultural colleges,to educate, so to speak, the sheep to give birth to their lambs earlier in the season in order to give the farmer early spring lambs to put upon the city market at a higher rate of profit.

It would require volumes to describe the many different ways in which practical scientific men are now at work upon the problem of producing better meat products. 'Take an illustration: In 'Tennessee the growing of alfalfa has come into favor, as it has in other states, as a desirable food for stock. 'The State Experiment Station of 'Tennessee, after the introduction of alfalfa began, set out to determine the real value of the new food - was it any better 
than the old and, if better, could it be produced as economically? It was shown, after exhaustive experiments, that alfalfa, cow-peas, and other similar leguminous plants could be substituted for other and more expensive concentrated foods without loss in product and at reduced expense. Careful and systematic feeding tests were carried on and accurate records kept. It was shown that, with alfalfa hay at $\$ 10$ a ton and wheat bran at $\$ 20$ a ton, the saving effected by substituting alfalfa for wheat bran would be $\$ 2.80$ for every one hundred pounds of butter made and 19.8 cents for every one hundred pounds of milk. It was also shown, among other things, that a ton of alfalfa or pea hay could be produced at a cost of from $\$ 3$ to $\$ 5$, while wheat bran would cost from $\$ 20$ to $\$ 25$ per ton.

In a number of states, the experiment stations have conducted experiments in the feeding of beet molasses and beet pulp to sheep and steers, materials hitherto considered as waste. The beet pulp has proven an excellent food and much cheaper than the feed usually given. At the Utah Station one hundred pounds' increase in a test with a lot of steers, 
on a full ration of grain, cost $\$ 4.93$; the same increase in weight on another lot on a full ration of corn, grain and pulp, cost $\$ 3.98$, nearly a dollar less. Thousands of sheep and steers have been fed at one sugar factory in Utah on the pulp, which provided a profitable food.

In Illinois, where nearly or quite four thousand farmers are extensively engaged in beef production, from 200,000 to 300,000 cattle are marketed each year. It is shown that by taking advantage of the more improved methods of feeding stock, based upon a scientific knowledge of foods and food values, an addition in value of considerably over one dollar per head can be effected, resulting in a net annual gain in this state alone of over two million five hundred thousand dollars. As an illustration of the thoroughness of the investigations carried on in this line under the stimulus of the activities of the New Earth, it may be noted that the Illinois Station undertook to find out just what the farmers were doing in this and adjoining states in the way of producing beef. A list of one hundred questions, covering every department of animal husbandry as it applies 
to the farm, was sent out to six thousand cattle feeders. The replies received, when tabulated, showed that they covered experiences of over one thousand one hundred men with a combined experience in cattle-raising of more than fourteen thousand years, during which time they had fed nearly a million and a half cattle. Two significant conclusions were drawn from the investigation,- that the farmers realized the need of better blood in their herds, and the necessity for more intelligent use of feeds.

The Storrs Experiment Station in Connecticut has taken up the subject of the amount of protein needed for the rations of a dairy cow. $V$ arious dairy herds in the state were visited by the representatives of the station, and the dairymen worked in connection with the station in keeping a record of the feed used. A certain ration was recommended by the station and, in so far as possible, this ration was used in comparison with the rations that had been in common use. The results reached showed that rations containing more protein than those usually fed are better, while the value of the manure obtained from the more nitrogenous 
ration is noted as an important feature. In comparing the original, or regular dairy ration with the recommended ration of the station, it was shown that the average cow, instead of shrinking in her milk during the period, as she normally would have done on a uniform ration, gained appreciably on the recommended ration; the increase in milk flow amounting to $\mathbf{1 . 2 9}$ cents per cow per day, which, with the saving in cost of food and the increased value of the manure, made a net saving of 2.02 cents as a result of the substitution of the recommended ration of more protein. A series of tests were made at the Minnesota Station, to determine whether or not steers could be raised on the farm in competition with those raised on the great cattle ranges of the farther west. Calves were selected and fed suitable farm products, such as any farmer could grow, and the management included no details that the average farmer could not follow. The results were very satisfactory, showing that, while the initial cost of producing steers on the range was much less, beef could be grown profitably under normal farm conditions; that the quality was of the very best; while it was clearly shown 


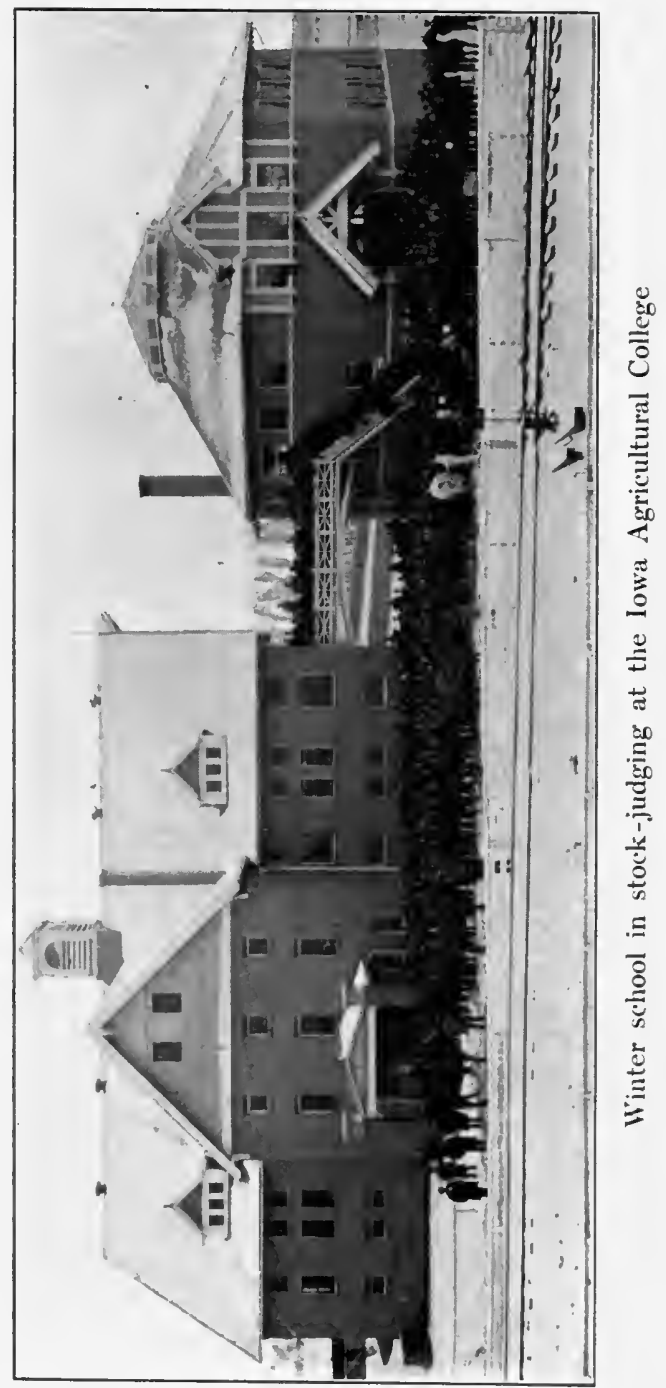





\section{ANIMAL HUSBANDRY}

that the farmer could get better values for his produce thus fed to the cattle than by selling the produce on the market.

Other stations pay close attention to the values of commercial feeding stuffs, for which, sometimes, extravagant claims are made. The Vermont Station, for example, made investigation during 1905 into one hundred and fifty kinds of these stock foods, the by-products of oil mills, distilleries, glucose and breakfastfood factories. These were tested chiefly for protein. While some samples were wholly satisfactory, many were found short in protein. "The gluten goods," says a bulletin from the Vermont Station, "particularly the feeds, are consistent in their failures to meet guaranties. 'The shortage in the protein in the distillers' dried grains is getting to be perennial. A large proportion of the oat and corn feeds, the output of the oatmeal mills or of mixers, failed to meet the claims made for them." The bulletin makes note of the fact, in considering one of the lines of feeds, that there is one redeeming feature,-the poorer the feeds are the better, since such a condition will tend, in the long run, to lessen their sales. 


\section{THE NEW EARTH}

The wide diversity in interests in animal husbandry will soon become clear to any one who attempts a study of the subject. The work of the practical scientists has advanced upon so many lines, in the development of the industry that volumes would be required to describe them all. Simply for illustration, what, it may be asked, would a farmer of the Old Earth have thought had he learned that some public institution of the state had devoted time and money to the investigation of the subject of protecting cows from flies, and had followed up this investigation with an additional expenditure of money to put the results of the investigation in print and issue it broadcast over the state? Yet out of this subject the Storrs Connecticut Station has developed some thoroughly practical material. In states where vicious flies are abundant, it had been believed that there was a falling off in milk during the "fly season," due to the worrying of the cows by the pests. Some one started the manufacture of fly preventives, and a long list of sure-cures followed, The college herd was divided into two sections, which were alternately treated with one of the fly- 


\section{ANIMAL HUSBANDRY}

removers, which, so the manufacturers claimed, would save fourteen dollars in cash per cow during the fly season, to say nothing of the comfort of the cow and the milker. The preventive was applied with a spray. The result of the test showed that there was no gain in milk production, no gain in butter-fat, while the hair of the cows became more or less gummy from the application, and the milk, on a number of occasions, took from the preparation a peculiar odor. The investigations showed that the annoyance to dairy cows by flies has been overestimated, and that the benefits from the use of proprietary flyremovers have been exaggerated. In another similar test made at the Wisconsin Station, one-half of the herd was kept in stable during the day while the fly season was in progress, the other half of the herd being left exposed to the flies in the open. The results of the test showed that the cows protected from flies by being stabled ate in four weeks eight hundred and thirty-five pounds more of green feed and lost one hundred and thirty-three more pounds of flesh than those in the open exposed to the flies; while, still more signifi- 


\section{THE NEW EARTH}

cant, those confined decreased sixteen and three-tenths pounds in milk flow and one and thirty-five-hundredths pounds in butter-fat production.

One more illustration, as showing the remarkable diversity of the investigations in these days of the New Earth, must suffice. Certain portions of California, notably within a radius of a hundred miles from San Francisco, seem peculiarly adapted to the production of eggs and chickens, particularly the former. Near the town of Petaluma, the center of what is said to be the largest poultry region in the world, the state has established a poultry experiment station, where experts study the diseases of poultry, find out the value of poultry foods for the production of flesh, fat, eggs and feathers, investigate questions of sanitation, and, in general, give scientific and practical aid to the industry. One of the first bulletins to be issued as a result of the investigations deals with tuberculosis in fowls. 'This is a serious matter in Europe, and, though not so prevalent in the United States, the disease yet exists extensively among many large poultry ranches. One rancher lost about two 


\section{ANIMAL HUSBANDRY}

hundred and fifty fowls out of a flock of fourteen hundred in a single year. The bulletin issued contains a full and clear description of the symptoms of the disease, the diseased conditions to look for when the fowl is killed, with illustrations of diseased parts. Ways of infection are also noted. It is shown also that no known remedy exists for tuberculosis in fowls,-killing as soon as found affected is the only alternative. So far, there is no means of detecting the existence of the disease until it has progressed sufficiently to produce lameness, or emaciation. The tuberculin test used in detecting the disease in cattle does not give positive results in fowl. The bulletin says, upon the important question of danger to man from tuberculous fowl:

"Tuberculosis in man is not noticeably prevalent in the community where most cases of the disease in fowls have been found, for it is not frequented by consumptives in search of favorable climatic conditions. 'The possibility of the transmission of tuberculosis from poultry to man is a matter concerning which it is exceedingly difficult to collect evidence. The fact that chickens, when eaten, are always 


\section{THE NEW EARTH}

well cooked, indicates that there is practically no danger from that source. It has not been proven that tuberculosis is transmitted through the egg, and furthermore, most eggs are well cooked when served. It does not appear, therefore, that tuberculosis in fowls is a matter that very intimately concerns public health."

It would be idle to attempt estimates of the future growth of animal husbandry in the United States. That it has now reached large proportions and stands among the great factors of national wealth may be seen from the fact that the total value of the domestic animals of the United States at the last census was very nearly three billions of dollars. Of this vast sum distribution is as follows: Neat cattle, 49.5 per cent; horses, 30.1 per cent; mules, 6.6 per cent; sheep, 5.7 per cent; swine, 7.8 per cent; asses and burros, .2 per cent; goats, .1 per cent. It is interesting to note that this last relatively small per cent represents nearly two million goats, valued at over three millions of dollars. Nearly all the live stock is on farms and ranges, though 6.7 per cent of the value of all live stock, or $\$ 214,658,873$, applies to stock not upon farms or ranges. 
Recent statistics place the number of swine in the nations which are the chief producers of that animal as follows: The United States, 67,000,000; Germany, 17,000,000; Russia, 11,000,000; Hungary, 7,000,000 ; Canada, 3,000,000, Spain, 2,000,000 ; Roumania, 2,000,000; Poland, Belgium, Denmark, the Netherlands and Australasia, each 1,000,000, the United States thus having much the larger proportion of the world's supply. All but fourhundredths of a per cent of the sheep of the United States are upon farms and ranges. Since the period of the New Earth the average production of wool per sheep in the United States has increased 140 per cent, while wool product has increased 300 per cent. During the same period sheep have increased in numbers in the United States 67 per cent, which, taken in connection with the situation abroad, and with the possibilities for the extension of sheep-raising in this country, forms an interesting situation. 'Throughout foreign countries there has been, curiously enough, a falling off in sheep production in the same period. A recent United States consular report shows that the flocks of the world outside of the 
United States have declined at least ninetythree millions since 1873. 'The report, appearing in September, 1905, written by Consul Williams, of Cardiff, Wales, making note of the fact that this is the American farmer's opportunity, says, incidentally, as to the causes of the decline:

"'The world is eating up its sheep. Its flocks have been declining for three decades, and that decline has become perceptible in so many countries that it is regarded as the most remarkable agricultural movement of our times. A number of independent causes have coöperated to bring about this result. 'The first to be noted is the modern method of studying Hebrew history and literature. This has brought to light the fact of the preponderance of mutton in the meat diet of the Hebrews from the earliest times, a preponderance that accounts, in part, for the character of their civilization, and their persistence as a race. The dread of tuberculosis and pleuro-pneumonia in some countries, and of trichina in others, has led to the substitution of mutton for other meats by several classes, especially those influenced by the lurid accounts in the 



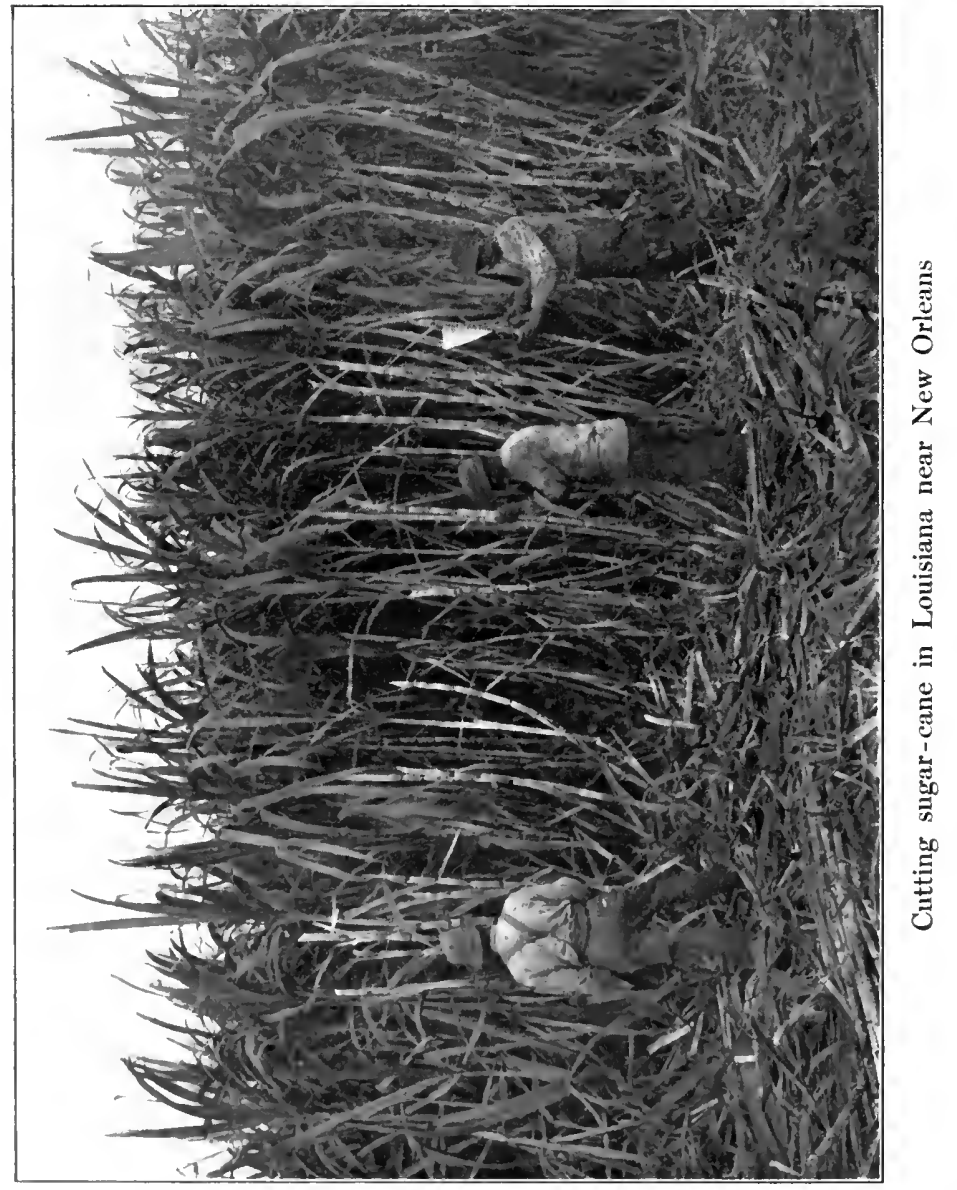


sensational press. The high price of beef in recent years has forced many others to make a like substitution. But the principal cause of the decline of sheep has been the movement of the agricultural population to the industrial centers in the towns and cities. This class, with an already acquired taste for mutton, is able to gratify that liking to a greater degree in the town than in the country, both on account of the better opportunity offered by the open market, and the increase of its purchasing capacity by the higher wages paid in the towns."

While from time to time, for one reason or another, objections are raised on the part of foreign countries against American meats, the fact remains that the overcrowded nations of Europe must depend upon outside sources - largely, perhaps chiefly, upon the United States-for flesh foods. In Germany, during the summer of 1905, under a meat inspection law of unusual stringency aimed at exclusion, the prices of meats rapidly rose, and the supply decreased until the matter became of greater national significance than the alleged dangers from the foreign meats. 'The whole- 


\section{THE NEW EARTH}

sale price of live hogs advanced under the new law from $\$ 21.42$ per two hundred and twenty pounds in 1900 to $\$ 30.94$ in 1905 , or more than fourteen cents per pound. Steers advanced at a still heavier rate. In Berlin fresh pork advanced to twenty-four cents per pound, veal to thirty-five cents, mutton to twentyeight and one-half cents, beefsteaks and roasts to thirty-five and one-half cents, putting meats wholly outside the reach of the working people. Many serious complications followed, not the least of them being the injury to dealers, over thirty meat shops in the city of Frankfort-on-the-Main alone having been closed or announced as about to be closed through the destruction of their trade by the scarcity and high prices of meats.

Russia in Europe in 1905 had only 24,000,000 head of cattle and 35,000,000 sheep for a population of over $90,000,000$, and no other country in Europe had so large a number. Great Britain and Ireland had only 11,000,000 head of cattle, 6,000,000 hogs and 34,000,000 sheep for a population of nearly $43,000,000$. In the United States, during the years when there has been a constant decrease in Europe, 


\section{ANIMAL HUSBANDRY}

there has been a marked increase. In 1850, the value of all the live stock in the United States was a little over five hundred millions of dollars. 'The increase in value from 1850 to 1860 was 100.2 per cent; from 1860 to 1870 , 12.9 per cent; 1870 to $1880,28.2$ per cent; 1880 to $1890,46.4$ per cent; 1890 to $1900,29.1$ per cent. While the value of the live stock of the United States has now risen to nearly three billions of dollars, and while, with a rapidly increasing population, the home demand must remain large, the opportunity for American meats abroad is great and must become larger year by year. With increased demand must come increased prices, and the vital question now before the producer of these supplies in the United States is, how he may receive his fair share. Rapidly growing up in these years of the New Earth has bcen a conscienceless monopoly in meat products in America. Some method of controlling this monopoly and counteracting its brutal rapacity must speedily be devised, if the animal-husbandry interests of the United States are to escape a danger imminent and of colossal magnitude. 


\section{CHAP'TER XIII}

RECLAIMING THE EARTH

\section{A LIMITLESS sweep of sand; a hot blue A sky, with the merciless sun traveling} through it day by day, with never a cloud to break the force of his rays; here and there a caravan of camels toiling steadily along or grouped by the side of palms in a beautiful green oasis; out on the wide reaches now and then a strange mirage wherein were houses, and ships, and fountains, and fair streams flowing between green banks;--something like all this passed in procession before the mind of a boy as he looked at the map in the geography he was studying, and saw, outlined in dots, a wide stretch of country marked "Great American Desert." All the boy had read or heard of the deserts of Arabia and Africa he pictured here in his own country, and wondered would the day ever come when he would be able to take the long journey across this mighty desert on the back of a rocking camel. 
One day, when the boy had become a man, he did make the journey. Hour by hour, indeed, day by day, he traveled across this mighty waste,- not on the rocking camel, but behind a powerful engine speeding westward by night and by day through glorious sunrises and sunsets prodigal in their wealth of lavender and orange and amethyst and ruby, past distant mountains splashed with yellow and red and purple with here and there a lofty peak, white with eternal snows. But below was naught but sand, the white heaped-up sand of the Great American Desert of boyhood, drifted here and there into huge dunes, etched up their dazzling sides in serried layers where the winds had blown as they blow the snows of winter, here and there spread out like some vast palace floor, white and dazzling, to the line where the blue dome of the palace shuts down unpillared to the earth. The sands were there and the oases, too, but not the camels, nor the caravans. The oases, indeed; for one day there appeared in the far west a faint green line stretching, in the ghostly twilight, like an emerald thread across the purple sky, at the base of a huge mountain towering where the snows rest. Lit- 


\section{THE NEW EAR'TH}

tle by little the train drew nearer, and when an hour had passed it cut through the green thread, the sands slipped backward into the night, and lo, a miracle! For suddenly, mile upon mile stretched away noble green sweeps of orange and lemon, pomelo and lime, olive and fig, and, further upward along the mountain side, grapes, ripening in the mellow sunshine still aglow on the upper mountain slopes. There were lovely homes, embowered in roses and adorned with stately palms; there were little towns where penury never stalks, and further on, thriving beautiful cities throbbing with American life.

It was a noble prospect. When the New Earth began it was a sand-strewn waste, part and parcel of the Great American Desert. It was the miracle of the Spirit of the Water. It has taken but a few years to make these oases, and, though they have proven beautiful to the eye and fattening to the purse, they have merely dotted the desert, and millions upon millions of arid acres yet remain. So man has begun to sponge off the Great American Desert from the map. It is now, since the New Earth began, a movement in full swing,- the 
most important, in some ways, among all the varied activities of this period.

I passed along a palm-bordered road, one day, where but a few years before sand and stunted chaparral and the dreaded cactus marked the region as fit only for the seat and home of Desolation. On one side of the road, far toward the blue foothills, spread the glossy green tops of the greatest lemon orchard in the world, full thirty thousand acres, reclaimed by the water impounded in the near-by mountains or pumped here and there from the rivers that run upside down, those curious Califormia rivers flowing through the sands below the sight of the eye. Beyond the mountains of Mexico in the distance stretched the blue Pacific, and in the far offing you might see white battleships riding lazily at anchor. It was a rare scene, full of placid beauty, suggestive of riches and content.

On the other side of the road the trees were dead, their bare branches stretched toward the great hot sun, their lifeless roots held fast in the vise-like grip of the deep-baked soil. Acre after acre stretched away toward the circling mountains to the north, unrelieved in their 


\section{THE NEW EARTH}

barrenness save here and there where appeared a leafless tree still bearing some show of yellow fruit, a tree not quite dead, and struggling with all a plant's silent heroism to ward off its doom.

One side of the road had had water and still used it, year following year, and it was a garden; the other side, sixty feet away, had had water, had profited by it till its trees were large and thrifty, had then been abandoned by some thriftless owner; it was traveling at steady speed back to the desert.

No human being is prepared to say that he knows the preciousness of water until he knows the desert. It is more than a precious thing, it is a great elemental force second to no other in the universe; indeed, where shall its equal be found for wideness of scope and influence?

But see how the period of the New Earth is transforming those waste places! Scarce a generation ago, the dotted lines of the Great American Desert encircling the haunt of death; today, divided into rich states, while the national government, realizing that the only thing needful to make this desert blos- 


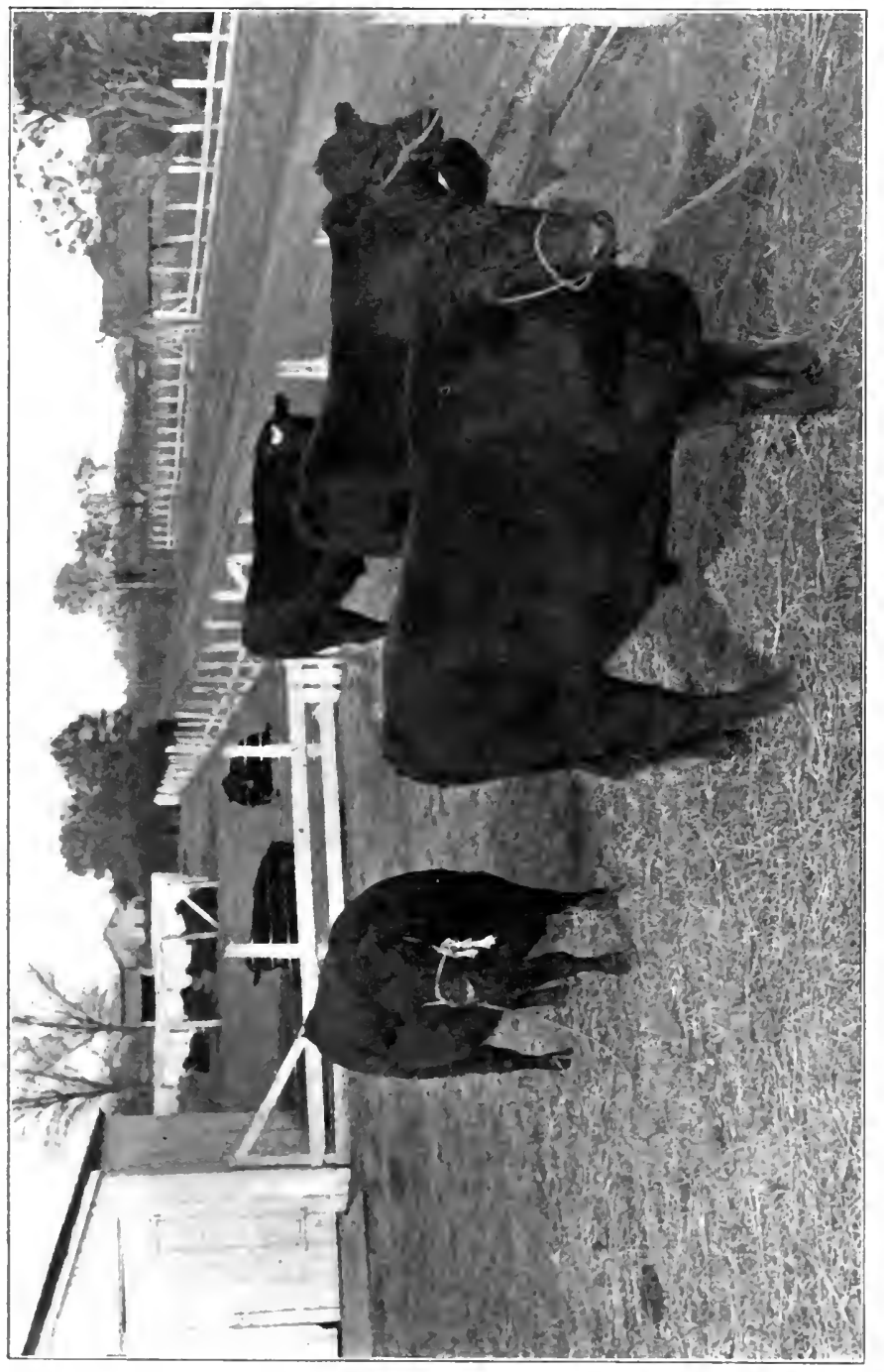

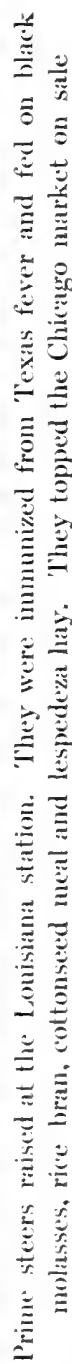



som and bear was to take the waters that for uncounted centuries, coming down from their homes in the white mountains, had gone wastefully by these arid lands, harness them, and send them out to the service of man, has begun the greatest reclamation project of modern days,-in its scope the greatest perhaps in the history of the world.

In considering somewhat more in detailthough, of necessity, in condensed detail-the factors at work for the reclaiming of the arid lands of America during this New Earth period, this project of the national government. may first be referred to,-one of four distinct reclamation features which, all told, promise to work the mightiest transformation,- - surely the words are not overdrawn-ever accomplished in this line.

'There are, in round numbers, fifty millions of acres of arid land which come directly with-in the scope of this reclamation act of 1902. It is the purpose of the government, under the provisions of this act, to restore this vast empire to fertility. By the exercise of sound common sense, this national reclamation is in no possible sense paternal. Paternalism, at the 


\section{THE NEW EARTH}

best, among childish peoples is only a sorry makeshift tending toward flaccid mental muscles; while paternalism in a free republic like our own is a national sin. These fifty millions of acres of arid land will be reclaimed by means of money derived from the sale of the government lands in the thirteen states and three territories in which the irrigation will be introduced-Arizona, California, Colorado, Idaho, Kansas, Montana, Nebraska, Nevada, New Mexico, North Dakota, Oklahoma, Oregon, South Dakota, Utah, Washington, Wyoming. To begin with, there was a fund already accumulated of thirty million dollars, soon to reach fifty million dollars. The government is taking this money, finding out just where it may be spent to do the most good to the largest number of people, is constructing reservoirs and digging canals and distributing the water over the desert places. It is believed that by the time the fifty million dollars is expended this Great American Desert will afford homes for fully five hundred thousand people,-homes where there will be ever at hand in soil and climate and water the means for a comfortable living. Still further to avoid 
paternalism, the settlers upon these landsdivided into farms of not less than forty nor more than one hundred and sixty acres, and not more than one farm to one person-will be required to pay back to the government in proportion to the benefit they receive until the total initial cost of the various irrigation projects has been met. The money will then be used over again for further reclamation and allied purposes. The amount of money each settler pays is small,-twenty dollars, in ten annual instalments. 'The settler must be a settler indeed, an actual bona fide resident upon the land. Only by enforcing this provision with an iron hand can this great project become what it should become, the most important agrarian enterprise of modern days. The situation stood as follows in the autumn of the year 1905:

\section{Projects now Under Constrliction}

State Projects $\begin{gathered}\text { Amonnt set aside } \\ \text { for beginning Acres } \\ \text { construction irrigable }\end{gathered}$

A rizona .................Salt River ........\$3,600,000 180,000

Colorado ................ Uncompahgre...... 2,500,000 125,000

Idaho .............................. 1,300,000 60,000

Nebraska and Wyoming..... North Platte...... 3,500,000 100,000

Nevada ................Truckee-Carson..... 2,740,000 100,000

New Mexico............... Hondo.......... 280,000 10,000

South Dakota ..............Belle Fourche ...... 2,100,000 80,000

Wyoming ........................... 2,250,0 2500 125,000 


\section{THE NEW EARTH}

Projects for Which Bids Have Been Received

State Projects $\begin{gathered}\text { Amount set aside } \\ \text { for beginning } \\ \text { construction Arrigable }\end{gathered}$

California and Arizona ...... Yuma ............\$3, $000,000 \quad 85,000$

Montana ................... Huntley ............. $900,000 \quad 35,000$

Montana and North Dakota..Ft. Buford........ 1,800,000 60,000

Projects Approved by the Secretary of the Interior

Oregon and California....... Klamath Falls .....\$1,000,000 236,000

Oregon..............................2,250,000 100,000

Montana .......................... $1,000,000 \quad 200,000$

North Dakota .............Bismarck ......... 15,000

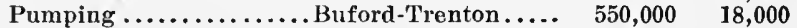

Washington ................Palouse (postponed). 2,800,000 80,000

Idaho ......................... $1,300,000 \quad 250,000$

The amount of land to be irrigated in these initial enterprises is one million, eight hundred and fifty-nine acres. It is estimated that the reclamation of this section of the arid West will increase land values nearly ninety millions of dollars, with an annual income from the lands irrigated amounting to nearly thirty millions of dollars.

The possibilities of this, one of the commanding acts of agriculture in the era of the New Earth, can not be estimated. As the years pass, the occupants of the new region will become more intensive in their farm life, and thus there will be provision for other and still other thousands of settlers, all of them, even unto the millions, sustained and 
protected by the mighty Spirit of the Water, the conqueror of the Great American Desert.

On June 17, 1905, the third anniversary of the passing of the reclamation act, the waters of the Truckee and Carson rivers in western Nevada were turned into the huge canal which had been constructed in that state, the initial performance under the reclamation act; national irrigation in America had begun. 'This unit, as it is called, of the entire system of all these various states will irrigate over three hundred and fifty thousand acres of land,desert land through uncounted centuries. Nine millions of dollars will be spent before this unit is finished. There will be ninety miles of main canals and twelve hundred miles of lateral canals and ditches. 'The opening was an event of no mean importance. So the work of reclamation goes forward by the national government, the development of each unit in each state, each project for the utilizing of so many more thousands of acres of land, being hailed by the residents of each commonwealth as a new inspiration for progress.

Irrigation is no new thing under the sun. Thousands of years before the dawn of the 


\section{THE NEW EARTH}

Christian era it was in practice in Egypt, primitive, as in large measure it yet remains there to this day, but yet of incalculable value to the regions that border the Nile. Irrigators in America, as a government report sets forth after an exhaustive study of the subject in Egypt, have little to learn from that country. A country still using a crooked stick for a plow will hardly serve as a model. The feasibility of irrigation, its possibilities, its rapid and permanent advancement of land values, its influence in providing homes and sustenance for steadily increasing populations,-all this was long ago established on the banks of Father Nile, while the great Assuan dam, far up the Nile, constructed as the result of the investigations of the technical commission appointed in 1894, has shown conclusively the importance of a far wider utilization of the waters of this great African river. 'The initial cost of this Egyptian dam was about the same as will be the cost of the completed 'TruckeeCarson unit, while the added increase in the wealth of the people of Egypt will be at least eleven millions of dollars each year.

When all these dams and canals in all these 
states are constructed, when the raising of herds, of forests, of grains and fruits and vegetables is under way, when these fifty millions of acres of desert land are reclaimed for the use of man, who shall be able to estimate the consequent increase in material wealth? Irrigation is not a dream. It is an unanswerable argument, - unanswerable, because it has been answered century by century since the beginning of man's reign upon the earth. The only wonder is that national irrigation was not sooner commenced in America.

Another interesting development of the period of the New Earth, in the reclamation of arid soil, has been brought forth in the state of California, which, by reason of its climate, the natural richness of its arid soils, and its general adaptability, is, perhaps, the most favored state for the prosecution of the work of reclamation. With the period of the New Earth began that long series of soil experiments under Prof. E. W. Hilgard, director of the station, which have been of such remarkable service to this state. While welcoming every effort put forth for irrigation, the soil investigations had for their immediate aim the prov- 


\section{THE NEW EARTH}

ing of the fact that cultivation, and, with cultivation, a knowledge of the structure and needs of the soil, was not less important than irrigation. All the water in the world will do but little good if allowed to run to waste, or if it is not used with intelligence. Professor Hilgard, for example, took up the study of a certain desert section. He made the most searching analyses of the soil at all depths, determining precisely its constituents and its needs. In the midst of the study of these sections, he arrived at results that have had an important bearing on the cultivation of fruits, and have added great wealth to his state. For example, he proved that the soil in the arid regions was very deep, with an absence of subsoils, showing that cultivation might reach to any feasible depth, and thus crops would be able to root deep and withstand drought. Again, a system of preliminary tests developed many facts both as to the chemical and physical character of the soil itself, and as to the soil in the main, showing thus what crops were best fitted to given soils before the crops or orchards were planted. Some five hundred soils are thus analyzed by this station free of all cost every 



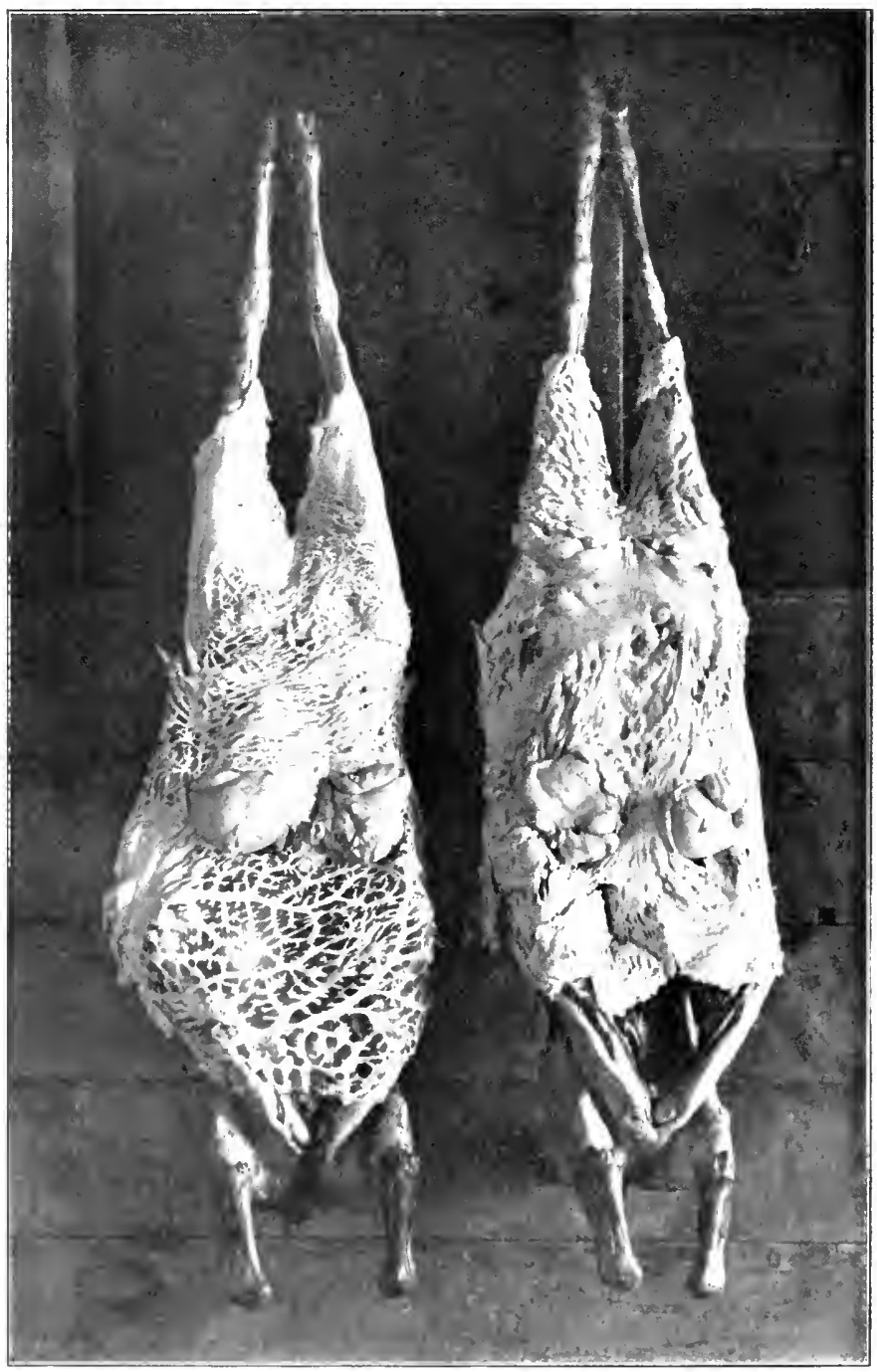

Iambe fattened at the Wyoming Station on alfalfa and native bay. Students are also given object-lessoms in dressing animals in all all ractive mammer. 
year. After the alkali lands of the arid region were proven to be unusually fertile, the further demonstration was made that they were rendered unproductive solely by the excess of various salts, that the total depth of these salts was usually not more than four or five feet from the surface, and that not only could these salts be removed to large degree by drainage, but that their re-ascent could be prevented simply by preventing surface evaporation-and this prevention was effected by means of deeper irrigation, called deep-furrow irrigation, the surface being kept dry while the earth around the roots is moist. 'Ihen, again, extensive chemical analyses of the waters in different portions of the arid regions were made so that the orchards should not be irrigated with water which, of itself, would work harm to the land. Certain portions of the desert had what is called black alkali, or carbonate of soda, which has been very difficult to combat. It was found that gypsum spread upon such soil neutralized the alkali. Investigation was at once set on foot, and a deposit of the gypsum was found by the station within the borders of the state itself, a never-failing supply. 


\section{THE NEW EARTH}

Thus, this second element in reclamation is seen to be of large importance, for it has resulted in the reclamation of land now worth millions of dollars, in addition to the still greater value, present and prospective, of the crops which come from the orchards upon these soils.

Third in the list of factors which have come into play since the beginning of the New Earth for the aid of man in the saving of these waste places is arid farming, now under full swing in the state of Utah, as well as under careful test in other states having arid regions. Briefly, by this is meant farming without water, or with so small a portion as to make it almost a negligible quantity, together with the adaptation of certain crops to these soils,-crops which, like the native desert plants, as the cactus and the chaparral, will grow with the very smallest appreciable portion of moisture. The Experiment Station of Utah has taken up this work and has pushed it to most satisfactory ends. In Utah, there are eighty-two thousand one hundred and ninety square miles of land, and even when as much as ten thousand square miles of this shall be supplied with water, 


\section{RECLAIMING THE EARTH}

which will be a long time in the future, there will be remaining nearly forty-five millions of acres still arid. Out of the eighty-two thousands of square miles in the state, only nine hundred and eighty-three square miles are now under irrigation. The problem in reclamation here has been, What can be done without water, or with the very smallest amount of water?

In the answering of this question some exceedingly interesting facts have been developed. It is so strange a thing, this farming in defiance of sun and heat and drought, it seems hard by the land of miracles.

When the discussion of the subject of arid farming was well under way, as a result of the preliminary experiments of the station, the state legislature of Utah enacted a bill providing for the establishment of five experimental farms in arid regions of the state, and it is largely upon these farms that the work has been carried on. One of the most important problems has been to make use of what little water does come in the way of rain or snow so to store this water in the soil, which in Utah is of unusual depth, that it may all be saved for 


\section{THE NEW EARTH}

the uses of the plants. And after the water was in the soil, the next problem was to select such crops as would get along with the least possible amount of water and yet yield abundantly.

The actual work on a large scale began in 1904, so that but little time has yet elapsed in the prosecution of the work, though a certain form of arid farming had been carried on by intelligent farmers in certain regions of the state long enough fully to justify the belief that the more extended work of the station would yield rich results. Tests were at once begun in careful analyses of the soils and in the selection of drought-resistant wheats, oats, millet, sugar-beets, vegetables, Kaffir corn, and so on. The farms were desert when the tests began, covered with sage brush, the very antithesis of fertility. The transformation wrought was complete, the desert was made a garden. While some of the tests were not satisfactory,as, indeed, was to be anticipated, as the work is essentially experimental at the start,--enough was developed to show that the arid farming in Utah has absolutely conquered the desert. An exhibition of the products of these dry 
farms, held in Salt Lake City, showing the splendid quality of crops grown, aroused the deepest interest,-it was an object-lesson in the possibilities of arid farming. So it appears conservative to say that on the hundreds of thousands, indeed millions, of arid acres, which are not likely to come under the influence of direct irrigation, profitable crops are now to be raised in absolute disregard of the sun and the drought.

Fourth among the significant factors in the reclamation of the desert lands of America, is the remarkable work of Luther Burbank in breeding cacti which are food both for man and beast. 'Through all the centuries, the cactus has been faithful to the desert, however bitter a foe to man and beast. It will thrive where, perhaps, no other vegetation will grow, and, taking this into account, Mr. Burbank spent many years of his life in breeding a cactus free from spines and thorns, and having a high per cent of nutriment. 'There were thornless cacti, or those practically so, in various parts of the world, but they were not of the type he wished, - not so rich, not capable of growing as he planned they should grow in all climates wher- 


\section{THE NEW EARTH}

ever any vegetation will live. He chose cacti from various portions of the globe, thornless and with thorns, bred them together in a wellnigh interminable succession of blendings and crossings, planted the seedlings from the crosses by the tens of thousands, and from these thousands made selection. Year by year he repeated the process, in order to secure precisely what he wished, always selecting those which came nearest his ideal. While, in 1906, he has not gotten the cactus in shape to give to the world as it will be given, free of all cost, still further work being under way upon it, he has demonstrated beyond all question that the thornless, edible cactus, not only rich in food in the juicy leaves, but with a fruit delicious to the taste and also highly nutritious, has come to the world to stay, to help redeem the desert, to be no more a foe to man, but his constant and never-failing helper.

This cactus is one of the greatest of all Mr. Burbank's great works. It will grow in any latitude - the temperate zones, the tropics, the arctics. It is food for man and food for beast. It is to work the transformation of the desert.

'Take these four great enterprises,-national 


\section{RECLAIMING THE EARTH}

aid in irrigation, the solution of problems in California, the introduction of arid farming, the production of this cactus: blend them if you will into one composite in your mind, and then try to estimate what these four steps in the advancement of the New Earth mean to the race. 'Truly, we are living in the age of miracles: best of all, they are practical miracles, rich in service to mankind. 


\section{CHAP'TER XIV}

THE FOODS OF THE NEW EARTH

TF any man more than another should be 1 well informed on the foods of the race, surely it is he without whom the food supply of the race vanishes. It is this man, the tiller of the New Earth, who supplies this food,wheat, corn, rice, meat, vegetables, fruits; the whole stock for the sustenance of the world comes from his hand. He is preëminently the purveyor of the race. If the material which he provides falls below normal, the race to a proportionate degree loses in vitality. If he maintains the integrity of the elements in his products, permanency is secured. If he increases the nutritive value of his food supplies so that, when prepared for the table, they will afford so many more per cents of heat for the body, so many more of muscular strength, so many of vitality, then he is leading the world upward in the betterment of his crops.

But not until the dawning of the New 


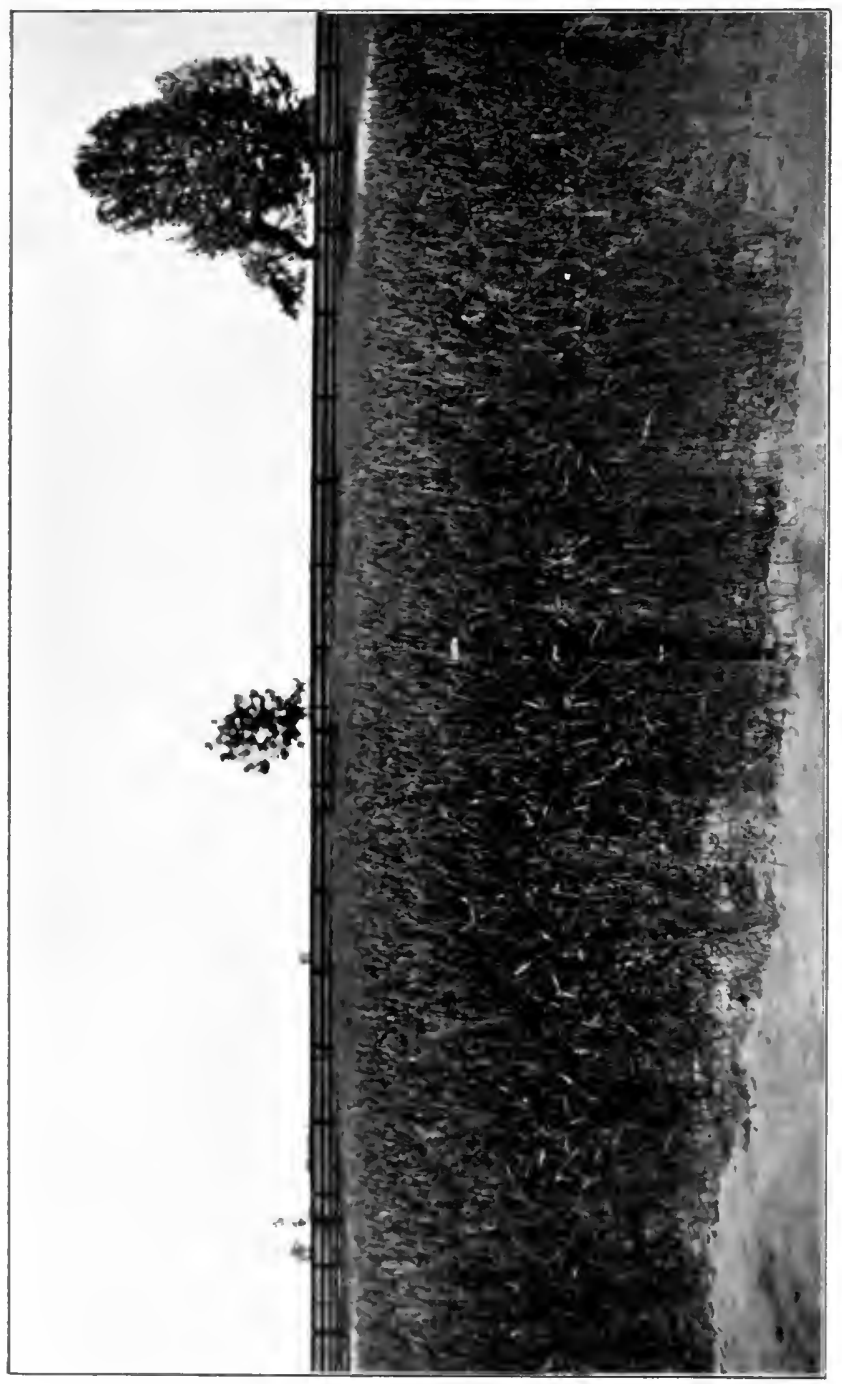

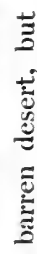

r

咅

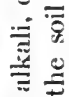

艺

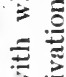

记

ت

芒

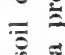

$\%$

훙

$\equiv$

范

¿ั.

$\therefore$

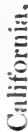

.

$\stackrel{3}{3}$

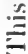





\section{THE FOODS OF THE NEW EARTH}

Earth, not, indeed, in some quarters even yet, have the producers of these supplies had any real knowledge of what food really is, what it does for the body, and how and why it does it. Nor are they alone in this lack of knowledge, for not until within the last generation, notably the last half of it, has any considerable portion of the general public of town and country come to any adequate idea of foods and food values. While the study of foods is not yet finished, and while there is much divergence of opinion as to food values among those who should be advancing upon the same or parallel lines, yet great progress has been made. Indeed, the investigations into foods, their nutritive values, their possibilities under new and novel conditions, as well as the investigations into the subject of food adulteration, - which adulteration, strangely enough, has arisen and most dangerously persisted in the period of this development of knowledge, have revolutionized the dietary of thousands. No doubt there will always be an abundance of more or less harmless fads in methods of preparing and eating foods, but out of the new order, nevertheless, is coming a greater meas- 


\section{THE NEW EARTH}

ure of true knowledge and a stronger race of men and women,- stronger physically and mentally; - the bearing upon manners and morals may indeed be not less pronounced. I fancy there are few, on or off the farm, who are not becoming convinced that they eat too much. Starvation never follows moderation, but ultimate starvation has come to many a worn-out, over-fed stomach pushed for half a lifetime to excess.

I question if there is any department of human activity in which men are engaged with greater zest than in the development of the knowledge of foods. In the agricultural schools, the preparatory and training schools, in normal institutions, and in the universities themselves, everywhere the leaven is working. Scientific men, realizing not only that great additions to human knowledge should follow researches along this line, but that out of the investigation should come vast good for the race, have followed these lines of work with the keenest interest. 'Today the results of these investigations may be the property of the tillers of the soil. 'They are practical results, having a distinct and helpful bearing 


\section{THE FOODS OF 'THE NEW EAR'TH}

upon health. More than that, for out of the knowledge now made available as to foods and their values comes happiness, too. Of all men most miserable is he who suffers from dyspeptic torture, that cruel legacy of ignorance. The man who has learned what to eat and why, who knows why certain foods are harmful and how he may supply their place with other foods just as nutritious and toothsome, has found a road that leads through happy fields.

How thoroughly practical is this newer knowledge was brought clearly home to me one day as an agricultural chemist in his laboratory was proving the heating power of a vegetable,--what it would do in the way of giving a man fuel to keep up the fires of vitality in his own body. It was a fine illustration of the many ways in which the knowledge of the New Earth has been broadened and deepened. He had before him on the table a stout tube about eight inches long by four inches in diameter. It was solid stecl save for a small platinum-lined cavity in the center. In this cavity he placed a little brown pellet, looking quite like a cough lozenge. It had been 


\section{THE NEW EARTH}

pressed into its present shape by means of a powerful lever. It was a condensed squash, so to call it, for this was the vegetable he was testing. He had under the powerful apparatus compressed quite a portion of the squash into this little pellet. Down in the center of the bomb, as the steel receptacle was called, was suspended a tiny, black, thread-like wire of pure iron. The cap of the bomb was screwed on, and the bomb was placed in a pail of water in which stood a thermometer so delicately graduated that it would measure to the one-thousandth of a degree. 'Then the current of electricity was turned on, the iron wire caught fire, burned down to the pellet and set it ablaze, the pellet was consumed, and the heat made in the burning passed out through the walls of steel, warmed the water and was measured upon the thermometer. It was not much heat, to be sure, but it was all recorded as accurately as though it had been a thousand degrees.

The object of this test was to prove just how much fuel, so to speak, there was in the squash, in order to show clearly just ho'v valuable it would be as a food; for precisely the 


\section{THE FOODS OF THE NEW EARTH}

same act would take place if the squash were fed to a human being,-it would give off the same heat that was measured on the thermometer, and the body would have made use of it. The steel tube, in technical words, was a bomb calorimeter. In order to get a working basis, the scientific men established what they call a calorie. It is simply a unit of measure. It is the amount of heat which would be needed to increase the temperature of a pound of water four degrees by the Fahrenheit thermometer, or one and eight-tenths by the Centigrade. Or it may be measured in energy. Thus the one calorie, if put into power, as in a steam engine, would lift one ton a foot and a half. Just as in coal there is what is called latent heat, heat in reality which is in waiting for the fire to come and turn it into actual heat to warm us or cook our food, or run our steamer across the ocean, so there is in foods this latent heat waiting to be given out into the body in the processes of digestion. The calorimeter gives the opportunity of measuring just how much latent heat there is in foods, so that it becomes possible to tell of any food just how valuable it is for body fuel. 


\section{THE NEW EARTH}

In another room in the same building, three times a day, six young men met to eat their meals. The food given them was under test. It was weighed and measured with the utmost care. One young man had one kind of meal, that is, a certain ration which he kept through the test; the others, other rations. Every particle of waste was accounted for, so that the actual value of each food was determined. It was quite as though an engine was being fed a certain amount of coal and a careful record kept of all the refuse, as well as of all the work the coal did in the engine. The most careful and painstaking records were kept during the week the foods were under test, and, at the end of that time, after having made careful laboratory tests of the value of the foods, determined by artificial digestion experiments, the professor in charge was able to come to a very clear and accurate statement of just, what the different foods were worth, and also to determine the relative value of the different styles of rations.

Still different and more extensive is the test made in the respiration calorimeter. In this apparatus the small cavity in the steel bomb 


\section{THE FOODS OF THE NEW EARTH}

is expanded to a large cavity, so to call it,- $-\mathrm{a}$ room,- and the steel walls of the bomb to the copper-lined walls of the room. In place of a pellet of squash in the bomb, a man is placed in the room and on him tests are made, absolute, though not so heroic in character as those which burned the little pellet to ash. Still, the test made is precisely as accurate. Out of this respiration calorimeter is coming some of the most valuable and practical information which has been developed in the period of the New. Earth. A man is kept in this room for a certain number of days-say a week or a fortnight. As in the case of the young men under test referred to above,-though they went about their regular work in the open as usual, - full and accurate data and records are kept of everything pertaining to the man in the cage, together with the composition of the foods fed, their amount, and so on. But much more is done than this. Not only is every particle of waste determined, and how much food is left unconsumed in this waste as it comes from the intestines and kidneys, but how much waste is given off through the lungs in breathing. More than this, too, every particle of muscular 


\section{THE NEW EARTH}

energy is recorded, so that it will be easy to show just how much heat the man is throwing off from his body in this way, for with every movement of the body some heat is generated. In the room, - a small room, seven feet and a half by four feet in dimensions, and six and a half feet high,- -is a stationary bicycle for exercise, in case the test is chiefly to show the amount of heat developed in muscular activity. Outside the room is a delicately adjusted thermometer, so sensitive, indeed, that it will record any fraction of a degree of heat. 'The observer who is keeping the record on the outside of the room does not need to look in or to hear any sound from the man inside to know when he rises from his chair, for instance, for the act, though slight and unaccompanied by any special exertion, is yet sufficient to throw off enough heat to cause an immediate rise in the thermometer.

The air which the man in the room breathes is tested, also, with the utmost care. It passes in to him absolutely pure. It comes out impure from his breathing, and all this impurity is accurately measured by a delicately adjusted apparatus. Sometimes the test will be mus- 


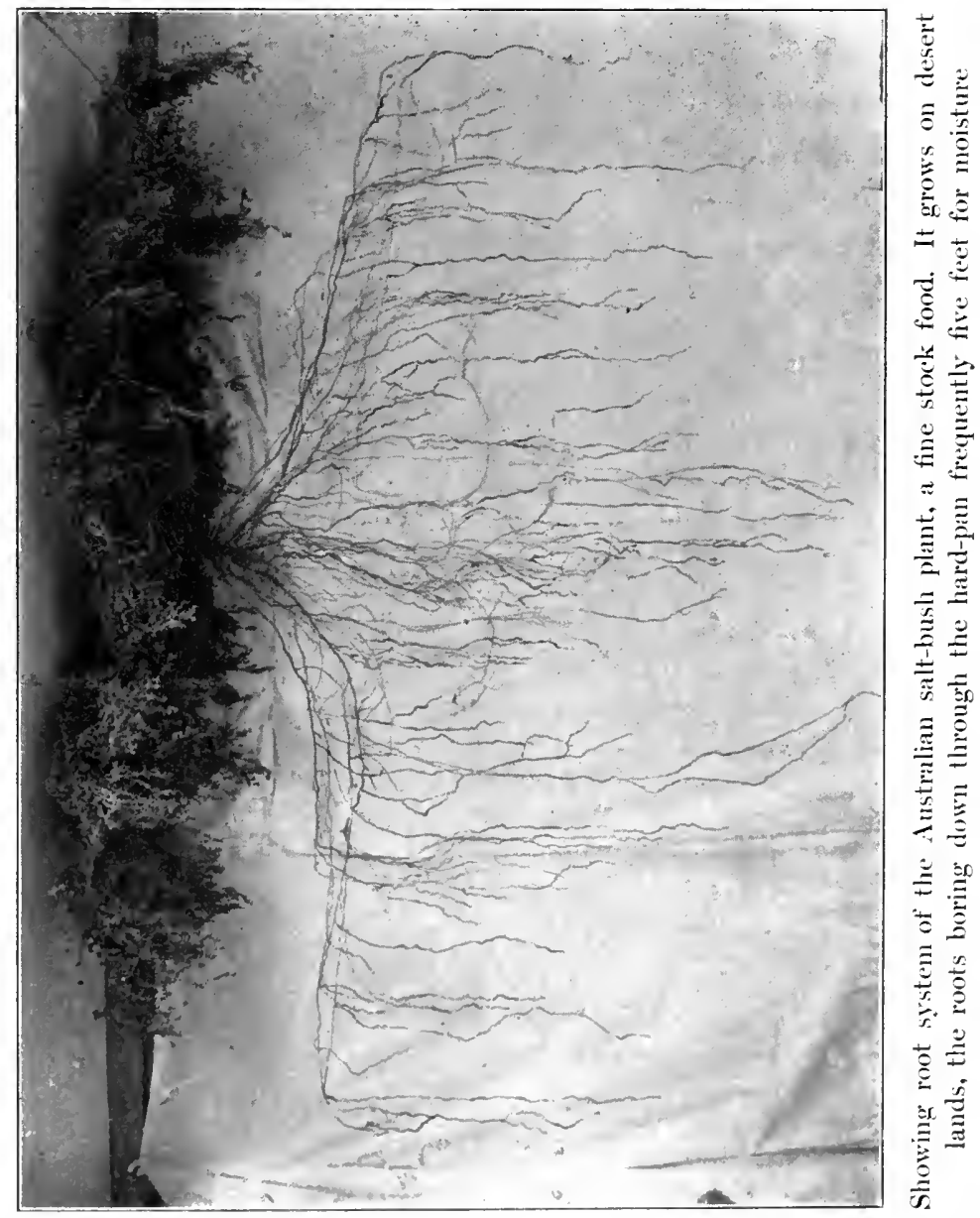


\section{THE FOODS OF THE NEW EARTH}

cular, so to call it; sometimes the man will do absolutely no muscular work while in the room but merely be passive; sometimes he will do no muscular work, but will give himself up to the very severest sort of mental labor; all this in order that the value of the foods given may be determined under different conditions of rest and action.

In this very definite and practical, as well as strictly scientific way, the sum of knowledge of food values has been, and still is being, immensely increased. The work in this line, which has been carried on by Prof. W. O. Atwater, of the Storrs Experiment Station in Connecticut, in coöperation with the Department of Agriculture in Washington, has been of marked importance. It is one of the vital and significant advances of the New Earth.

In addition to all the important data assembled as to the value of foods, the relative value of foods, and the needs of man's body for foods, Professor Atwater has demonstrated that the law of the conservation of matter and the law of the conservation of energy are absolutely maintained in the intricate and delicate functions of the human body, that no particle 
of energy or force and no particle of matter is lost under any circumstances,-it is all accounted for, one of the significant scientific demonstrations of recent years.

At the Pennsylvania Experiment Station, a similar series of experiments has been under way with cattle kept in a larger compartment, but managed in the same general way. The results have been of much interest and value in the determination of the relative importance of stock foods.

While food investigations have been carried on in a more or less primitive way for the last seventy-five years in Europe, and for a lesser period in the United States, it is only within recent years that important work like this has been undertaken. Professor Atwater notes the fact that the chemical substances of which the body is composed are very similar to those of the foods which nourish the body. Here, again, the man of the New Earth may discover a remarkable likeness between himself and the raw material which he provides for the support of the race, just as he could discover marked likenesses between himself and the plant-life about him. Four compounds at least are in- 


\section{THL FOODS OF THE NEW EARTH}

dispensable in his body and in his foods, just as there was a fundamental quartette at the basis of the harmony of plant-life. 'These four are protein, which is the nitrogenous compound in foods, - the lean of meats, the white of eggs, the gluten of wheat, and so on, which go to make up the muscular portion of the body; the carbohydrates, which include the starches and sugars, affording energy or power, -fuel as it may be called; the fats, which are found in meats, fish, butter and the like, and to some extent in vegetables, noticeably large in the olive and cotton seed, which afford a more concentrated fuel; and, lastly, the mineral matter which goes to make up the skeleton or framework of the body. The protein builds up and repairs; for, in so complicated a machine as that of the human body, run at such high tension for so many years without stopping, there must, of necessity, be breakdowns and wastage, while, at the same time, the protein adds to the fuel supply. 'The fats and the starches when burned up in the body, just as the pellet of squash was burned up in the bomb, provide heat and power alone. Fat is formed in the body, too, and it serves as a 


\section{THE NEW EARTH}

source of stored-up fuel against a day of disease or sickness. In the words of Professor Atwater, the differences between the material taken into the body by the man who is in the test, and the material given off from his body during the test, is the balance of matter-it shows whether or not the body is gaining or losing material; while the difference between the energy of the food he eats and the energy given off from the body as heat and muscular work and waste, is the balance of energy, and should equal the energy of the body material gained or lost. 'The following table, though somewhat extended, is of interest in this connection. It is taken from the bulletin of the United States Department of Agriculture on the subject, and gives, in a condensed form, the now generally accepted facts in Europe and America as to the nutritive value of foods, their waste, their chief constituents, and their fuel value per pound of material in calories. It will be found that this table will warrant extended consideration on the part of any one interested in the sensible study of foods and food values, and will prove valuable for reference when any particular food is under discussion: 


\section{THE FOODS OF THE NEW EARTH}

\section{Average Compostrion of Common American Food Products}

\begin{tabular}{|c|c|c|c|c|c|c|c|}
\hline $\begin{array}{l}\text { FoOd MATERIALS } \\
\text { (as purchased) }\end{array}$ & 总 & 总 & 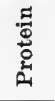 & $\underset{\omega}{\vec{\omega}}$ & 究怘 & $\stackrel{5}{4}$ & 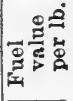 \\
\hline $\begin{array}{l}\text { ANIMaL FOOD } \\
\text { Beef, fresh- }\end{array}$ & $\begin{array}{l}\text { Per } \\
\text { cent }\end{array}$ & $\begin{array}{l}\text { Per } \\
\text { cent }\end{array}$ & $\begin{array}{l}\text { Per } \\
\text { cent }\end{array}$ & $\begin{array}{l}\text { Per } \\
\text { cent }\end{array}$ & $\begin{array}{l}\text { Per } \\
\text { cent }\end{array}$ & $\begin{array}{l}\text { Per } \\
\text { ct. }\end{array}$ & $\begin{array}{l}\text { Calo- } \\
\text { ries }\end{array}$ \\
\hline Chuck ribs ............ & 16.3 & 52.6 & 15.5 & 15.0 & & 0.8 & 910 \\
\hline & 10.2 & 54.0 & 17.0 & 19.0 & & .7 & 1,105 \\
\hline & 13.3 & 52.5 & 16.1 & 17.5 & .... & .9 & 1,025 \\
\hline Por & 12.7 & 52. & 19.1 & 17.9 & .... & .8 & 1,100 \\
\hline & 12.8 & 54.0 & 16.5 & 16.1 & $\ldots$ & .9 & 975 \\
\hline & 27.6 & 45 & 14.5 & 11.9 & $\ldots$ & .7 & 1,165 \\
\hline Ribs & 20.8 & & 13 & & & .7 & 1,135 \\
\hline & & & 19. & 16.7 & .. & .9 & 1,055 \\
\hline & 7.2 & 60 & 19. & & $\ldots$ & 1.0 & 890 \\
\hline $\operatorname{Ru}$ & 20.7 & & 13. & & $\ldots$ & .7 & 1,090 \\
\hline & 36.9 & 42.9 & 12.8 & 7.3 & .... & .6 & 545 \\
\hline Sh & 16.4 & 56.8 & 16.4 & & $\ldots$ & .9 & 715 \\
\hline For & 18.7 & 49 & 14.5 & 17.5 & .. & .7 & 995 \\
\hline Hind quarter...$\ldots \ldots \ldots \ldots \ldots \ldots$ & 15.7 & 50.4 & 15.4 & 18.3 & ... & .7 & 1,045 \\
\hline \multicolumn{8}{|l|}{ Beef, corned, canned, pickled and } \\
\hline Corned beef $\ldots . . . . . \ldots \ldots \ldots \ldots \ldots$ & 8.4 & 49.2 & 14.3 & 23.8 & .... & 4.6 & 1,245 \\
\hline & 6.0 & 58 & 11. & 19. & .... & 4.3 & 1,010 \\
\hline & 4.7 & 53. & 26. & 6.9 & ... & 8.9 & 790 \\
\hline & .... & 51. & 25.5 & 22.5 & .... & 1.3 & 1,410 \\
\hline & .... & 51 & 26.3 & 18.7 & ... & 4.0 & 1,270 \\
\hline \multicolumn{8}{|l|}{ Veal- } \\
\hline & 21.3 & 52.0 & 15.4 & 11.0 & & .8 & 745 \\
\hline & 14.2 & 60 . & 15. & 7.9 & .... & .9 & 625 \\
\hline & 3.4 & 68 & & & .... & 1.0 & 695 \\
\hline & 24.5 & 54 & 15. & 6.0 & .... & .7 & 535 \\
\hline Hind qu & 20.7 & 56.2 & 16.2 & 6.6 & ... & .8 & 580 \\
\hline \multicolumn{8}{|l|}{ Mutton- } \\
\hline & 9.9 & 39.0 & 13.8 & 36.9 & & .6 & 1,770 \\
\hline I & 18.4 & 51 & 15. & & • & .8 & 890 \\
\hline & 16.0 & 42 & 13. & & $\cdots$ & .7 & 1,415 \\
\hline & 21.2 & 41 & 12.3 & & • & .7 & 1,235 \\
\hline Hind quarter, without tallow. & 17.2 & 45.4 & 13.8 & 23.2 & ... & .7 & 1,210 \\
\hline \multicolumn{8}{|l|}{ Lamb- } \\
\hline & 19.1 & 45.5 & 15.4 & 19.1 & .. & .8 & 1,075 \\
\hline Leg, & 17.4 & 52.9 & 15.9 & 13.6 & & .9 & 860 \\
\hline \multicolumn{8}{|l|}{ Pork, fresh- } \\
\hline Ham........ & 10.7 & 48.0 & 13.5 & 25.9 & & .8 & 1,320 \\
\hline & 19.7 & & 13 & 24.2 & ... & .8 & 1,245 \\
\hline & 12.4 & 44.9 & 12.0 & 29.8 & ... & .7 & 1,450 \\
\hline Tenderloin . & & 66.5 & 18.9 & 13.0 & & 1.0 & 895 \\
\hline \multicolumn{8}{|l|}{ Pork, salted, cured and pickled- } \\
\hline & 13.6 & 34.8 & 14.2 & 33 & & 4.2 & 1,635 \\
\hline & 18.2 & 36.8 & 13.0 & & .... & 5.5 & 1,335 \\
\hline & & 7.9 & 1.9 & 86.2 & & 3.9 & 3,555 \\
\hline Bacon, smoked ...... & 7.7 & 17.4 & 9.1 & 62.2 & .... & 4.1 & 2,715 \\
\hline
\end{tabular}




\section{THE NEW EARTH}

\section{Average Composition of Common American Food Products}

continued

\begin{tabular}{|c|c|c|c|c|c|c|c|}
\hline $\begin{array}{l}\text { Food MATERIALS } \\
\text { (as purchased) }\end{array}$ & $\begin{array}{l}\text { : } \\
\text { : } \\
\text { : } \\
\text { D. }\end{array}$ & 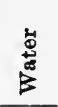 & $\begin{array}{l}\stackrel{1}{0} \\
\stackrel{\$}{\circ} \\
\stackrel{\circ}{4}\end{array}$ & 营 & 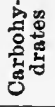 & $\frac{5}{4}$ & 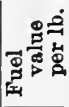 \\
\hline $\begin{array}{l}\text { ANIMAL FOOD, cont } \\
\text { Sauge- }\end{array}$ & $\begin{array}{l}\text { Per } \\
\text { cent }\end{array}$ & $\begin{array}{l}\text { Per } \\
\text { cent }\end{array}$ & $\begin{array}{l}\text { Per } \\
\text { cent }\end{array}$ & $\begin{array}{l}\text { Per } \\
\text { cent }\end{array}$ & $\begin{array}{l}\text { Per } \\
\text { cent }\end{array}$ & $\begin{array}{l}\text { Per } \\
\text { et. }\end{array}$ & $\begin{array}{l}\text { Calo- } \\
\text { ries }\end{array}$ \\
\hline & 3.3 & 55.2 & 18.2 & 19.7 & & 3.8 & 1,155 \\
\hline Pork ... & .... & 39.8 & 13.0 & 44.2 & 1.1 & 2.2 & 2,075 \\
\hline Frankfort .......... & $\cdots$ & 57.2 & 19.6 & 18.6 & 1.1 & 3.4 & 1,155 \\
\hline Soups- & & & & & & & \\
\hline Celery, c & .... & 88.6 & 2.1 & 2.8 & 5.0 & 1.5 & 235 \\
\hline $\mathrm{Be}$ & $\cdots$ & 92. & 4. & .4 & 1.1 & 1.2 & 120 \\
\hline Meat ste & .... & 84. & 4.6 & 4.3 & 5.5 & 1.1 & 365 \\
\hline Tomato. & $\cdots \cdot$ & 90.0 & 1.8 & 1.1 & 5.6 & & 185 \\
\hline ren, broilers & 41.6 & 437 & 128 & & & & \\
\hline For & 25.9 & 47.1 & 13.7 & $\begin{array}{r}1.4 \\
12.3\end{array}$ & $\cdots$ & .7 & $\begin{array}{l}305 \\
765\end{array}$ \\
\hline & 17.6 & 38. & 13. & 29.8 & ..... & .7 & 1,475 \\
\hline Turkey. & 22.7 & 42.4 & 16.1 & 18.4 & .... & .8 & 1,060 \\
\hline Fish- & & & & & & & \\
\hline Cod, dres & 29.9 & 58.5 & 11.1 & .2 & & .8 & 220 \\
\hline & 17.7 & 61. & 15. & 4.4 & & .9 & 475 \\
\hline Ma & 44.7 & 40. & 10.2 & 4.2 & .... & .7 & 370 \\
\hline $\mathrm{Pe}$ & 35.1 & & 12. & & .... & .9 & 275 \\
\hline Shad & 50.1 & 35. & 9.4 & 4.8 & 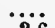 & .7 & 380 \\
\hline Shad, ro & .... & 71.2 & 20.9 & 3.8 & 2.6 & 1.5 & 600 \\
\hline Fish, preserved- & & & & & & & \\
\hline $\begin{array}{l}\text { Cod, } \\
\text { Herri }\end{array}$ & 24.9 & 40.2 & 16.0 & .4 & .... & 18.5 & 325 \\
\hline $\begin{array}{r}\text { Herri } \\
\text { Fish, ca }\end{array}$ & 44.4 & 19.2 & 20.5 & 8.8 & $\cdots \cdot$ & 7.4 & 755 \\
\hline $\begin{array}{l}\text { Fish, } \\
\text { Sal }\end{array}$ & & 63.5 & 21.8 & 12.1 & & & \\
\hline Sard & *5.0 & 53.6 & 23.7 & 12.1 & .... & 5.3 & $\begin{array}{l}915 \\
950\end{array}$ \\
\hline Shell & & & & & & & \\
\hline "sollds & .... & 88.3 & 6.0 & 1.3 & 3.3 & 1.1 & 225 \\
\hline & & & 10.6 & 1.7 & 5.2 & 2.3 & 340 \\
\hline & 52.4 & & 7. & .9 & .6 & 1.5 & 200 \\
\hline & 61.7 & 30.7 & 5.9 & .7 & .2 & .8 & 145 \\
\hline Eggs - Hens' eggs ......... & $\dagger 11.2$ & 65.5 & 13.1 & 9.3 & $\cdots$ & 0.9 & 635 \\
\hline 9air & & & & & & & \\
\hline & & 11.0 & 1.0 & 85.0 & & 3.0 & 3,410 \\
\hline & & 87. & 3. & 4.0 & 5.0 & .7 & 310 \\
\hline & $\cdots$ & 90. & 3. & .3 & 5.1 & .7 & 165 \\
\hline & ... & & 3. & .5 & 4.8 & .7 & 160 \\
\hline & .... & & 8. & 83 & 54.1 & 1.9 & 1,430 \\
\hline & $\cdots \cdot$ & 74.0 & 2 & & 4.5 & .5 & 865 \\
\hline & $\cdots$ & 27.4 & 27.7 & & 4.1 & 4.0 & 2,075 \\
\hline Cheese, full cream.... & .... & 34.2 & 25.9 & 33.7 & 2.4 & 3.8 & 1,885 \\
\hline
\end{tabular}

* Refuse, oil.

†Refuse, shell. 


\section{THE FOODS OF THE NEW EARTH}

\section{Average Composition of Common American Food Products}

continued

\begin{tabular}{|c|c|c|c|c|c|c|c|}
\hline $\begin{array}{l}\text { Food MatkRIals } \\
\text { (as purchased) }\end{array}$ & 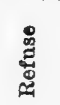 & 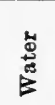 & 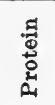 & 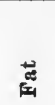 & 客䍘 & 离 & 焉 \\
\hline $\begin{array}{l}\text { VEgetable FOOD } \\
\text { Flour megl etc- }\end{array}$ & $\begin{array}{l}\text { Per } \\
\text { cent }\end{array}$ & $\begin{array}{l}\text { Per } \\
\text { cent }\end{array}$ & $\begin{array}{l}\text { Per } \\
\text { cent }\end{array}$ & $\begin{array}{l}\text { Per } \\
\text { cent }\end{array}$ & $\begin{array}{l}\text { Per } \\
\text { ecrit }\end{array}$ & $\begin{array}{l}\text { Per } \\
\text { et. }\end{array}$ & $\begin{array}{l}\text { Calo. } \\
\text { ries }\end{array}$ \\
\hline $\begin{array}{l}\text { Flour, meal, etc.- } \\
\text { Entire-wheat flonr................ }\end{array}$ & (60) & 11.4 & 13.8 & 1.9 & 71.9 & 1.0 & 1.650 \\
\hline $\begin{array}{l}\text { Graham flour....................... } \\
\text { Wheat flour, patent roller pro } \\
\text { cess }-\end{array}$ & .... & 11.3 & 13.3 & 2.2 & 71.4 & 1.8 & 1,645 \\
\hline High-grade and medinm....... & .... & 12.0 & 11.4 & 1.0 & 75.1 & .5 & 1,635 \\
\hline Low grade. & & 12.0 & 14.0 & 1.9 & 71.2 & .9 & 1,640 \\
\hline Macaronl, ve & ..... & 10.3 & 13.4 & .9 & 74.1 & 1.3 & 1,645 \\
\hline Wheat breakfast food & .... & 9.6 & 12.1 & 1.8 & 75.2 & 1.3 & 1,680 \\
\hline Buckwheat & & 13.6 & 6.4 & 1.2 & 77.9 & .9 & 1,605 \\
\hline Rye flour.. & $\ldots$ & 12.9 & 6.8 & .9 & 78.7 & .7 & 1,620 \\
\hline Corn meal. & …. & 12.5 & 9.2 & 1.9 & 75.4 & 1.0 & 1.635 \\
\hline Oat breakfast food & & 7.7 & 16.7 & 7.3 & 66.2 & 2.1 & 1,800 \\
\hline Rice & $\ldots$ & 12.3 & 8.0 & .3 & 79.0 & .4 & 1,620 \\
\hline Tapioca.. & .... & 11.4 & .4 & .1 & 88.0 & .1 & 1,650 \\
\hline Starch.............. & $\ldots$ & Ant & $\ldots$. & $\ldots$. & 90.0 & .. & 1,675 \\
\hline Bresd, pastry, etc.- & & & & & & & \\
\hline Whi & .... & 35.3 & 9.2 & 1.3 & 53.1 & 1.1 & 1,200 \\
\hline Brown brea & $\ldots$ & 43.6 & 5.4 & 1.8 & 47.1 & 2.1 & 1,040 \\
\hline Gra & .... & 35.7 & 8.9 & 1.8 & 52.1 & 1.5 & 1,195 \\
\hline Whe & .... & 38.4 & 9.7 & .9 & 49.7 & 1.3 & 1,130 \\
\hline Rye bread. & ..... & 35.7 & 9.0 & .6 & 53.2 & 1.5 & 1,170 \\
\hline Cal & .... & 19.9 & 6.3 & 9.0 & 63.3 & 1.5 & 1,630 \\
\hline Cre & & 6.8 & 9.7 & 12.1 & 69.7 & 1.7 & 1,925 \\
\hline Oyst & $\ldots$ & 4.8 & 11.3 & 10.5 & 70.5 & 2.9 & 1,910 \\
\hline Soda crac & $\ldots$. & 5.9 & 9.8 & 9.1 & 73.1 & 2.1 & 1,875 \\
\hline Sugars, etc. - & & & & & & & \\
\hline & & .... & & & 70.0 & .. & 1,225 \\
\hline Candy*.... & ..... & ..... & $\ldots .$. & $\ldots .$. & 96.0 & $\ddot{. .}$ & 1,680 \\
\hline Honey ...... & ..... & .... & .... & $\cdots$ & 81.0 & & 1,420 \\
\hline Suga & $\ldots$. & $\ldots$. & .... & $\ldots$. & 100.0 & .. & 1,750 \\
\hline Maple syrup... & $\ldots$ & .... & $\ldots$ & $\ldots$ & 71.4 & .. & 1,250 \\
\hline Vegetables †- & & & & & & & \\
\hline $\mathrm{Be}$ & $\ldots$. & 12.6 & 22.5 & 1.8 & 59.6 & 3.5 & 1,520 \\
\hline elled & & 68.5 & 7.1 & .7 & 22 & 1.7 & 540 \\
\hline Bea? & 7.0 & 83.0 & 2.1 & .3 & 6.9 & .7 & 170 \\
\hline Beet & 20.0 & 70.0 & 1.3 & .1 & 7.7 & .9 & 160 \\
\hline$\cdots$ & 15,0 & 77.7 & 1.4 & .2 & 4.8 & .9 & 115 \\
\hline Celer & 20.0 & 75.6 & .9 & .1 & 2.6 & .8 & 65 \\
\hline Corn, green (sweet) edible portion & .... & 75.4 & 3.1 & 1.1 & 19.7 & .7 & 440 \\
\hline
\end{tabular}

- Plain confectionery not containing nuts, fruit, or chocolate.

+ Such vegetables as potatoes, squash, beets, etc., have a certain amount of inedible material, skin, seeds, etc. The amount varies with the method of preparing the vegetables, and can not be accurately estimated. The figures given for refuse of vegetables, fruits, etc., are assumed to represent approximately the amonnt of refuse in these foods as ordinarily prepared. 


\section{THE NEW EARTH}

\section{Average Composition of Common American Food Products}

continued

\begin{tabular}{|c|c|c|c|c|c|c|c|}
\hline $\begin{array}{l}\text { Food Materials } \\
\text { (as purchased) }\end{array}$ & 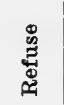 & 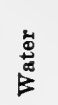 & 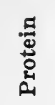 & 悹 & 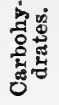 & $\frac{1}{80}$ & 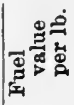 \\
\hline VEOETABLE FOOD, continued & Per & Per & & Per & & Per & Cal \\
\hline Vegetables, contlnued- & cent & cent & cent & cent & cent & ct. & ries \\
\hline Cucumbers ............. & 15.0 & 81.1 & .7 & .2 & 2.6 & .4 & 65 \\
\hline Lettuce...... & 15.0 & 80.5 & 1.0 & .2 & 2.5 & .8 & 65 \\
\hline Mushrooms.. & & 88.1 & 3.5 & .4 & 6.8 & 1.2 & 185 \\
\hline Onions ... & 10.0 & 78.9 & 1.4 & .3 & 8.9 & .5 & 190 \\
\hline Parsnips $\ldots \ldots \ldots \ldots \ldots \ldots$ & 20.0 & 66.4 & 1.3 & .4 & 10.8 & 1.1 & 230 \\
\hline Peas (Pisum sativum), dried.... & & 9.5 & 24.6 & 1.0 & 62.0 & 2.9 & 1,565 \\
\hline Peas (Pisum sativum), shelled.. & $\ldots$ & 74.6 & 7.0 & .5 & 16.9 & 1.0 & 440 \\
\hline Cow-peas, dried ............... & & 13.0 & 21.4 & 1.4 & 60.8 & 3.4 & 1,505 \\
\hline Potatoes... & 20.0 & 62.6 & 1.8 & .1 & 14.7 & .8 & 295 \\
\hline Rhy & 40.0 & 56.6 & .4 & .4 & 2.2 & .4 & 60 \\
\hline potatoes..... & 20.0 & 55.2 & 1.4 & .6 & 21.9 & .9 & 440 \\
\hline Spir & & 92.3 & 2.1 & .3 & 3.2 & 2.1 & 95 \\
\hline Squ & 50.0 & 44.2 & .7 & .2 & 4.5 & .4 & 100 \\
\hline Tom & & 94.3 & .9 & .4 & 3.9 & .5 & 100 \\
\hline Turnips................ & 30.0 & 62.7 & .9 & .1 & 5.7 & .6 & 120 \\
\hline Vegetables, canned- & & & & & & & \\
\hline Baked bea & & 68.9 & 0.9 & 2.5 & 19.6 & 2.1 & 555 \\
\hline Peas (Pisum sativum), green.. & .... & 85.3 & 3.6 & .2 & 9.8 & 1.1 & 235 \\
\hline 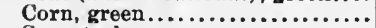 & & 76.1 & 2.8 & 1.2 & 19.0 & .9 & 430 \\
\hline Sue & & 75.9 & 3.6 & 1.0 & 18.6 & .9 & 425 \\
\hline Tomatoes..................... &. & 94.0 & 1.2 & .2 & 4.0 & .6 & 95 \\
\hline Fruits, berries, etc., fresh *- & & & & & & & \\
\hline & 25.0 & 63.3 & 3 & .3 & 10.8 & .3 & 190 \\
\hline & 35.0 & 48.9 & .8 & .4 & 14.3 & .6 & 260 \\
\hline & 25.0 & 58.0 & 1.0 & 1.2 & 14.4 & .4 & 295 \\
\hline & 30.0 & 62.5 & .7 & .5 & 5.9 & .4 & 125 \\
\hline $\mathrm{Mu}$ & 50.0 & 44.8 & .3 & & 4.6 & .3 & 80 \\
\hline & 27.0 & 63.4 & .6 & .1 & 8.5 & .4 & 150 \\
\hline Pear & 10.0 & 76.0 & .5 & .4 & 12.7 & .4 & 230 \\
\hline ible portior & .... & 66. & .8 & .7 & 31.5 & .9 & 550 \\
\hline Ra: & $\cdots$ & 85.8 & 1.0 & & 12.6 & .6 & 220 \\
\hline Stran & $\ddot{5.0}$ & 85.9 & .9 &.$\ddot{6}$ & 7.0 & .6 & 150 \\
\hline Waterme & 59.4 & 37.5 & .2 & .1 & 2.7 & .1 & 50 \\
\hline Fruits, & & & & & & & \\
\hline & & 28.1 & 1.6 & 2.2 & 66.1 & 2.0 & 1,185 \\
\hline Apr & & 29.4 & 4.7 & 1.0 & 62.5 & 2.4 & 1,125 \\
\hline & 10.0 & 13. & 1.9 & 2.5 & 70.6 & 1.2 & 1,275 \\
\hline & & 18.8 & 4.3 & .3 & 74.2 & 2.4 & 1,280 \\
\hline Raisins .......................... & 10.0 & 13.1 & 2.3 & 3.0 & 68.5 & 3.1 & 1,265 \\
\hline
\end{tabular}

* Fruits contain a certain proportion of inedible materials, as skin, seeds, etc., which are properly classed as refuse. In some fruits, as oranges and prunes, the amount rejected in eating is practicaliy the same as refuse. In others, as apples and pears, more or less of the edible material is ordinarily rejected with the skin and seeds and other inedible portions. The edible material which is thus thrown away, and should properly be classed with the waste, is here classed with the refnse. 


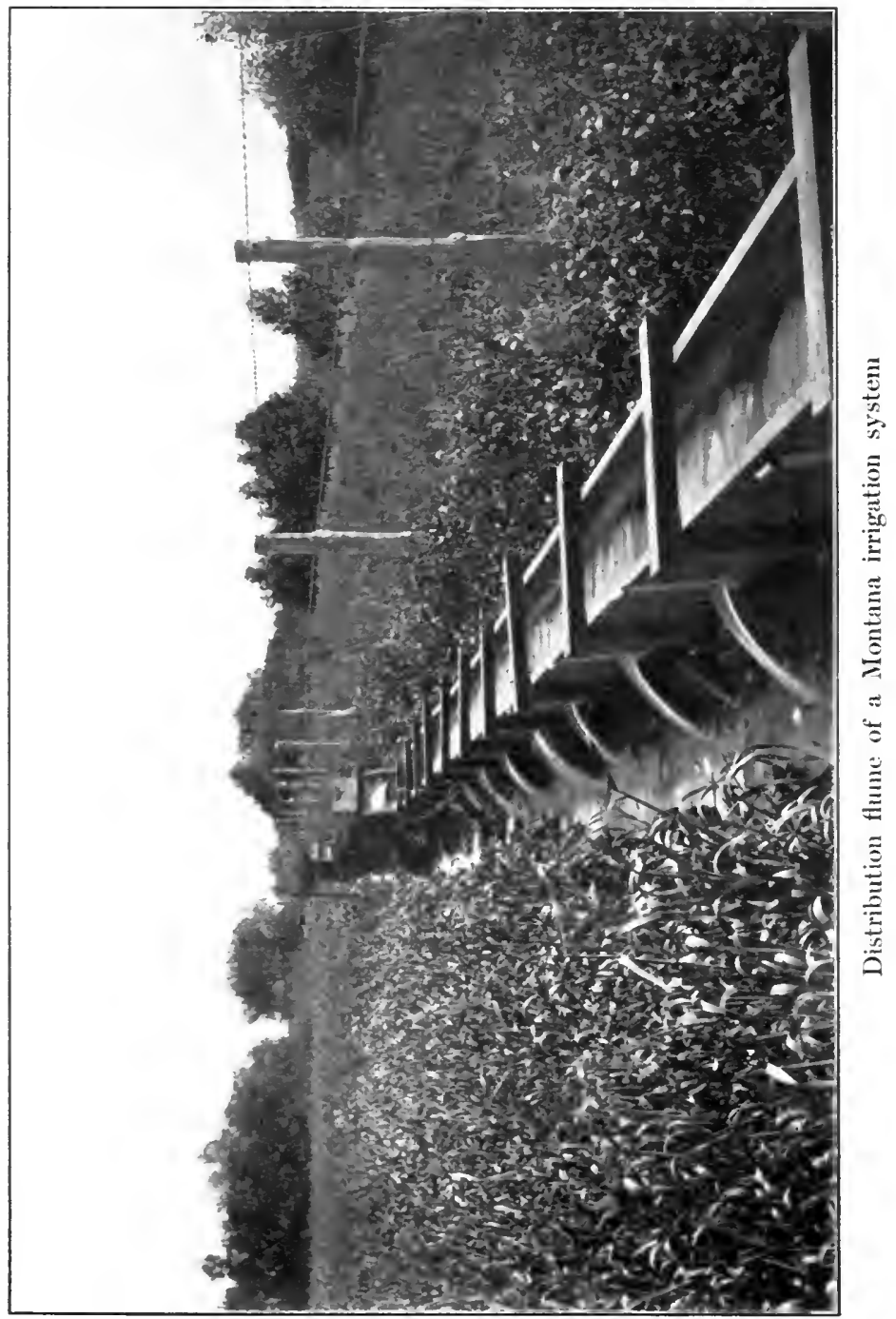




$$
\text { . }
$$




\section{THE FOODS OF THE NEW EARTH}

\section{Average Composition of Common American Food Products}

continued

\begin{tabular}{|c|c|c|c|c|c|c|c|}
\hline $\begin{array}{l}\text { FoOd MatrRials } \\
\text { (as purchased) }\end{array}$ & 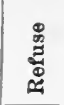 & 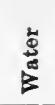 & 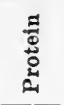 & 崫 & 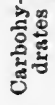 & $\stackrel{5}{4}$ & 일 \\
\hline $\begin{array}{l}\text { Vegrtable Food, contlnued } \\
\text { Nuts- }\end{array}$ & $\begin{array}{l}\text { Per } \\
\text { cent }\end{array}$ & $\begin{array}{l}\text { Per } \\
\text { cent }\end{array}$ & $\begin{array}{l}\text { Per } \\
\text { cent }\end{array}$ & $\begin{array}{l}\text { Per } \\
\text { cent }\end{array}$ & $\begin{array}{l}\text { Per } \\
\text { cent }\end{array}$ & $\begin{array}{l}\text { Per } \\
\text { ct. }\end{array}$ & $\begin{array}{r}\text { Calo } \\
\text { ries }\end{array}$ \\
\hline 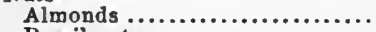 & 45.0 & 2.7 & 11.5 & 30.2 & 9.5 & 1.1 & 1.515 \\
\hline Brazil nuts. & 49.6 & 2.6 & 8.6 & 33.7 & 3.5 & 2.0 & 1,485 \\
\hline Butternuts ............... & 86.4 & .6 & 3.8 & 8.3 & .5 & .4 & 385 \\
\hline Chestnuts, fresh......... & 16.0 & 37.8 & 5.2 & 4.5 & 35.4 & 1.1 & 915 \\
\hline Chestnuts, dried..... & 24.0 & 4.5 & 8.1 & $\mathbf{5 . 3}$ & 56.4 & 1.7 & 1,385 \\
\hline 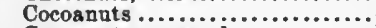 & $* 48.8$ & 7.2 & 2.9 & 25.9 & 14.3 & .9 & 1.295 \\
\hline Cocoannt, prepared..... & & 3.5 & 6.3 & 57.4 & 31.5 & 1.3 & 2,865 \\
\hline Filb & 52.1 & 1.8 & 7.5 & 31.3 & 6.2 & 1.1 & 1,430 \\
\hline Hickory nuts ............. & 62.2 & 1.4 & 5.8 & 25.5 & 4.3 & .8 & 1,145 \\
\hline Pecans, polished.......... & 53.2 & 1.4 & 5.2 & 33.3 & 6.2 & .7 & 1,465 \\
\hline Peannts..... & 24.5 & 6.9 & 19.5 & 29.1 & 18.5 & 1.5 & 1.775 \\
\hline Piñon (Pinus edulis)... & 40.6 & 2.0 & 8.7 & 36.8 & 10.2 & 1.7 & 1,730 \\
\hline Walnnts, black ........ & 74.1 & .6 & 7.2 & 14.6 & 3.0 & .5 & 730 \\
\hline Walnats, English.................. & 58.1 & 1.0 & 6.9 & 26.6 & 6.8 & .6 & 1,250 \\
\hline \multicolumn{8}{|l|}{ Miscellaneous - } \\
\hline Chocolate..... & & 5.9 & 12.9 & 48.7 & 30.3 & 2.2 & 5,625 \\
\hline Cocoa, powdered..................... & & 4.6 & 21.6 & 28.9 & 37.7 & 7.2 & 2,160 \\
\hline Cereal coffee, infusion ( 1 part & & & & & & & \\
\hline & & 98.2 & .2 & & 1.4 & .2 & 30 \\
\hline
\end{tabular}

* Milk and shell.

tThe average of five analyses of cereal coffee grain is: Water 6.2 , protein 13.3, fat 3.4, carbohydrates 72.6 . and ash 4.5 per cent. Only a portion of the nutrients, however, enter into the infusion. The average in the table repre. sents the available nutrients in the beverage. Infusion of gennine coffee and of tea like the above contain practically no nutrients.

Many important developments have been made in the study of foods during the life of the New Earth; for, while these foods in the main existed before this period began, they seem, by the individuality which has been given them under the new order, to belong significantly to the present. One of the most important developments has been in showing 


\section{THE NEW EARTH}

the folly of waste,- - not only waste in discarding from the table foods which could be used in other form, and waste in cooking more food than the eater needs, but waste in the foods themselves as they go about their service to the body. Unquestionably, one of the most fruitful causes of indigestion and all the long train of terrors that follow in its wake is the eating of unnecessary foods, those which only burden and clog the system. The new knowledge has taught how to avoid this by selecting such foods as will preserve the proper balance. This can be accomplished without in any sense starving the body or robbing the taste of any of its delights. Meat, eggs, fish, fresh vegetables, milk, and fruits contain, to quote again Professor Atwater, the most refuse and water; protein is most abundant in the animal foods and in the legumes, as peas and beans, and occurs in considerable quantities in the cereals; fats occur principally in the animal foods, while carbohydrates are found almost exclusively in the vegetable products and milk.

'The work of investigating foods has progressed beyond the importance of the food as 
food, into the realm of the influence of food upon the health, mental as well as physical.

Since the general period of which mention has frequently been made, some very interesting and valuable data have been accumulated as to the length of time required for the digestion of certain foods in the stomach of a man in health, thus leading to important conclusions as to the care of the man when ill. While much of the digestion takes place after the food has passed into the intestines, it is important to be able to determine the time it remains in the stomach. Fluids leave the stomach much more quickly than solids,water, or other common beverages, in an hour and a half, boiled milk in about two hours, while hot drinks do not leave any more quickly than cold ones. It took from two to three hours each, as shown in an extensive series of tests, for ten moderate-sized oysters, two eggs - raw, poached, or in an omelet-seven ounces of sweetbreads, seven ounces of white fish, or three and one-half ounces of white bread, cauliflower, or cherries, to pass out of the stomach. It took from three to four hours each for eight ounces of chicken, nine ounces 


\section{THE NEW EARTH}

of lean beef, six ounces of boiled ham, three and one-half ounces roast veal or beefsteak, five and one-third ounces of coarse bread, boiled rice, carrots, spinach, radish, or apple; from four to five hours for nine ounces of smoked tongue, three and one-half ounces of smoked beef, nine ounces of roast goose, five and one-third ounces string beans, or seven ounces of pea porridge. It appears from the investigations that the materials most readily digested are those of soft consistency. The white meat of chickens left the stomach more quickly than the dark meat, or the red meats of other animals. Fresh fish was more easily digested than meats.

Another important field of development lies in ascertaining the amount of the foods which, under normal conditions, the body assimilates for its own uses. It has been shown by recent investigations that, in an ordinary mixed diet, about ninety-two per cent of the protein, ninety-five of the fats, and ninety-seven of the carbohydrates are retained in the body. There is considerable difference between the amount retained from animal foods and that retained from vegetables. About ninety-seven per cent 


\section{THE FOODS OF THE NEW EARTH}

of the protein, ninety-five of the fats, and ninety-eight of the carbohydrates in the animal foods are digested. In the vegetable foods the amount runs: eighty-four per cent of protein, ninety of fats, and ninety-seven of the carbohydrates. In connection with the former tabular statement as to the composition of foods, the following table from the same bulletin as to the amount which the body retains for its uses will be of interest. It is the result of much experimenting:

\begin{tabular}{|c|c|c|c|c|c|c|}
\hline \multirow[b]{2}{*}{ KIND OF FOOD } & \multicolumn{2}{|c|}{ Protein } & \multicolumn{2}{|c|}{ Fat } & \multicolumn{2}{|c|}{ Carbohydrates } \\
\hline & $\begin{array}{c}\text { Digesti- } \\
\text { bility }\end{array}$ & $\begin{array}{c}\text { Fuel } \\
\text { value } \\
\text { per lb. }\end{array}$ & $\begin{array}{c}\text { Digesti- } \\
\text { bility }\end{array}$ & $\begin{array}{l}\text { Fuel } \\
\text { vaiue } \\
\text { per lb. }\end{array}$ & $\begin{array}{c}\text { Digesti- } \\
\text { bility }\end{array}$ & $\begin{array}{c}\text { Fuel } \\
\text { value } \\
\text { per lb. }\end{array}$ \\
\hline & $\begin{array}{l}\text { Per } \\
\text { cent }\end{array}$ & $\begin{array}{c}\text { Calo- } \\
\text { ries }\end{array}$ & $\begin{array}{c}\text { Per } \\
\text { cent }\end{array}$ & $\begin{array}{c}\text { Calo- } \\
\text { ries }\end{array}$ & $\begin{array}{c}\text { Per } \\
\text { cent }\end{array}$ & $\begin{array}{c}\text { Calo- } \\
\text { ries }\end{array}$ \\
\hline Meats and fisb............. & 97 & 1.940 & 95 & 4,040 & 98 & 1,730 \\
\hline Eggs................. & 97 & 1,980 & 95 & 4,090 & 98 & 1.730 \\
\hline Dairy products ............. & 97 & 1,940 & 95 & 3,990 & 98 & 1,730 \\
\hline Animal food (of mixed diet) & 97 & 1,940 & 95 & 4,050 & 98 & 1,730 \\
\hline Cereals ........................... & 85 & 1,750 & 90 & 3,800 & 98 & 1,860 \\
\hline Legumes (dried) .............. & 78 & 1,570 & 90 & 3,800 & 97 & 1,840 \\
\hline Sugars..................... & .... & .... & $\cdots$ & .... & 98 & 1,750 \\
\hline Starches................... & $\dddot{8}$ & 1 & $\dddot{90}$ & $\dddot{3} \ddot{8}$ & 98 & 1,860 \\
\hline Vegetables.................... & 83 & 1,410 & 90 & 3,800 & 95 & 1,800 \\
\hline Fruits $\ldots \ldots \ldots \ldots \ldots \ldots$ & 85 & 1,520 & 90 & 3,800 & 90 & 1,630 \\
\hline $\begin{array}{l}\text { Veqetable foods (of mixed } \\
\text { diet) } \ldots \ldots\end{array}$ & 84 & 1,840 & 90 & 3,800 & 97 & 1,820 \\
\hline Total food (ô mixed diet). & 92 & 1,820 & 95 & 4,050 & 97 & 1,820 \\
\hline
\end{tabular}

Perhaps in no way under the old régime was food so injured for the purpose to which it should be put as in the cooking of it. Even today it will not be so very difficult, in certain 


\section{THE NEW EARTH}

regions of the country, to find people who have the very best of raw material on which to work, but who cook their foods so wretchedly, - I had almost said so diabolically, - that it is almost worse than not to have been cooked at all. The investigations which have been under way in the general subject of foods have not ignored the all-important question of the cooking of the food itself. The heat changes the mechanical condition of food so that it may the more easily be acted upon, and in the cooking the actual character of the food is so changed that it can be more easily chewed and digested. Unquestionably, the appearance of the food upon the table, and the general appearance of the table itself and its accessories, have a marked influence upon digestion. If the stomach blushes at the sight of food, it is a pretty sure sign that the food is what it ought to be, at least as far as outward appearance goes; and it is precisely this which happens when the food is appetizing and nutritious,- the blood rushes pleasantly to the stomach to assist in the digestion, while under untoward conditions it remains longer away. All through the country, the educational in- 
stitutions which come nearest to the life of the farm are teaching the young women who come up from the farms how they may prepare foods in the most attractive manner, at the same time making the foods more digestible and hence more strengthening. The United States Department of Agriculture has issued a number of bulletins bearing upon the question of dietaries, which may be obtained from that department, showing how the food of a family, for instance, may be prepared in accordance with the facts developed in the food investigations which have been carried on in recent years in different parts of the world.

Should one wish to find out whether the family is being supplied with just the right amount of food, and just the proper kind, an interesting and profitable home test may be made, based upon the tabular statements before given. Elaborate preparations or paraphernalia are not necessary. All the foods coming into the house should carefully be weighed. Say ten days is set apart for the test. Beginning with the initial day, the amount of food supply on hand being known, the food should carefully be weighed out, so that the amount used 
during the test may be determined. The first table before given shows the quantity of nutrients in practically all foods that would be used in an ordinary family, so that one may know precisely how much nourishment and how much waste there is in the foods which are being eaten during the test. After prolonged investigation by many different men, it has been proven that, under normal conditions, a man at hard muscular work requires one and two-tenths the food of a man at moderately active muscular work; a man with light muscular work and a boy fifteen to sixteen years old, nine-tenths the food of a man at moderately muscular work. Men in sedentary occupations and women at moderately active work, boys from thirteen to fourteen and girls fifteen to sixteen, need eight-tenths the food of the man at moderately active muscular work. Women at light work, boys of twelve, and girls thirteen to fourteen require seven-tenths, boys ten to eleven and girls ten to twelve, sixtenths, and children from six to nine years, five-tenths as much as the man at moderately active muscular work.

As to the actual amount of food each person 276 



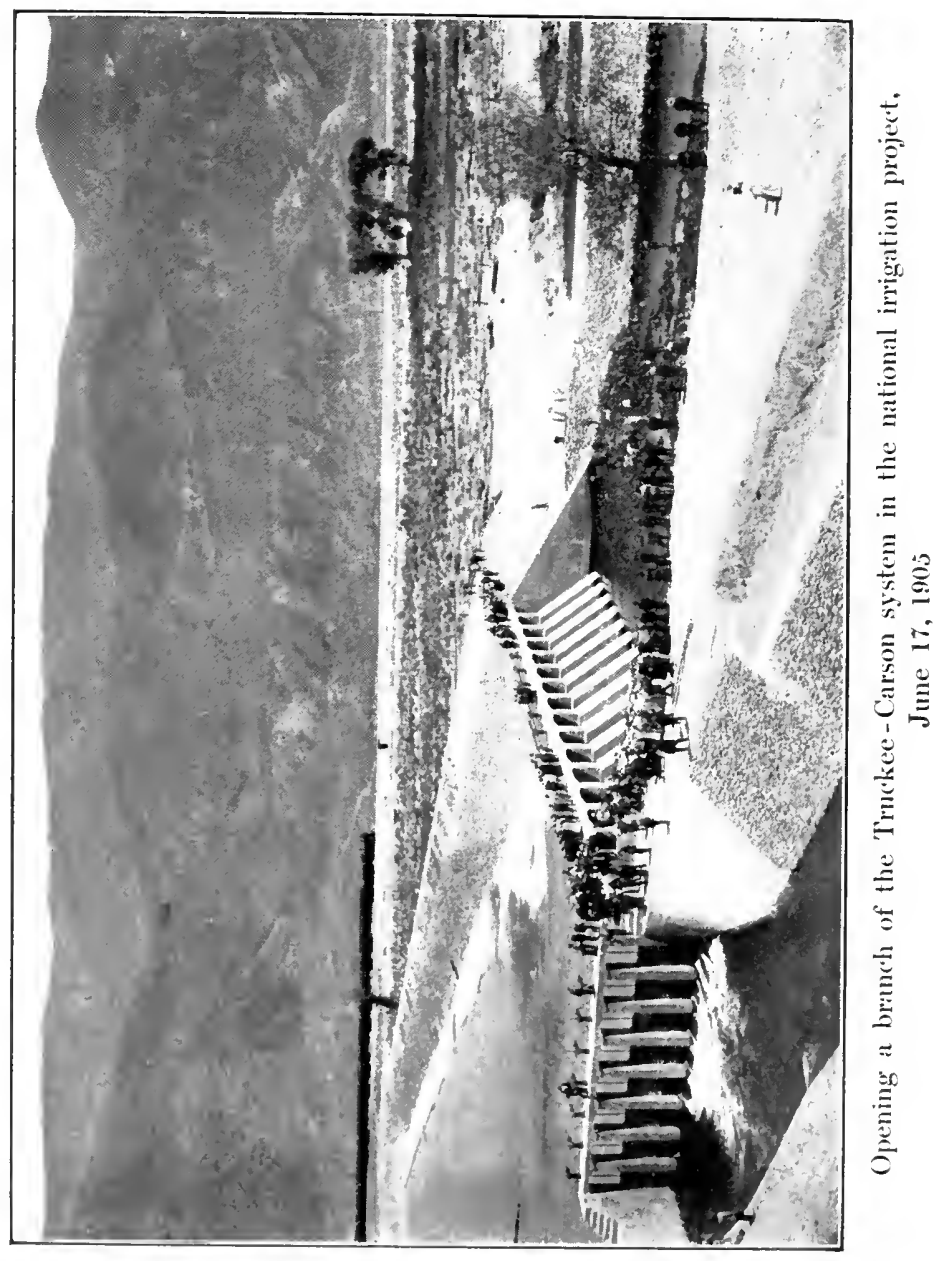




\section{THE FOODS OF THE NEW EARTH}

will eat, each one must be the judge, but the foregoing will give a relative basis upon which to work, while the tabular statement will show the composition of the material which is being used. I think the consensus of opinion on the part of those who are giving so much valuable time to a study of this subject is that nearly all men eat too much. It is, by no means, the amount one eats or the amount of nutriment in the foods themselves, necessarily, which determines the food value, but the amount that is assimilated; and there can be no doubt that sufficient can be assimilated for all bodily needs from considerably less food than most people eat.

We may not pass from this question of the foods of the New Earth without noting, as an illustration of the comprehensiveness of the work being done by scientific men, a series of tests carried on by Professor Snyder, of the University of Minnesota, in determining the value of sugar as a food. Three men were carried through two feeding tests, - one of the tests with no sugar in the meals, one with sugar. Every possible care was taken that the actual influence exerted upon the system by 


\section{THE NEW EARTH}

the sugar should be ascertained. Each man ate each day a quarter of a pound of oatmeal, a quarter of a pound of cheese, three-quarters of a pound of bread, three ounces of butter, two ounces of raspberries, one pint of milk, and two eggs. On the days when the sugar was eaten, - the other foods being identical in each case,- each man was given five ounces of granulated sugar testing ninety-nine and two-tenths per cent pure.

The amount of waste was accurately determined so that the precise food values were ascertained. It was shown in the tests that there was absolutely no digestive influence of the sugar upon the other foods; that there was no waste in the sugar to amount to anything, ninety-eight and nine-tenths of the total energy of the sugar being available for the body; that the amount of the protein material,- the strength-producing portions of the food-retained in the body was greater when the sugar was fed, because the sugar helped provide the fuel for the body and thus there was less demand made upon the protein material from the other foods. It was clearly demonstrated in the tests that sugar is too 


\section{THE FOODS OF THE NEW EARTH}

often considered merely as a condiment to give taste and flavor to foods, while in reality its main function is that of nutrition. It was shown that sugar as a heat- and energy-producing factor was not only fully equal to starch, but that it is more readily absorbed into the system than starch. The fact that confectioners notice a far larger consumption of candies in winter than in summer goes to show the demand of nature for the heat which the sugar in the candies provides.

It has been proven, also, that sugar is a very powerful stimulant for men in the midst of exhausting physical strain. The sugar is so quickly and thoroughly assimilated, and has so marked an effect upon the energy, that when an ounce of it is fed to a man whose strength is taxed to the utmost the result is remarkable -it enables the man to pull through the crisis. In one case a man in the midst of tremendous toil and nearing exhaustion was given a sweettasting substance so near like sugar he did not know the difference. It had no effect upon him whatever, but the moment the sugar was substituted the needed additional strength was his.

This single illustration, chosen from very 


\section{THE NEW EARTH}

many, will indicate how widespread and thorough is the study which is being given to foods, the sole object being to add to the happiness and health of man. And there can be no reasonable doubt that along with an improvement in the dietary goes better health and a prolongation of the span of life.

But, as the scientific men of the New Earth have turned their attention more and more to the study of foods, unscrupulous men have exercised their ingenuity more and more in the way of counterfeiting and adulterating foods. And it is very interesting to note that the providing of means for the punishment of men engaged in such nefarious practices began about the same time that this revival in knowledge in the affairs of the earth began. In 1861, the national government initiated such legislation, though it was then in the nature of internal revenue action, placing a tax upon goods which were not being sold for what they really were. A few years later, state by state, the commonwealths took up the subject, made investigations, found frauds in almost every sort of food in the market, and began a vigorous crusade against the offenders. In the last 


\section{THE FOODS OF THE NEW EARTH}

generation the activity in this direction has been greater than perhaps in all the previous history of the country put together. It is another curious confirmation of the fact that this period of which we write is one of the marked periods in our history. While evasions of the law yet are known, and while much depends upon the strictness of the administration, the laws already enacted are going far toward overcoming this dangerous form of criminality. Recently the national government has taken up the subject of food preservatives, and this illustrates the scope of this line of work. 'The Bureau of Chemistry of the Department of Agriculture undertook the determination of the effect of borax and boric acid upon foods when used as preservatives. There were three ways in which the test could be made,-by artificial digestion in the laboratory, by experiments conducted upon lower animals, and by experiments upon human beings. 'This latter test would obviously be the most satisfactory, but no one could be compelled to subsist upon foods known to have been treated by preservatives which might be injurious. Volunteers came forward, however, and twelve 


\section{THE NEW EARTH}

men were selected. For a long time these men were fed with foods treated as the foods offered for sale were treated, with the result that the preservatives were found injurious, both when used in very small quantities for a long time, and when used in large quantities for a short time, creating disturbances of the appetite and of the digestion and impairing the health.

The unselfishness of the men who were willing to submit themselves to the test for the good of their fellows was not only a refutation of the charge that there is a growing decadence of the true American spirit, but a proof that the finest chivalry flowers even in the midst of much crass selfishness.

From every point of view the foods of the New Earth are being studied and improved; they are being steadily fitted for better service for man. A wider knowledge than ever before as to the nature and value of these foods is accumulating day by day, for the benefit of those who have long been in darkness. Those who should know the character of foods most intimately of all but who have been of all most ignorant,- - the ones who provide the raw 


\section{THE FOODS OF THE NEW EARTH}

material from which these foods are prepared for man,-are in these later days being provided with avenues of information along which they may travel to health. Among all the activities of the New Earth none is more important, none is entered in upon with greater zest by the practical men of science, none brings a richer measure of profit and satisfaction. It is one of the significant movements of the generation-this crusade, if you will, against bad foods and for good foods. It is a most cheering thing that people are learning that it pays to be well and happy, and that one of the ways to be well and happy is to eat better foods,- not necessarily higher-priced ones, but better ones; to have these foods prepared in an attractive manner, and to bear in mind that the stomach is not a pack-horse to be loaded and goaded but one of the most delicate, precious and powerful organs of man's body. Without its sympathetic and healthy aid, man swiftly passes into a region which the dyspeptic fitly describes as a hell upon earth; with its aid man rises to his highest estate, physical, mental,--indeed, in a deep, true sense, moral and spiritual. The foods of a nation, 
their preparation, qualities and purity, largely determine the character and fiber of the people; the wider and deeper man's knowledge of them, the nearer he may approach the ideal.

The study of foods and their values need by no means be restricted to those who approach from the scientific point of view. Nor need one become one of those enthusiasts who continually do dwell on the border lines of the cranks. The opportunity is now open for any one, in town or country, who realizes that he has been cheated a good part of his life out of his fair share of service from the foods he eats, to determine for himself where the trouble lies;-then to remedy the difficulty in a simple, but permanent manner. The present generation, and still more, the generations to be born, owe a deep debt of gratitude to the practical men of science who have simplified, and at the same time enriched, the dietary of the world. 


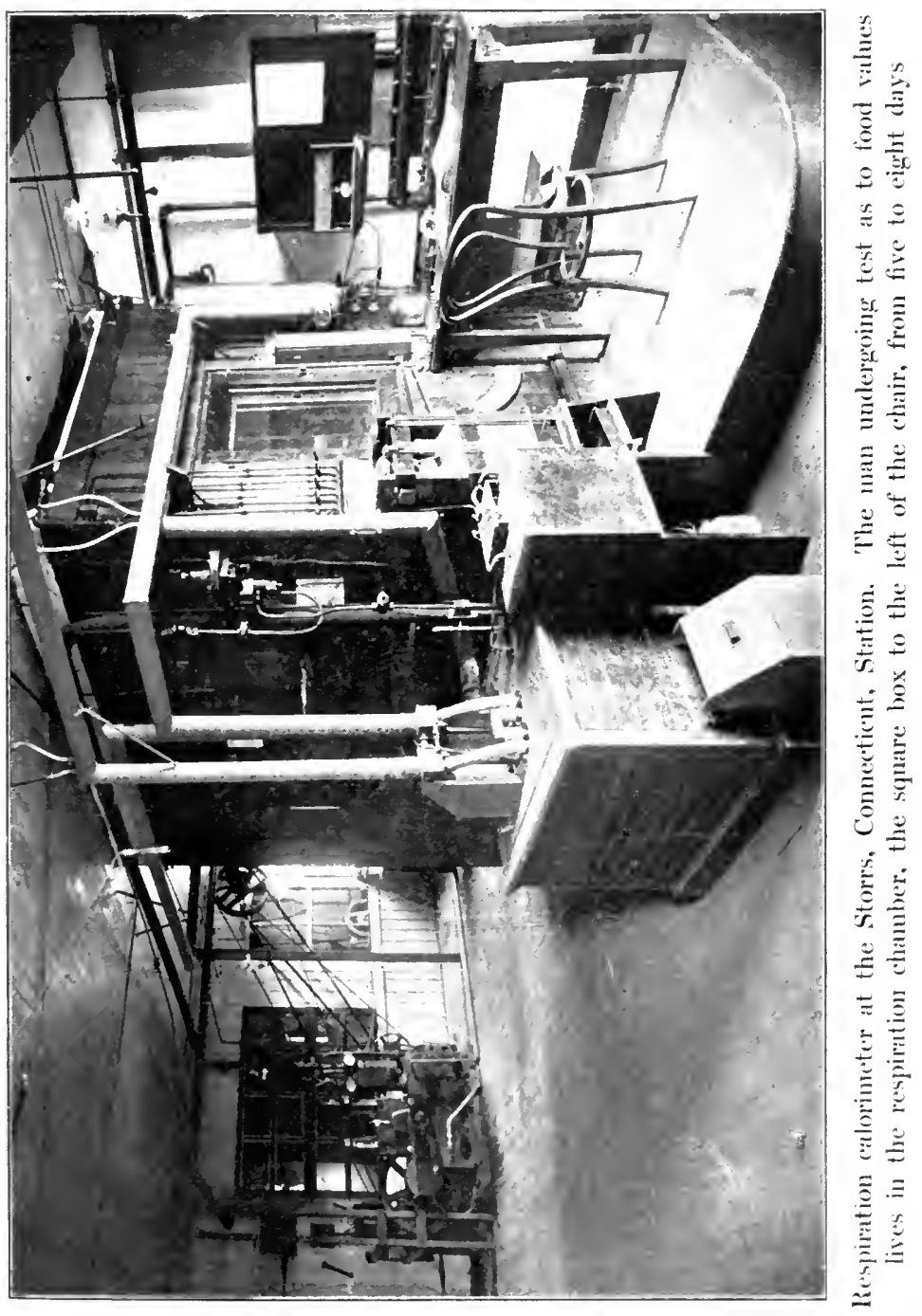





\section{CHAP'TER XV}

\section{COÖPERATION}

THE desire for betterment of conditions 1 has been the moving factor in the advance of the New Earth. On the part of the men of practical science, to whom belongs so large a measure of credit for the development of the New Earth, the effort put forth has been, primarily, for others. On the part of those who till the earth and live upon its bounty, the effort has been indeed for self, but in no wise has selfishness been at the bottom. The advance has been merely the working out of the underlying principles of self-protection, or, better put, a high and noble care for one's own. Naturally, along with the progress of the new period, has come to those who gain their livelihood from the earth, not only a new sense of the dignity and importance of their calling, but a new sense of power. 'This has manifested itself in a variety of ways, some of them inoperative through lack of united effort, 


\section{THE NEW EARTH}

some of them one-sided, but all of them on fire with independence. I think it is quite impossible for one who has been reared in the city life, particularly the life of large eastern cities, where the people, through possibly several centuries, have settled down into conservative ways distinctly their own, to appreciate the situation in the farming regions of the West, when the West was first emerging from the period of the pioneers. All conditions were unsettled. Everything was in a formative shape. Very large numbers of farmers were distressingly poor, as must ever be the case when new regions are being brought under cultivation. They were heavily in debt. They found it exceeding hard to meet their obligations. They were individuals, not corporations.

About the time that the New Earth period began, there came across the sea more and more frequent tales of the success which had been achieved through a union of forces by the weavers of Rochdale, a band of men who were in sorer straits than ever the American farmers had been. These weavers, a generation before the New Earth began, living in the 


\section{O ÖPERATION}

English manufacturing town of Rochdale, not far from the city of Manchester, were in dire poverty. They could not make both ends meet. They sought in vain for betterment. One day twenty-seven of them banded themselves together. They established the first coöperative society - in the modern meaning of the term-in the world. It was not so much a blow at capital as it was a protest against poverty. In a House of Commons debate, just before the society was established, it was shown that there were over two thousand people in Rochdale living on forty-six cents a week, or less,-indeed, in some instances, as low as twelve cents per week, many families having but a single blanket, and some with chaff beds and no coverings at all. It was a case of life or death, and the weavers chose life. 'They transacted business, the first year they set up for themselves, amounting to twenty-eight pounds, - in round figures, one hundred and forty dollars. I visited Rochdale in 1899 and found the business of the first coöperative organization in the world advanced from one hundred and forty dollars a year to over one million, five hundred thousand dollars a year, 


\section{THE NEW EARTH}

with profits for that current year amounting to two hundred and forty thousand dollars. Prosperity was to be seen on every hand. Coöperation had transformed the people, had lifted them from debt, had given them comfortable homes, had provided opportunities for cultivation, had made self-reliant men out of worse than slaves, had transmuted squalor into comfort.

Slowly the idea spread and took root in other lands. In 1905 there were about fifty thousand coöperative societies in Europe outside of Great Britain, more than eight hundred thousand members of the agricultural coöperative societies in France alone. There are in England, as an outgrowth of the Pioneer society of Rochdale, nearly two thousand societies with more than two million members and nearly one hundred and fifty million dollars in capital. I stood in front of the somber building in Toad Lane, Rochdale, where the handful of weavers met that dull November day in 1844, to free themselves from poverty. It was a building long given over to other occupations, unattractive and down-atthe-heel, but it should be forever preserved as 


\section{COÖPER A TION}

the birthplace of one of the greatest of all movements inaugurated in our era.

Had the condition of the western farmers been worse than it was, more nearly approaching the condition of the weavers of Rochdale, the American progress in coöperation would have been more rapid; for when relief must come through effort, the deeper the misery, sometimes, the greater effort demanded, and greater the relief when it comes. Mention has been made in another chapter of the success of the Iowa farmers who went into business for themselves in order to get fair treatment from unfair capital. While their effort, so signally successful, was not in a sense coöperative, the principle that underlies coöperation which finds its expression in what we call self-preservation, was at the basis of their effort. Coöperation had been tried in a number of places throughout the United States as the news of the success of the Rochdale movement came over seas. About the begining of the period of the New Earth, a number of farmers gathered in the town of Hatfield, Massachusetts, and established a coöperative dairy which soon became successful and proved 


\section{THE NEW EARTH}

of large economic importance. As early as 1860, associated dairying was followed by New York farmers, much the same in spirit as actual coöperation. In other states coöperation in one form or another was tried, but it was not until the farmers of the central West, learning from their eastern friends and hearing the call of Rochdale, began coöperation, that it can be said to have attained anything like large proportions. Many of the western farmers were the sons of the pioneers who had opened the country in the midst of great hardships. They were, in many cases, still living under the shadow of old debts. Frequently, through lack of knowledge, they had worn out their soils by too steady cropping of wheat, and were learning by dear experience that they must diversify their farming or sink still deeper in the slough of debt. It was the day of dependence upon eastern capital, and, however great the real obligations which farmers owed to others for starting them in their life through loans from the East, which not infrequently were larger in their risks than even the farmers themselves appreciated, still the debts were there and must be met. 


\section{O ÖPERATION}

A few years after the beginning of coöperative dairying at Hatfield, some such sight as this could be witnessed of an evening in some western farming community in the schoolhouse where their educational interests centered, or perhaps on a Saturday afternoon in the town-hall of the near-by village:

From thirty to fifty farmers would be gathered together to discuss coöperation, or, rather, to enter into coöperation, for discussion had ended and there was light ahead. An agreement would be entered into providing, among other things, for a constitution, customary officers, and so on, and also, that each farmer should pledge a certain number of cows whose milk he agreed to bring regularly to the creamery, to be established. A fund of from two to three thousand dollars would be provided for the building and equipment of the creamery, or, in some cases, of a cheese factory. This would be located on the railroad and nearest the center of population of the farmers uniting. Then the milk would be brought in from the herds of these farmers to this common center, to be separated and turned into butter. In order that perfect fairness to all 
might prevail, the milk was credited up to each member not by amount but by quality,the Babcock milk test enabling the manager of the creamery to determine just how much butter-fat there was in each farmer's supply. Usually a sinking-fund was provided for contingencies, including repairs and the like, usually five cents for every hundred pounds of milk taken in. Should there be a dishonest farmer in the lot, guilty of watering his milk, or otherwise adulterating it, provision was made for a fine of ten dollars for the first offense, twenty-five dollars for the second, and expulsion for the third. At regular, and frequent intervals the farmers received their pay for the milk turned in, so that there was no danger of the accumulation of any tempting surplus. Having complete control of the creamery themselves, fraud was practically an impossibility.

The growth of the movement was rapid. At the end of the first ten years, about the year 1898, the business of the coöperative creameries in the central West, inclusive of such states as Minnesota, Wisconsin, Iowa and Illinois, the ones most largely interested in the 



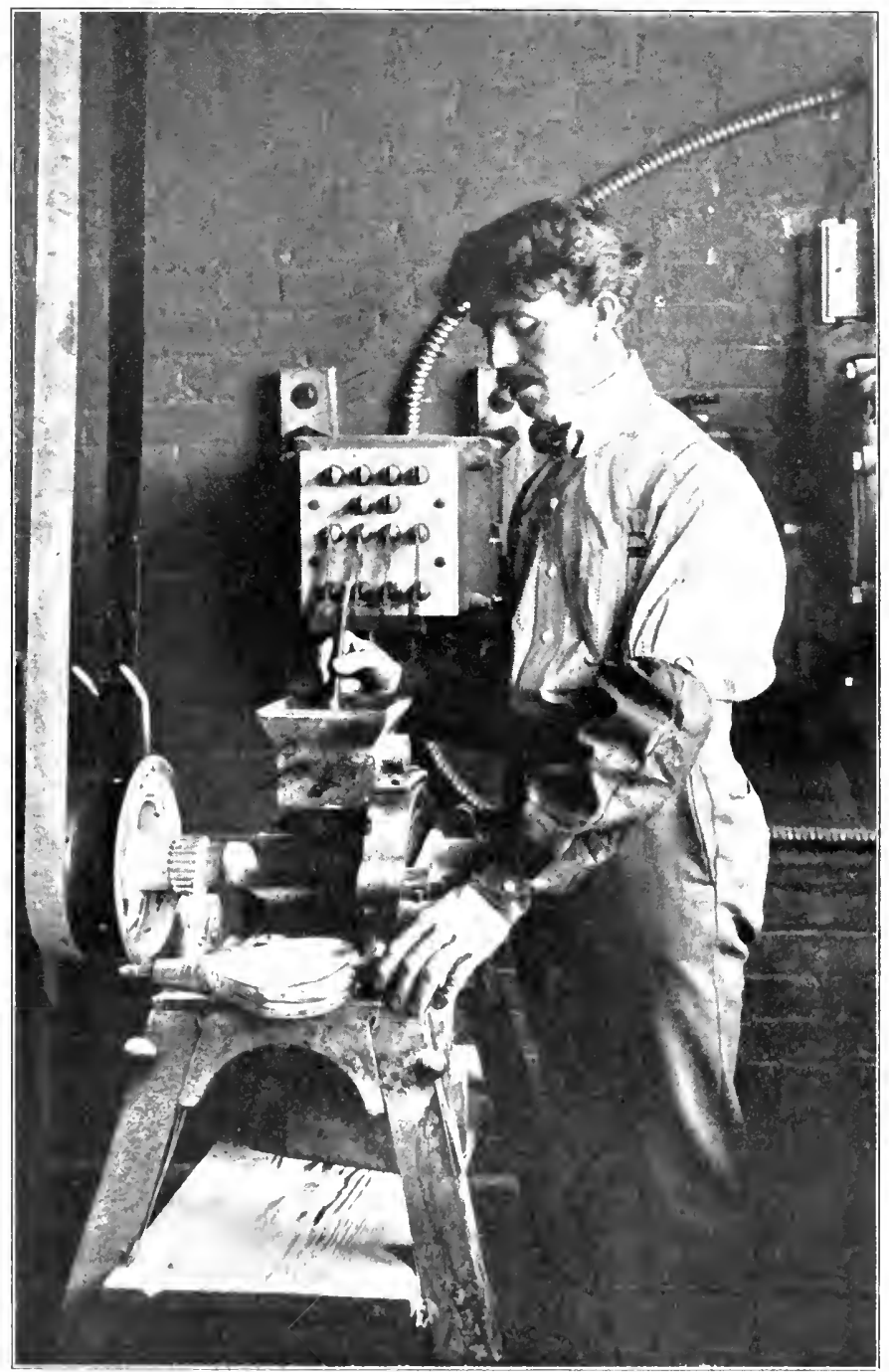

Grindinge com under test at the Illinois station preparatory to laboratory teats lo show the exaret toos value of the corm 
movement, amounted to about thirty millions of dollars per year. 'The practicability of coöperation in the United States was thus established,- - no matter what might be the outcome of adverse combinations, or what the influences brought to bear by unfair capital. It was a clear, positive illustration of the fact that the underlying principles of coöperation are sound. A concrete illustration was shown in the case of one county in the state of Minnesota. This county was exclusively agricultural. 'There was little or no manufacturing in its borders upon which to depend. For years the farmers had been pushing the wheat lands beyond the limit of production, and Nature's slow but unanswerable protest had at last been entered. The farmers turned to coöperative dairying. Creameries for butter manufacture were established, some twentynine in all. 'There were nearly three thousand members, or stockholders. In the year in which the first creamery was established there were twenty-four mortgage foreclosures; the number four years later had fallen to one; in the next year there were none. 'Ten years after the establishment of the first creamery 


\section{THE NEW EARTH}

the delinquent tax list was only one-fifth as large as in the year it was founded. The average deposits of the farmers in one town in the county, the year of the first creamery, were fifty-six thousand dollars; the average ten years later, with the creameries in full running order, was three hundred and twenty thousand dollars; and this does not include the deposits of the creameries themselves, some sixty thousand dollars additional. Farm lands increased in the ten years from ten to thirty dollars per acre to twenty-five to sixty dollars per acre.

The illustration is worthy of close study. It shows in concrete form what may actually be accomplished in coöperation under normal conditions in America.

But it must be noted, in passing, that coöperation in the United States and coöperation in Great Britain, for example, do not proceed upon parallel lines. In essence the spirit is the same, but in practice the English system is much broader. In England coöperation has widened until it takes in practically every agricultural, manufacturing and general trade interest. It extends to the cities where great establishments are founded, carrying on an 
enormous volume of retail and wholesale trade. In America, where greater freedom in many ways prevails, where the men who are most interested in such lines - as the farmers of the New Earth, for example - are broader in their outlook and better fitted by their freer life for service, the possibilities are even greater than in Great Britain. The extension of coöperation beyond the coöperative dairying, which has been so successful, lies wholly with the farmers. 'There are obstacles, to be sure, but they are wholly different from the obstacles which have been in the way of the success of other farmers' organizations, and far easier to surmount.

No doubt certain selfish interests will openly or covertly attack any movement of this kind. Concentrated capital in the hands of unfair men will as quickly seek to destroy the life of a coöperative creamery as to crush a dangerous rival railroad. Attempts may be made so to combine corporate interests of various kinds as either to push the coöperators to the wall, so that they will be obliged to sell out at a sacrifice to save themselves from ruin, or to tempt them to abandon their position by the 
promise of larger financial returns in combination, even if independence be extinguished and competition throttled. There is, on the part of modern capital in the hands of dishonest men, an apparent standard of success which is measured by the power to crush or corrupt. 'The coöperative creamery movement makes no fight upon capital as such, but welcomes its coming as a factor in the development of the country; indeed, much as in the case of the Iowa farmers, the creamery men are capitalists themselves in a small way, managing their affairs with the same sagacity and honesty that mark the investments of honestly administered wealth the world over.

The closer one studies coöperation in England, and particularly in Rochdale, the home and the fountainhead, the clearer its power comes into view. Certainly, I could not have had a more interesting-object lesson in the scope and sweep of modern coöperation than that which was afforded in the fine, wellselected library of the Pioneer society in Rochdale, twenty thousand volumes, covering every department of literary activity, liberally patronized by the members of the society. 'Through- 
out the city are twenty-one branch libraries where the coöperatives may obtain books without going to the down-town center. In the coöperative stores throughout the city were reading-rooms, or news-rooms, in addition to the large, airy reading-room in the library proper. The possibilities of coöperation in the United States, particularly among those who are most directly interested in the activities of the New Earth, are essentially limitless. 'The extension of the system until it includes every department of farm, dairy, range, orchard and town life would be not only far easier of accomplishment in America than in Great Britain, but the results, large as they are in the latter country, must be vastly increased in a country so peculiarly fitted for coöperative endeavor as the United States. 


\section{CHAP'TER XVI}

THE SELLING OF THE SURPLUS

NE lovely September day, when the fogs of London were noteworthy through their absence, I was wandering along King's Road through the heart of historic Chelsea, when it occurred to me to find out where the fine-looking beef came from which I had noticed hanging in the stalls along the way. King's Road is a crowded retail street of rather small, but well-to-do, business houses. In an hour or so I called in at a dozen markets. In each instance, I asked the dealer what kind of beef he was selling, and, looking sharply at me, he answered with more or less trace of dialect, according as he was provincial or city bred: "Prime Scottish, sir; the best in the world."

Or, it might be, this remark was varied now and then by the statement that it was the finest English beef on the market. In every instance but two, however, after I had explained that I was an American, and was 


\section{THE SELLING OF THE SURPLUS}

merely seeking information, the dealer told me, quite confidentially, that the best beef on his hooks came from the United States. He did not say it out loud in Iondon, so stiff was the prejudice against American beef.

I kept on in my long walk down Victoria street, past noble old Westminster, and out through Trafalgar Square, until at last I was one of the thousands passing along the historic Strand toward Ludgate Hill, where the Strand has melted into Fleet street. But I turned off to the left before I reached St. Paul's, and made my way to Smithfield, the great meat-market of London, where enormous supplies are daily sold to the retailers of the city. Here I met the representative of a large American packing-house. I told him of my experience along King's Road. He laughed and related this incident:

But a few days before, he had received a telephone message from one of the fashionable residences of the $W$ est End. It was from the woman who reigned over the affairs of the household. She had entrusted no one else with the ordering of some beef for a dinner, to be given to a company of her countrymen. She 
asked the representative of the American firm if he could send her some extra-fine Scottish beef-no other would do. He hesitated a moment, telling her, of course, how excellent was the last American importation, a lot that was particularly desirable, both in flavor and curing. She replied, animatedly, that she was delighted to hear it, but she must have the Scottish, for none of her guests cared a fig for American beef. Could he get her some, extra fine? The American dealer smiled, and answered that he thought he understood her, and that he would see that she had what she wished.

"And, of course, she got it," he added, laughingly, "and, of course, she knew where it was grown and cured, and, of course, her guests praised the beef to the skies, so utterly unlike the horrid stuff the Americans send over!"

So it has gone in past days, not only in England, but on the continent, and not only in beef, but in other products of the earth, which we are ready to barter abroad. Not infrequently, as in the case of fruits, for example, it has been the fault of the American producer that his wares were not in demand a second 


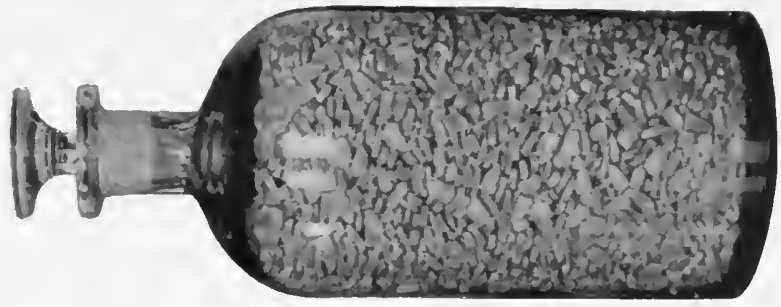

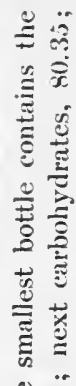

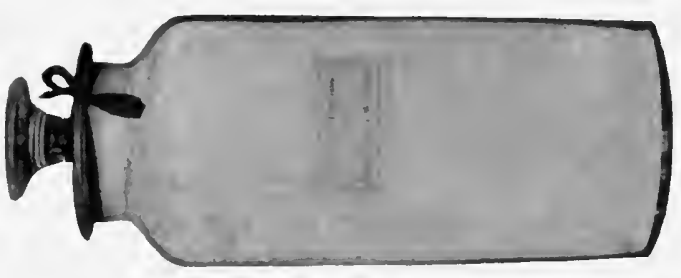

E

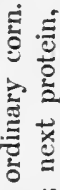

岁

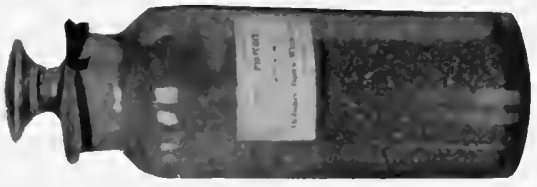

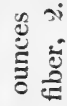

范

¿...

$+8$

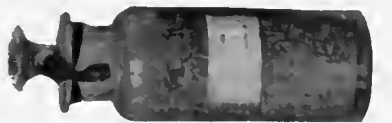

ป -

吾

ฏ

蓠

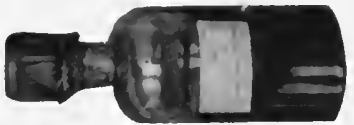

$\cong \ddot{\Xi}$

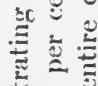

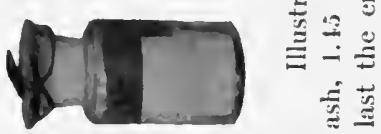



time, and all because he did not appreciate the fact that he must send good goods attractively packed. There have been jealousies to fight and prejudices to sweep away. The swiftest way to accomplish these ends is to raise the standard of the product. 'Take, for another example, corn. During the year 1905, leading importers in European countries entered vigorous protests against the condition of the corn received by them from the United States. Apropos is this comment from United States Consul Diederich, of Bremen, Germany:

"For years, complaints on the part of importers of American corn, or maize, have been loud and numerous. The certificates covering these shipments, in many instances, proved to be utterly false, the grain, upon arrival here, frequently being in a wretched condition damp and overheated, moldy and filthy. As the firms to whom these shipments were consigned could find no redress anywhere, their losses were very heavy. Time and again, American consuls have sent in reports on this subject, warning our people interested in the export of this particular grain not to ship any but corn of prime quality; but to the present 


\section{THE NEW EARTH}

time all efforts in this direction have been of no avail.

"The dealers of Europe have become weary of protesting any longer against the American way of doing business in this line, and are now ready to join hands in insisting in getting what they bargain and pay for. They demand a square deal, and they ought to get it. In view of the large bumper crop of corn, which is now being garnered in, to be offered for sale in the markets at home and abroad, it would be well for our home dealers to be prepared for a change in the methods of selling American corn to foreigners, and to make up their minds that it will be to their interest to ship no corn across the ocean except it be fully ripe, fully dry, and well protected while in transit."

But, notwithstanding lapses, the extent of our export trade, during the period to which this volume is devoted, shows that our exporters have profited by their experiences. When one considers the elements in this progress, and the sweep of agriculture in America, still far from its meridian, one must be convinced that our sales abroad, enormous as they now seem, 


\section{THE SELLING OF THE SURPLUS}

are meager as compared with what they may become, if we are but wise.

It was at the beginning of this period of the New Earth, that the United States took the first real steps toward the development of foreign trade in the products of orchard, farm and range. No doubt, much of the interest then aroused was due to the prick and stimulus of war ; for, deplore it as we may, war, and especially such a war as that which swept over this country from 1860 to $\mathbf{1 8 6 5}$, is ever a promoter of trade. Six years after the war of the Rebellion closed, in 1870, the agricultural exports of the United States had reached, in round numbers, only three hundred and sixty millions of dollars, and even this sum was eighty per cent (79.9) of our total export trade, showing the commanding position our agriculture had already taken. In 1900, a generation afterward, Great Britain alone bought of us nearly fifty millions of dollars' worth more of these agricultural products than our entire sales in 1870 amounted to, while our total exports of these products in 1900 reached eight hundred and forty-four million, six hundred and sixteen thousand, five hundred and thirty 


\section{THE NEW EARTH}

dollars, exceeding our imports by four hundred and twenty-five millions of dollars. In 1904, the value of our agricultural exports had advanced to, in round numbers, eight hundred and sixty millions of dollars. In the same year, while we produced nearly five billion of dollars' worth of these products, we found we had well on toward a billion dollars' worth to sell abroad. To show how stable is this foreign demand for the products of the New Earth in America, it may be stated that, during the sixteen years ending June 30, 1905, we sold abroad, twelve billions of dollars' worth of these products, while there was a constant and large trade balance in our favor. In 1904, while there was a heavier importation of foreign products of the earth than ever before, mainly coffee, tea, cocoa, chocolate and wool, still the balance of agricultural trade was over three hundred million of dollars in our favor.

Truly we deal with sums of commanding size and influence when we consider what is transpiring in our commercial intercourse with foreign peoples.

Taking 1900, our last national census year, as an example, we find that the ten chief 


\section{THE SELLING OF THE SURPLUS}

export products of the earth, in their order, were: breadstuffs, cotton, meat products, live animals, tobacco, oil-cake and oil-cake meal, vegetable oils, fruit and nuts, dairy products and seeds. 'These ten items made up ninetyfive per cent of the total agricultural exports. Our best customer for the year was Great Britain, who bought to the extent of $\$ 408,000,000$, Germany being second with $\$ 134,000,000$, the Netherlands next with $\$ 52,000,000$, and, following in the order named, France, Belgium, Italy and Japan, with other countries buying from a few hundreds of thousands of dollars' worth each up to several millions of dollars' worth.

It takes long for a nation to work up a foreign trade; it takes tact and patience and a high grade of diplomacy to maintain and extend this trade, once established. It takes long, sometimes, also, for a nation to learn to take advantage of its own facilities. In making a study of transportation via the Mississippi River, for example, one is struck with the wastage of facilities. Here is a natural highway for the products of the earth, much of its course open the entire year to traffic, while 


\section{THE NEW EARTH}

the northern portion is open during the period of the year when traffic of the upper country is heaviest. Immediately tributary to this river are ten states comprising over twentytwo millions of inhabitants and producing every important staple,--the heart of the great Mississippi Valley, one of the richest regions on the globe. At the outlet of the great river lies the Gulf of Mexico, and, beyond, the east and west oceans. When the Isthmian canal is once opened, the market of the Orient will be directly accessible. Note the distances at present from New Orleans to various foreign ports and the distances when this canal shall have been completed: To San Francisco via Cape Horn, 15,052 miles, via the canal, 4,047 miles, distance saved, 11,005 miles; to Acapulco, via Cape Horn, 13,283, via canal, $\mathbf{2 , 4 0 9}$, distance saved, 10,874 miles; to Callao via Cape Horn, 10,901, via canal, 3,000, distance saved, 7,901 miles; to Valparaiso, via Cape Horn, 9,962, via canal, 3,987, distance saved, 5,975 miles. From New Orleans to Yokahama, via the Suez canal is 14,929 miles, via Panama, 9,234, a saving of 5,695 miles; to Hong Kong, via Suez, 13,020 miles, via 306 


\section{'THE SELLING OF THE SURPLUS}

Panama, 11,143, saving 2,877 ; to Sidney, via Cape of Good Hope, 14,624 miles, via Panama, 9,251, a saving of 5,373 miles.

'The railroads crossing the Mississippi Valley and paralleling the great river through nearly all its long course, grow rich in the carriage of the products of this imperial valley, while the river itself, free to all comers, amply able to maintain a traffic far larger than it has ever been called upon to handle, has been neglected through the years.

I have wondered, as I have strolled along the wharves of the city of New Orleans when the cotton was moving, if the time would ever come when the shipping, so meager in comparison with what it should be, would be commensurate with the opportunities. This noble stream, as it flows in resistless power past this southern city,--some eighteen feet, strangely enough, above the level of the streets,- - should be crowded with craft for all ports, foreign and domestic. 'To be sure, many cargoes are coming and going, and the traffic of the port of New Orleans has become larger than that of any other city in America, save New York,--something quite difficult to appre- 
ciate for any one familiar with the shipping of that city, of Boston, Baltimore, and Philadelphia, of Newport News and San Francisco, of Seattle and Tacoma, and Galveston. And yet one cannot fail to see how great has been the neglect of the Mississippi River as a common carrier. There is not, I venture to say, another civilized nation on the globe that would so ignore such an opportunity.

The shipments from the port of $\mathrm{New}$ Orleans are of many kinds, chief among them being cotton, sugar and rice, while grain and flour are exported in large quantities. Some indication of the development possible in the export trade from this port in the products of the earth is seen in the fact that, in 1901, New Orleans exported nearly twenty-five millions of bushels of wheat, as against a little over three million bushels the year before.

Cross the remaining half of the continent from New Orleans and study the export situation in the city of San Francisco. Here, indeed, you will find wholly different conditions, but you will find, as in New Orleans, that the traffic is but in its infancy. A battle royal is on in San Francisco and in the other north 



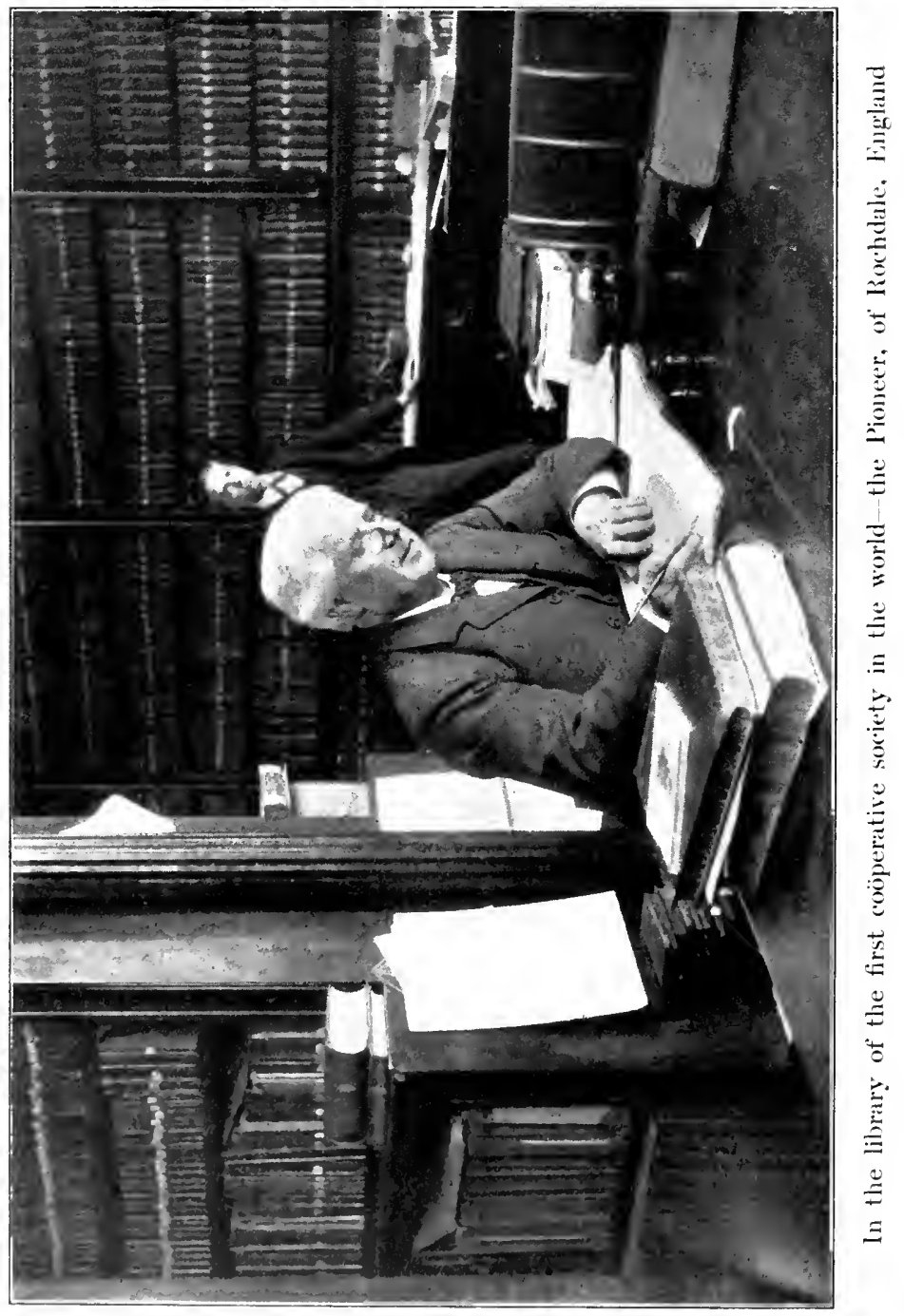




\section{THE SELLING OF THE SURPLUS}

Pacific ports. It will be years, perhaps, before we know who wins. 'The trade of the Orient is the prize fought for. It is a prize worth the winning. Logically tributary to these Pacific coast cities is a traffic estimated, in round numbers, to be about two billions of dollars a year, fully two-thirds being import trade from other countries. The American ports are nearer by thousands of miles than the nearest nation worth considering commercially. In 1904 the United States had less than nine per cent of this trade. 'To make the situation seem all the more incongruous, the United States is not only logically tributary and nearer than any competing nation, but is the best equipped nation on the globe, all things considered, to supply these Orientals with what they must buy away from home. Take it in the line of our agricultural products which are in demand in the Orient. No other nation has so great an arable territory so contiguous to transportation, with a population so well trained in the development of the products of the earth.

The outlook, when Chinese boycotts come, may sometimes be dark. The American, so swift in some ways, has been so slow to see his 


\section{THE NEW EARTH}

eastern opportunity; despite the warnings of our consular representatives, he has been so very slow to adapt his wares to the whims of the Oriental and has been obliged to stand back and see the shrewder European nations capture the prizes; but, nevertheless, there is every reason to look for final victory in the trade battle that is on. Indeed, the exports from the United States to China for the ten months ending with October, 1905, were more than twice as large as for the same period in any preceding year; and this in spite of the boycott in China against American goods. In 1904, for the corresponding ten months, the exports to China from the United States were a little over twenty millions of dollars, up to that time the record amount, while, for the same period in 1905, the exports were nearly thirty millions of dollars more than for 1904 . In 1895 the exports of America to China for the ten-month period were $\$ 2,834,803$; for 1905 , ten years later, $\$ 50,104,767$.

The Pacific coast alone already produces very much that the Orientals need; that which that coast does not provide easily finds its way across the continent from the east along the 


\section{THE SELLING OF THE SURPLUS}

great railway routes; while, when the canal is cut, the Mississippi River and the Gulf will furnish their supplies, and the Atlantic seaboard will send its ships swiftly down through the route that, but for our blindness to our our facilities, as in the case of the Mississippi River, would long ere this have been opened between the two oceans.

While the trade with the Orient is yet in its infancy, it is remarkably varied in character, both outgoing and incoming, as may be seen from the following partial list of articles which we buy from and sell to the Asiatics. You may see very many of these wares swinging over the holds of every Pacific liner as you watch the loading or the unloading of an oriental cargo.

Incoming goods embrace: Coffee, silks, cocoa, goat-skins, raw silk, spices, tea, opium,sometimes one hundred and fifty thousand pounds in a year; tens of thousands of dozens of eggs, dates, starch, sugar, vinegar, woolthese suggest the variety.

Outgoing cargoes are made up of breadstuffs, flour, cotton goods, meat products, lumber, vegetables, tobacco, ginseng - the root 


\section{THE NEW EARTH}

so highly prized by the Chinese, and, to them, possessing magical qualities - agricultural implements, books, maps, engravings, candles, patent medicines, clocks and watches, dried fish, chinaware, dried fruits, glassware, printer's ink, gunpowder, iron and steel, locomotives, typewriters, musical instruments, leather, oils, writing-paper and envelopes, soap, candy, wines, hundreds of thousands of dollars' worth of cigarettes,- - the list is a long one.

In 1903, when we sold abroad nearly a billion, five hundred millions of dollars' 'worth of our surplus, not quite five per cent of this amount went to the Asiatics. At no time, from 1870 to 1900 , did the Asiatic export trade of the United States reach four per cent of our total exports. It is estimated that there are eight hundred millions of inhabitants in the Orient, with a trade, as indicated, approaching two billions of dollars a year. Indeed, the difference between less than nine per cent of this vast sum and the amount to which the United States is entitled by contiguity, by facilities, and by natural resources, forms a prize worthy the contest that is on.

But it is along the Atlantic seaboard that 
one comes closest in touch with the foreign trade of the United States. Eighty-seven per cent of our exports of the products of the earth goes to Europe. I passed along this seaboard studying the export trade situation, particularly in one of the greatest of the earth's products, flour. I started in at Newport News and made my way north through Baltimore, Philadelphia, and then New York, greatest of all American ports. Two facts of large significance stand out as you study the movements of the foreign trade from these and other American ports:

First.-Before you, across this mighty free highway of the Atlantic, lies what will remain for years, - it may be, if we do but arouse ourselves, for centuries,- the chief market of America, though it is not possible for any one to estimate the development of our Asiatic trade. The millions of Europe must be fed; they must be clothed; the supplies for both should increasingly come from the United States. Behind you, as you face the Atlantic, lies a country which, with all its progress in agricultural production, is but at the fringe of its possibilities. But it will always be able to 


\section{THE NEW EARTH}

keep pace with the increase in demand across this great waterway. 'There are those who maintain, and with no small show of reason, that if our present trade with our best customer, England, were suddenly to be cut off, so that for a year she should have absolutely no meat, no breadstuffs, no cotton, no supplies of any kind from the United States, the saddest famine in history would follow ; while continental Europe would pay off many an old score against, even if she did not wholly subdue, one of the greatest nations of ancient or modern times.

The second fact of large significance is not so comforting to our pride, or so suggestive of strength. Whenever you study the shippingbe it along the Atlantic seaboard or the Pacific, or the Gulf, or in Canada-at Victoria on the Pacific, Port Arthur on $\mathrm{I}_{\mathbf{3}}$ ake Superior, the great export wheat depot, Montreal, or Quebec or Halifax-you are conscious that the men who man the ships and unload the cargoes and appear at the docks as the representatives of the owners, or the owners of the ships themselves, if they happen to be in port,-you are conscious that these men are 


\section{THE SELLING OF THE SURPLUS}

not of your blood. And the flags, - ah, the flags! Save for the courtesy of the port which brings out your own colors,- - a hollow mockery from the standpoint of the commerce of the sea,-they are such flags as you seldom see unless you have traveled far in foreign landsthe St. George's cross on its field of red, symbol of the sea power of Great Britain; the three-barred flag of Germany, black, white and red, the tricolor of France, the merchant tricolor of Russia, with its bars the opposite of those of France, the colors of Norway and Sweden now forever separate,-your eye may even catch the white elephant of Siam upon its red ground, or the white and blue bars of Greece, while it will not infrequently and, on the Pacific, very often, see the striking emblem that symbolizes the rapidly growing strength of the commerce of Japan, the mystic ball of red upon its field of white.

And yet there is no small comfort to be derived from the fact that though the tonnage of American shipping has not quite doubled in a half century, while that of Great Britain has more than quadrupled, yet, taking the figures for 1904, the United States leads all 


\section{THE NEW EARTH}

nations in the world save Great Britain in the tonnage of her merchant ships, being nearly twice as much as that of Germany, her nearest competitor. It is interesting to note, however, that in 1850 the tonnage of British merchant ships was $4,232,962$, and that of the United States, 3,485,266, while in 1904 the British tonnage was $16,969,014$, and that of the United States 6,291,535.

A crowd of art students sat chaffing each other while the model rested in one of the famous schools of Paris. Many nationalities were represented, among them the Americans, - easiest of all, perhaps, to pick out. 'The conversation finally centered on the war between the United States and Spain, just then brewing. The European students voiced the people of Europe when they laid out before the Americans with commiseration the course that the war would take,- the ravaging of the seacoast of the United States, the destruction of American cities, the final success of the United States after immense losses by sheer force of brute strength, large numbers, and great wealth. But, echoing Europe, the Americans must expect it; they were a commercial nation, 


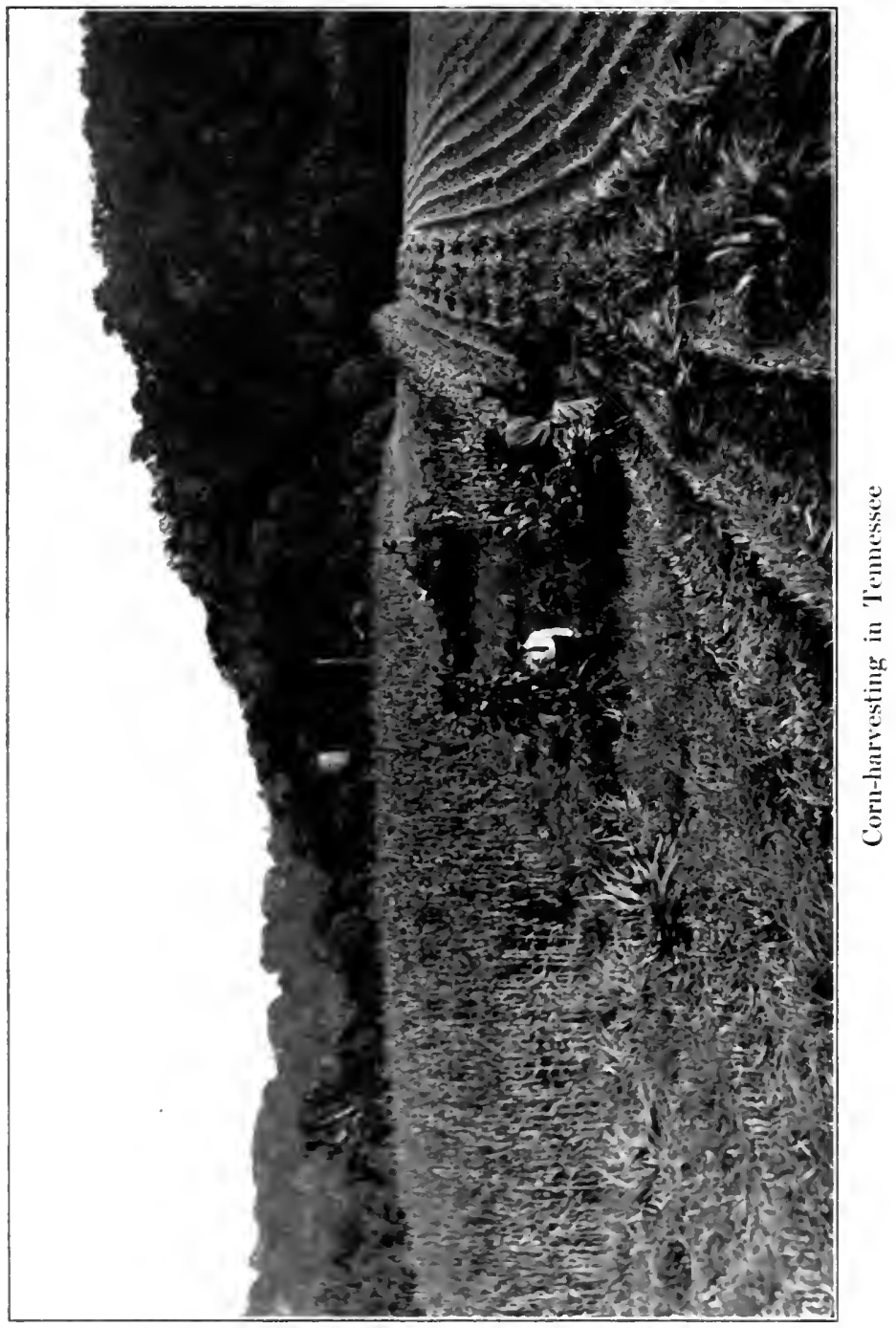





\section{THE SELLING OF THE SURPLUS}

not a fighting nation;- - they should never go to war with an old-world power.

The American students said, "Wait a bit; let us see."

'The foreigners jeered now,_- "Stick to your pork and wheat, your corn and your fruitsfighting is not in your line."

When the news of Manila came it was pronounced a miracle by the Europeans,nothing short of a miracle could account for such a victory on the part of the Americans.

When the news of Santiago came, and the art students sat around the model-stand during the wait, and the Americans asked the others if they had read the papers, there was no chaffing going on, no talk about the commercial nation that did not know how to shoot, but only such tokens of respect as all Europe was offering. And the greatest mystery to them, from some points of view, was this, that when the Americans had whipped the Spanish after one of the most exciting chases in all sea history, they were cager, to a man, to go to the rescue of the men upon the sinking ships at the risk of their own lives,it was a thing beyond comprehension! 


\section{THE NEW EARTH}

The European art students, like all Europe, were right; it was a peace-loving nation that was going to war,- - commercial nation, such as it is today, with, as yet, largely undeveloped native resources, able from its great granary to provide more and still more supplies for those who are dependent. The only difficulty with the foreigners was that they did not go quite far enough, that they did not take into account the fact that a man might handle a gun quite as well as a hoe, should occasion demand. 'The future of the foreign trade of the United States in the products of the earth seems practically limitless in its possibilities; it is in the pursuits of peace, not in the game of war, that the destiny of this country is to be developed. To those who gain their living from the soil, in whatever department of endeavor they may be interested, the foreign trade in the products of the earth is a subject worthy of their most painstaking and exhaustive study. 


\section{CHAP'TER XVII}

THE EXPERIMENT STATIONS

THREE agents in the dissemination of 1 the knowledge of the New Earth stand out above others:- the national government through its Department of Agriculture, the agricultural colleges of the different states, and the State Experiment Stations. In considering the scope and bearing of these three powerful aids to modern agriculture, it is not necessary to attempt to place one above the other,- there is quite enough glory to go round. Each in its particular department of endeavor has some particular influence larger and broader than that of either of the others. It is of peculiar interest to note, in this connection, that these three agents are essentially of the age of the New Earth. Many lines leading to the development of the new order of things had their rise in practically the same period, the beginning of the last third of the nineteenth century, - modern forestry, the 


\section{THE NEW EARTH}

great work of Luther Burbank, the knowledge of the structure of the earth, the inoculation of soils, the breeding of new wheats and corns, the control of insect pests, agricultural education, the national Department of Agriculture, the State Experiment Stations. It is singularly interesting to note the comprehensiveness of this renaissance, though it is rather a creation than a new birth.

In considering the great work of the Experiment Stations, it should be borne in mind that they are the property of the people, in a peculiarly close and intimate sense. While they are under the immediate control of scientific men, and articulate in a certain sense with the national government, they are preeminently popular in character. While no element of paternalism enters into their administration, they yet come into close relations with those who gain their living from the soil in directing and aiding them in their work. 'The keynote, if I may so use the figure, of the Experiment Stations, is absolute unselfishness. They carry on experiments and achieve results that would bring not only fame, but a large measure of profit to those who have the 


\section{THE EXPERIMEN'T STATIONS}

work in charge if they should seek their own ends. If the men who carry on this work of the stations should devote themselves to the mere acquiring of wealth, they would make more money in a year than they can make in a lifetime on the slender salary given them; for out of their discoveries grow, sometimes, rast sums of money saved to the state indirectly, large amounts brought to the people directly. So, unselfishness is the keynote. Like all unselfish work, it is successful in the highest sense.

These stations are, in the broadest sense, educational. 'They lead, stimulate, restrain, advise, control. 'They are pedagogic, without being paternal; influential, without being coercive; commanding, but never dictatorial. They have become, in some ways, the most powerful agent in their influence upon the functions and the developing of the New Earth.

There are sixty stations,--one in each state and territory, and in several states two, one in Alaska, one in Hawaii. 'They are organized under what is known as the Hatch Bill, a measure which became a law in 1887 . Work 


\section{THE NEW EARTH}

had been carried on for several years previous to this in similar lines, in some of the states. The national recognition carried with it an appropriation of fifteen thousand dollars a year for each station for maintenance. "This amount some of the various states quickly began supplementing, as the importance of the stations in their bearing upon agriculture became apparent. Lands and buildings were, in many instances, allotted by the states for furtherance of the work. 'The annual amount appropriated by the national and state governments is one million, five hundred thousand dollars, equivalent to only about fifty cents per inhabitant per year. The return on the investment, to put it merely upon utilitarian grounds, is quite beyond all ordinary percentages, so enormously are the stations adding to the wealth of the states. In a single decade, the North Dakota station, for example, is adding a hundred millions of dollars to the wealth of that state alone, ten millions of dollars per year, largely by reason of the experimental work of the station in the development of cereals. And this is but an illustration.

Usually the stations are affiliated with the 
state universities or agricultural colleges, and very largely the station staffs are made up from the college faculties. I do not know that I can, in any way, present a clearer view of the scope of the stations, than by giving the outline of their prospective work under the act establishing them, though the needs of the various states along particular lines frequently call for independent investigations in directions not included in the initial provisions of the government. 'The duties of the stations are prescribed as follows :

"To conduct original research or verify experiments on the physiology of plants and animals; the diseases to which they are severally subject, with the remedies for the same; the chemical composition of useful plants at their different stages of growth; the comparative advantages of rotative cropping as pursued under a varying series of crops; the capacity of new plants for acclimatization; the analysis of soils and water; the chemical composition of manures, natural or artificial, with experiments designed to test their comparative effects on crops of different kinds; the adaptation and value of grasses and forage plants; the 
composition and digestibility of the different kinds of foods for domestic animals; the scientific and economic questions involved in the production of butter and cheese; and such other researches or experiments bearing directly on the agricultural industry of the United States as may, in each case, be desirable, having due regard to the varying conditions and needs of the respective states and territories."

Along with this general provision it was laid down that the stations should issue full and detailed bulletins of their work, in addition to their annual reports, a bulletin at least once in three months, one copy to be sent to each newspaper in the state and copies to all those actually engaged in farming who should make request. 'These bulletins contain a mass of valuable information, practical in its character and intended to aid the farmer, dairyman, horticulturist, gardener-all who gain their living from the earth-in solving the many problems which come up in the progress of their work. 'The object is so to present the new discoveries that the average man may get hold of the facts easily. In some cases two sets of bulletins are issued,--one brief and in 



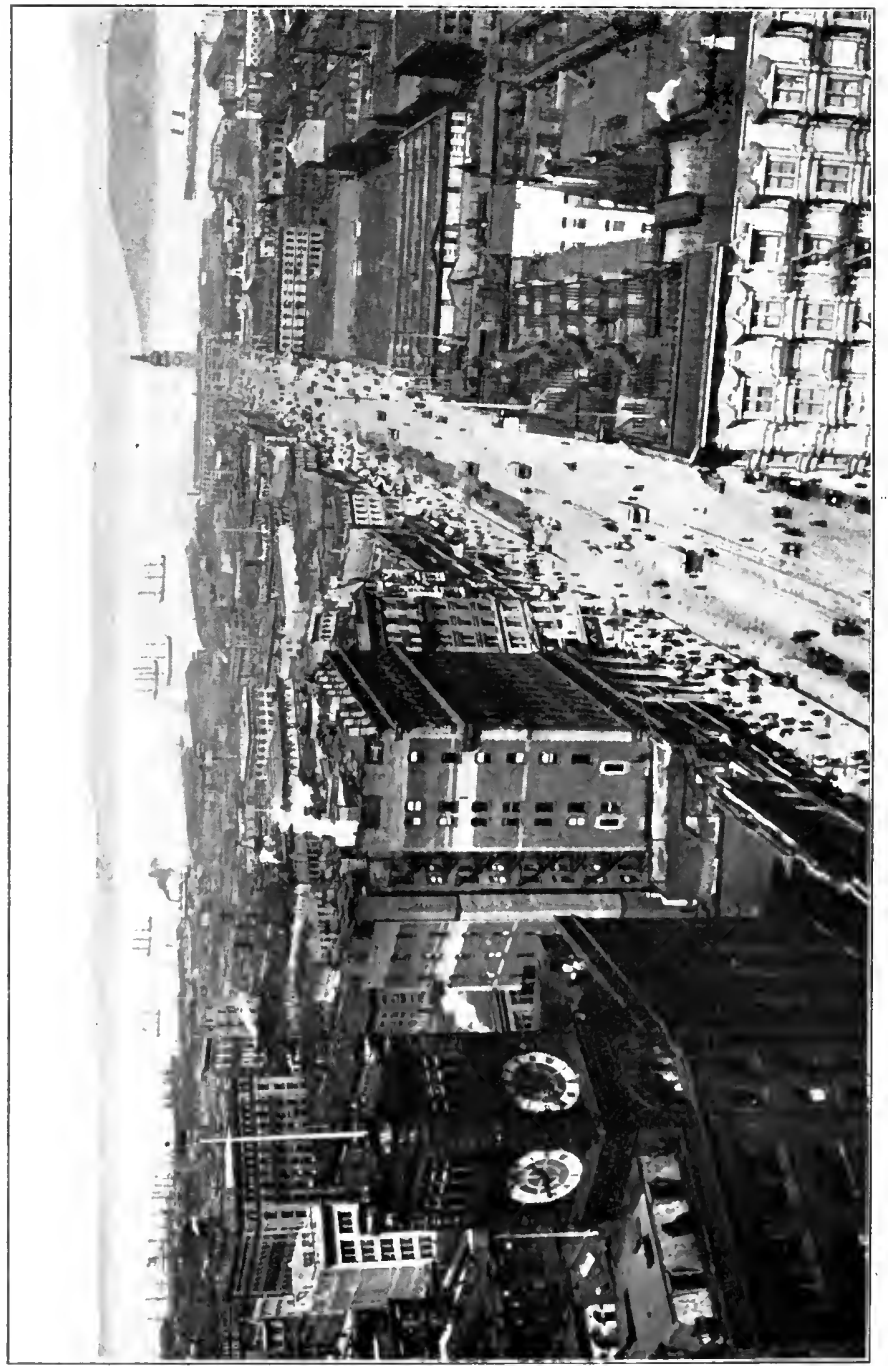

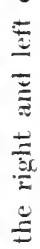

웅

르

造

$\cong$

$=$

홍

$\stackrel{\Xi}{\Xi}$

$\approx \Xi$

$\underset{\pi}{*}$

空

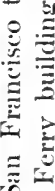

.

$\Xi \Xi$

萢

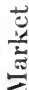

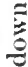

象 
the simplest possible language, for distribution to the press and for immediate use by the agriculturist, one more elaborate and scientific in its treatment. More than six hundred thousand farmers are on the mailing lists of these stations. Nearly a thousand men are on the staffs of the stations, among them some of the foremost practical scientists of the United States, and all of them picked men. They conduct original research in the lines of physics, chemistry, botany, geology, meteorology, agronomy, horticulture, forestry, physiology of man and animals, veterinary science, animal industry, dairying, rural engineering, and other related lines. In addition to these, they take up many questions of immediate interest and give the farmer first-hand aid; as, for example, they hasten to present the very latest information as to the eradication of an insect pest threatening crops or orchards; they give free expert opinion on the character of a soil or the healthfulness of a water-supply; they test a certain food which has fallen under suspicion and determine whether or not it is fit to eat, giving the inquirer precisely what the compound is made of ; they answer letters 
upon a thousand and one topics which may not have any direct scientific value or interest whatever. Hundreds of thousands of letters are mailed annually from the stations, embodying information which the farmer could not elsewhere get, and all of it free of all expense to him. 'The national government frequently unites with the stations in coöperative experiments. One station may have peculiar facilities for carrying out some experiments in forestry, and the national government brings to bear all its powerful influence to help forward the test; or, it may be, the best method of exterminating an insect pest, or a problem in irrigation, or a demonstration of the value of foods for man or beast. Often the men who are in charge of special lines of investigation in the stations prepare bulletins which are issued by the national government.

There is also an association of American Agricultural Colleges and Experiment Stations which meets in annual session, where papers are read and discussions held on many points of interest to all who are engaged in the activities of the New Earth.

Volumes might be written concerning the 326 
work which has already been accomplished at these stations. It would be impossible to give anything like an accurate estimate of the value, of these stations to the nation. The aid which they offer is vast in two directions,- the positive value, which is both direct and indirect and large in both, and the negative value, which is sometimes quite as important as the positive. The negative importance may be indicated by the words, What not to do. The period of the New Earth has been so short, time enough has not yet elapsed for a universal spread of the knowledge which has been accumulating, and much left over from the older order remains to be sifted, tested, accepted or rejected. It is fully as important sometimes to indicate what the farmer should not do as to show what he should do. His calling in this respect is not unlike that of every other man. For example, the stations have done great service by showing to farmers, on analysis of their soils, that they must not go on planting certain things because of the soil exhaustion sure to follow such continuous cropping. Again, they will be shown that certain fertilizers which they have long been 


\section{THE NEW EARTH}

applying to their lands are utterly valueless, or else that the amount of fertility they add is in no way commensurate witl ${ }_{i}$ their cost. Indeed, the station may show the farmer how he can make at home, at slight expense, perhaps not a twentieth of the cost he has previously incurred, a fertilizer which will do far better service. Very much knowledge has also been spread among the farmers as to food values, showing them by practical demonstration how great has been the waste of former years and how to check it. There is probably not a station among the whole threescore which has not proven in some particular line of investigation as great an aid negatively as positively.

One is confronted with a formidable obstacle in attempting, in any such compass as this, to show the direct and indirect value of the stations in a positive sense, an obstacle too large indeed thus to be overcome. One station does work in the reclamation of soils, like California, for example, which transforms whole regions of desert lands into rich orchards, simply by showing how these lands may be restored to fertility by methods devised by 


\section{THE EXPERIMEN'T STA'TIONS}

the station. Millions of dollars in value have been added to the wealth of this state by reason of the work of its Experiment Station. The details of how it was accomplished may be had by others simply for the asking. Another station gives out, free of all cost, the result of the investigations of one of its staff, and the whole dairy industry of the world is changed. In the invention of the Babcock test for butter-fat, Dr. S. M. Babcock, for whom the test is named, of the Wisconsin station, provided a simple, economical and absolute test for the ascertaining of the amount of butter-fat in milk, considered elsewhere more in detail. 'The result has been that many millions of dollars have been added to the wealth of the people, while the test has been adopted over the entire civilized world. 'The stations of various states in wheat-growing regions have added many other millions to the wealth of the states by reason of the creation of new wheats superior to old ones from every point of view, while corn has been bred for any definite purpose and largely increased in yield. Large sums have been saved in other states through the introduction by the stations of 


\section{THE NEW EARTH}

methods for preventing diseases among live stock; others have saved like sums by reason of their fertilizer experiments. Others have shown how to raise better fruits, how to protect crops from diseases, how to feed beet- and cane-sugar waste to cattle and provide good meat, as well as stop unnecessary leakage of profits, how to conduct farming on arid soils by means of improved irrigation methods, how to raise better stock, better poultry, more eggs, better beef, how to live better upon the farm on the rations at hand so that the farm dietary shall be not only attractive to the taste but strengthening to the body. You can scarcely mention an activity of modern agricultural life which does not depend upon the stations, directly or indirectly, for much of the effectiveness of its service.

There is one test which may be applied to all this great work which sets it apart from ordinary scientific investigation. It may be indicated in the question: Will it help?

The chief aim of the scientific agriculturist is not to do astonishing things, but to do helpful, practical things, those which aid the world to move with less friction, which make life 
for man and woman easier, which add to the sum of human happiness. It is never a speculative work carried on to satisfy the mere cravings of scientific curiosity. It is not the work of a day, either, but of long, patient investigation and study. Years must elapse in many of the tests before the end comes. Frequently, the end has no tangible results in apparent money value, but the test under progress may have been of extraordinary value through that which it demonstrated could not, or should not, be done. First, there must be demonstration, no matter how long the period required, and every step of the demonstration must be firmly established on facts, nothing can be left to conjecture; after demonstration, comes application, and it is here that those who gain their livelihood from the earth reap their benefits.

While there are, as noted, over six hundred thousand names upon the mailing lists of the stations, there are very many other thousands of names which should be upon these lists. The only requisite for securing the information needed is to ask for it. Any one who is directly interested in any department needs 
only to make request of the director of the station in his state, and the bulletins will be forwarded to him free of all charge. Frequently, too, bulletins can be obtained from other states by asking for them, and thus information may be secured from more than one source upon allied subjects. Direct communication by personal correspondence is also a source of much valuable information and aid. The directors are too busy in their great work to answer questions which have already been answered in their bulletins or which have no practical bearing, but they are ready at all times to give personal aid upon any topic needing further illumination. The work of experimentation is allotted to the specialists in the various lines, and these specialists are ready with their information on call. 'Thousands, indeed, tens of thousands of dollars may be saved to farmers in a few weeks' time in a given region by the station, simply by means of the information which is needed at once. Some difficulty arises in the region, something threatens,--it may be the raid of an insect pest, as the grasshopper, or a sudden and malignant disease among hogs or cattle, or, it may be, an 


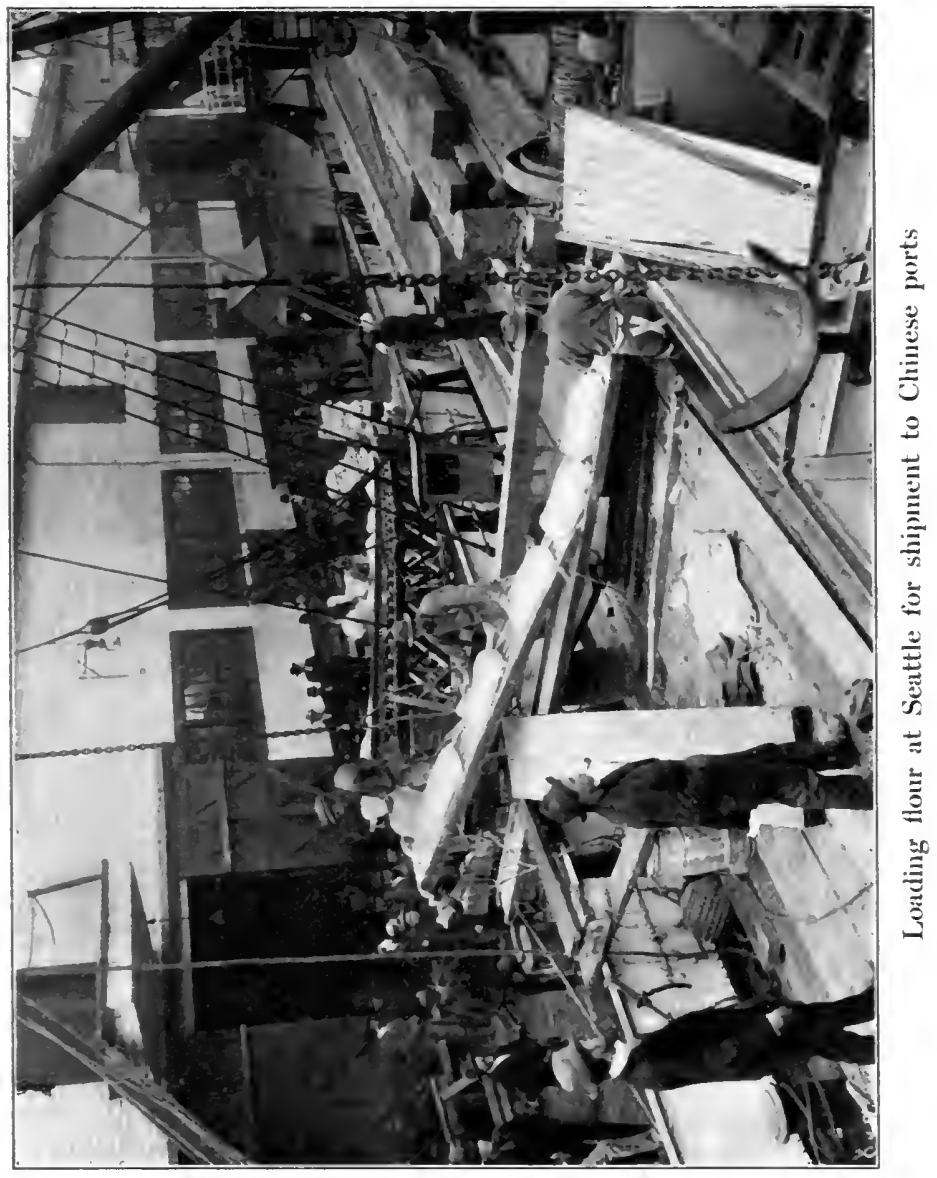





\section{THE EXPERIMEN'T STATIONS}

attack upon the cereals or the vegetables or the fruits. In case there is urgency, the specialist in charge of the department under which the threatened disaster logically falls takes the first train to the infected region. It may be that he can at once suggest the remedy, or it may be that he must make a closer study, if some new situation has developed, in order to grasp the situation; in which case he will suggest every possible means for immediate relief while investigating, to prevent a recurrence of the disaster another year.

In this way the aid of the bulletins, of the personal letters, or even of the personal visits which the farmers make to the stations, when they live near by, is supplemented in a decidedly practical way. Now and then special excursions of farmers, fruit-growers, and the like, are made to the stations, when the practical workings of the institutions are explained by the experts in charge.

Important as has been the aid of the state experiment stations to the American farmer, including under that term all who seek their living from the soil, it is far less than the aid still to come through the yet greater work 
now under way at these stations. Year by year new tests are coming into fruitage, new methods of doing things are ripening into action, new ways of making farm life more attractive and farm revenues more stable are opening. These stations, it seems not extravagance to say, are among the most conspicuous evidences that there is something else in American civilization besides greed and graft. 'They are founded on absolute unselfishness. They make their way forward, carrying aid and enrichment, and at the same time ennoblement, under the guidance of men whose highest aim is to help others to help themselves.

In an even more intimate way, the agricultural schools and colleges come into touch with those who stand debtors to the Experiment Stations. 


\section{CHAP'TER XVIII}

\section{AGRICULTURAL EDUCATION}

T $N$ some ways, the most important of all the 1 influences set in motion since the beginning of the period of the New Earth is the revival in interest in farming; or, better put, the creation of interest. Very largely this has been due to agricultural education, now at floodtide. In all the centuries, the work of the farmer had been, from many points of view, menial. Those who could own and operate great estates, with some one else to do the work, and with all the absence of disagreeable friction which wealth implies, were happy in their choice; - the vast mass of the farmers, however, were bound down to a distasteful life. Those adventurous spirits who did the pioneer work of opening the great West frequently were so deeply in love with the wild free life of the frontier that they entered with zest upon the hardships and privation of farm life; but a very large number of the men 
and women who have been the farmers of the republic have not entered upon, nor remained in, the life from choice.

With the introduction of agricultural education, along with the other important helpful developments of the life of the New Earth, came an altogether different point of view. The young men who went away from home to study in the agricultural schools returned with a wholly different idea of the farm life. They found that there were different ways of doing the same thing. They found that business methods were as pertinent to farming as to banking. They learned that it was not necessary to live a slovenly life on the farm, either in the field work, in the barns, or in the home itself; that a farm could be so administered that it would be a place to go to with delight, not one to be shunned and to be abandoned the moment something different offered; that there was money to be made in wise farming; and that, best of all from some points of view, it was wholly unnecessary for a farmer to forever live in the shadow of a mountain of debt.

With the revival in interest in the affairs of 
agriculture, it soon became apparent that an educated farmer was as essential to the best development of the farm, as an educated lawyer or jurist was needful for the proper administration of the law. Here and there had been more or less successful attempts to educate in agricultural lines, but it was not until the coming of the real practical agricultural colleges, mainly coincident with the founding of the great state universities, that agricultural education in America may be said to have been established. 'The first agricultural college in America, that of the state of Michigan, is not yet quite fifty years old; while the history of the larger number of them begins approximately with the beginning of the last generation of the recent century, the period of the New Earth. In 1862, in the midst of the Civil War, the Morrill bill, as it was called, was enacted by Congress to provide means for colleges for agricultural education. It granted to each state thirty thousand acres of land for each senator and representative to which the states were respectively entitled for the maintenance of these land grant colleges, a splendid service to the nation. But it was not until 
the war was over that the wisdom of the act became apparent. Then came the actual beginning of agricultural education in America.

About one-half of the agricultural colleges are independent of other education in the state, while the rest articulate with the state universities. Some of the agricultural colleges, or schools of agriculture as they are called, lead up to a longer agricultural course in the university proper, ending in a formal degree, though the schools are broad and comprehensive enough to afford a complete practical agricultural education.

I think the most serious mistake made in the earlier administration of some of these colleges was the effort to teach more than was necessary. The aim was not too high, but it was too broad. In a day like this, when such tremendous forces are at work in educational life, it is manifestly impossible for a student to master all. Some one has shown that it would take at least seventy years of the closest study successfully to take all the courses in a single modern university of the broadest type. Perforce a man must specialize to a degree, though not to the degree that eliminates sym- 


\section{AGRICULTURAL EDUCATION}

metry. I have in mind a student who followed a carefully wrought-out course in an agricultural college of the broader type. He knew quite a little of Latin, something of German, had dabbled a good bit in history and logic, and, if I mistake not, had spent two or three semesters in the study of higher mathematics and the evidences of Christianity. Along with this he accumulated much helpful information regarding farm life and farm activities, but, when he had been graduated, he was educated neither for the farm nor the forum, nor the pulpit, nor the bank, nor the business house,he was unbalanced, and much of his effort had been a sad waste. The trouble was that the agricultural part of the educational scheme was too narrow, the other part too broad. As a result, I do not think fifty per cent of the students associated with him went back to the farms to earn their livings. He became a corporation lawyer.

I have in mind another agricultural college, or, as it is more strictly called, a school of agriculture, which illustrates the better way of teaching young men to be farmers, and which, by reason of this teaching, sends back ninety 
per cent of its students to take up gladly the life of the farm. For a young man who has had four years of training in such a school, who has been shown that in practical and scientific agriculture lies opportunity for progress, such as almost no other line of life affords, and who has found out, at the same time, that he can make money upon the farm, - for such a young man there is scant temptation to rush to the city, there to be swallowed up among the millions, to become a dependent, to face the cold facts of small salary and large expense. He goes out from the agricultural school independent, a king among men; he is untempted by the allurements of the streetcar, or a meagerly paid clerkship, or a narrow, specialized department of some grimy trade. 'The city calls to honorable service, to be sure, but it is trammeled; the country call is for a life of freedom and abounding health.

In such an agricultural college the practical is always uppermost. Follow a young man through a day's work, or a composite day, we will say, made up from different days in a term, see how wide is the reach of the knowledge: He knows how to make every implement in 



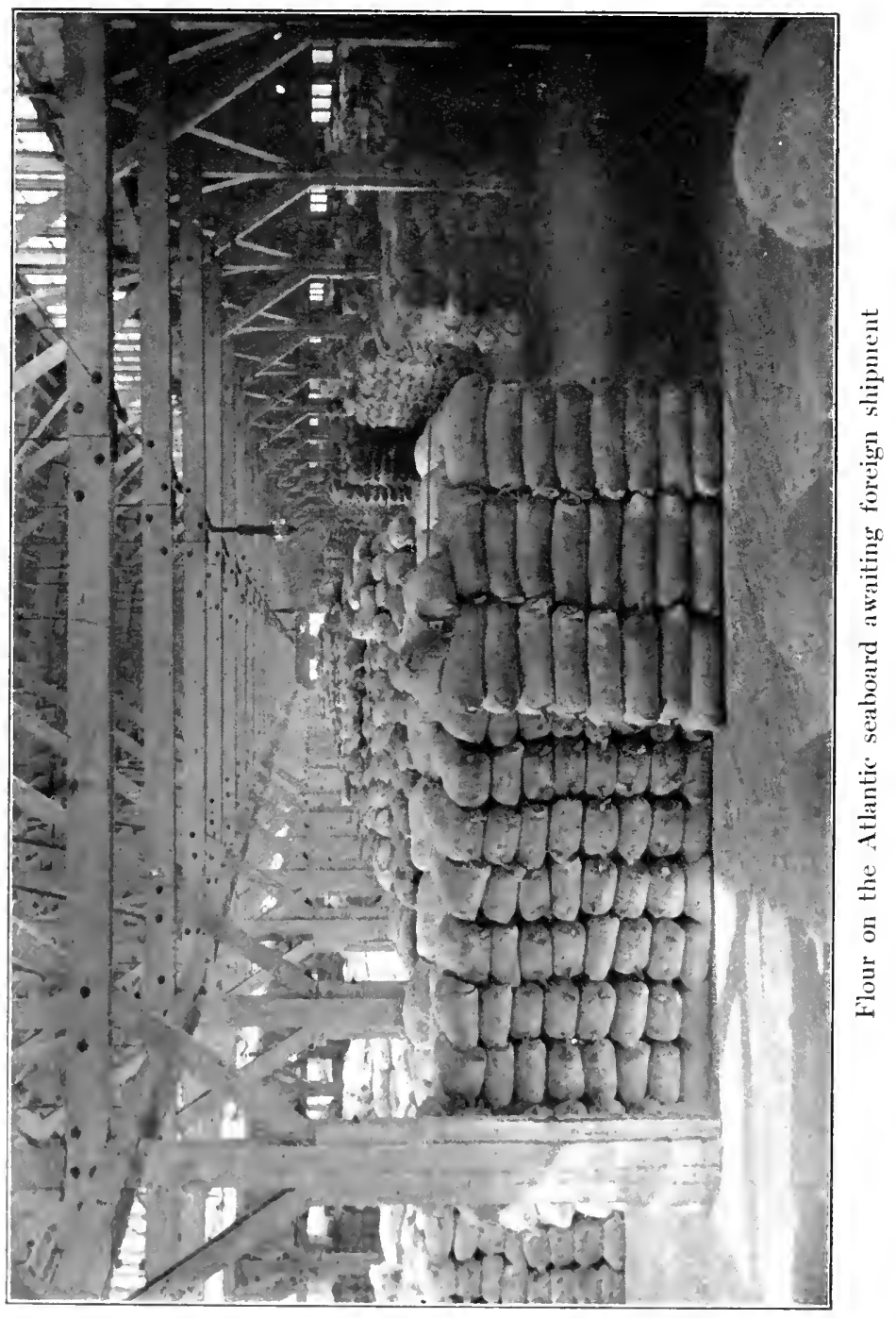


use upon the farm, be it wood, or iron, or steel, and how to make the tools that make the implements; how to repair, at his home-made forge, a machine, a mower, a harvester, a plow, or what not - while, under the old order of things, all the labor of the day would stop while some one went to town to have the break mended, there to find the village blacksmith beside himself at the array of broken machines awaiting their turn. 'Time, money and patience are thus saved in liberal portions. He is taught, also, how to take care of machinery, an important feature where one hundred millions of dollars' worth is bought each year by American farmers. Vast waste was suffered in the past through neglect of farm machinery,--the new man knows how to take care of it.

He learns how properly to kill and dress cattle, sheep and poultry. Many a farmer of the Old Earth did not know this, nor did he have any comprehension where lay the choice cuts of the beef. He ate the worst and sold the best, and cursed the tax on his teeth and jaws. The new farmer learns that it is quite as easy to have good meats on the farm as to have poor meats. 'The anatomy of every 
animal to be killed is accurately learned, and the relative values of every piece of meat. This, and how best to dispose of the refuse, how to cure the meat, how to prepare it for market, are also among the things taught. He learns how to select a dairy cow, and how to breed stock that shall do the best service for the dairy and the market; what breed is best adapted to his climate and locality; how he may provide, at the lowest expense, the food for the market cattle, in order that he may make the most money from his investment; and he gets acquainted with the horse, that noble friend and helper, in so intimate a fashion that he can not only take life easier himself through his use of the horse, but make life infinitely more bearable for the horse. $\mathrm{He}$ learns how to care for fruit trees; how to plant and prune and graft; what to select for his climate, and why; how to prepare fruits for the market or for his own winter food. 'The lifehistory of weeds, and how they rob the farmer, together with such an intimate knowledge, that out of a hundred weed seeds he can accurately name the weeds themselves merely by size, shape and color of the seeds; what 


\section{AGRICULTURAL EDUCATION}

sort of crops is suited to a given soil, and why; how soils are made; what makes the wheat kernel give strength to the body; what takes place while food is being digested; what foods are most useful, and why; what makes a balanced ration for man and beast; how to make the best butter and cheese, and how to rear and care for and make money out of poultry,-these but suggest what this new factor in farm life has for capital, when he leaves the agricultural school and eagerly turns his face toward the farm he would have returned to with an intense and bitter hatred in the not far distant days of his ancestors.

But the light of the New Earth, as it is illuminated by modern agricultural education, does not shine alone upon the man's side of the page. Along with the young man goes his sister. She must be in close touch with the new life of the farm. She must be as fully equipped for its broader service as her brother or her husband-to-be, or the whole enterprise falls to the ground for lack of balance. So the new agricultural education is for both young men and women. 'The girl not only learns very much that the boy does, going with him 
to many classes where, once upon a time, it would have seemed indelicate for her to appear, but where, in all womanly sweetness, she learns what she ought to know, but she has her own individual classes which he would hardly care to join because they deal with matters which belong primarily to the home. And greatest of all the influences which are flowing out of this dual education, is that which makes the home life upon the farm attractive. When the farm home is attractive, the corner grocery or the saloon will not be. When around the farm-house there are thrown all the refining influences of music and pictures and books and magazines; when the cuisine is as carefully planned and the dining-room as carefully superintended as the stable or the dairy ; when the food is sensibly prepared and served in an attractive manner, and, at the same time, at a marked saving in expense; when drudgery is transformed into dignified labor which may be hard, but which is never menial,-then the farm home is as full of attractiveness as the most exquisitely appointed palace in the heart of the town,- - ah, indeed, perhaps more so.

Go with this country girl through a com- 
posite day's work in the agricultural school: First of all, she learns about herself, the one person of whom, had she been reared under the shadow of the old life, she would have been most densely ignorant. There are wise teachers who know how ignorant she is, a motherly matron who knows what she ought to know, a physical director, a woman, also, who puts plainly before her the functions, the imperative needs, the possibilities and the responsibilities of her life. So at the very outset she is made mistress of her own personality,-physical, mental, and moral. Then how the knowledge of new things broadens before her! She studies the chemistry of foods; she learns how to prepare and cook foods so that there shall be a maximum of service and a minimum of waste; she learns the dairy by heart; she knows as much as the young man by her side of the secrets of the grains, the grasses, and the soils; she comes under the sane control of a woman, who teaches her how to make her own clothing and that of her children when once she shall be so blessed, how to do all manner of deft stitching and mending and laundering; how to turn her 
hand to the finer lines of needlework and embroidery, so that these may be hers if ever she cares to follow them; how to direct a household in its deepest and broadest activities. She is mistress, too, not only of herself but of her household. Her knowledge is preeminently practical,-hygienic, dietary, economic ; she is fitted for the degree of Mistress of Domestic Science, if such there were to confer. And along with all this has gone other knowledge, so that she shall be broadened as well as deepened. She, with her brother, may go on, too, if she wills, into the more extended university course; but whether or not she ever takes the larger course, she is most admirably fitted for the life she is to lead. She has been shown also the importance of progress. She is eager to know more and she will know more, too, for with the broader training which has made her systematic as well as symmetrical, she will have more time to give to her own cultivation when once she is back upon the farm surrounded by precisely the same implements of culture that her city cousin has, - pictures and music and books.

So the life of the farm has been trans- 


\section{AGRICULTURAL EDUCA'TION}

formed. Much has been done by the telephone and the railroad to relieve it of its terrible isolation, particularly the former. The dead level of humdrum cares and the awful monotony of the old way of life were sadly devoid of stimulation, they led to irritability and then to dissatisfaction and then to settled moroseness, sometimes to mania. It was a powerful figure, woman or man, who rose above the monotony and grind and the insufficient equipment and the distasteful life and maintained a cheerful outlook and a generous grasp of joyful things. Under this new order of things the farm life becomes one of the most attractive in the whole range of human activities. Refinement, culture, enough luxury, but not too much, an occupation that makes good health imperative, a steady increment in capital and a generous income, an intimate touch with the outside world by reason of the telephone, the trolley-car, the daily newspaper, the free rural delivery-it is, in many ways, an ideal life; it is small wonder that the tremendous movement toward the city is being here and there checked; the outflow has already begun. 
Some time before the issuance of this volume, the writer had occasion to secure data from the various agricultural colleges from which to draw certain conclusions for a paper published in the "North American Review." 'The various presidents gave, among other things, the percentage of graduates who went back to the farm on graduation. Wide differences appeared, the percentage falling as low as ten, in a good many cases not rising above fifty, and only in one or two instances reaching one hundred. 'These differences are now disappearing under the newer order, so that the day should not be far distant when practically all the young men and women educated in the wisely conducted agricultural schools and colleges will go back to the farms on graduation. Already nearly ten thousand have been graduated, and if seventy-five per cent of these have returned to the farms, each one exerting an ever-widening circle of favorable influence in his immediate vicinity, the aggregate influence must be very large. It is this aggregate influence that is responsible for very much of the remarkable agricultural progress of America. 'The number of graduates must now rapidly 


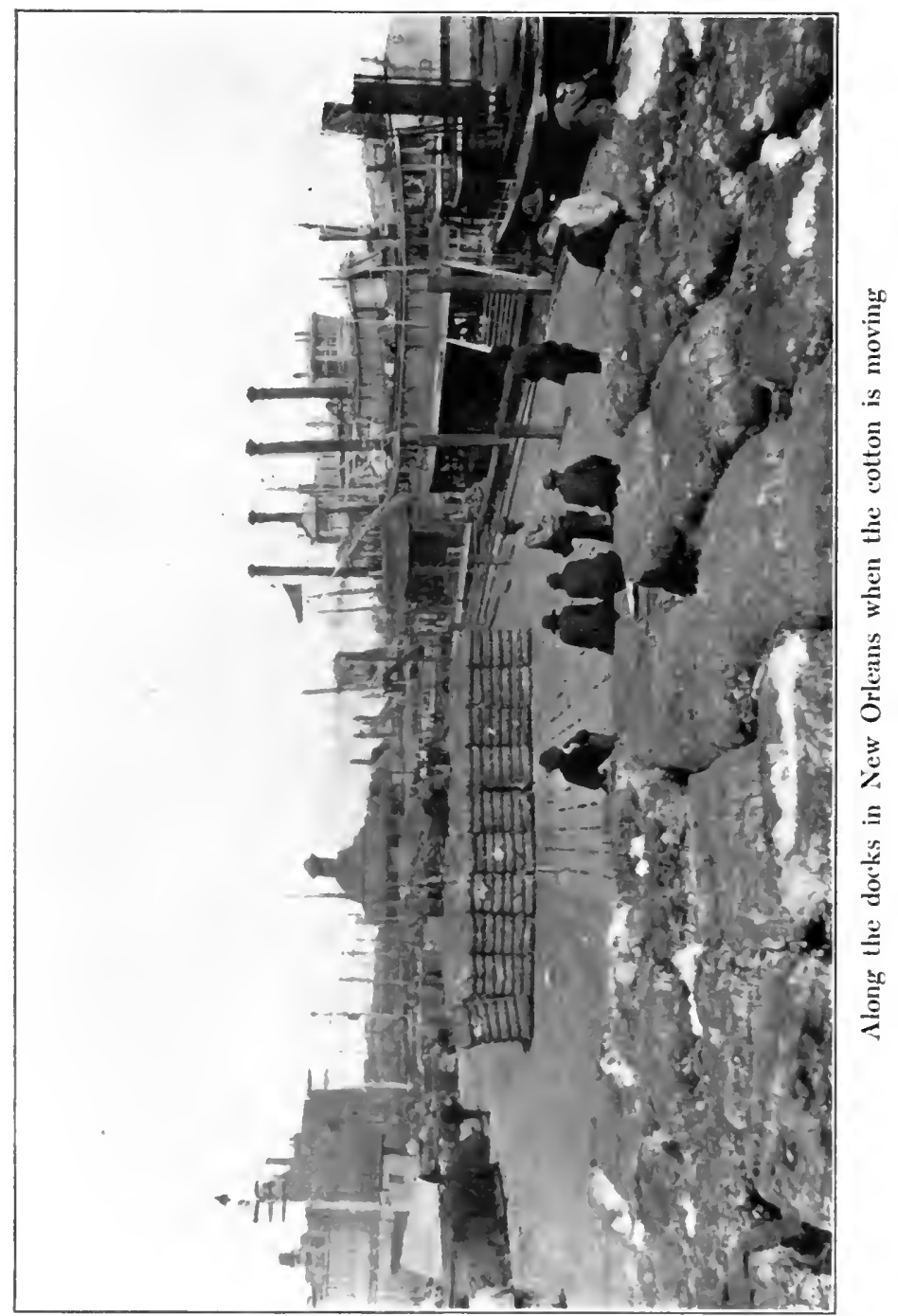



increase, the total attendance being about fifty-five thousand.

In addition to the work of the agricultural schools and colleges, important fundamental work is being done in many states in the country and even in the city schools, in the way of teaching the younger students the principles of elementary agriculture. In this instruction the student in the country school not only receives, by the novelty of the work, an added stimulation for his other studies, but he begins to learn the secrets of the life about him, is gradually brought closer and closer into touch with nature in his formative years, and it is many to one that such a course of instruction will bear fruit in permanent interest in and liking for the functions of the farm.

The most important feature of all this New Earth education is that it carries with acquirement of knowledge a strong and abiding interest in the learning itself and the things learned about. As this knowledge is now presented, it not only shows, in its more practical aspect, how material interest may be enhanced, but it makes a powerful appeal to the imagination, to the love for the beautiful, 


\section{THE NEW EARTH}

to all that finer and higher life which gives tone, and symmetry, and poise. Agricultural education in America has become a powerful factor in shaping national life. We shall find that the national government has not been bchindhand in this period of the New Earth in its efforts to help forward the interests of those who come in closest contact with the mother of us all. 


\section{CHAP'TER XIX}

WI'TH the rapid development of this country in post-colonial days, it became more than ever apparent that, whatever America might do in manufactures, it was preëminently an agricultural nation. From time to time efforts were made to give this fact national recognition, such recognition as had for many years been demanded, but all efforts were unavailing. In the midst of the Civil War, when the interests of the country, North and South, centered in that struggle, the national Congress turned away from carnage long enough to establish, on May 15, 1862, the Bureau of Agriculture. The enactment of the law providing for the bureau said:

"There is hereby established at the seat of the government of the United States a Department of Agriculture, the general designs and duties of which shall be to acquire and 
diffuse among the people of the United States useful information on subjects connected with agriculture in the most general and comprehensive sense of that word, and to procure, propagate and distribute among the people new and valuable seeds and plants."

The initial report of the new Department, issued under the direction of Isaac Newton, the first Commissioner of Agriculture, who held the position from 1862 to 1867 , brought out these, among many other points, well worth considering in these later days:

"Agricultural pursuits," he said, "tend to modify and tranquilize the false ambitions of nations, to heal sectional animosities, and afford a noble avenue of honorable rivalry. The acquisition of comparatively slow but sure wealth, drawn from and invested in the soil, develops health of body, independence and simplicity of life and love of country; while the rapid accumulation of wealth, not by production but by trade and speculation, is unnatural and unhealthy. It attracts men to cities and tempts men to wild investments. It too often unsettles moral principles and substitutes selfishness for patriotism. Men of 
the country, living in calm content and forming almost the entire wealth and population of the Union, constitute the truly conservative element in our politics. The men of the city, living in the midst of excitements-political, social, monetary and moral-too often feed these baneful causes of national ruin, to wit: Speculation, luxury, effeminacy, political corruption and personal ambition. . . . Agriculture is the cause and evidence of true living; for where tillage begins, barbarism ends and the various arts commence. When agriculture prospers, all other interests prosper. When this fails, depression, panic and ruin ensue.

The United States is, and must always remain, an agricultural nation."

While the developments of recent years show very clearly that the United States is something other than an agricultural nation, the manufacturing and strictly commercial interests having risen to colossal proportions, yet, in essence, the commissioner was right. America is as dependent as ever upon agriculture today, - as dependent as it must always remain. The establishment of the Department of Agriculture, though a tardy act, was yet in 
time to help upward and onward the tiller of the soil at a time of great crisis, when the swords were being beaten back into plowshares. Coming, too, at the very beginning of the period of the New Earth, it emphasized the revival in agricultural interest and gave promise of national recognition upon a generous scale.

'This promise has been splendidly fulfilled. The department itself has passed through many crises, has made its own lamentable mistakes, and sometimes may have been halting when it should have been aggressive, but it has been administered in sincerity and it has been a credit to American life; it has been of vast help to the people.

Little by little, as the new thought has spread, the Department has broadened its scope to keep abreast with the progress of the New Earth. One by one new departures and advances have been made, and one by one old features have been taken up where they showed signs of slumbering vitality and revivified. The initial object, to acquire and diffuse knowledge, has steadily been kept in mind. A review of all the lines of approach to the 
affairs of the New Earth which have been laid out by the department, would consume more space than may here be given, but we may briefly consider some of the more significant of them in an effort to indicate the powerful influence of the department upon the life of the tiller of the soil.

Conspicuous among these lines at present, by reason of the great popular interest which has of late been aroused in plant life, is the Bureau of Plant Industry, which aims to give national aid to the farmer, the horticulturist, the market-gardener, to all who are immediately interested in vegetable life. Large numbers of men are employed in this bureau engaged in searching for new plants in all quarters of the globe, and in determining whether or not these plants are practicable for introduction, and whether, if transplantable, they are desirable. The work has proven so important, it has broadened rapidly, so that it has become quite impossible to keep up the supply of men. These men must be particularly fitted for the work. Three qualities are at least essential, - a fondness for it, education for it, and adaptation to it. All these must be 
cemented together with shrewd common sense and no small degree of diplomacy. 'These men, called agricultural explorers, are now distributed practically over the entire globe. As rapidly as others can be trained the globe is divided into smaller regions, in order that more work may be done. Five hundred men are already, in 1906, under service in this bureau, and it is only a few years old. Sixty per cent of these men are engaged in scientific investigation and its application to the farm, orchard and garden.

While the scientific side of the work is conducted with earnestness, the practical side is by no means overlooked, but rather emphasized. For example, the bureau has undertaken the direction of farms in certain regions, particularly, at present, in the South, where problems which baffle the farmers of the locality are worked out before them, and the reasons for doing the problems in such and such ways are clearly demonstrated day by day. Thirtytwo of these farms are now under the supervision of the bureau, located in Louisana, Texas, Georgia, Alabama, Mississippi, South Carolina and Florida. Representatives of the 



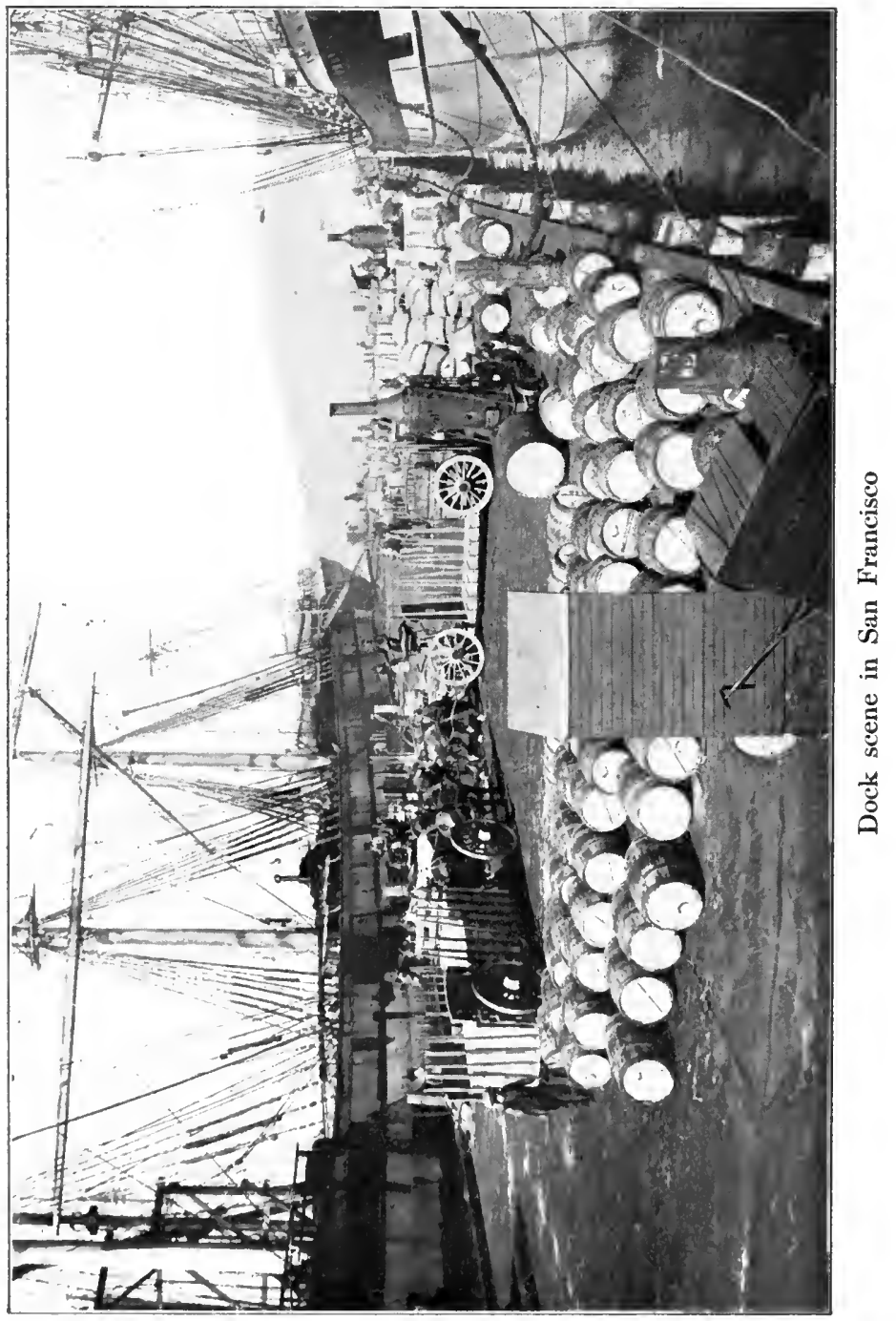


bureau, usually in connection with representatives of the experiment stations of the several states, plan out the work in a systematic manner. This includes not only the actual demonstration of how a crop should be cultivated in order to make the most money out of it, but also elaborate systems of records showing the steps taken in each individual case. At all points, the aim of the department is not to be paternal in the administration of these farms, but to be helpful; realizing also that it is the money of the people that is being spent to carry this work forward and that it is in no sense a private enterprise.

Another important branch of the plant bureau is the investigation into the relative values of plants and the improvement and adaptation of them to new conditions. The bureau also undertakes work in the developing of new fruits, the reclaiming of sand-dunes along the seacoasts by means of sand-binding grasses which thwart the winds and the tides, the restoration of over-grazed ranges, as in A rizona,- - where the land, once rich in grasses for the herds, rapidly becomes a desert,- the danger being averted merely by restricting the 


\section{THE NEW EARTH}

number of animals allowed to browse. It has done extensive work in the introduction of the macaroni wheat, which will thrive on soils where the common wheat will not, and much is expected from this new cereal.

The Department has had supervision of other important work in lines allied to this, notably in the cultivation of cotton. The cotton-raisers of the South have been aided, not only by the introduction of better methods, but by the production of new types of cotton. Rice, also, has been under the close study of the Department, because it was seen that the rice-raisers of the South were not getting back from their labor an equitable return. So better ways of cultivation have been suggested and a rice-farm, or -plantation, has been established in Louisiana by the Department for the solution, in a practical way, of the problems which arise in the cultivation of this important food. Much has been done, also, in the way of testing new varieties of rice. 'The production of rice in the South has been largely increased as a result.

'The improvement of the sugar-beet seed has been, for a long time, under way. Strains 
of what are called pedigreed seeds, tested seeds whose whole life-history is known and recorded, and which are known to be capable of producing increased yields, are now available. The coöperative work in tea-raising in South Carolina has resulted in the production of a superior grade of tea, quite beyond the ordinary commercial importation. The young tea-leaves alone are selected for the best of the crop, and the eight or ten thousand pounds now produced on the experimental farm in a season is many times more valuable than the imported grades. Demonstrations as to the value of alfalfa as a forage crop, and that it can be raised in almost every state in the Union; plans for the introduction of nitrogen-producing bacteria for the restoration of worn-out soils; the solution of problems in cold storage of fruits, as well as aid in the matter of better methods of fruit marketing,- these suggest other related lines in which the Department comes into close practical touch with the people.

The fact that nearly fifteen hundred new kinds of seeds and plants were introduced by - the Department during the year 1904, includ- 


\section{THE NEW EARTH}

ing three hundred and fifty date suckers, representing forty-two varieties, nineteen varieties of grapes from the Russian Caucasus, thirty-three varieties of mangoes from central India, one hundred and fifty-seven bushels of berseem from the Nile valley, two thousand pounds of the new Moravian barley, and two hundred hardy Russian cherry trees, indicates the progress being made in this direction.

While the Department is doing much in the way of the reclamation of arid soils, showing by experimental work in alkali lands the value of certain forms of drainage and other devices, the work coming under the head of the soil survey is of particular interest. Here the practical help of the Department to those whose living comes from the soil, and, indirectly, to all the people,-for all are, in a very positive sense; dependent upon the soil,--is shown. 'The Department has now surveyed and mapped out bodies of land in thirty-three states, aggregating, all told, nearly fifty millions of acres. Elaborate tests are made of the soils in all the different areas in order that the farmers, fruit-growers, grazers, or what not, in each individual locality, may know the exact 
character of the soil they are using. Along with this the farmers are shown, by practical demonstration, the importance of diversifying their farming. A portion of the money necessary to carry on this work is provided by the states, but the major portion comes from the general government.

The Bureau of Forestry, elsewhere referred to more at length, is now one of the virile divisions of the Department; the Weather Bureau, which has become of incalculable value through its warnings of cold waves, frosts, floods, storms of all types, and the like, now a branch of the Department, comes into particularly intimate relations with those who gain their livelihood from the earth, and more especially since the introduction of rural delivery of the forecasts by telephone; the Entomological Bureau has come prominently to the fore in its efforts to combat the cotton-boll weevil, an appropriation of two hundred and fifty thousand dollars on the part of the national Congress in aid of the work indicating the interest taken; the Bureau of Animal Industry not only keeps a check on the production of undesirable meats at home by reason 


\section{THE NEW EARTH}

of the meat inspection service, but fosters and encourages the foreign trade in meats; the Bureau of Chemistry is doing a most important work in the exposing of frauds in foods as well as in the establishment of food values and what constitutes the most sensible ration for man under all his different conditions of in- and outdoor life.

The great scope of the work of the Department may not be more than indicated here, but it will be seen that these bureaus constitute one of the most important aids to the advancement of the interests of the New Earth.

In coöperation with officials in various states, - and this illustrates the wide scope of the work of the Department,--object-lesson roads are being constructed, showing in a practical manner the solution of the good-roads problem,- - one of the most perplexing and costly problems, by the way, that come up for solution, particularly in the newer portions of the country. 'The Department considers the subject of country roads in America so important that a school for road-building is projected, the students to consist of men who have 
already received degrees from reputable engineering schools.

The Department of Agriculture comes into intimate touch with the activities of the New Earth through its articulation with the state experiment stations, through educational influences, through all these lines of practical work indicated by the bureaus, and through the close contact of many of its agents with the people as they travel over the country, but in a still deeper and broader manner it reaches the people through its publications. During a single year, 1904, the Department printed twelve million, five hundred thousand copies of its various publications. Six million, five hundred thousand farmers' bulletins alone were issued. During the year the Department brought out nine hundred and seventy-two distinct publications, three hundred and twentynine of them being new. They contained twenty-two thousand pages of reading matter, a library in itself for those who are learning, under the new order of things, how valuable is the printed word when it is sensibly set forth. There are over four thousand, five hundred people directly employed in the Department, 
and nearly two hundred and fifty thousand people are acting as special correspondents throughout the world without compensation,a loyal army of assistants, which attests the interest taken in the work.

Among all the great industries of America, its colossal manufacturing activities, its vast commercial interests, domestic and foreign, all the intricate network of professional, business, and labor interests,-among all classes of Americans, where else shall we look for such aid as this which the national government is bestowing free of all cost, upon the followers of but one occupation among the many? It is indeed a significant commentary on the importance of agriculture in America. It is a suggestion of the universal application of Liebig's principle, "Agriculture is the foundation of the riches of states." It is a commanding recognition of the dependence of the nation upon those who till the soil. And it is an equally commanding message to all who till the soil that theirs is an occupation set apart, bearing the august stamp of the nation itself. 


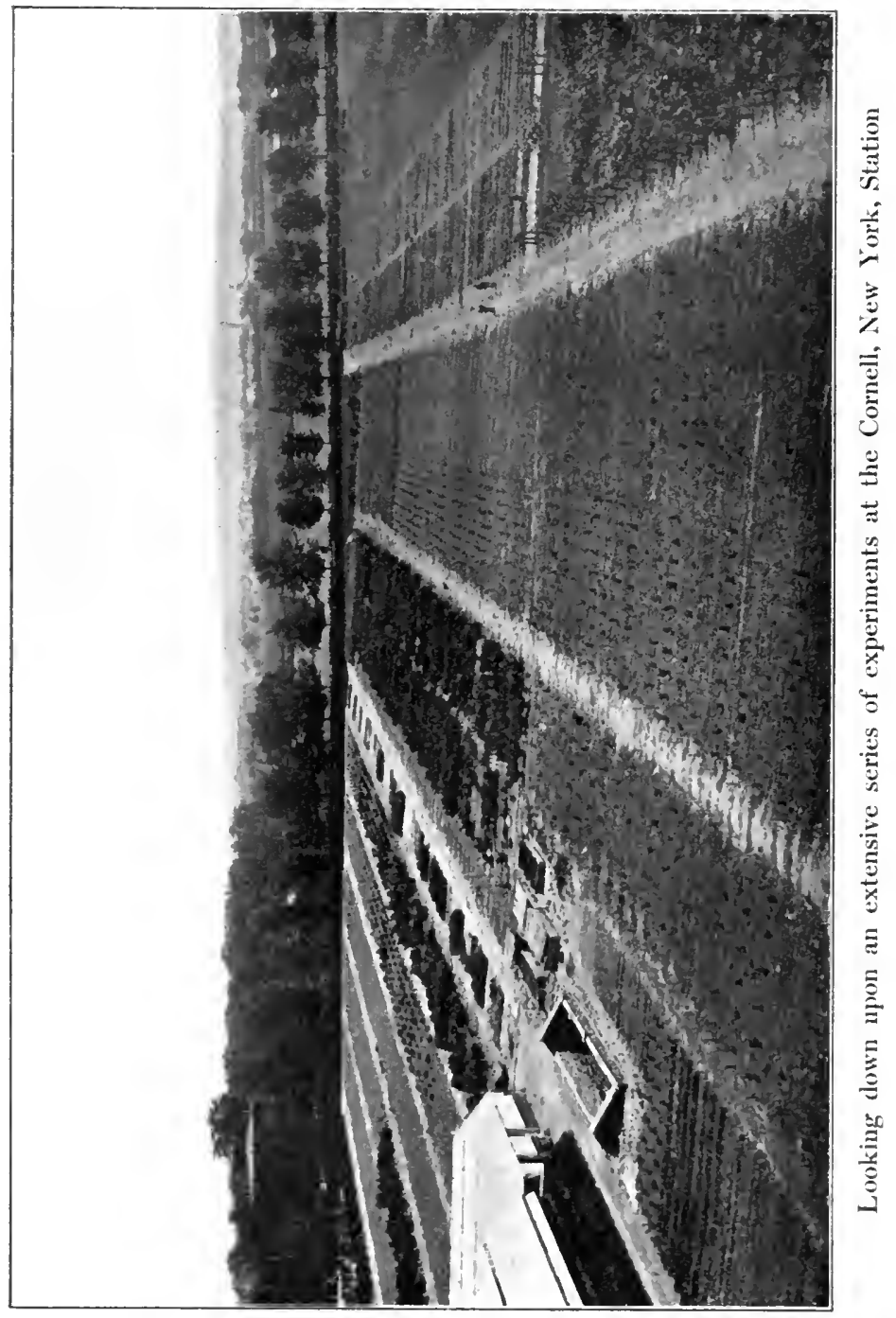





\section{CHAP'TER XX}

THE IMPORTANCE OF THE FARM

THE keynote of the farm life of to-day is

1 independence, and the harmony is major. 'The keynote of the former generation was dependence, and the music was minor to the end. For now the farmer, and by this may be included for present consideration all those who earn their living from the earth, is coming into his own. He has passed through many preparatory stages and the road has been thick with thorns. He has been trained in the harsh school of experience and has been graduated with full honors. $\mathrm{He}$ is master now, servant no longer.

I do not know that a better concrete illustration of this can be found than that afforded by a body of five hundred Iowa farmers whom I visited one day when the earth was falling into the mellow mood of autumn. 'They lived in a rich agricultural region, once the center of a great wheat-raising industry but now 
given up to diversified farming, a line of activity which has had a marked bearing upon the success of the farmer of to-day. Their soil, sensibly cared for, was so productive, and the demands for their corn, their cattle, their sheep, poultry, and all manner of food supplies in the rough, was so steady, they should have been of all men most independent. But for years they were sadly dependent, even after they passed the ten-dollar-an-acre period and their farms were rising in value to double or quadruple that figure. They were at the mercy of others who were not merciful. 'They had patiently endured the slow strangulation of greed.

It occurred to one of their number one day that they were like other men, after all,-like merchants, bank presidents, railroad managers, and so on, and quite as much entitled to freedom as the owners of the railroads that were unfair to them, or the dealers in agricultural implements who charged them too much, or the merchant of their little town who steadily bled them. So a number of them got together and talked the matter over. "Why not go into business ourselves?" they said. "Why not 
establish a plain business firm? A lot of farmers could make up a firm, surely, as well as a lot of towns-people ; not a coöperative concern, not communal, just plain business."

The idea was a novel one. It took root. It began to be nourished by the dismal rains even of further meanness. It grew strong and sturdy under the winds of opposition. A firm of five hundred farmers, - such a thing under the old order of things would have been as preposterous as a firm of five hundred doctors, or ministers, or university professors.

But the leaven was at work, and the firm was established. A manager was chosen from their own number "to look after things," and they began business. First, they said they had not had a fair deal from the merchant in their little town, the only merchant in the village, which was the focal municipal point for their farming region. He had charged them his own prices for his wares, and paid them his own prices for their wares. He was altogether too thrifty. The farmers said, "As a firm we will now buy our goods at wholesale and sell them back to ourselves at a slight advance to cover expenses. We will also," they said, "put up our 
own grain-elevator and build our own cattleyards, because we may want to store our grain and hold our cattle until we get what seems to us a fair price for them." 'The railroad companies said, "Very well; if you people do this we shall be obliged to put up a grain-elevator at another point several miles from your own and to draw all the trade away from you by paying more." And the farmers laughed and said, "Nothing would please us more, for we are after higher prices, and if you can pay us more than we can pay ourselves we are that much ahead: the law, by the way, compels you to carry our goods whenever we want them carried." The railroad companies saw the point. Then the implement dealers said: "You men must buy your machinery from our regularly appointed agents at retail; we will not sell to you as farmers." And again the farmers said, "We are a business firm, now; we will buy of you if we can; force you to sell to us by law if you refuse, if we can; failing in this, we will manufacture our own machinery." The implement dealers saw the point also. The wholesale dealers in all sorts of materials the farmers must have-coal, salt, fence wire, 


\section{THE IMPORTANCE OF THE FARM}

flour, provisions, dry goods, clothing-saw that the farmers were now the only firm in the region, for they had put the greedy merchant to flight by refusing to be bled by him longer, and the wholesalers wanted this trade. Everybody saw the point.

Now these five hundred farmers had five hundred farms. 'They were worth, on an average,so well developed were their farms and so stable were farm values, - at least ten thousand dollars each. Most of them were out of debt. So the new firm had a capital back of it of five millions of dollars, a tidy sum in case of a storm. The firm could afford to be independent.

Unfair monopolies growled and showed their teeth. Various enemies tried various tricksmean and underhanded, tricks of trade, tricks of the market-but the farmers were not so easily taken in after all. At first they were in doubt as to whether or not they would succeed. Other firms fail; indeed, some statistician had shown that ninety-five per cent of all successful business men had failed some time or other; so they might fail. But they did not. 'Their business slowly increased. 'They adopted one 
fundamental principle; they were business men and, as business men, they had no fight upon capital. Monopolies they would fight, to the death if necessary, but organized, legitimate capital, established and administered in honesty, they welcomed as a desirable ally. Indeed, were they not in a sense capitalists now themselves?

They had no pet theories to exploit. They were not socialistic nor altruistic nor communistic ; they were not populists nor farmers' alliance men, nor grangers; they were not theorists in any degree. Individually, they might hold to any opinion they wished, but collectively, they were a plain, matter-of-fact business firm.

In the fifteen years that these farmers have now been in business, they have prospered far beyond their expectations. 'They have conquered. absolutely, every monopoly that has lifted its hand against them. 'Their actual working capital is twenty-five thousand dollars; it is never allowed to be more than this. Their total indebtedness can never be over five thousand. 'Two-thirds of the members must give their assent before any money may be borrowed, never rising above five thousand 
dollars. It is especially provided in their governing rules that "no shareholder shall sign any bond, or sign, endorse, or guarantee any note, bill, draft, or contract, or in any way assume any liability, verbal or written, for the benefit or security of any person, without the written consent of a majority of the directors." None of the funds may be loaned, under any circumstances, to anybody. There is no accumulation of tempting surpluses. The farmer is paid for his produce at the highest market. price. He buys his supplies at wholesale,flour, provisions, dry goods, a piano, what not,-plus four per cent added to cover expenses.

The firm is now doing a business of nearly, or quite, one million of dollars a year; it has never had more than twenty-five thousand dollars capital ; its running expenses, including salaries, average less than four thousand dollars a year; there are no defalcations, first, because of honesty, and second, because no surplus ever accumulates, the profits being distributed month by month. I question whether there is another firm in America, or in the world, for that matter, that can show such a volume of 


\section{THE NEW EARTH}

business on such a capital and at such a cost of administration.

Many people would like to become shareholders, but the line is drawn fast and hard. No man can join unless he is a practical farmer. The by-laws make very plain what a practical farmer is, "one who makes his living by farming, or one who has retired from the farm and is not engaged in any business that will in any way conflict with the business carried on by the company."

This firm of farmers is not bound by any speculative ties; it is not political, religious, socialistic, sociological; it is not anti-anything. It is a firm of those who produce that without which the rest of the world would die. Can it not afford to be independent?

While the influence of this body of Iowa farmers is spreading far and wide, so that other similar firms are being established, the farmers in the mass, even those who have never investigated or profited by this plan, are coming to see that independence is theirs by right,that if they wisely carry on their own affairs, they hold the key to the situation. It has taken many years for the farmer to learn that 


\section{THE IMPORTANCE OF THE FARM}

he must learn. He has come to know now that knowledge is power, and only by becoming broadly educated,-and with him his wife and his sons and his daughters,-can he hope to hold his own.

Time was, and not so very long since, either, when the most feared, because the most powerful, friend or foe the farmer had was Wall street. 'Today the great body of the West, essentially a farming body, has become absolutely independent of this powerful factor. Now and again a farmer, grown rich in his new estate, contracts the fever of speculation and is cured, or killed, by the medicines which Wall street so adroitly administers, but the mass of the western producers, recognizing legitimate uses of capital as never before, freed from the rant and cant of demagogues whose only capital is hatred of capital, have come to see that their occupation is a business in itself as much as any other; indeed, far more than this, that they maintain a great manufacturing plant, the most colossal in existence, turning out the raw material for the preservation of life itself. They have come to realize that they are the independent factors, the millions who 
must be fed, the dependents. Woe be to this world if ever the tillers of the soil adopt the tactics of some of those who control the finished products of the soil!

The commanding position of those who are engaged in the activities of the New Earth is shown in a still more emphatic manner by the magnitude to which the calling of agriculture has attained. 'The value of farm products in the United States in a year now, 1906, reaches the enormous sum of six billions, five hundred millions of dollars, a sum too vast to be comprehended. 'The report of the Secretary of Agriculture, for 1904, shows that in two years' time the farmers of this country have produced wealth exceeding the output of all the gold mines of the world since the discovery of America by Columbus. Is it too much to say that this American farmer is, by rights, independent?

In a single month of their busy season the hens of the country lay enough eggs to pay the year's interest on the national debt. In a year they produce one and two-thirds billions of eggs, enough to supply every American with two hundred and forty-five eggs a year. 



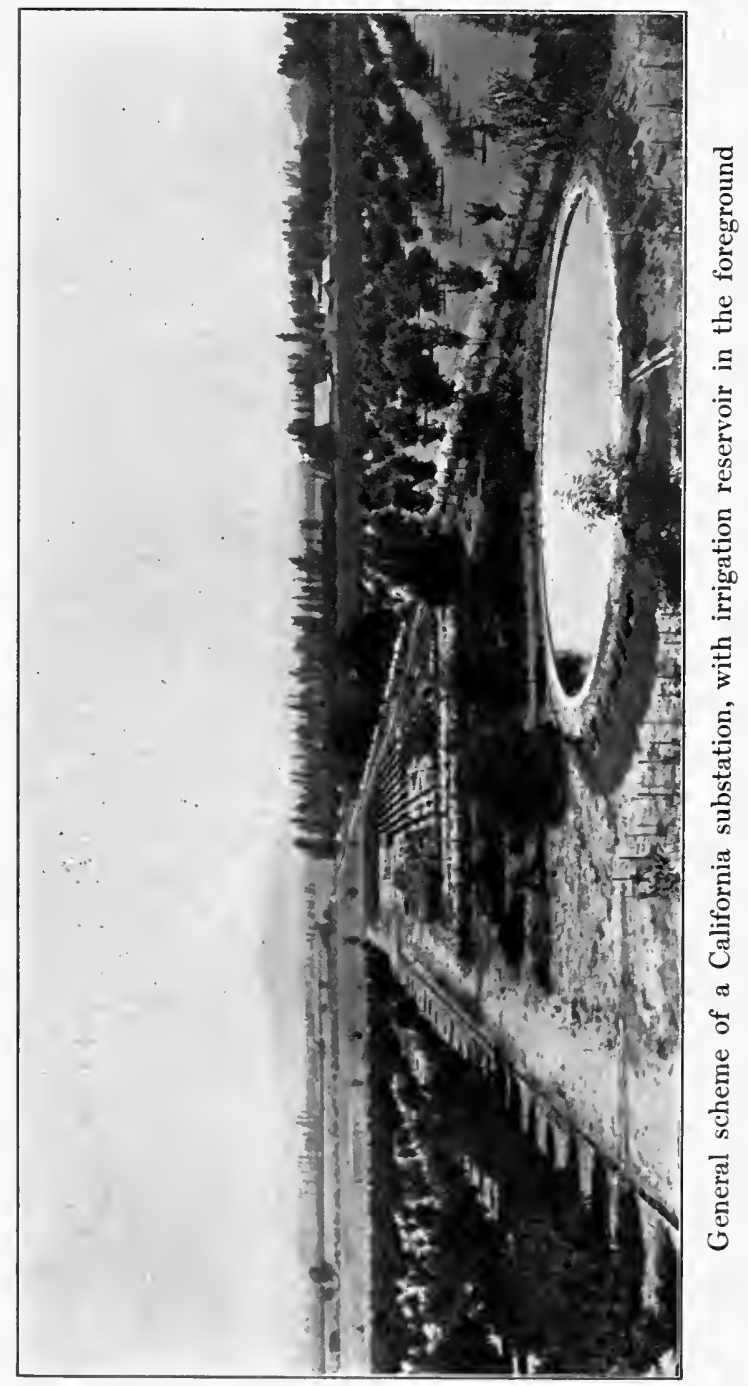




\section{THE IMPORTANCE OF THE FARM}

From the corn crop of a single year, the farmers of the New Earth can pay the interest on the national debt for a year, the entire debt itself, and a large amount of the actual expenses of the government for the year in the bargain. In 1905, the corn crop reached the highest point ever known,-2,708,000,000 bushels. Other crops in the same year were valued as follows: Hay, $\$ 605,000,000$; cotton, $\$ 575,000,000$; wheat, $\$ 525,000,000$; oats, $\$ 282,000,000$; potatoes, $\$ 138,000,000$; while dairy products reached a value of $\$ 665,000,000$, an increase over the previous year of $\$ 54,000,000$.

The products of the New Earth in the United States for two years are over six times as large as the capital stock of all the banks in America, to say nothing of the enormous capital invested in these farms. In four years, 1900 to 1904, the farms of the United States increased in value over two billions of dollars. For the five years ending with 1905, according to an estimate by the Secretary of Agriculture, the value of these farms increased at the rate of three millions, four hundred thousand dollars a day. The products of the farms for the 


\section{THE NEW EARTH}

two years 1903 and 1904, were twice the sum of all our exports and imports for a year, and three and one-half times as much as the value of all minerals produced in the country, including gold, silver, iron ore, coal and quarried stone.

Indeed, the farm of the New Earth is the colossal manufacturing plant of all history.

And the new man has learned lessons in thrift as well as in agriculture. He has learned how to keep a balance in the bank in his favor, as well as how to raise better crops and have a happier lome, and surround himself with the minor luxuries and all the comforts of modern life. 'The increase in the bank deposits in the state of Iowa, a typical western state, from June 30, 1896, to October 31, 1904, was one hundred and sixty-four per cent; in Kansas, two hundred and nineteen per cent; in Missouri, three luundred and one per cent, while the increase for the whole United States in the same period was but ninety-one per cent. In savings banks in the same period, the number of depositors in Iowa increased two hundred and nine per cent; in the United States as a whole, thirty-six per cent. In the southern 
states in 1905, bank deposits exceeded one billion of dollars, the largest ever known.

These figures, taken in connection with the value of the great plant of the American farmer, which has now reached the unthinkable sum of twenty-one billions of dollars, suggest something of the mighty power now vested in those who till the soil,-a power once put in combination capable of carrying an influence outside the sweep of the imagination.

But this is only the material side. Far beyond this lies the influence of the American farmer himself, the farmer of the New Earth. He stands out unique, the first really representative man in a calling as old as history. $\mathrm{He}$ is a menial no longer, he is dependent no longer, he is master of his own fortunes and his own destiny. And these fortunes and this destiny he looks upon clear-eyed and free from egotism.

I asked the head of one of the greatest horticultural houses in Europe, why it was that the workmen we saw about his estate seemed so uniformly gentle, so noticeably refined of face.

"It is because of the flowers and the plants," 


\section{THE NEW EARTH}

he said, "among which the men work: they make the men like themselves."

And the farm, the new farm, with its free life, its breath of the open, its close touch with nature, its hard but never menial labor, its refined home life, its articulation with all that is best in modern life, this mighty manufacturing plant of the New Earth, is turning out not only the unthinkably valuable products and steadily heaping up billions upon billions in its reserve, and maintaining at a high plane the very life of the race, but it is manufacturing men and women,-sane, symmetrical, stocked with common sense, open to higher things, receptive and retentive, untainted by speculation, and bearing a bitter hatred of the greed that not permanently, but with infinite disgrace, has fastened itself upon America.

'The farmer of the New Earth is the product of the New Earth, of its education, its enterprise, its invention, its research, its scientific investigation, its progress. $\mathrm{He}$ is, in a still deeper sense, the product of a civilization and the citizen of a Republic which, with all shortcomings, outranks all others, ancient or modern, in sweep of service to mankind. 


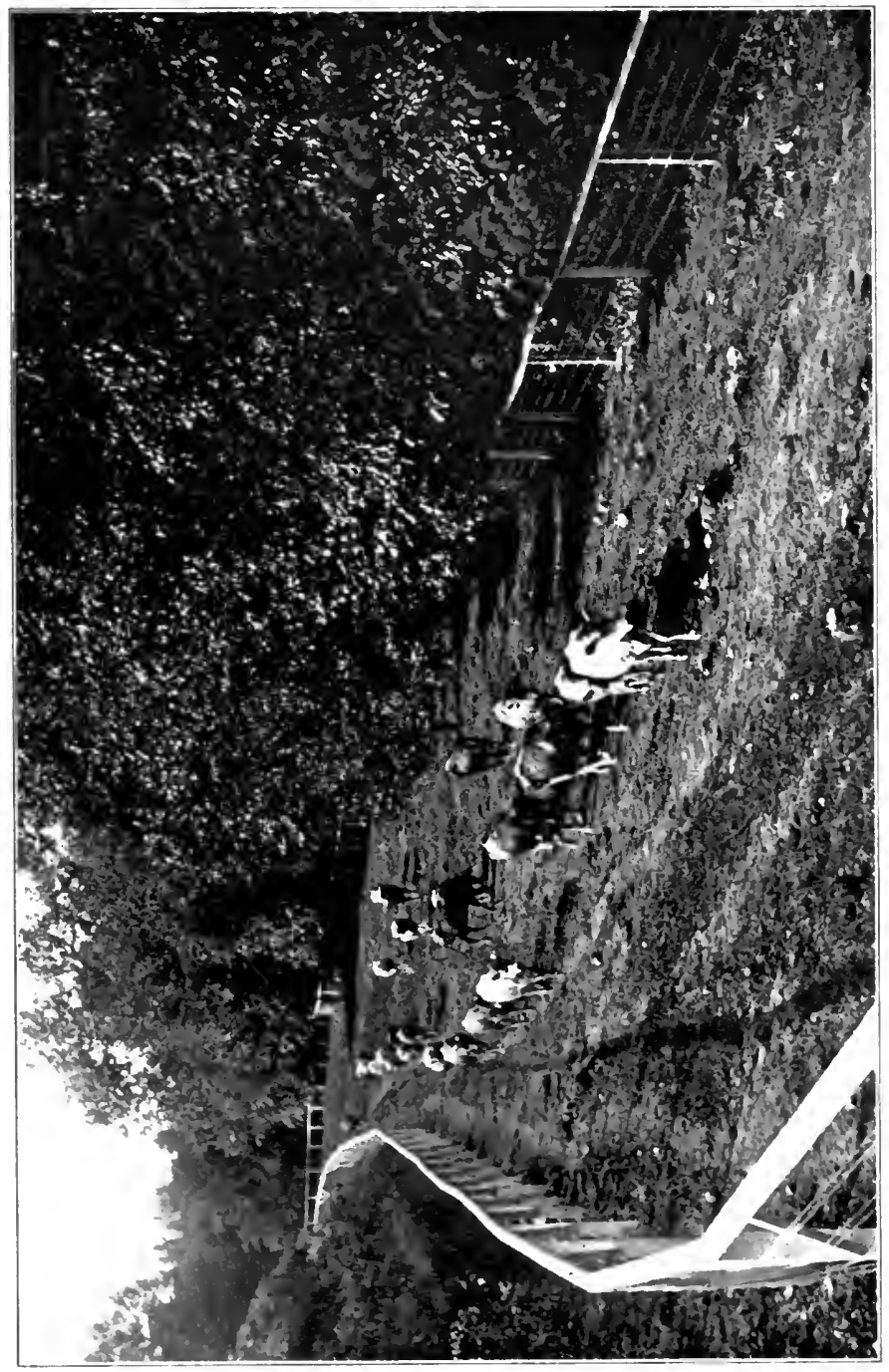

$\frac{5}{3}$ 



\section{By the Same Author}

\section{NEW CREA'TIONS IN \\ PLAN'T LIFE}

\section{AN AUTHORITATIVE ACCOUNT OF THE LIFE AND WORK OF LUTHER BURBANK}

\section{With Fifty Full-page Illustrations \\ Сloth. 12мo. \$1.75, Ner}

"Not less wonderful than the story of the thornless cactus and the seedless plum is the story of the life of the wonderful wizard of the west. The author of this book shows a great appreciation of and sympathy with the unselfish character of the man who has done so much for the world, in utility as well as beauty. His methods are explained, and many illustrations aid the text in elucidating them."-The Critic, New York.

"The first full and authoritative account of the life and work of Luther Burbank, concerning whom so much has appeared of late in American magazines, has been written by W. S. Harwood under the title 'New Creations in Plant Life.' The American reading public has shown its disposition to read with avidity everything published about this wonderful man, and we have no doubt that the present exposition of his methods will meet with popular favor. Mr. Harwood has had exceptional opportunities to familiarize himself with Mr. Burbank's remarkable work in California, and all who read his descriptions of the various aspects of the work may rest assured they are based on accurate observation authenticated by Mr. Burbank."-The Revievo of Revievs, New York.

"This volume, prepared by one who is in hearty sympathy with Mr. Burbank and who realizes some of the peculiar difficulties under which a good deal of his work is carried on, is by far the most satisfactory account we have yet seen of Burbank's successful labors."-The Evening Post. New York.

"We can recommend this volume as a truthful and readable description of a remarkable career."-The Nation, New York.

"Thousands will be interested in the full account of the man, his methods, and his successes, .. telling very enthusiastically the story of Luther Burbank and what he has done."-The Inquirer, Philadelphia.

\section{THE MACMILLAN COMPANY} 64-66 FIFTH AVENUE 


\title{
THE \\ OU'TLOOK TO NATURE
}

\author{
By L. H. BAILEY
}

Professor of Horticulture in Cornell University
Editor of "The Cyclopedia of American Horticulture," etc., etc.

Сцотн. 12mo. \$1.25, Net

"It is an instructive and enlightening volume, full of human interest, and of special value to those who have any part in the great work of education."-Toronto Globe.

"They are written in Professor Bailey's usual pleasing style, and will lead any thinking reader to a closer communion with nature."-Rural New Yorker.

"Professor Bailey's book is good reading, attractive by the simplicity of its style and the familiarity of its illustrative incidents and allusions, broadening in its teachings and helpful in its suggestions."-The Plain Dealer.

\section{A SELF-SUPPOR'TING HOME}

\author{
By KA'TE V. SAIN'T MAUR \\ Fully Illustrated from Photographs and Drawings \\ CLot1l. 12мо. \$1.75, NEv
}

"It is worth reading about, especially as the writer has a clear way of telling things that are worth telling and cannot fail to be helpful."-Minneapolis Journal.

"It is a very practical and helpful book for the amateur farmer or even for the country dweller whose gardening does not rise to the dignity of farming."-The Ontlook.

" 'A Self-Supporting Home' is both an interesting narrative and a very handy and praetical guide to life in the country on the basis of a small income. The common sense practicality, which gives the book its value, is attributable to the fact that these are actual experienees described here."-The Richmond Times-Dispatch.

\section{THE MACMILLAN COMPANY}

64-66 FIFTH AVENUE

NEW YORK 


\title{
THE CYCLOPEDIA OF AMERICAN HORTICULTURE
}

\author{
By L. H. BAILEY
}

of Cornell University, assisted by

\section{WILHELM MILLER}

And many expert cultivators and botanists

4 Vols. Over 2,800 Original Evgramiggs. Cioth. Octavo $\$ 20.00$ Net Per Set. Half Morocco, $\$ 32.00$ Net Per Set

This great work comprises directions for the cultivation of horticultural crops and original descriptions of all the species of fruits, vegetables, flowers and ornamental plants known to be in the market in the United States and Canada. "It has the unique distinction of presenting for the first time, in a carefully arranged and perfectly accessible form, the best knowledge of the best specialists in America upon gardening, fruit-growing, vegetable culture, forestry, and the like, as well as exact botanical information. . . The contributors are eminent cultivators or specialists, and the arrangement is very systematic, clear and convenient for ready reference."

"We have here a work which every ambitious gardener will wish to place on his shelf beside his Nicholson and his Loudon, and for such users of it a too advanced nomenclature would have been confusing to the list degree. With the safe names here given, there is little liability to serious perplexity. There is a growing impatience with much of the controversy concerning revision of names of organisms, whether of plants or animals. Those investigators who are busied with the ecological aspects of organisms, and also those who are chiefiy concerned with the application of plants to the arts of agriculture, horticulture, and so on, care for the names of ormanisms under examination only so far as these aid in recognition and identifcation. To introduce unnecessary confusion is a serious blunder. Professor Bailey has avoided the risk of confusion. In short, in range, trestment and editing, the Cyclopedia appears to be emphatically useful: . . a work worthy of ranking by the side of the Century Dictionary." - The Nation.

This work is sold only by subscription, and terms and further information may be had of the publishers.

\section{THE MACMILLAN COMPANY 61-66 FIFTH AVENUE NEW YORK}




\section{THE GARDEN-CRAF'T' SERIES}

Comprises practical handbooks for the horticulturist, explaining and illustrating in detail the various important methods which experience has demonstrated to be the most satisfactory. They may be called manuals of practice, and, though all are prepared by Professor BaIlEY, of Cornell University, they include the opinions and methods of successful specialists in many lines, thus combining the results of the observations and experiences of numerous students in this and other lands. They are written in the clear, strong, concise English and in the entertaining style which characterize the author. The volumes are compact, uniform in style, clearly printed, and illustrated as the subject demands. They are of convenient shape for the pocket, and are substantially bound in flexible green cloth.

THE HORTICULTURIST'S RULE BOOK. By L. H. BAILEx, 312 pp. 75 cents.

THE NURSERY-BOOK. By L. H. BAILEY, 365 pp. 152 illustrations, \$1. PLANT-BREEDING. By L. H. BAILEY. 293 pp. 20 lllustrations. $\$ 1.25$ net. THE FORCING-BOOK. By L. H. BAILEY. 266 pp. 88 illustrations. $\$ 1.00$. GARDEN-MAKING. By L. H. BAILEY. 417 pp. 256 illustrations, $\$ 1.00$. THE PRUNING-BOOK. BY L. H. BAILEY. 545 pp. 331 illustrations. $\$ 1.50$. THE PRACTICAL GARDEN-BOOK. By C. E. HUNN and L. H. BAILEY. 250 pp. Many marginal cuts. $\$ 1.00$.

\section{THE MACMILLAN COMPANY}




\section{THE RURAL SCIENCE SERIES}

Includes books which state the underlying principles of agriculture in plain language. They are suitable for consultation alike by the amateur or the professional tiller of the soil, the scientist or the student, and are freely illustrated and finely made.

The following volumes are now ready :

THE SOIL. By F. H. Kivg, of the University of Wisconsin. $303 \mathrm{pp} .45$ illustrations. 75 cents.

THE FERTILITY OF THE LAND. By I. P. ROBERTS, of Cornell University. $421 \mathrm{pp}$. 45 illustrations. $\$ 1.25$.

THE SPRAYING OF PlantS. By E. G. Lodeman, late of Cornell University. $399 \mathrm{pp}$. 92 illustrations. $\$ 1.00$.

MILK AND ITS PRODUCTS. By H. H. WING, of Cornell University. $311 \mathrm{pp}$. 43 illustrations. $\$ 1.00$.

THE PRINCIPLES OF FRUIT-GROWING. By L. H. BAILEY. 516 pp. 120 illnstrations. $\$ 1.25$.

BUSH-FRUITS. By F. W. CARD, of Rhode Island College of Agriculture and Mechanic Arts. $537 \mathrm{pp}$. 113 illustrations. $\$ 1.50$.

FERTILIZERS. By E. B. Voorhes, of New Jersey Experiment Station. $332 \mathrm{pp} . \$ 1.00$.

THE PRINCIPLES OF AGRICULTURE. By L. H. BaILeY. 300 pp. 92 illustrations. $\$ 1.25$.

IRRIGATION AND DRAINAGE. By F. H. KING, University of Wisconsin. 502 pp. 163 illustrations. $\$ 1.50$.

THE FARMSTEAD. By I. P. ROBERTS. 350 pp. 138 illustrations. \$1.25.

RURAL WEALTH AND WELFARE. By GEORge T. FAIRCHILd, Ex-President of the Agricultural College of Kansas. 381 pp. 14 charts. $\$ 1.25$.

THE PRINCIPLES OF VEGETABLE-GARDENING. BY L. H. BAILEY. $468 \mathrm{pp}$. 144 illustrations. $\$ 1.25$.

THE FEEDING OF ANIMALS. By W. H. Jordan, of New York State Experiment Station. 450 pp. $\$ 1.25$ net.

FARM POULTRY. By Ggorge C. Watson, of Pennsylvanla State College. 341 pp. $\$ 1.25$ net.

THE FARMER'S BUSINESS HANDBOOK. By I. P. ROBERTS, of Cornell University. $300 \mathrm{pp}$. $\$ 1.00$ net.

THE CARE OF ANimals. By Nelson S. Mayo, of Kansas State Agricultural College. $458 \mathrm{pp}$. $\$ 1.25$ net.

THE HORSE. By I. P. ROBERTS, of Cornell University. \$125 net.

New volumes will be added from time to time to the Rvral. Sciexce Series. The following are in preparation.

PHYSIOLOGY OF PLANTS. By J. C. Arthur, Purdne University.

THE PRINCIPLES OF' STOCK BREEDING. By W. H. BREWER, of Yale University.

PLANT PATHOLOGY. By B. T. Galdoway and associates, of U. S. Department of Agricnlture.

The POME FRUITS (Apples, Pears, Quinces). By L. H. Bailex.

\section{THE MACMILLAN COMPANY 64-66 FIFTH AVENUE NEW YORK}




\title{
CYCLOPEDIA OF AMERICAN AGRICULTURE:
}

\author{
Edited by PROF. L. H. BAILEY
}

of Cornell University, Editor of "Cyclopedia of American Horticulture": author of "Plant Breeding "; "Principles of Agriculture," etc.

With 100 full-page plates and about 2,500 illustrations in the text

\section{TENTATIVE SYNOPSIS OF CONTENTS \\ VOLUME I}

Part I-General Considerations-Agricultural Regions-Farm IndustriesLayout of Farm-Equipment and Capital Required-Farm BuildingsFarm Water Works-Farm Machinery-Adornment of Farm Prenises.

Part II-ClimatologY-General Definition and Scope-Atmosphere-Temperature-Pressure-Cireulation-Atmospheric Moisture-Storms-Prccipitation-Weather-Climate.

PART III-THE Soll-General Considerations-Origin and Formation-Kinds and Characteristics-Properties-Germ Life in the Soil-Moisture-Tillage-Fertilizers-Waste and Renovation-Soil Surveys,

\section{VOLUME II-FARM CROPS}

Part I-Plant Production-The Plant-Environment-Plant Improvement - Farm Management-Plant Introduction-Classifications-Industries.

Part II-Individual Farm Crops (suggested treatment)-General-Geographical Distribution and Extent-Propagation and CultivationVarieties-Harvesting and Preservation-L'ses and Preparation for UseManufacture-Obstructions to Growth-Marketing-Exhibiting-Tools - History,

\section{TIMBER CROP (FARM WOODLOT)}

Introductory-Factors of Forest Production-Methods of Forest GrowingSystems of Forest Cropping-Improving and Caring for Crop-How to Treat a Mismanaged Woodlot-Uses of Different Woods-Home Utilizition of the Crop-Measuring and Marketing Forest Crops.

\section{VOLUME III-FARM STOCK}

Parit I-Gfaneral Principles-Introduction-Kinds of Animals-Kinds of Animal Industry-Origin and Breeding of Domestic Animals-Pliysiology-Feeding-Hygiene, Santation and Management.

Part II - OUtline for Treatment of Diffellent Kinds of Animals-Gineral Introductory Discussion-Distribution and Extent-Classification of Breeds and Types-Breeding-Feeding and Feeds-Management and Hygiene-Products-Diseases and Disabilities-Judging and Scoring Marketing-Exhibiting-Iistory.

Part III-Animal Industrifs or Tecinology-Dairying-Dressing and Curing of Meats-Storage-Refrigeration-Fertilizer Manufacture.

\section{VOLUME IV}

The Fakj anp the Community (Economics, Social Questions, Organizations, History, Literature, etc.)

Full prospectus with sample pages sent tree on application

The Macmillan Co., 64-66 Fifth Ave., New York 

This book is DUE on the last date stamped below

\section{JUN 11 195?'}




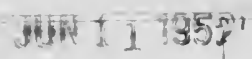

$$
\begin{gathered}
S \\
521 \\
H 26 \pi \\
\text { cop. }
\end{gathered}
$$


I. m. m. 